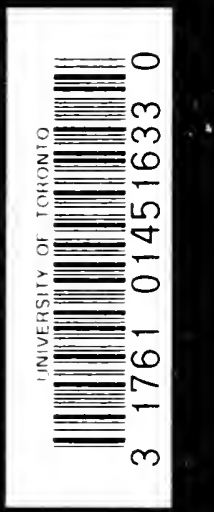





\section{War Story of the Canadian Army Medical Corps}


Digitized by the Internet Archive in 2007 with funding from Microsoft Corporation 


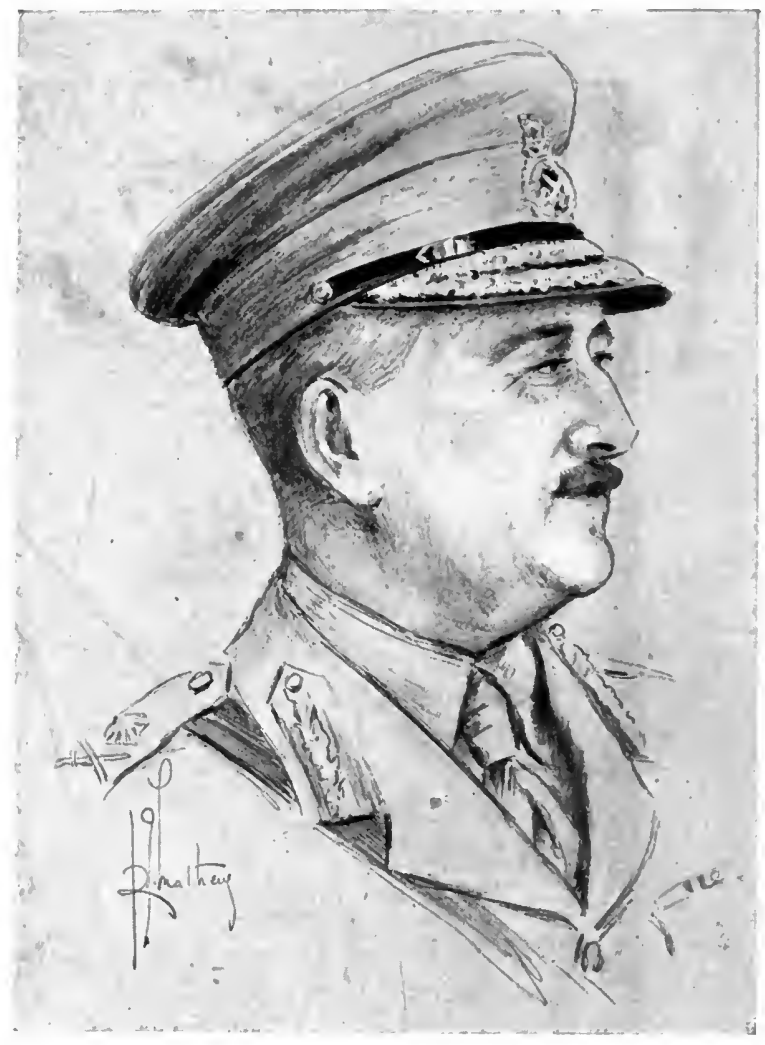

Major-General G. L. Fuster, C.B., Director General Medical Surrices, Orerseas Military Forces of Canada. 


\section{War Story of the}

\section{Canadian Army Medical Corps}

\section{BY}

J. GEORGE ADAMI, M.D., F.R.S.

(Temporary Colonel C.A.M.C.)

A.D.M.S. in Charge of Records, Office of Director.General. Medical Services, O.M.F.C.

\section{Volume I.}

THE FIRST CONTINGENT

- (to the Autumn of 1915) -

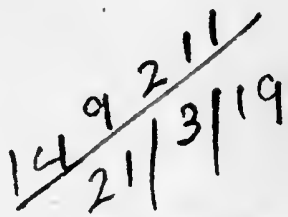

PUBLISHED FOR THE CANADIAN WAR RECORDS OFFICE BY

\section{COLOUR LTD.,}

33. VICTORIA STREET, WESTMINSTER, S.W. AND

THE ROLLS HOUSE PUBLISHING CO. LTD. BREAM'S BUILDINGS, FETTER LANE, E.C. 


$$
\begin{aligned}
& D \\
& 629 \\
& C_{2} A_{6}
\end{aligned}
$$

v.l 


\section{INTRODUCTION}

BY

THE RT. HON. SIR ROBERT L. BORDEN, G.C.M.G., P.C., ETC., PRIME MINISTER OF CANADA

To some the call of adventure, to others the fighting spirit of the race, but to most the duty of service appealed. Fresh from the avocations of peace and untrained at first in the art of war, they went forth strong, joyous, eager, confident. Valour and heroism were never more truly symbolized than in the story which their deeds have given to the world.

Such was the spirit of the Canadians in the battle line as $I$ have seen and known them. One could not return from such a visit without renewed courage and strengthened determination. From the wounded in the hospitals one gained at least an equal inspiration in witnessing many a triumph of the spirit over the dull pain and monotony of long, weary months.

Let the Nation also give its tribute to those who consecrated their service to the care of the wounded; to the men who went forward through the battle storm with bullet-spattered ambulances to rescue those who had fallen; to the women whose first thought was of the helpless and suffering, when hospitals were bombed.

It is fitting that the story of the Canadian Army Medical Service should be told; and no one is more qualified for that purpose, whether by experience, by service, or by the truest ideal of duty, than he who has written the pages that follow.

I6th August, rgr8. 



\section{PREFACE:}

AN attempt is here made to record the outstanding facts bearing upon the activities of the Canadian Medical Service in such a form that the general reader may realize and become interested in the part played by medicine and surgery in modern warfare, while at the same time the professional reader may be given, as it were, a bird's eye view of the progressive development of military medicine in the great war as exemplified by the work of the C.A.M.C. How far the attempt has succeeded the reader must judge.

Based as the work is upon the official documents and the diaries of individual Medical Officers, the writer is only too well aware of its deficiencies. Official documents are apt to be painfully meagre in regard to the very matters which the historian needs for a full presentation of any particular happening: they may at times be wholly wanting. The Officer in the position to give the fullest details may constitutionally be unwilling to set pen to paper: may put down a line or two of bald official data, when for the credit of his unit and the officers and men under him, he should have set forth a detailed statement of events; on the other hand, some officer concerned in actions of subordinate importance may note these so clearly and interestingly that perforce the historian quotes at length from his description. If, therefore, too full credit is given to certain units and individuals, too little to others, the fault must to no small degree be attributed not to the historian, but to the material at his disposal. So also the limits set to the size of the volume have limited the publication of operation orders and the minutiæ of movements and activities of individual units. 
The work will be of distinct service if, by calling attention to defects in the official records and that at a time not too distant from the events, it gives occasion to those actually concerned to afford the needed information and so prepare the way for a fuller and more accurate presentation of the facts at a later date. What has impressed the writer is the difficulty in securing accurate information even within a few months of the event: the difficulty, therefore, that must confront the historian who writes years after the event: the value of such a "contemporary history" as demonstrating to the officers in charge of units the importance of keeping adequate War Diaries.

So many of his colleagues have aided him that the writer finds it invidious to mention their names. He has studiously endeavoured throughout to acknowledge the sources of his information. One essential source has, however, been left out, and he would here call attention to the fact that for events in France as they affected the C.A.M.C. the underlying basis of his work has of necessity been the War Diary and reports of the A.D.M.S., First Canadian Contingent, now MajorGeneral Foster, D.G.M.S. To General Carleton Jones and Colonel Lorne Drum he is indebted for much of the information upon which has been based the chapter upon the rise of the C.A.M.C.

London, August, I9I8. 


\section{CONTENTS}

CHAP.

PAGE

INTRODUCTION

I.-RISE OF THE C.A.M.C. $\checkmark$ • • • II

II.-The ASSEMbly at VALCARTIER, AND THE

CROSSING . . . . . . $\quad$. 36

III.-SAlisbuRy Plain • $\quad$ • $\quad$ • $\quad$ • $\quad$ - 57

IV.-With the B.E.F., France $\checkmark . \quad$. . 79

V.-The Second Battle of Ypres: the

Onset; Poison Gas $\checkmark$. . . 97

VI.-The Second Battle of Ypres con-

TINUED : THURSDAY AND FRIDAY • III

VII.-The Second Battle of Ypres con-

TINUED: Saturday aNd SUNDAY $\quad 133$

VIII.-The Second BATtLe of YPRES: con-

CLUDED • . . . . . I5I

IX.-FESTUBERT • • • • • .

X.-Givenchy . . . . . . 204

XI.- "Plugstreet" . . . . . . . . 213

XII.-Hospital UNITS AND THEIR Establish-

MENT IN FRANCE: THE GENERAL

Hospitals.` . . . . . 232

XIII.-Hospital Units : StationaRy Hospitals $/ 256$

XIV.-Other Medical Units on the Lines of

COMMUNICATION

272 


\section{LIST OF ILLUSTRATIONS}

Major-General G. L. Foster, C.B., Director-

General Medical Services, Overseas

Military Forces of Canada . . . Frontispiece

Salisbury Plain . • . . Facing P. 57

Northern Sector of Ypres Salient, Medical

Disposition, April 2Ist, r9I5 " $\quad 99$

Forenoon of Friday, April 23rd . . " " 124

Evening of Saturday, April 24th . . " , 133

The Shortening of the Line: Position on

April 22nd and May 4th . . . . 160

Medical Disposition, May 22nd $\quad$ Facing P. $\quad$ I84

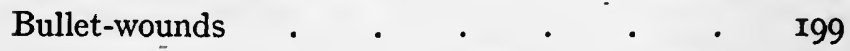

North of the Aire-La Bassée Canal Facing p. 206

Admission tent.$\quad$. $\quad . \quad$. 250

No. I Canadian Stationary Hospital,

West Mudros . . . . . . 26r

Bailleul, Kemmel and Ploegsteert Area Facing p. 286 


\section{WAR STORY OF THE C.A.M.C.}

\section{CHAPTER I}

THE RISE OF THE C.A.M.C.

$\mathrm{W}^{\mathrm{E}}$ are apt to forget how intimately the Army and the Army Medical Service are associated with the medical history of the Dominion. But so it is. For sixty years and more after the conquest, Canada was too poor and too thinly populated to be able to establish and support medical schools, or to attract well-trained doctors, either from the old country or from the States to the south. As a result, the surgeons who came over with the British regiments found their services in such request that many of them elected to remain when their regiments were recalled, and in all the older centres of population we meet with the same story: these old Army doctors became the recognized heads and leaders of the profession. Their connection with the Service gave them an immediate standing in the young community. They brought with them the old-world ideals of professional conduct, ideals strengthened, and indeed raised, by their military training and associations; and, as Major-General Fotheringham has well pointed out,* it is largely owing to their

* British Medical Journal, October 13th, 1917 ; II., 471. 


\section{WAR STORY OF THE C.A.M.C.}

influence that Canada has escaped the haphazard legislation, defective training and irregular medical practice which have cursed so many of the States of the Union to the south. When at last the population had increased sufficiently to maintain and justify the establishment of medical schools, we find that in Lower Canada two out of the four founders of the Montreal General Hospital and of the Medical School which in a few years became the Medical Faculty of McGill College, were old Army doctors; that another Army surgeon, Widmer, "scrupulously punctilious, and in every detail regardful of the proprieties of life,"* was the father of the profession in Upper Canada; a man of the very highest character, who did more than anyone else to promote the progress of the profession in what is now Ontario. Similarly in Acadia it was the old Army doctors, who in 1783 came along with the ship-loads of loyalist fugitives from the south, and formed the mainstay of the profession, while later, the British regiments at Halifax and elsewhere provided for two generations the foremost practitioners of Nova Scotia, and of New Brunswick; when in $\mathrm{I}_{784}$ this was separated as a distinct province.

It is difficult for us, after fifty years of confederation, to realize that before that event there was no Canada proper, but a collection of separate provinces, which with difficulty had obtained something more than the status of Crown Colonies. So long as the Mother Country with its troops garrisoned and protected these, there was no urgent need for provincial militia. Militia regiments

* Sir W. Osler, Address in Medicine, Montreal Meeting of the British Medical Association, 1897. 


\section{RISE OF THE C.A.M.C.}

there were, it is true, here and there, but these existed more for ceremonial than for practical purposes; and their medical organization was the outgrowth of pre-Napoleonic conditions, when the regimental medical officer was still looked upon, along with the chaplain, as, if not the servant, certainly the nominee of the colonel of the regiment. Organized medical service was wholly wanting.

With Confederation, in 1867 , the removal of the British troops necessitated that the new Dominion take some steps to establish a military system for itself. But it has to be acknowledged that Canada was not in a hurry to become a military power. It looked forward to a long era of peace. Can there be more striking evidence of the essentially pacific nature of the Anglo-Saxon peoples than the fact that the long-drawn line of boundary between the United States and Canada has no patrol ? It was in June, IgI4, a few brief weeks before the war, that the English speaking peoples celebrated the completion of a century of peace among themselves. We speak of the long frontier of some eight hundred miles that Russia had to protect against Germany and Austria: what is that to the three thousand miles of the Canadian frontier? Thus the Canadian Militia grew somewhat slowly. The Mother Country was most considerate; for strategic reasons it retained Halifax and Esquimalt for some forty years, until, under Admiral Fisher's naval scheme, Halifax, Esquimalt, Bermuda and St. Lucia were no longer employed as naval bases. As militia regiments were raised in each province, each had its surgeon-major chosen from among the local practitioners, but there was no Army Medical Service proper ; nor was any course of preliminary instruc- 
tion required for those who became Regimental Medical Officers. Gradually a small permanent medical force developed. Certain permanent military units had to be established at what may be termed strategic points-at Quebec, Kingston, St. John's, P.Q., Winnipeg, etc., and with the garrisons came the need for military hospitals and their personnel. In this way it came about that certain local practitioners obtained appointments over long years as medical officers to these garrisons, attending to the troops in addition to their private practice; but these rudiments of an Army Medical Service were for a generation so inconsiderable that there was no Director-General or Headquarters Medical Staff at Ottawa.

The Riel Rebellion in 1885 afforded Canadians their first independent experience of warfare since the campaign of 1812 (the Red River Expedition of September, 187o, was under British leadership ; the Fenian Raid of 1875 was abortive and may be neglected) ; and here, while giving all credit to all actively engaged, it has to be confessed that the Medical Service was crude. There had been little or no preliminary organization. With the raising of the Field Force, it became essential to appoint a staff of medical officers. Dr. Bergin, M.P., of Cornwall, Ontario; was appointed Surgeon-General at Ottawa, there to control the medical branch and advise the Minister of Militia ; Dr. (now Sir Thomas) Roddick, of Montreal, was made Deputy SurgeonGeneral, and directed to proceed at once to Qu'Appelle in the north-west and establish hospitals in such localities as the General in charge might designate; Surgeon-Major Douglas, V.C., who had been in the Imperial Service and on retirement had 


\section{RISE OF THE C.A.M.C.}

settled in Halifax*, was appointed Director of the Ambulance Corps; Dr. (later the Honourable M.) Sullivan, Professor of Surgery in Queen's University, Kingston, was Purveyor-General; Dr. James Bell (later Professor of Surgery, McGill University) was appointed Surgeon, to take charge of one of the hospitals (the Field Hospital with General Sir F. Middleton's Division), and under him were six assistant surgeons; these in addition to the Regimental Medical Officers attached to each regiment, and a number of Toronto and Montreal medical students, who volunteered to go to the front as hospital dressers. There were only between four thousand and five thousand troops actively engaged in the field, and the preparations, therefore, had to be on a much smaller scale than we have become accustomed to in the great war. The campaign was conducted, it will be remembered, in a virgin country during the spring and early summer months, so that the amount of sickness was inconsiderable; there was an entire absence of typhoid, malaria and dysentery ; even diarrhœa was almost unknown. Nor was the number of wounded such as to overtax the hospital accommodation provided at Saskatoon, Battleford and elsewhere. In other words, despite their lack of previous experience or previous training, the Medical Service rose to the occasion, which fortunately did not, medically speaking, become grave.

Following this little campaign there were those who urged the reorganization of the Service, with a Surgeon-General at Ottawa and Deputy Surgeon-

- He there married Mrs. MacMaster, the widow of anothor British Medical Officer and V.C. 


\section{WAR STORY OF THE C.A.M.C.}

General and staff in each province; but nothing was accomplished for many years to come, save that Dr. Bergin remained titular Surgeon-General, and three Deputy Surgeons-General were appointed : Drs. Roddick (Montreal), Ryerson* (Toronto) and Tobin (Halifax). But these all continued their civil practice, as did the whole service. The Regimental Medical Officers, it is true, were there, chosen by the officers commanding each militia regiment, and gazetted in due course as Surgeons-Major: that rank they retained whatever the length of their service. Not a few believed that they were ornaments to their regiments, and that they fulfilled all that in decency could be demanded of them if they appeared, in a uniform becoming progressively tighter, at each annual church parade. The only active members of the force were the semi-permanent officers, the local practitioners attached to the garrisons ; these were, in general, appointed Principal Medical Officers at the annual camp of the

- Of the three these two still survive. It is, indeed, a question whether Sir Thomas Roddick and Dr. Ryerson were ever gazetted out, and whether they are not still Deputy Surgeons-General. Sir Thomas Roddick, as late M.P. for the St. Antoine division of Montreal, and President of the British Association upon the occasion of its first visit to Canada, is widely known as the father of the "Roddick Bill," whereby practitioners registered in one Province can gain entry to practise throughout the Dominion. Dr. G. A. S. Ryerson is another well-known Canadian, who served in the Fenian Raid in 1875 , and becoming surgeon to the Royal Grenadiers, Toronto, served with them in the NorthWest Rebellion. As Canadian Red Cross Commissioner he participated in the South African war. Besides being General Secretary of the St. John Ambulance Association for Canada he in 1896 played a prominent part in founding the Canadian Red Cross. The Quarterly Militia List for the Dominion, while recording his appointment as Hon. Colonel in January, 1917, admits also his rank (in brackets) of Hon. Surgeon-General. 
district, and, as such, gave courses of instruction. There was, in fact, little or no organization. Between camps the permanent medical officers had no control over the regimental medical officers. Medical equipment for the annual camps, preserved between times at the District Medical Stores, were, to say the least, meagre.

This state of affairs persisted until 1896 : until, that is, it so happened that a medical man, the late Sir Frederick Borden, became Minister of Militia. In this year a definite Medical sub-department of the Militia was created, with a Director-General at its head, having his headquarters in Ottawa. From 1896 dates thus the development of the Canadian Army Medical Corps. The first DirectorGeneral was Colonel Hubert Neilson. John Louis Hubert Neilson had not a little army experience. Born in Quebec in 1845 , he received his training at the Army Medical School, Netley, and in 1869 became Medical Officer of the Quebec Garrison Artillery. He saw service during the Fenian Raid; acted as a Red Cross Surgeon in the Russo-Turkish war of 1878 ; was surgeon to the Canadian "voyageurs," called by Sir Garnet Wolseley after his Red River experience to aid in the Soudan campaign of $1884-85$; was attached to the British Army for two years, making a tour of Europe and the United States to study army medical organization. Being largely independent of his practice, he accompanied his unit, the Garrison Artillery, when it was ordered elsewhere-to Victoria and Kingston. It was from Kingston that in 1898 , after this preparatory study of army medical organization elsewhere, he was called to Ottawa as D.G.M.S. Here his headquarters were 


\section{WAR STORY OF THE C.A.M.C.}

constituted by railing off the end of a corridor, and in this simple improvised room a single cupboard of no great size was sufficient to contain all the reserve stores of the Service!

But here was a beginning along modern lines, and the first important action of the D.G.M.S. was to take advantage of the carefully-thought-out new organization of the Royal Army Medical Service. $\mathrm{He}$ had himself already been attached to the R.A.M.C. at Aldershot, and now he persuaded the minister to send him, and with him several medical officers, to England, to follow courses of instruction there and thoroughly familiarize themselves with the working of the R.A.M.C.*

The officers so trained were to be utilized as instructors of the new Canadian Medical Service which Colonel Neilson proposed to form. Lieutenant G. C. Jones had already been concerned in an important innovation, namely, in the formation of the first Canadian Bearer Company after the British model. This was before the Field Ambu. lance, as at present constituted, had been developed. The establishment of the Bearer Company arose out of an agreement with the Imperial authorities, whereby the Canadian Government supplied the medical personnel for the Halifax garrison and

* Among those Medical Officers who in this way first underwent a full course of training at Aldershot and in London were the present D.G.M.S. Overseas Military Forces of Canada, Major-General G. L. Foster, C.B.; the late D.M.S. Canadians, General G. Carleton Jones, C.M.G.; Majors Nattrass and Belton, of the Royal Canadian Rifles; Major J. D. Brousseau, of the

Field Battery at Quebec and Major H. S. Birkett, C.B., of Montreal, until 1918 Colonel in command of No. 3 Canadian General Hospital, and at home Dean of the Medical Faculty of McGill University. 


\section{RISE OF THE C.A.M.C.}

kept it at war strength, Great Britain supplying the equipment and Canada finding and supporting the officers and men.

Then in the autumn of 1899 Colonel Neilson drafted an all-important Order in Council, which was duly promulgated. Authority was granted by this for the formation of an Army Medical Corps consisting of six bearer companies and six field hospitals. The officers of the Corps were to be arranged in due Army order, were to hold substantive rank, and to receive promotion by seniority as vacancies should occur. The order recognized the regimental officers already existing, and formed these into a Regimental Medical Service, to include all medical officers appointed to regiments. These officers were to receive promotion not by seniority but by length of service, and to rise from the rank of lieutenant to that of major. It detailed, further, the relationship of the two services-the Army Medical Corps and the Regimental Medical Servicein the event of mobilization, and, what was of fundamental importance, laid down a course of instruction for those seeking to qualify as medical officers.

During the winter of 1899 and 1900 the DirectorGeneral visited the various main centres throughout Canada, explaining the scheme and calling for volunteers for the new Medical Corps with good success. The bearer companies were classed as " city units," and, in addition to their training during the winter in the armouries, were required to do three days' training in camp. The Field Hospital units were classed as "rural units"; they underwent twelve days' training in camp.

When, in September, I899, the Boer War broke 


\section{WAR STORY OF THE C.A.M.C.}

out and Canada spontaneously offered her First Contingent, the organization of the Medical Corps had not proceeded sufficiently far for the Dominion to send with it anything beyond the Regimental Medical Officers, and, it should be added, the regimental stretcher-bearers which were supplied from the personnel of the Halifax Bearer Company, the only body of trained orderlies in the Dominion. This was not due to the fact that the officers and men were lacking, but that organization was still far from complete. As a matter of fact, Canada did not send a division. It was merely an infantry battalion which composed the First Contingent to South Africa. After the departure of the First Contingent from Quebec, on October 3Ist, I899, three Field batteries and two battalions of Mounted Rifles (the Ist C.M.R. and the R.C.D.) were enlisted, sailing in January, I900, and in March the Strathcona Horse followed, and were succeeded later in the year by $a$ large draft of Canadians to join the newly-established South African Constabulary (fashioned after the type of the famous North-West Mounted Police). But it was only in January, I902, some six months before the end of the war, that the first Canadian medical unit, the roth Canadian Field Hospital, was ready to leave Halifax, with the late Colonel A. Norris Worthington, M.P. for Sherbrooke, in command.* The equipment differed from that of the regulation British field hospital in that it was a combination of British and American

* The Staff was as follows : Colonel A. N. Worthington, in command; Major G. Carleton Jones, second in command; Captain H. G. Johnson ; Lieutenant J. A. Roberts (now Colonel, C.B., later O.C. No. 4 (University of Toronto) General Hospital ; now A.D.M.S. Canadians, London area); Lieutenant P. Weatherby ; Quartermaster, Lieutenant H. V. Tremaine. 


\section{RISE OF THE C.A.M.C.}

usages. The Hubert tent (so-called after Colonel Hubert Neilson, who devised it) replaced the British hospital tent, and the wagons were lighter than the British model, being built upon the lines of a Canadian express" wagon. It carried with it another innovation of Canadian origin-namely, a mobile acetylene gas plant.* Arriving at Durban, Natal, in February, the unit trekked up country through Laing's Nek and across the Orange Free State to the Transvaal, until it reached Valbank, where the larger part of the unit, under Colonel Worthington, became established as a stationary hospital, and, as such, was an important medical factor in the final decisive operations of the war. Under the command of Major G. C. Jones, a detachment became a mobile unit with Cookson's column in General Walter Kitchener's force on "trek," and took part in the operations in the Transvaal and Northern Cape Colony. This detachment never rejoined the unit, but had the good fortune to be present at the Battle of Hart's River or Buscbolt, along with the 2nd C.M.R. A bulletmarked Red Cross pendant from one of its ambulance wagons remains as a relic of this engagement in the office of the Director-General at Ottawa.

The Regimentai Medical Officers saw abundant service. Three had accompanied the First Con-

* The acetylene gas plant, it must be remembered, is a Canadian, not to say Ottawa, invention. Lieutenant-Colonel Whitton (now O.C., H.M.H.T. Araguaya) reminds me that in South Africa, in comparison with the few lamps in other buildings and tents, the roth Field Ambulance was so brilliantly lighted, and could be seen from such a distance, that it was commonly made the location point by which individuals and bodies of troops steered themselves. 


\section{WAR STORY OF THE C.A.M.C.}

tingent, but only one-Captain Eugene Fiset* (of Quebec)-was present with the battalion during the greater part of its service in the field. Joining the contingent as Junior Medical Officer at the last moment before it sailed, he remained with it during its whole service, save when he was a prisoner. $\mathrm{He}$ received the D.S.O. for distinguished service at Paardeburg, an honour which also was gained by Major Keenan $\uparrow$ (of Montreal) of the Strathcona Horse.

When, in June, I902, the war came to a sudden end, preparations were made to hold a training camp in the autumn. As can easily be grasped, the war exposed the weak points in the militia medical system, and active efforts were made to remedy deficiencies. There was still no proper provincial or district medical organization; where there was stationed a permanent unit, its -Regimental Medical Officer had been the natural channel through which the Director-General kept in touch with local needs. There were, however, large districts with no permanent units, and therefore with

* Sir Marie Joseph Eugene Fiset, C.M.G., D.S.O., son of the Hon. I. B. R. Fiset, was born at Rimouski, Quebec, in 1874. A graduate of Laval University, his army service dates from 1890, when he became attached as Second-Lieutenant to the 89th Regiment; Major, 1898; Brevet Lieutenant-Colonel, 1901 ; Lieutenant-Colonel, 1903; Colonel (P.A.M.C.), 1904. He served in the South African war 1899-1902, and was present at operations in the Orange Free State and Eastern and Western Transvaal. Three times mentioned in Dispatches, he possesses the Queen's Medal with four clasps, and was awarded the D.S.O.; P.M.O. with the Coronation Contingent, 1902; Staff Adjutant, 1902-3 ; D.G.M.S., 1903-6 ; Deputy Minister of Militia and Defence, 1906; Surgeon-General, 1914; knighted, 1917; Knight of the Legion of Honour.

† Now Lieutenant-Colonel. In this war M.O. to the "Princess Pat's" during the first year, and, later, Senior Surgical Officer to No. 2 Canadian General Hospital. 


\section{RISE OF THE C.A.M.C.}

no local heads. Now a move was made in the first place to change this, and appoint Principal Medical Officers, who should supervise the medical units of their districts and keep Headquarters informed regarding matters of personnel and equipment. Subsequently on the formation of commands P.M.O.'s were appointed to the commands and Senior Medical Officers to the districts. After the war Lieutenant-Colonel Fiset, D.S.O., had taken a course of instruction with the R.A.M.C. Upon his return in I902, he was appointed Staff Officer to the D.G.M.S., succeeding LieutenantColonel Neilson as Director-General, when the latter officer retired in Igo3.

Experience in South Africa had led the Imperial authorities to combine the old bearer company and field hospital into one unit, the Field Ambulance. The object of this step was to attain increased mobility at the front, and more particularly to combine under one command the two intimately related functions of collecting the wounded and affording immediate but temporary care of the same. It is interesting to note how, as the great war progresses and the scale of operations becomes increasingly vast, there is a tendency of necessity to resort to the old separation of these two functions; but undoubtedly, by the extent and variety of the duties imposed upon it, the Field Ambulance has become a most attractive and excellent training ground, affording a wider experience than does any other unit. The old Bearer Company, as the "Bearer Section," still remains as the basis of the new organization; the Field Hospital is represented by the "Tent" and transport sections, but, shorn of its iron cots and heavy 


\section{WAR STORY OF THE C.A.M.C.}

marquees, it has become more mobile, capable now of rapid movement. How necessary is this ease of movement has been abundantly demonstrated in this war, when one day a Field Ambulance may be running two or more Advanced Dressing Stations close to the trenches, the next day a Main Dressing Station three or four miles back of the line, and the third a Divisional Rest Station at "the back of the front." The first move of the new D.G.M.S. was to introduce the Field Ambulance unit into the Canadian Service, and this, not by combining rural " hospital" and city "bearer" units, but by expanding each of these units wherever possible into a full ambulance unit.

This expansion was of set purpose. The British Field Ambulance called for ten officers and $24 \mathrm{I}$ other ranks, of whom sixteen were to be noncommissioned officers of the rank of sergeant or higher. Colonel Fiset, in the Canadian establishment, called for the same number of officers and N.C.O.'s, but for only seventy-five other ranksi.e., one-third the number. Where the British organization consisted of three sections, the Canadian provided but one full section, with the skeleton of the other two; the idea being that upon mobilization it would be easy to recruit the rank and file to full strength, and that here was a means of inducing the maximum number of civil practitioners to accept commissions and interest themselves in the Service. This policy has fully justified itself.

In the same year (I904) the officers and personnel of the permanent medical service were definitely banded together into a corps-the P.A.M.C.

To Colonel Fiset also belongs the credit of initiating 


\section{RISE OF THE C.A.M.C.}

the first movement in the direction of a wellordered modern camp sanitation. The present war has proved most conclusively that the preventive and hygienic functions of the military medical service are of greater importance than the purely medical functions. But it has taken long years to dissipate the old idea that, a camp being only a temporary abode, filthy surroundings had to be put up with; and that if, as was noted in the Crimea for example, a horse happened to die in the lines, it might lie there and pollute all its surroundings, it being nobody's business to remove it. And Colonel Fiset began with the "slop sink." Until I904 the removal of kitchen waste in camps was of the crudest. Pits were dug close to the cookhouse, and into these were dumped the kitchen refuse, fluid and solid. The refuse, exposed to air and sun, soon stank, and as one pit filled up it was replaced by others equally unsavoury, fly-infested and fly-blown. The D.G.M.S. showed that this nuisance could be effectually removed by pouring all the refuse into a box provided with holes in the bottom and a movable top, placed over the intersection of two cross trenches; the fluid drained into the trenches, and when the box became full, all that was necessary was to burn the contents in the kitchen fire. To Colonel Fiset, in short, is due the credit of having impressed upon the medical officers the fact that camp sanitation is more than a quartermaster's duty. It took some years, however, to impress this upon the camp authorities and regimental commanders, who, regarding the medical officers as " cure doctors" and not as "prevention doctors," held that their duties began after the series of sanitary defences had broken down 


\section{WAR STORY OF THE C.A.M.C.}

and the men fell ill. Regarding sanitary matters as belonging entirely to the (lay) quartermaster, they were apt to regard recommendations by their medical officers concerning matters of hygiene as a rank intrusion, and to turn them down as a matter of principle. Remember that we deal here with the state of affairs as they were little more than a dozen years ago. Our camps were sanitary blots, nuisances which the old-timer in the militia, with nose and stomach hardened to the conditions, regarded as necessary evils. But already at this period the lines of the medical units, as a rule, were the bright spots in each camp. They were kept as hospitals should be kept-clean and fresh, and method after method which made for cleanliness was readily adopted; they were, in fact, the show places of the camp.

It is no exaggeration to declare that the main advance in the Canadian Militia from Igo6 to the opening of the war was in the steadily increasing realization that where men are massed together their welfare and their effectiveness centre around the preservation of their health, and that sanitation is a matter that concerns all. And to the next Director-General fell the task of bringing about this realization and obtaining the co-operation of all the military authorities in the campaign of rational hygiene. For in '1906, when Colonel Pinault, the Deputy Minister of Militia, fell ill, the duties of his office were taken on by the D.G.M.S. in addition to his own; and upon the death of the Deputy Minister, Colonel Fiset was appointed to the vacant position, and Lieutenant-Colonel G. Carleton Jones*,

- Colonel (now Surgeon-General) Guy Carleton Jones, C.M.G., is a Nova Scotian, born in 1864 , the son of the late Hon. A. G. 


\section{RISE OF THE C.A.M.C.}

who had been Principal Medical Officer for the Maritime Provinces, was called from Halifax and made Director-General in his place.

The co-operation above noted was obtained in a somewhat paradoxical manner. On first consideration it might be thought that the direct method would be most effective-namely, to endow the medical officers with greater powers. But to do this would mean divided authority in the unit and in the command. As a matter of fact, in what may for comparison be termed the pre-sanitary days, the responsibility for sanitation was placed upon the M.O. without, however, affording him the means to carry out his recommendations. On further consideration this will be seen to have been a shelving of responsibility by the officer to whom the duties rightly belonged. Camp sanitation is a matter of discipline, the discipline of cleanliness, and all matters of discipline are, and ought to be, in the hands of the Commanding Officer. The Militia

Jones, well known as a Lieutenant-Governor of that Province, who for years had been a bitter political opponent of the late Sir Charles Tupper. Educated at Edinburgh and at a well-known Canadian school, the Galt Collegiate Institute, he obtained his medical training at King's College, London, and at Halifax. graduating M.R.C.S.Eng. in 1887 and M.D., C.M. Halifax Medical College, 1890. He entered the Volunteer Medical Service as Surgeon-Lieutenant to the ist Regiment, Canadian Artillery in 1896, and transferring to the Halifax Bearer Company in 1898, received his majority in 1899 . He served in South Africa as second in command of the roth Canadian Field Hospital 1900-2, receiving the Queen's Medal with two clasps; was appointed Lieutenant-Colonel P.A.M.C. in 1905; D.G.M.S. December, 1906, occupying this post until September, 1914, when he became A.D.M.S. First Canadian Contingent, a title altered to D.M.S. Canadian Expeditionary Force, December, 1914. In 1917 he was appointed Medical Inspector, Canadian Expeditionary Farce. He is now D.M.S. in charge of Hospitals in Canada. 


\section{WAR STORY OF THE C.A.M.C.}

Order issued in the spring of 1907 took the important step in advance of officially recognizing this. Henceforth the responsibility for sanitation was laid upon the O.C. If matters went wrong, upon him was to be placed the blame, and, as a result, he became bound to consult his M.O. and to follow his recommendations.

Colonel Jones's next move was to establish courses of lectures upon military medicine, and more particularly upon military sanitation, at each permanent station, to be given by the P.M.O. during the winter months to the permanent and active militia officers of the district. To these courses, and through the way in which they brought home to the medical officers the importance of hygiene, and to the working of the order just noted, must largely be ascribed the rapid improvement in the Service and its increasing influence. Plans were drawn up of the proposed sanitary lay-out of every unit with explanatory designs, and when, in the autumn of I907, the annual camp of the Nova Scotia district was opened, the Camp Commandant held a meeting of the commanding officers and regimental officers at Camp Headquarters, when a model installation of all the sanitary constructions required for a battalion had been prepared. These were carefully explained, and the plans and instruction given out, and within three days a sanitary encampment on the new model had been achieved, with ablution tables, shower baths and other sanitary needs, and the new constructions were not only working smoothly, but formed a subject of enthusiasm and pride to their builders. This difference in the health and comfort of the troops here and at Petewawa, the artillery 


\section{RISE OF THE C.A.M.C.}

camp held a few months earlier, was very noticeable. Indeed, Petewawa materially strengthened the hands of the Director-General, for through the milk supply a small epidemic of typhoid fever broke out in this camp, and while this was rapidly suppressed, the widespread publicity given to it afforded the militia authorities the opportunity to institute a general reform of the whole sanitary arrangements.

Roughly, the main maxim of camp sanitation is to provide a billet for every bullet of dirt, and dirt is matter in the wrong place : the right place must be provided for it. And this right place is not where it is hidden. To hide it away means that proper arrangements have not been made for its disposal. Thus, contrary to preconceived notions of propriety, constructions in a camp which are apt from carelessness to become dirty are now placed, not in a retired spot, but wherever they are likely to be most exposed, and where any possible defects or careless usage are brought into the limelight, and, for the credit of the camp, relentlessly repaired.

Colonel Jories had early recognized the advantage of affording a meeting ground for, and of bringing together, the medical officers of the permanent force and the militia. In his first year of office he utilized the occasion of the meeting of the Canadian Medical Association in Montreal to call a gathering of officers and to found an "Association of Medical Officers of the Militia." The meeting next year was held under similar surroundings. In I909 the association had proved its value, and was strong enough to hold a meeting of its own in February at Ottawa, with a good programme of papers and discussions. This annual meeting in 


\section{WAR STORY OF THE C.A.M.C.}

the winter became a regular event and did much to promote a good service spirit, to bring the officers from the different divisions to know one another and to kindle enthusiasm. Another step in the same direction was taken at London, Ontario, in I9II, where, in place of medical units attending the annual camps of their districts or divisions, there was held the first full Army Medical Corps Camp. Medical units from different districts were here brought together for sixteen days' training. Beginning with a scheme of attack and defence, which called into play purely the work of the regimental officer with a battalion, next schemes calling into play the work of the field ambulance with the brigade, and, finally, the divisional co-operation of field ambulance and casualty clearing unit were worked out, and an insight given into the functions and inter-relationships of the different branches of the service that no local annual camp with the infantry and other arms could have supplied.

And now was published the "Manual of Estab-" lishment and Equipment of the Army Medical Corps, Canada," for peace and for war. This, it may be emphasized, was the first official publication on behalf of any department of the Canadian Militia, in which the word "war" was used, or the state of being at war clearly faced. The corps camp at London served to test, and, where necessary, correct, every detail of the establishment and equipment as drawn up during the preceding months-the constitution of the different units, the stores necessary for each, the number of transport wagons essential for each unit, their packing, the contents of the Field panniers, the number and contents of 


\section{RISE OF THE C.A.M.C.}

the boxes of drugs and apparatus. All this was put to a practical test, with the result that when the war broke out there was no confusion, and, so far as regards medical stores and equipment proper, the medical units accompanying the First Contingent were ready to start.

Each year, prior to the war, the D.G.M.S. conducted a course at Ottawa, in which, winter after winter, the medical history of one or other great campaign was carefully studied, and laboratory training given in sanitation and bacteriology, this latter course being under the supervision of the D.D.G.M.S., Major Lorne Drum.* In short, so far as was possible with the framework of a regular army in place of a full regular army proper, the future administrative heads of such an army were given a thorough training; and they, in their turn, conducted courses of lectures and training during the winter months in their respective divisions, which all regimental medical officers were encouraged to attend. As a result, in I9r4, the D.G.A.M.S. could call to the Service, not an untrained herd of general practitioners, but a group of officers keenly interested in their work, familiar with the problems and difficulties of the Service, and, what is more, familiar with the forms and administrative procedure of the A.M.C. : men who fell rapidly into line.

The main weakness of any permanent Army Medical Service is that in the long years of peace

* Major (now Colonel) Lorne Drum, born at Quebec, 1871 ; graduated B.A. McGill, I892 ; M.D., C.M. 1898; Lieutenant Q.O.H. 1895 ; Second Lieutenant A.M.S. 1900 ; served in South Africa, 1902; Captain P.A.M.C. 1905; Major, 1906; Brevet Lieutenant-Colonel, December, 1914; temp. Colonel, August, 1917 ; D.D.M.S. 1915 ; A.D.M.S. Witley Camp, 1917 ; O.C. No. 3 Canadian General Hospital (McGill), 1918. 


\section{- WAR STORY OF THE C.A.M.C.}

the officer whose duty it is to undertake the medical supervision of a body of men in the prime of life obtains little opportunity for the performance of major surgical operations, little experience other than what may be termed minor medicine and surgery. The tendency is for the officer's professional capacity to become reduced in the same ratio as his administrative capacity becomes steadily raised. Now, admittedly, the ordinary medical man, working for and by himself, has not the stimulus to develop into a good administrator, and administrative ability is all-essential in dealing with large bodies of men. There is much to be said for the Canadian system, which provides a small nucleus of officers of the Permanent Army Medical Corps thoroughly trained in executive work, and a large body of medical officers conversant with the ordinary routine of Army Medical Service, who, at the same time, through their civil practice, have kept themselves thoroughly in touch with modern medicine and modern surgery.

In the seven years preceding the war other changes had taken place affecting the organization of the Canadian Militia in general. With the development of the North-West and growth of Alberta and Saskatchewan, it became necessary to modify the commands and districts, and with the medical organization of each the previous P.M.O.'s and S.M.O.'s were replaced by an Assistant Director (A.D.M.S.) in medical charge of each divisional area.*

* No. 1, London, Ontario; No. 2, Toronto; No. 3, Kingston, Ontario; No. 4, Montreal ; No. 5, Quebec; No. 6, Halifax; No. 10, Winnipeg; No. II, Victoria, British Columbia ; No. 13. Calgary, and (established in 1914) No. 14, Regina. 


\section{RISE OF THE C.A.M.C.}

One other and outstanding feature of the C.A.M.C. remains to be noted, namely, the relationship and status of the nursing service. As a young country developing an army with no old traditions to hamper it, the logical course could be taken, rather than that which can be excused only on historical grounds. The British Army Nursing Service, it will be recalled, began by Sidney Herbert calling in the services of Florence Nightingale to mitigate the terrible condition of affairs in the hospital at Scutari during the Crimean War. One has but to read Sidney Herbert's "Life" to realize that, great and admirable as was this devoted woman, she was the despair of the official, making it impossible to incorporate her and the organization she controlled as an integral part of the Medical Service. Thus, from the Crimea onwards, the Nursing Service in the British Army, and other armies which have copied it, has been an auxiliary rather than an integral branch. Nevertheless, the nursing sisters have for long been an absolutely essential section of the Army Medical personnel; their work is performed under the control and direction of the medical officers. There is not one adequate reason why, as a body, they should belong to a separate organization-or to one of several separate organizations.

Thus it was that in I906 the Minister deliberately created the Army Nursing Sisters as an integral portion of the Army Medical Service, under the command of a matron who, in her turn, is responsible to the D.G.M.S. Doing this, regulations were laid down as to the qualifications and course of training, and the fully qualified sister was given the relative rank of lieutenant. As distinguished from the 


\section{WAR STORY OF THE C.A.M.C.}

nursing sisters of all other armies in the field, the Canadian Nursing Sisters have thus military status; and are under direct military control. This explains their uniform and their "stars," which apparently have given offence to the illogical.

Now, although this is a delicate matter to place upon paper, yet, with reference to this grant of relative rank, it is essential to call attention to certain facts. While the best are peers of the best, and there are English, Scotch and Irish nursing sisters not one whit behind their Canadian sisters in any respect, socially, as a body, the nursing profession in Canada has, in the first place, a higher status than it possesses in the old country. It attracts, in general, the daughters of professional men, and those from comfortable households. In a family of daughters, for example, it is quite the custom in Canada for the elder girls, when they have been " out" for three or four seasons, to realize that they have had their opportunity, and rather than be in the way of their younger sisters, to elect to become nurses. It is a rule that Canadian Nursing Sisters have had, not a common, but a High School education, or what corresponds thereto. And as nurses their training has been very thorough, with fuller courses of lectures on the basal subjects than is usual in Great Britain. As a result, a remarkably large proportion of the matrons of the great hospitals in the United States are of Canadian birth and training. Add to this that the Canadian nurse embarked on her profession is paid on a scale which in Great Britain would be thought extravagant. But then she is thoroughly competent, and this high recompense is found eventually economical. But just as at Oxford and Cambridge we may 


\section{RISE OF THE C.A.M.C.}

encounter those who do not attain to the quality which we associate with graduates of the older universities, so, among the Canadian Nursing Sisters, an occasional individual may be open to criticism; yet certainly as a body, for capacity, alertness and bearing, the Canadian sisters deserve, and more than deserve, the rank which has been given to them. And in this war they have abundantly " made good."

It should be emphasized that this step was taken on military grounds, and by the Ministry and Militia Council, not as the result of any agitation by the nursing sisters themselves-in fact, some years before the suffragettes became militant. The experience of the Canadian Army Medical Service has abundantly justified the innovation and proved it to be right and wise.

The first Matron to be appointed was Miss G. Pope, R.R.C.,* who had been through the South African campaign as Matron. She was succeeded at the beginning of the war by Matron Macdonald, $\uparrow$ who, with the establishment of the Headquarters Staff in London, took charge there, under the D.M.S., of all matters connected with the nursing personnel.

- April Ist, 1908.

$\uparrow$ Matron-in-Chief Margaret Chisholm Macdonald, daughter of D. Macdonald, of Bailey Brook, Nova Scotia, graduated from the New York City Training School for Nurses in I895; served as N.S. in the Spanish-American War ; selected to accompany the Second Canadian Contingent to South Africa in 1899 served for eighteen months with Health Department of the Canal Zone, Isthmus of Panama; appointed N.S. in P.A.M.C. with rank of Lieutenant, November, 1906; Matron C.E.F. September, 1914 ; Matron-in-Chief, November, I914, R.R.C. 


\section{CHAPTER II}

THE ASSEMBLY AT VALCARTIER AND THE CROSSING

Ir was on Saturday, August Ist, I9I4, that Germany declared war on Russia ; on Sunday, the 2nd, that France entered into the war; on Tuesday, the 4 th, Great Britain.

On the 6th Canada took her first active step: By Order in Council His Royal Highness the Governor-General called out various corps upon active service; these including the Militia Council, the Permanent Staff at Militia Headquarters, Ottawa, and in the several divisional areas and districts all corps of the permanent force and various units in the different divisions. Among those called out were No. 7 and No. 9 Field Ambulances from Quebec and Charlottetown, Prince Edward Island, respectively.* Subsequent orders in these first few days called out No. I Clearing Hospital (Toronto) and No. I8 Field Ambulance (Vancouver). Rapidly Canada's part in the war became determined, and on August I7th was published the Mobilization Order, $\uparrow$ the first important instructions for general guidance, by which it was directed that there be mobilized for service overseas a Canadian Expeditionary Force, consisting of one

- This for temporary service at Quebec and Valcartier.

$\uparrow$ Militia Orders 372, 1914. 


\section{THE ASSEMBLY AT VALCARTIER}

complete division (less a brigade howitzer artillery), along with certain units, such as the Princess Patricia Canadian Light Infantry, in excess of divisional requirements, the force to be equipped in a manner similar to that of the British Regular Army, to be Imperial and have the status of British Regular troops. Already the Minister of Militia had selected the plain at Valcartier, near Quebec, as the assembly place, and the order laid down that the troops should concentrate there,* where final selection and acceptance for service would be determined and medical and veterinary equipment would be issued.

These were busy days for the Minister of Militia, and in nothing did his resourceful energy and initiative gain the whole-hearted admiration of the Dominion more than in the establishment of Valcartier Camp.

While fuller experience showed that it would have been less costly and more practical to have mobilized and selected the western troops at some central camp in the west, and Ontario troops at, say, Petewawa, and to have reserved Valcartier Camp for eastern troops only, $\uparrow$ it has, nevertheless, to be admitted that General Sir Sam Hughes's scheme appealed to the imagination. He came swiftly to the conclusion that an assembly camp was essential near to the port of embarkation, selected the ground at Valcartier, which was already under consideration for an artillery training ground; and realizing that this must be prepared

* The exception was made that the "Princess Pat's" should mobilize at Ottawa.

$\dagger$ This, as a matter of fact, was the plan adopted in connection with the assembly of subsequent contingents. 


\section{WAR STORY OF THE C.A.M.C.}

immediately, without waiting for formalities, votes, tenders, etc., with the approval of the Prime Minister he secured the ground, and placed its preparation as a camp for twenty thousand men in the hands of the engineers and of large contractors whose capacity for rapid and effective work was known to him, these and the local arrangements being under the supervision of Captain W. Price (now Sir William Price and Honorary LieutenantColonel), a leading citizen of and late Member of Parliament for Quebec, as his local representative. With Colonel Price were associated LieutenantColonel H. E. Burstall (now Major-General Sir H. E. Burstall, K.C.B.), Colonel W. McBain, and others.

It is a striking story this, of the conversion as though by magic of a countryside largely unreclaimed into a busy city ready to receive twentyfive thousand inhabitants. The situation was admirable-a gently sloping ground, in the main sandy, with an abundant supply of water from the Jacques Cartier river, which ran through it, and at a day's marching distance from the port. Farm buildings were razed, crops harvested. Hundreds of acres of second-growth timber were attacked by field companies from Toronto, McGill and Queen's Universities, and, as Captain Curry puts it, "A patch of land that one day was covered with cedars, would next day be bare of all but the stumps, the brushwood blazing merrily in huge fires. Next day the stumps would be gone, and by evening the area would be covered with tents."* Roads were made and bridges over the river; pavements built.

* "From the St. Lawrence to the Yser with the Ist Canadian Brigade," by F. C. Curry, late Captain and Eastern Ontario Regiment, 1916, page 32. 


\section{THE ASSEMBLY AT VALCARTIER}

Ditching machines, each accomplishing the work of fifty men, aided the speedy establishment of a drainage system, for which twenty-eight thousand drain-pipes were employed, and of a very complete camp water-supply. When Valcartier was taken over, Major H. M. Jacques, ${ }^{*}$ of the office of the D.G.M.S., after inspection, reported that there were only two wells in the camp area in which the water was possibly fit for drinking purposes, and that there was pollution of the Jacques Cartier river higher up, so that its water could be employed with safety only after chlorination. The establishment of a proper system was placed under the medical control of Major H. A. Chisholm; P.A.M.C., $\dagger$ as Sanitary Officer, until Dr. G. G. Nasmith, of the Ontario Provincial Board of Health, was by the Minister appointed head of a special department in the Army, the Hydrological Service, with the rank of Lieutenant-Colonel, and placed in charge of the watersupply under the A.D.M.S., at the camp. $\downarrow$ Pumps drew the water from the intake on Jacques Cartier river above the camp to tanks and a chlorinating plant, where the water underwent repeated daily

* Now Lieutenant-Colonel, D.S.O. and A.D.M.S. Military District No. 6 (Halifax, N.S.) ; Acting D.G.M.S. Ottawa, 1914 ; later D.A.D.M.S. and A.D.M.S. 2nd Division, C.E.F.

† Later Colonel D.A.D.M.S. Ist Division, A.D.M.S. 4th Division, and A.D.M.S. in charge of personnel in London. D.S.O.

† The wisdom of the choice was shown by Colonel Nasmith's subsequent career. Although not a medical graduate, and at most, therefore, attached to the C.A.M.C., Colonel Nasmith was virtually given the position of head of the Canadian (No. 5) Mobile Laboratory in France, and there showed himself so useful to the Imperial authorities as a consultant in applied sanitation, but more especially in connection with water supplies, that in 1916, after repeated mention in Dispatches, he was awarded the C.M.G. 


\section{WAR STORY OF THE C.A.M.C.}

tests. From here miles of pipes carried the water to every part of the camp, so that every company had its own ablution tables and shower baths, every cook-house its own water-supply; in the horse lines troughs were supplied which filled automatically. Incinerators were built for the destruction of refuse. It is doubtful whether any camp in the Empire planned and improved over years of experience and deliberation, possessed a better sanitary system than did this mushroom growth of a fortnight. In addition, three miles of siding were laid down in connection with the Canadian Northern Railway, which skirts the camp; electric light throughout the camp was supplied from Quebec. The engineers installed a field telegraph and telephone system, and there was constructed a unique rifle range, three and a half miles long-the longest, it may be remarked, in the world, with targets at which men could practise by the thousand.

Of necessity, it was a tented camp, but large hutment buildings were rapidly raised for Headquarters' offices, pay, and other purposes, and for stores-ordnance, army service, medical, etc.-and dry canteens (for alcohol was rigorously excluded from the camp and district). It is interesting to note that of these more permanent buildings the first to be erected was the pathological laboratory, which immediately busied itself over the watersupply. Soon a bank and a moving-picture theatre made their appearance, and with these the camp reached the level demanded by modern civilization.

The response to the call for men was such that by the middle of August the number necessary to form a division had been exceeded by four thousand.

On August I7th, the day of the publication of the 


\section{THE ASSEMBLY AT VALCARTIER}

mobilization order, troops were already beginning to pour in. On that day there arrived Io officers, 230 O.R., with 23 horses, of the 5th Field Ambulance from Montreal, followed rapidly between this and the 22nd by detachments from Nos. I, 2, 3, 4, 7, 8, 9 and Io Field Ambulances. On the 22nd there arrived 8 officers and 4I O.R. from No. 2 Clearing Hospital, Nova Scotia.* Day after day the sidings were filled with troop trains and freight cars. By the end of the month the camp was already over full.

At the beginning of September the total number of men under arms throughout Canada was 40,600; and after consultation with Colonel V. A. S. Williams, O.C. Valcartier, and his Staff, and the Os.C. of the various units, Colonel Sam Hughes approved of the reorganization of the camp and formation of a fourth brigade.

Besides the "Princess Pat's," the number of battalions outside the Ist Division had by now been swelled by the Royal Canadian Regiment (R.C.R.), two cavalry regiments, namely, the Strathcona Horse and the Royal Canadian Dragoons (R.C.D.), the Royal Canadian Horse Artillery (R.C.H.A.), and the 2nd Field Company Engineers. Early in September the War Office requested, in addition, the supply of Lines of Communication units, among which were included two General Hospitals, two Stationary Hospitals and a Casualty Clearing Station. And now the Dominion asked and received willing consent to furnish an additional ten thousand men, this number including the 4th Brigade and these additional units-a contingent

- Valcartier Camp Orders Nos. 64 and 175 of August 25th; 1914, and August 3oth, 1914. 


\section{WAR STORY OF THE C.A.M.C.}

of altogether $3 I, 200$ men with 7,500 horses, and the number still grew, until actually more than 32,000 men embarked in the Canadian Armada.

So large a camp of hastily organized units meant abundant work for the Medical Service. LieutenantColonel H. R. Duff,* A.D.M.S. of the 3 rd Division, was appointed A.D.M.S. of the camp. Unfortunately at an early stage he was thrown from his horse and severely injured, his place being taken on August 22nd by Lieutenant-Colonel J. W. Bridges, $\uparrow$ A.D.M.S. 4th Montreal Division. Gathered together rapidly and enthusiastically from all parts of the Dominion, all who offered themselves for service were given clearly to understand that the personnel of the contingent would be decided at Valcartier. Thus at Valcartier each man had to undergo a careful physical examination before being definitely enrolled, or, on the other hand, rejected. The labour of examining, passing upon and filling up the medical papers of more than thirty-two thousand candidates may be imagined. It required the work from morning until night of a staff of some thirty officers and a hundred clerical orderlies, $\ddagger$ the whole

* Lieutenant-Colonel Duff had been in South Africa, I8991901, and had the Queen's Medal with four clasps. On his recovery, he joined No. 5 General Hospital, and did excellent service at Cairo, as Head of the Medical Service of the hospital, until his death from pneumonia in 1916.

† Later O.C. No. 2 General Hospital, A.D.M.S. 3rd Division at the front, A.D.M.S. Bramshott and A.D.M.S. Shorncliffe Area.

‡ "Six clerks or legible penmen will be detailed from each Provisional Battalion to report to the A.D.M.S. each morning at 8 a.m. to aid in preparing Attestation Papers for recrniting and records of inoculation." - Camp Orders No. 186, August 31st, 1914 . 


\section{THE ASSEMBLY AT VALCARTIER}

under the direction of Lieutenant-Colonel A. T. Shillington.*

Further, all who had not already conformed to the regulations for the Expeditionary Force $r e$ vaccination against smallpox and inoculation against typhoid fever had to undergo the necessary treatment, and through the imperfection of many of the units this entailed an extraordinary amount of clerical work. There was no desire to submit those already inoculated to a second treatment; at the same time, it was essential for the safety of the force that none should go to the seat of war unprotected against what had been two of the greatest Army scourges. This work was under the control of Lieutenant-Colonel Hodgetts, $\uparrow$ assisted by a corps of ten officers and some twenty N.C.O.'s and men.

It is not a little interesting that the introduction of inoculation against typhoid fever as a (practically) $\ddagger$ compulsory measure was accepted without serious opposition. The practice was virtually unknown among the civil population of the Dominion. Nor had it before the war been introduced into the Militia. In the autumn of 1913

* Later O.C. No. 2 Canadian Stationary Hospital, A.D.M.S. in charge of personnel in London, and O.C. Kitchener Hospital, Brighton. Now retired.

† Lieutenant-Colonel Hodgetts had been Chief Sanitary Officer for the Province of Ontario, and later Medical Secretary of the Conservation Commission. Subsequently, upon the sudden death of Lieutenant-Colonel J. Burland, Major Hodgetts replaced him as Red Cross Commissioner in London, was promoted Colonel, and awarded the C.M.G. He resigned this position in 1918 .

$\ddagger$ The individual soldier was at liberty to refuge inoculation. but was advised that unless inoculated he would not accompany his battalion overseas. 


\section{WAR STORY OF THE C.A.M.C.}

the D.G.M.S., Colonel G. C. Jones, had been in England at the same time as the Minister of Militia, and had brought to the notice of Colonel Sam Hughes the valuable work accomplished by Sir William Leishman, R.A.M.C., in perfecting the technique of the procedure, and the striking results gained in the British Army. Sir Almroth Wright, when Professor of Pathology at Netley, had originally introduced anti-typhoid inoculation as a voluntary method during the Boer war. In that campaign the losses from typhoid (or enteric) fever were appalling - one out of every eight of the British soldiers in South Africa went down with the disease. With Colonel Sir William Leishman's improved method of preparing the vaccine, inoculation had become as widely prevalent in the Imperial Army as the curious distaste which exists in Great Britain for compulsory measures of any order would allow, and this with such good results that the more autocratic United States had no hesitation in making it compulsory for their Army and Navy. Within a year typhoid fever was to all intents and purposes banished from the American forces. The Minister of Militia applied, therefore, to the War Office to be granted temporarily the services of Sir William Leishman, with the result that this distinguished officer of the R.A.M.C. visited Canada in the early spring of I9I4, and, giving an admirable series of addresses at Ottawa, Montreal and Toronto, brought well before the Canadian medical and general public the advantages of the procedure. Thanks to this visit the country thus was well prepared to accept the innovation. We shall have later to demonstrate the remarkable results obtained.

As many of the troops arrived unprovided with 


\section{THE ASSEMBLY AT VALCARTIER}

regimental numbers, and were drafted from various regiments into units of the Expeditionary Force, the difficulty in tracing the papers and records of the individual seemed at times almost hopeless. But, over and above this, as drafts of various sizes came pouring in from all over the Dominion, each accompanied by its medical officer, the men had to be allocated to the battalion proper of the overseas contingent. It will be readily grasped that as each battalion is provided with one Regimental Medical Officer, where a battalion was made up from two or three militia regiments, this meant a considerable rearrangement of medical personnel. As many of these officers as could be spared were utilized for medical examination of the volunteers and for inoculation, but these were not adequate, and not a few of the medical officers of the First Contingent, including some of the most prominent, were members of units in Montreal and elsewhere who had not volunteered in the first place, but who had been summoned to Valcartier in order to aid in the medical examinations.

As a matter of fact, while by the mobilization order it was directed that medical units should mobilize at Valcartier and medical stores be issued there, this almost from the first was found impracticable. In the first place, as was foreseen, the Army Medical Service appealed to a very distinct and valuable element in the general population-to men who, while thoughtful, and, what is more, eminently patriotic, were not of the militant disposition, men who, in the absence of conscription and the long era of peace, had had no training as soldiers, to whom, before the full realization of what this war signified had been borne in upon us, the thought 


\section{WAR STORY OF THE C.A.M.C.}

of the active destruction of their fellow-men, even for the sake of a great cause, was distinctly repugnant. Such men are no cowards, as has been abundantly proved by their devoted and fearless work as stretcher-bearers at the front, than whom none are more exposed to bodily danger, and as a body they have suffered heavily. Cowards! Not merely have they suffered heavily, but there has been a higher percentage of casualties among the personnel of the C.A.M.C. at the Front than in the infantry, or, indeed, any other branch of the Canadian Expeditionary Force. Your ordinary soldier during an engagement, save when engaged upon an advance, has a certain degree of protection in the trenches. $\mathrm{He}$ is not expected to move from his place save during that advance. The call to the stretcher-bearer demands that he moves irrespective of protection; his duty is to bring in the wounded. And nobly have our bearers worked in the open, retrieving their wounded comrades of other branches. Many have seemed to bear charmed lives, working in full view of the enemy under machine-gun and rifle fire, shell and shrapnel, working without haste, intent upon their mission of salvage. Many-alas, too many !- have fallen. But in loyalty and patriotic spirit the men of the C.A.M.C. are not one whit behind their comrades in the fighting line. It is merely that to men of this order the saving of life appeals more than does the taking. And they applied in great numbers to join the C.A.M.C.: so much so that one regiment alone in the middle west (the 48 th Battalion) received no less than three hundred volunteers who, joining the C.A.M.C. in the first place, had to be transferred as being in excess of strength. And 


\section{THE ASSEMBLY AT VALCARTIER}

as the standards for eyesight, etc., are somewhat lower for the medical than for the militant branches of the Service, the country was saved the transport of a considerable body of men who might not have been found transferable at Valcartier.

And, in the second place, thanks to the organization before the war, the equipment and stores for the Field Ambulances had already been brought together to a very large extent in different Canadian centres, and the plan of local mobilization had already been worked out. It was, therefore, much more practical to mobilize a western medical unit at Winnipeg, an Ontario unit at Toronto, and $: 1$ eastern unit at Valcartier.

Thus it was that the Officers and personnel if No. I Field Ambulance were drawn from medical units in Eastern Canada-i.e., the Maritime Provinces, the Province of Quebec and Ontario up to and including Kingston, and came under the command of Lieutenant-Colonel A. E. Ross, ${ }^{*}$ the Senior Medical Officer in this area, who had been Mayor of Kingston and Member of the Ontario Parliament. Major R. P. Campbell and his unit (No. 5 Field Ambulance) were at first attached to this, but later he and many of the officers and personnel were transferred to No. I General Hospital. No. 2 Field Ambulance was drawn from Central Canada -i.e., from Ontario, with the exception of the Kingston and Ottawa districts, Lieutenant-Colonel D. W. McPherson, $\uparrow$ of Toronto, being placed in

- At Valcartier, President, Standing Medical Board. Now Brigadier-General, D.M.S. Canadian Section, G.H.Q., France.

$\uparrow$ Now Colonel and C.M.G. Officer in charge of the Ontario Military Hospital, Orpington. 


\section{WAR STORY OF THE C.A.M.C.}

command, while Lieutenant-Colonel W. L. Watt,* of Winnipeg, commanded No. 3 Field Ambulance, which was mobilized at Winnipeg with officers and personnel drawn from Western Canada. This arrived at Valcartier on September Ist as a complete unit with stores and equipment.

When the Lines of Communication units were authorized, those volunteering for service from the two clearing hospitals, No. I from Toronto, under the charge of Captain C. E. Cooper Cole, and No. 2 brought from Liverpool, Nova Scotia, under the charge of Major F. S. C. Ford, $\uparrow$ were largely amalgamated (on September 3rd, rgra), and sent to the front as No. I Canadian Casualty Clearing Station, under the command of Major Ford, Captain Cole being transferred to No. 2 General Hospital. The necessary general and stationary hospitals were formed de novo from men who had volunteered from the various medical units throughout Canada. No. I General Hospital had as its basis the volunteers, officers and men from No. 5 Field Ambulance, Montreal, brought to camp by Major R. P. Campbell, who was given temporary charge of the unit until Lieutenant-Colonel Murray MacLarent was appointed O.C. The majority of the officers and men of No. 2 General Hospital, drawn from this general list were from Toronto and other parts of Ontario.

* Now Colonel, C.M.G. O.C. Granville Canadian Special Hospital, Ramsgate, I9I 5 ; A.D.M.S. London Area, and O.C. Duchess of Connaught Canadian Red Cross Hospital at Taplow, 1917 ; A.D.M.S. Seaford, 1918.

† Now Colonel and C.M.G. A.D.M.S. Ist Division, until seriously wounded in June, 1917. At present Inspector of Military Hospitals, Maritime Provinces.

† Now Colonel, C.M.G. D.D.M.S. in London, 1916; O.C. Granville Canadian Special Hospital, 1918. 


\section{THE ASSEMBLY AT VALCARTIER}

At first, under the command of Lieutenant-Colonel Bridges, when this officer was appointed A.D.M.S. Valcartier, the command fell temporarily to Major R. L. Gardiner, of Ottawa, reverting to Colonel Bridges when the troops went overseas.* Similarly, as regards the stationary hospitals, the draft from No. 4 Field Ambulance from Montreal afforded a basis, with Major Hanford McKee $\dagger$ of that unit as O.C. No. 2 Stationary Hospital was brought together from the General List, and Major McKelvey Bellt was placed in temporary command, delivering up the position later to Lieutenant-Colonel Shillington.

There ensued, in fact, a period of rearrangement. Officers in the prime of youth belonging to the converted field ambulance units were transferred to their appropriate positions as Regimental Medical Officers: men of older standing who in their patriotism had accompanied the overseas drafts from their old regiments, found themselves removed to base hospitals units, where they would be of greater service. And when this had been accomplished, the modified units had to be trained, and as the particular aptitude of particular individualsor want of aptitude-revealed itself, a process of culling and frequent rearrangement was under-

* Many of these officers of the two General Hospitals were practitioners who had not originally volunteered, but who had been called to Valcartier to assist in the physical examination of the recruits.

$\dagger$ Now Colonel and C.M.G. O.C. Westcliffe Canadian Eye and Ear Hospital. Major McKee had been in charge of No. I Camp Hospital at Valcartier, and later of the Ambulance Train.

$\ddagger$ M.O. 5 th Dragoon Guards, Ottawa. Later A/D.D.G.M.S. Ottawa, and A.D.M.S. 6th District. Now on the Staff of the Canadian Invalid Soldiers' Commission. 


\section{WAR STORY OF THE C.A.M.C.}

taken, with the object of gaining the right man in the right place, and a maximum of efficiency.

In this way members of medical units from all parts of the Dominion found positions, whether as Regimental Medical Officers or as members of the staffs of field ambulances of hospitals. Of the two field ambulances first called up, No. 9, from Prince Edward's Island, in command of Major Yeo, opened up an improvised camp hospital at Valcartier for the treatment of local sick. These two units having been called up and not having volunteered, when the camp became organized, the hospital was taken over by No. 5 Field Ambulance from Montreal, and this unit was returned to its base. The other, No. 7 Field Ambulance from Quebec, under Major Percy Wright,* which had been doing duty at Lever's Camp, volunteered almost intact.

\section{The Crossing}

To convoy across an ocean in one body an army of thirty-three thousand men was an undertaking of a magnitude greater than had ever hitherto been attempted. In the Crimea Great Britain at no time had more than twenty-five thousand men; France had a larger number, but these arrived piecemeal over safe seas without a sign of the enemy. In South Africa, similarly, troops arrived in detail from Great Britain and India, Australasia and Canada. Napoleon made preparations to convoy I00,000 men across the twenty-five miles which separate France from England, but never convoyed

* Now Colonel. Later O.C. No. I Field Ambulance, D.A.D.M.S. and A.D.M.S. Ist Division. D.S.O. 


\section{THE ASSEMBLY AT VALCARTIER}

them; Trafalgar made him desist. The only comparable undertaking is the Spanish Armada three centuries and more ago, with 21,627 troops on board some 132 ships of a total of over 60,000 tons, for that period an adventure of even greater magnitude, but as disastrous as it was notable.*

The Canadian Armada, on the other hand, was both notable and favoured by fortune. But it was an adventure on a huge scale, requiring ample and most careful preparation. To requisition and employ for one purpose thirty-two great ocean liners was in itself an indication of the resources of the Empire : to shepherd them in perfect order and without a mishap across three thousand miles of ocean speaks volumes for both the navy which marshalled them and the mercantile marine in charge of the individual ships. Even if at this early period of the war the seas had been swept clear of German warships (which was not the case), there was always the sudden peril of the mine and the submarine. The collection of the liners in Canadian waters had to proceed cautiously; the rendezvous could not be divulged, nor again the date of sailing, while in addition the Admiralty had to make the convoying arrangements. The wonder is that in the time afforded the arrangements were so perfect. With no advertisement throughout Canada, day after day during the last week of September, troops marched from Valcartier to Quebec in the order of

* The convoy of the First Contingent from the United States did not, we believe, greatly exceed 20,000 men. We possess no figures for the convoys of 1918 , but some of them, utilizing the great commandeered German liners, filled to the brim with troops, will probably have exceeded in numbers the First Canadian Contingent. 


\section{WAR STORY OF THE C.A.M.C.}

their embarkation, they and their stores were expeditiously embarked, and liner after liner dropped quietly down the river to the place of rendezvous, until upon October 3 rd each vessel had been given its appointed place in Gaspé Basin, and thirty-one vessels in all were collected, with five accompanying war vessels.

This, however, is not a general history of the war ; these matters are but mentioned to indicate the profound impression made upon every medical unit that was privileged to be part of the great convoy. The many diaries that have come into my hands show that the two incidents which had the greatest appeal were the quiet assemblage of the liners in the beautiful Gaspe Basin, and the ordered departure from the bay.

The medical units accompanying the First Contingent were the following: No. I Canadian Field Ambulance, O.C. Lieutenant-Colonel A. E. Ross (of Kingston, Ontario); No. 2 Canadian Field Ambulance, O.C. Lieutenant-Colonel D. W. McPherson (of Toronto); No. 3 Canadian Field Ambulance, O.C. Lieutenant-Colonel W. L. Watt (of Winnipeg); No. I Canadian Casualty Clearing Station, O.C. Lieutenant-Colonel F. S. C. Ford (of New Germany, N.S.) ; No. I Canadian General Hospital, O.C. Lieutenant-Colonel Murray MacLaren (of St. John, N.B.) ; No. 2 Canadian General Hospital, O.C. Lieutenant-Colonel J. W. Bridges, P.A.M.C. ; No. I Canadian Stationary Hospital, O.C. Lieutenant-Colonel L. Drum, P.A.M.C. ; No. 2 Canadian Stationary Hospital, O.C. Lieutenant-Colonel A. T. Shillington (Ottawa).

Just as the D.G.A.M.S. in England, Sir Arthur Sloggett, found it essential to accompany the 


\section{THE ASSEMBLY AT VALCARTIER}

British forces overseas to Flanders, there to superintend an organization which had not been tested in any great war, so was it necessary for the D.G.M.S. Canadians to control the organization for which he had been so largely responsible, an organization which during the last seven years had been developed under his supervision. There was no other officer in the Service with the same intimate knowledge of the personnel of the various units and the capacity of individual officers; no one, again, so fully conversant with the medical staff at the War Office, and the methods of the Royal Army Medical Corps. It was far from being realized at this period what developments would take place, and that once overseas the expansion of the Service would be so great that a permanent Canadian Central Staff would inevitably have to be formed in England.

At Valcartier Colonel Jones, regarded as being in temporary medical charge of a division, reverted, when it was decided that he should accompany it overseas, to the status of A.D.M.S., with LieutenantColonel G. L. Foster,* late A.D.M.S. 2nd District (Toronto) as D.A.D.M.S. $\dagger$ Nevertheless, from the moment that Lines of Communication units were authorized, Colonel Jones had medical charge of more than a division, and the moment he reached England, dealing directly with the War Office, he had to assume the responsibilities of a Director of Medical Services. This was fully recognized by the authorities there, and, as a matter of fact, his

* Now Major-General and D.G.M.S., O.M.F.C., C.B., succeeding General G. C. Jones. At Valcartier Colonel Foster had been Chief Instructor, A.M.C. See also note, p. 115.

$\uparrow$ Militia Order (Canada), No. 463, October 14 th, 1914. 


\section{WAR STORY OF THE C.A.M.C}

promotion to Surgeon-General and appointment as D.M.S. was dated from September 2rst, I9I4. In the same order and from the same date LieutenantColonel G. L. Foster, P.A.M.C., was appointed A.D.M.S. Ist Canadian Contingent, and Major H. A. Chisholm D.A.D.M.S.*

In the absence of Colonel Carleton Jones, Major Jacques, of the P.A.M.C., was appointed Acting D.G.M.S. at Ottawa.

The passage was necessarily slow, the speed of the convoy as a whole being attuned to that of the weaker members, one or two of whom could with difficulty muster just under ten knots. To those accustomed to the Atlantic crossing the outstanding feature was the abundant exercise enforced-drills, games, marches and runs at stated periods. Thus, to quote the private War Diary of Captain P. G. Bell, $\nmid$ of the 3 rd Field Ambulance, which crossed on board the Tunisian :

" 28.9.I4. Have moved down to Rimouski by easy stages. ... Regular drills now at ro a.m. and 2 p.m. with physical exercises, marches and runs about the deck. We have established our tent division on board and taken over the ship's dispensary. Sick parade 9 a.m., lectures to the men daily on First Aid, etc. Food is very good on board.

"30.9.I4. Vaccination still in progress-did ninety-eight to-day myself. There are no 'con-

- Orders by Lieutenant-General E. A. Alderson, C.B., Commanding Ist Canadian Contingent, No. 1009, of January 24th, 1915.

$\uparrow$ Now Lieutenant-Colonel, D.S.O., four times mentioned in Dispatches; O.C. No. I2 Canadian Field Ambulance. 
scientious objectors.' . . . Inoculation for typhoid was voluntary, but nearly all not already inoculated accepted it, the insertion of some five hundred million little corpses into their bodies apparently not worrying them very much.

"I.ro.I4. Several of us are making a practice of taking a mile run every night at 6 p.m. (fourteen times round upper deck). We come down and tumble into a hot bath before dressing, which is all very nice, and is gradually, I think, getting us pretty fit. I am getting infinitely more exercise than I ever did on shipboard before. The men are marched and doubled about the deck for an hour daily, as well as having physical exercises."

But otherwise on the whole the seas were quiet, and the voyage was singularly uneventful. Land's End was sighted and passed during the forenoon of the I4th, and that afternoon the transports, all in battle grey, and now in a double line, ran in to Plymouth Harbour, rounding the point and past the Hoe with its memories of Francis Drake and that other Armada of centuries ago, and so they moved up the river to Devonport, and that same evening found all moored two by two to buoys at the Hamoaze, over against Devonport.

And here in the Hamoaze there was for many eager spirits a painful pause, for Plymouth, while welcoming the Canadians with the utmost cordiality, was unprepared for an invasion upon so large a scale. As a matter of fact, Southampton had been the original destination, but rumours of submarines lying in wait off that port caused a change at the last moment. The dockage space was small, and much naval work was in progress which was im- 


\section{WAR STORY OF THE C.A.M.C.}

perative, and could not be interfered with. Many days elapsed before the last transport came alongside and discharged its contents. It was, for example, five days before the Tunisian, with the 3rd Field Ambulance on board, landed its troops, and a week before the and Stationary Hospital found itself entraining at Plymouth for Lavington and Salisbury Plain. 


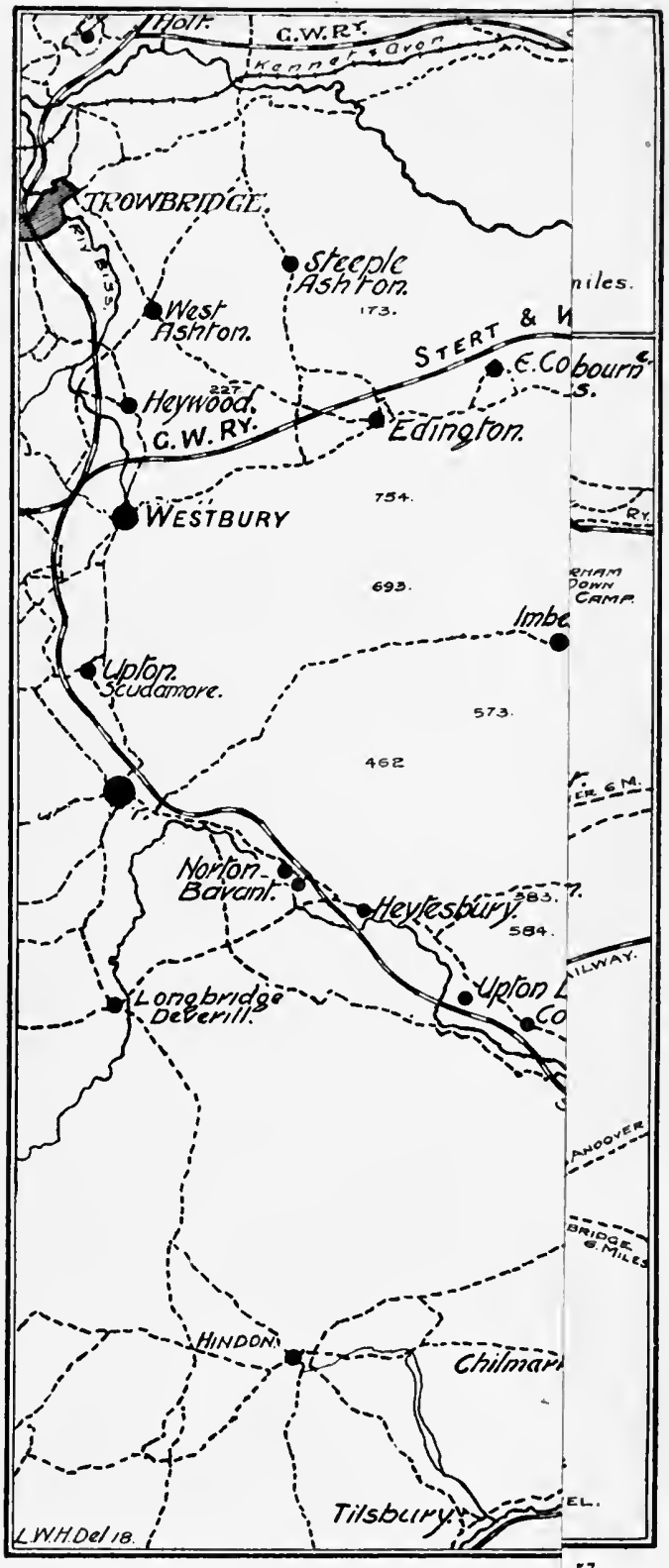




\section{CHAPTER III}

\section{SALISBURY PLAIN}

To those Canadians who have not been overseas, Salisbury Plain, as seen from the uplands, may best be likened to the rolling, grass-covered country stretching around Calgary, at the foot of the foothills proper, that is, when seen with the back turned to the Rockies-for here are no distant, snow-clad peaks, but in every direction is a wide horizon. Descend into the valleys and a very different impression is gained. Here nestle little, old-world English villages, with elm-shaded thatched cottages, and even thatched farmyard walls built of clunch -i.e., of chalk some four feet or so in thickness, with strengthening courses of brick; old Queen Anne and Georgian manor houses which, were they in the eastern states, we would call colonial; old gabled inns with swinging signboards and lowraftered rooms-villages which are mellowing into a gentle decay. For Wiltshire is an agricultural county that has not kept up with the march of the rest of the world, and its agricultural labourers have had the reputation of being more poorly paid than those in any part of Great Britain. All lads of spirit have migrated to the towns or across. the ocean, leaving behind the old and the very young, and those who find content in continuing 


\section{WAR STORY OF THE C.A.M.C.}

ways of life that satisfied their forefathers. But each cottage has its little well-cared-for garden, and somehow the villages give the impression of the simple life rather than of poverty, or, if of poverty, then of a poverty that respects and will not flaunt itself. The plain is curiously old world. Nowhere, save perhaps in Brittany, are to be found more abundant prehistoric remains-dolmens and cromlechs, long barrows and round barrows, camps, earthworks, dykes and roads, remains of neolithic man, of Druids, Romans and Saxons. Stonehenge is but one of many memorials of a distant past.

The plain covers a stretch of country some twenty-five miles from east to west, by fifteen miles from north to south. It is watered, and poorly watered at that, by five streams* which, distributed like the fingers of the outstretched hand, converge and join at or near Salisbury, which thus is the natural capital of the district, the centre to which all the main valleys trend.

The rolling downs, devoid of fields and fences, and the diminishing population, make this an ideal ground for camps and army manœuvres and exercises, and as such they have of late years been employed by the British Army. There is a pre-war cavalry school at Netheravon, and the least populated district to the north has been employed for artillery, with heavy gun and other ranges. It was in this area that the Canadians were camped.

Yet it has its disadvantages, as our Canadians were soon to experience. This undulating "down"

* As witness the many villages of Winterbourno-Winterbourne Stoke, Winterbourne Dauntsey, Winterbourne Earls and Winterbourne Gunner on the Bourno-all placed upon streams which run dry in summer. 


\section{SALISBURY PLAIN}

country is, geologically speaking, situated upon the chalk, a formation of which we have little or no knowledge in Canada. Perchance it was useful for us to become accustomed to it, since the formation extends over southern and eastern England, from Wiltshire on the west and Cambridgeshire to the north, across the Channel over northern France down to the Somme and the Champagne district. It makes for thin if not poor soil; the chalk is covered by a clayey compost from eight to eighteen inches in depth, with intermingled fragments of flint, and this pulverizes into abundant whitish dust in dry weather, and in wet. weather, since the water does not permeate the underlying chalk, it forms, when "puddled" by the feet of marching men, a most appalling quagmire-a mud through which one sinks it may be up to the knees, until brought to by the terra firma of the underlying chalk. That mud will remain a memory with the men of the First Contingent until their dying day-will, in fact, be the main memory of Salisbury Plain.

Most of the Canadians arrived at Lavington or Patney, or other stations on the outskirts of the Plain, in the early hours of the morning, and marched thence into camp through darkness. There at West Down North, in the reserved artillery area, medical units found the tents already pitched, put up by the British Army Service in expectation of their arrival. And now followed a winter of steady training-and yet more steady raining.

As for the training, the men were drilled, weather or no; were given route marches, even though the Canadian pattern army boot had not been built in anticipation of British rain and Wiltshire mud; they took part in concentration schemes, bivouacs 


\section{WAR STORY OF THE C.A.M.C.}

and manœuvres, now here, now there, over the plain. The Field Ambulance units went through the familiar routine in unfamiliar surroundings. There was not an officer of the three units who was not a trained member of the C.A.M.C., conversant with the field exercises of the annual camps. The same was true of most of the non-commissioned officers and of a large number of the rank and file. The personnel had been carefully selected. Now they found themselves, tent, bearer and transport sections, drilled and exercised and route-marched here and there over the Plain-marching to Salisbury with transport and equipment, the bearers acting as patients; or, again, they marched to Black Copse supposedly with the advanced guard, and the bearers were sent forward with their stretchers; an Advanced Dressing Station was opened up, and the tents pitched by the tent division as a Main Dressing Station further back; the cooks, too, being exercised, taking out the field kitchen and feeding the unit. In each camp to which they were attached they ran a Medical Detention Room in two or three hutments, for the treatment of mild and transient cases-cases under suspicion, or not deemed sufficiently serious to be sent to the main military hospital and struck off the strength.

The original arrangement with the Imperial authorities had been that the latter would care for cases of serious sickness and casualties occurring in the contingent, either in the Military Hospital at Tidworth, on the eastern border of the Plain, or in the General Infirmary at Salisbury to the south. This plan was defeated by the heavy influx of wounded from Flanders after the First Battle of 
Ypres. Like all the other large hospitals in the south of England, Salisbury Infirmary had little accommodation to spare. It was decided, therefore, to utilize one of the Canadian General Hospitals as a camp hospital, only the most serious cases being sent to Tidworth and Salisbury, infectious cases to the Salisbury Isolation Hospital, and mental cases to the district asylum. No. 2 General Hospital, which had been the first to arrive on the Plain, had opened a camp hospital in the tents provided immediately upon arrival at West Down North, utilizing equipment lent by the 3 rd Ficld Ambulance, their own stores being still at Plymouth. In the last week of October this was taken over by No. I and greatly enlarged.* In a week the marquees were full and more accommodation was needed. Next, owing to the wet and inclement weather, every endeavour was made by the camp authorities to get the patients under shelter. Several houses were secured along the valley of the Avon: Bulford Manor, a fine old seventeenth century mansion; three commodious cottages, just completed for the use of officers of the Bulford Camp, and Ablingdon House, the residence of General Vaughan, which was most generously placed at the

* The orders were that No. 2 General Hospital should run the Camp Hospital, but, receiving a " rush" order and working at night, the officer in charge of the hospital stores forwarded the equipment of No. I Hospital out of the warehouse instead of that of No. 2. This latter unit has vivid memories of being landed from the Franconia and rushed to a waiting train at the beginning of nightfall, dumped at one o'clock in the cold, foggy morning at the little country station of Lavington with only their private kits, and of the eight miles' march through the night to West Down North, guided by a policeman on a tricycle. They thought the Fates somewhat spiteful in these early days. 


\section{WAR STORY OF THE C.A.M.C.}

disposal of the Canadian authorities by that dis tinguished officer. Many Canadians have grateful recollections of the care and attention bestowed upon them by Mrs. Vaughan. Somewhat later Figheldean House was taken over for convalescent patients.

It was on November 6th that Bulford Manor became the Headquarters of No. I Canadian General Hospital. Here was accommodation for sixty cases, under Lieutenant-Colonel K. Cameron,* head of the Surgical Service, with two rooms admirably adapted for surgical operations and preparation for the same. The accommodation soon became taxed to the utmost; one of the cottages was used as a residence for the nursing sisters, the other two for medical patients under the charge of Lieutenant-Colonel F. G. Finley. $\dagger$ In one of them rooms were set aside for the laboratory. On the Bulford cricket ground adjoining tents were erected, their number being augmented from time to time.

With this rapid enlargement and increase in the scope of the camp hospital, the personnel of No. I General was reinforced by a few officers and almost all the N.C.O.'s and men of No. 2 General. A few officers, N.C.O.'s and men remained in charge of a small hospital at Lavington on the western border of the Plain, but the greater number of the officers of this unit proceeded to France, there to be distributed amongst the British hospitals until such time

* Now Colonel, C.M.G. Later O.C. No. 2 Canadian General Hospital ; A.D.M.S. Bramshott Camp. At present O.C. Military Hospital, St. Anne's, Quebec.

+ Now Colonel, C.B.; one of the two Canadian Medical Consultants in Great Britain, returning to Canada, October, 1918. 


\section{SALISBURY PLAIN}

as the unit as a whole should become established there.

With the appearance of sporadic cases of cerebrospinal fever one of the commodious cottages was taken over by No. I General as an isolation hospital, and, as the condition demanded every care, the laboratory was installed in the adjoining cottage, with Captain A. Rankin* and Captain A. W. M. Ellis $\dagger$ in charge, working in co-operation with Dr. Arkwright, of the Lister Institute. Next, early in December, Figheldean House was taken over as an auxiliary hospital. At Christmas the number of patients under treatment exceeded one thousand. But, in six weeks, what with the flooded condition of Bulford and the increase in the number of cases, the accommodation provided proved inadequate, and the main hospital was moved to the Cavalry School at Netheravon, leaving the venereal section at Bulford. By the beginning of February the hospital had charge of twelve hundred patients. Altogether while on Salisbury Plain No. x General Hospital received and treated 3,993 patients, of whom I,249 were venereal and 46 cerebro-spinal fever, with a death-roll of 69 , one-third of which was due to cerebro-spinal fever.t Seven deaths

- Captain (now Lieutenant-Colonel) Rankin, Professor of Pathology at the University of Alberta, had previously a wide experience in epidemiology as chief bacteriologist in Siam. Later attached Canadian Corps H.Q.R., and O.C. No. 7 Canadian Cavalry Field Ambulance. He is now O.C. Canadian Convalescent Hospital for Officers, Matlock Bath.

$\dagger$ Now Majo: O.C. No. 5 Mobile Laboratory in France.

¥ On May IIth, two days before leaving the Plain for France, No. I General Hospital paraded to place flowers upon the graves of the dead Canadian soldiers, who were buried-thirty-one at Bulford, ten in Netheravon churchyard and one in Durrington churchyard. Neat wooden crosses, painted white and inscribed 


\section{WAR STORY OF THE C.A.M.C.}

had been from a virulent form of broncho-pneumonia, of which there had been fifteen cases.

With the Canadian troops scattered across the Plain from Pond Farm and West Down North on the west to Tidworth in the east, and the hospital detachments and auxiliaries similarly scattered in different villages over an area some nine miles across, not only were the administrative difficulties very great, but the admission and evacuation of patients was a constant source of great trouble. The number of ambulances was restricted, and of the three at the disposal of the unit, owing to the wretched state of the roads brought about by the heavy motor-lorry traffic and the continued wet weather, it generally happened that two were under repair. But for the co-operation of the Divisional Ammunition Park at Netheravon, and the motor transport afforded by them, it would not have been possible to " carry on." Despite all these difficulties, the unit under Colonel MacLaren worked with a will and proved itself most effective.

As for the raining - there was a downpour so persistent that the oldest inhabitants remembered nothing to compare with it. The brooks overflowed and ran surly down the valley roads, expanding here and there into lakes; the tent floors were

with the name and battalion of each soldier, had been placed at the head of each grave, and a plan of the graves was sent to the Canadian Record Office in London. Nine days earlier a tablet to the memory of Captain Inglis, Chaplain to No. I General Hospital, erected by his brother officers of that unit, had been formally unveiled in the beautiful old parish church of Bulford. Captain Inglis, a fine example of an army chaplain, manly, open and devoted to the men under his care, had died of cerebro-spinal fever, contracted in the discharge of his duties while visiting the sick. 


\section{SALISBURY PLAIN}

morasses; it was impossible to keep dry. The rainfall for the month of December was the highest in fifty years, namely, 6.34 inches. The nearest approach was 6.25 inches in December, 1876 . Colonel Bridges informs me that out of seventy-five days, there were only five upon which it did not rain. If our officers found that rubber boots rising above the knees did not always protect them, the predicament of our nursing sisters passing over the quagmire from tent to tent, or from tents to quarters, was at times piteous. But the extraordinary part was that the troops appeared, despite the discomfort, to thrive upon it. The whole contingent, one would have thought, ought to have been down with rheumatic fever: but rheumatic fever was almost unknown. The open-air life, good food and abundant exercise kept the men in excellent health, until, after some six weeks, the discomfort of tent life and the increasing cold of winter induced the authorities to replace the tents by hutments, and then promptly influenza and throat troubles spread through the contingent. I cannot in this respect do better than quote from the report of a Regimental Medical Officer, Captain H. E. MacDermot,* M.O. Ist Reserve Ammunition Park :

"Our stay here lasted nearly six months, and in that time we lived under very varying conditions. But the most marked feature was the extremely heavy and persistent rain, which lasted from November to March with practically no intermission. The consequent discomfort was all that might be expected, especially during the first six weeks when we were housed in very poor tents. In November

- Now Major, No. 2 Canadian General Hospital. 


\section{WAR STORY OF THE C.A.M.C.}

our unit was moved into wooden huts and conditions were then a little better, but the encampment was still in process of building and so was very incomplete. ... The food was always good and plentiful, and canteens for extras were within reach. There were, however, very few, if any, means of recreation, and this aggravated the tendency to excess of one or other order. ... It is a little remarkable that under the conditions of wet and exposure there was no serious impairment of the health of the men. But I believe that the explanation of this lay partly in the exposure itself. It is noteworthy and beyond question the case that what illness there was increased at once and rapidly when the men moved into huts, with the attendant evils of accumulation of dust and insufficiency of fresh air. The huts, too, for a good portion of the time were overcrowded, and the comparative segregation of illness provided by the tents was largely lost by the crowding together in one hut of a number of men previously scattered through five or six tents.

"As might have been expected, the illnesses of the men were chiefly in connection with the respiratory system. A type of influenza developed, the worst feature being an extremely persistent and troublesome cough. There would be fairly high temperature, pains in the back and limbs and general malaise ; but this stage usually passed in three or four days, leaving the cough, which often lasted for weeks. . . .

"The one case of cerebro-spinal meningitis which occurred in the Park (it terminated fatally) developed in Tidworth Barracks a couple of months after we had moved there from the huts at Sling Plantation, where the epidemic of this disease amongst the 


\section{SALISBURY PLAIN}

surrounding battalions was at its worst. All precautions for isolation of the 'contacts' of this case were taken, and bacteriological examinations of their nasal passages were made. Three of the men so examined proved positive for the germ of the disease for a time, and were isolated and treated until their throat passages were found free from the germ.

"There were no cases of intestinal disease of any note. But in the latter end of January and the beginning of February there was a great number of cases of transient subacute enteritis. These occurred so frequently in a short space of time that I could only assume one common cause, such as faulty food or uncleanliness of cooking utensils. Close investigation, however, showed nothing of the sort. In every case the diarrhœa and colicky pains were checked quite easily by means of castor oil ; but at first the symptoms were always quite sudden and acute. One could not even say that the weather conditions at the time were any colder and damper than usual."

In view of the publicity already given to these subjects, it is necessary to note in fuller detail two matters connected with the health of the Canadian troops at Salisbury Plain-namely, the outbreak of cerebro-spinal fever and the venereal situation.

Cerebro-spinal fever (epidemic cerebro-spinal meningitis, or spotted fever) is a disease which, only recognized for the last hundred years or so, has been characterized by appearing in an epidemic form at irregular intervals. Years may elapse during which in any given city not a case is reported, and then the disease may carry off large numbers of 


\section{WAR STORY OF THE C.A.M.C.}

young children, together with occasional adults. This may continue for one, two or more years, generally dying down until again no more cases are reported, or a very occasional sporadic case. What is remarkable is that the disease has broken out among the soldiery in every modern war, as again that local epidemics have frequently been recorded in barracks in times of peace.

Now cerebro-spinal fever was reported from several parts of Canada in the autumn of I9I4; four cases occurred at Valcartier in September, and despite all care there in isolating those who had come into contact with the patients, three cases showed themselves on the convoy; two were soldiers, the other a ship steward's clerk. After arrival, seven cases were reported up to November 24th, scattered through the different battalions at Bustard Camp and West Down South, but there was no spread; on the contrary, for a period of three weeks, up to December I3th, not a single case was reported. Evidently the life in the open all day and in tents through the night arrested the disease. With the transfer to huts early in December it broke out again; there were fourteen cases in the second half of December, and ten of the fourteen were fatal. At this period every detail of happenings at Salisbury Plain was cabled to Canada, and when towards Christmas time reports of death from meningitis appeared in all Canadian journals day after day, the impression spread abroad that there was a grave epidemic; as a matter of fact, thanks to the precautions taken, the total number of cases in the thirty-three thousand men of the First Contingent from the time of its arrival to its departure from the Plain, did not exceed 


\section{SALISBURY PLAIN}

thirty-nine, though of these twenty-eight were fatal cases.*

With great willingness the Lister Institute placed one of its experts, Dr. Arkwright, at the disposal of the Canadian authorities. In the first week of January a laboratory fully equipped was established in a cottage at Bulford, and here a staff of well-trained Canadian Medical Officers assisted Dr. Arkwright in making a thorough bacteriological study of the cases-and, what is equally important, of the contacts. It has been proved that when the disease becomes epidemic, certain individuals, themselves showing no indication of the disease, may harbour the meningococcus (the causative agent) in their throats for a year and more, and may thus be the innocent instruments of conveyance of the disease to others, in whom the organisms no longer multiply passively on the moist surface of the throat and upper nasal passages, but gain admission to the tissues and body fluids, take an active growth and set up the disease. It is necessary, therefore, to detect these " carriers," for by isolating them as well as those succumbing to the disease, the spread can be arrested.

Now here are the interesting points about the Salisbury Plain cases. In barrack epidemics which have been studied in Germany, as many as ten carriers have been found among sixteen soldiers occupying the same room, and forty-two carriers among 485 men in the same battalion; indeed, it has not been uncommon to find from ten to thirteen

* Other sporadic cases occurred among the remaining Canadians and at the Training Depot after the Ist Division left, so that, from the weeks ending October 24th to May 1st, there was a total of fifty cases with thirty-six deaths. 


\section{WAR STORY OF THE C.A.M.C.}

per cent. of "carriers" among soldiers occupying the same room.*

The cases on the Plain, on the other hand, were widely scattered. Of the forty, ten are recorded as occurring at Sling Plantation, ten at Lark Hill, four at Bustard Camp, two at West Down North, five at West Down South, and others elsewhere. Eighteen different units contributed cases, the highest number contributed by any one unit being six in the I7th Battalion. In this battalion alone was there anything that could be said to approach a regimental epidemic; but even then these six cases all occurred during the second fortnight of December: there were no further cases; the resolute precautions taken stopped the spread. As a matter of fact, all the evidence at our disposal shows that we had not to deal with the usual room infection. Dr. Arkwright pointed out in his report to the D.M.S. that of 349 " contacts" examined (sisters who had nursed cases, men who had slept in huts along with a recent case of meningitis, etc.), 345 afforded. a negative result, and only four a positive ; that is to say, afforded growths of menin-

* In the Salisbury epidemic of 1915-i.e., among cases in the city of Salisbury and on the Plain (exclusive of the Canadian troops)-Lieutenant Johnston found :

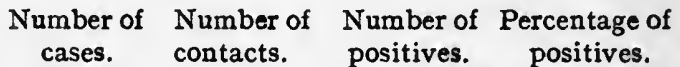

February .... 16

246

March...... I2

318

33

13.4

April...... 9

304

77

24.2

10.4

In married quarters (same room) of 43 contacts, 8 afforded positive results-i.e., 20.9 per cent. ; in hutments, 453 contacts gave 89 positives, or 19.6 per cent. Vide National Health Insurance "Report of Special Advisory Committee upon Cerebro-Spinal Fever," London, 1916, p. 37. 


\section{SALISBURY PLAIN}

gococci from their throats-a percentage of I.I2. Actually a higher percentage was obtained from the throats of non-contacts." "The low proportion of carriers detected at Bulford would suggest that the cases of meningitis did nct, as a rule, result from infection in the sleeping room, but from carriers with whom the case of meningitis came into contact elsewhere." At most, the transfer to huts with their poorer ventilation predisposed the men to infection. It is not improbable that the crowded canteens were implicated, and that the disease was conveyed through partially rinsed mugs and glasses. I am informed by Lieutenant-Colonel Armstrong, the Director of Canadian Dental Services, that at Witley Camp there has been a striking reduction in the number of cases of another infectious disorder known as Trench mouth (ulcerative stomatitis), since the order was put into force that in public drinkingplaces every glass or mug after use has its edge dipped momentarily into boiling water, and this in the presence of the customers. This order is enforced not only in canteens, but in the inns and bars of the neighbourhood, such drinking-places as have not installed the simple apparatus necessitated being placed out of bounds. Food utensils also are now well sterilized, and this, too, must exert a good effect.

What, for Canadian amour propre, is more irritating is that coincidently "spotted fever" was reported as breaking out in other parts of England. It was natural that the ordinary public should jump to the conclusion that the First Canadian

* Later figures confirmed these findings ; thus during January, out of $57 \mathrm{r}$ contacts and 662 non-contacts examined, the former afforded only 0.35 per cent. of carriers, the latter 4.8 per cent. 


\section{WAR STORY OF THE C.A.M.C.}

Contingent had introduced the disease, and was responsible; it is regrettable that the Special Advisory Committee by the unhappy wording of their report should without adducing adequate evidence, seem to support this suggestion.*

For what are the facts? Cerebro-spinal fever had been setting up minor epidemics for some years, more particularly in southern and south central England; in Ireland, at Belfast (1906-08) there had been a severe epidemic. In I9Io there was an outbreak in the Nottingham district; six out of eleven cases studied in the city and suburbs of Nottingham itself were shown to be " spotted

* " Report of the Special Advisory Committee upon Bacterio. logical Studies of Cerebro-Spinal Fever during the Epidemic of 1915," London, 1916, p. 50 :

"The reports from the Salisbury Plain area suggest, not, indeed, that the Canadians imported a new disease into this country, for we have always had it with us in a sporadic form, but that they did introduce a virulent strain of the meningococcus, and were in some degree responsible for its spread."

As a matter of fact, there is no evidence that the Canadians introduced a particular strain of meningococcus, or that the strains isolated from Canadian cases differed in any particular from the strains obtained from purely British cases; the strains were found to be identical in their properties. Nor was the mortality among those affected at Salisbury Plain greater than that in outbreaks in other parts of England, in which the Canadians were found innocent of responsibility. As to the degree of Canadian responsibility, this ought not to have been even hinted at in an official document unless it had been clearly determined and had been found to be serious. In the course of the very same paragraph quoted from, the Advisory Committee admits that Lieutenant Johnston, who studied the one particular area where it was most likely that the Canadians were implicated -namely, Salisbury and Salisbury Plain-reported that "the three first cases of the disease on the plain were in Canadians, in October and November, 1914; but that only in 18 per cent. of the other 65 cases could even probable association with Canadians be traced "-i.e., that the degree of responsibility of the Canadians was as 18 is to 82 ! 


\section{SALISBURY PLAIN}

fever " by the recognition of the organisms in the spinal fluid.*

And the disease was spreading, so that in September, I9I2, cerebro-spinal fever was at last added to the list of compulsorily notifiable diseases in every sanitary district of the British Isles, $\uparrow$ and from September Ist to the end of the year I04 cases were notified, in I9I3, 305, and in I9I4, 3I5.

Coming to I9I4, in the autumn cases were being reported as follows :t

\section{ENGLAND AND WALES}

Number of cases notified each week (not including patients from overseas) :

Cerebro-Spinal Fever

1914.

Weex ending Military. Civil.

September 26th ...... I

October 3 rd ......... 3

October roth........ $\quad 7$

October I 7 th......... 2

October 24th......... I 5

October 3 Ist ........ 2 2 6

November 7 th $\ldots \ldots \ldots$ I $\quad 2$

November I4th....... I 2

November 2 Ist ....... 3 I

November 28 th...... $3 \quad 5$

December 5 th ........ I -

December 12th ....... 3 I

December 19th ....... I3 9

December 26 th $\ldots \ldots \ldots$ I 13

* Report of the Medical Officer (Local Government Board), I911-1912, Appendix A., No. 4: Dr. Reece's Report, p. Io0.

$\dagger$ Report of the Local Government Board, 1914: Supplement containing the Report of the Medical Officer, p. xviii.

† Ibid., p. ix. 


\section{WAR STORY OF THE C.A.M.C}

There had thus been more than a dozen cases of cerebro-spinal fever reported in the month before the contingent set foot on British soil, or could possibly have communicated the disease; and the first case developing at Salisbury Plain (on October I8th) coincided in point of time with the first case notified among the Imperial troops. There is absolutely no evidence that the Canadian troops are responsible for the spread of the disease in the Eastern command and elsewhere in England. The fact is that when the disease is already present in a country and the weather is raw and damp, there is certain to be an outbreak among the troops unless those precautions be taken which the experience of the last four years has shown to be effective.

Regarding the venereal situation, old-established reticence makes it difficult to state in plain terms the exact state of the case, and that although the Times at last has cscaped from circumlocutions, and allows the term "syphilis" to appear upon its pages, and a Royal Commission upon Venereal Diseases and its conclusions have been extensively commented upon in the public Press and wherever thoughtful men and women are congregated.

The writer himself has for years taken the stand that the proper way to deal with this problem is by perfect openness.* But he appreciates the patriotic way in which many of the clergy and others who hold opinions diametrically opposed to his, have consented not to make this matter of the

- See his address- " Unto the Third and Fourth Generation -delivered at the Public Session of the Canadian Medical Association, at their Edmonton meeting (Lancet, London, November 2nd, 1912, and Montreal Medical Journal of tho same yearl. 


\section{SALISBURY PLAIN}

venereal problem in the Army a live issue during the course of the war. Were he in an official publication to give, he would not say his own views, but those of the heads of the medical corps and of the Service in general, or were he merely to give detailed statistics, and that without comment, he would by either act open the flood-gates of discussion and invite such criticism as for the good and efficient working of the Army is best delayed until the conclusion of hostilities. Later, this matter of the methods of control and suppression of venereal disease in Canada and among Canadians must be taken up by the Dominion, the military situation being but one part of the greater problem.

This much, however, may be said: from the Canadian corps in the field venereal disease has been almost eliminated. In the Army at large the incidence of the disease is much less than in any previous campaign, less even than in civil life.* Public opinion must be educated in future to deal with this subject, as it has been educated to accept vaccination against small-pox and inoculation against typhoid. By such means it is not too much to hope that the graver malady will disappear as effectually as these other two diseases.

With reference to the medical units other than the field ambulances and No. I General Hospital, and their activities during the period of training; to No. 2 Stationary Hospital was granted the dis-

* At the time of correcting this for the press (August, 19181 only 2 per cent. of the men being returned to Canada from the Discharge Depot at Buxton afford a positive Wassermann testi.e., show evidence of syphilitic infection, as compared with an average of from 8 to 12 per cent. found in the general hospital admissions in the large cities of England and her Dominions, and the United States. 
tinction of being the first of all Canadian units to place foot upon French soil. This unit, under Lieutenant-Colonel Shillington, after the inspection by Their Majesties the King and Queen two days previously, left the Plain on November 6th. IgI4. At Southampton the O.C. was detained by arrangements concerning the nursing sisters, and thus it devolved upon Major H. C. S. Elliot,* the second in command, to take the unit across the Channel to Havre. For a few days it was billeted at Boulogne. On November 27th it opened up the well-known Hôtel du Golf at Le Touquet, on the dunes near Paris Plage, as a hospital of three hundred bedsthe first of a series of Canadian base hospitals along the French coast between Boulogne and Dieppe.

No. I Stationary Hospital was detained in England, with the intention that it should open up as a base hospital in the immediate neighbourhood of London. For this purpose a new and admirably situated hospital, St. Vincent's Hospital, at Mount Vernon, Hampstead, was allotted to it by the Imperial authorities; the unit was transferred there and immediately set to work to transform this into a military hcspital. But, on further consideration, the authorities found that this would better subserve other purposes. $\uparrow$ And so, on

* Now Lieutenant-Colonel, O.C. No. is Canadian General Hospital.

$\dagger$ In the summer of 1915 it became the Hampstead Heart Hospital for the special study and treatment of "soldier's heart," with Sir Clifford Allbutt, Sir William Osler and Sir James Mackenzie as its consultants, and a staff of experts which included two Canadian officers specially attached, both of whom had already won their spurs in the study of heart disease-Major J. C. Meakins and Captain T. F. Cotton. 


\section{SALISBURY PLAIN}

February 2nd, I9I5, No. I Stationary Hospital followed No. 2, and was dispatched to Boulogne, where it opened up at Honeault Camp, Wimereux. Early in August, at the request of the War Office, Major Handford McKee took his unit to the island of Lemnos, off the mouth of the Dardanelles, there to participate in the Gallipoli campaign.

Of No. I and No. 2 General Hospitals the story has been given in the preceding pages.

No. I Casualty Clearing Station, after six weeks (f field training, was sent to Taplow, where Major Waldorf Astor had generously placed the closed tennis court in his beautiful grounds at Cliveden at the disposal of the Canadian authorities, to be used as a hospital under Canadian control. That hospital has grown greatly since those early days, so that the spacious wards in the tennis court form now but an inconsiderable portion of the great Duchess of Connaught's Canadian Red Cross Hospital, or, as it is now known officially, No. I5 Canadian General Hospital. But to Major (now Colonel) Ford and his staff belongs the credit of establishing those first wards. At the beginning of February, I9I5, a special staff was appointed under the late Lieutenant-Colonel Gorrell (of Ottawa), and in the first week in March, after some three weeks spent in a rest camp at Graville, No. I Canadian C.C.S. found itself taking possession of the old historical military prison, Fort Gassion, on the banks of the Lys, outside the fine old town of Aire, some seventeen miles behind the firing line, there to remain for many months.

It was in February that the main body of the First Contingent, now the Ist Canadian Division, was transferred to France. The "Princess Pats," 


\section{WAR STORY OF THE C.A.M.C.}

which were not divisional troops, had left the Plain early in December. His Majesty the King made a last inspection of the division on February 4 th, ${ }^{*}$ and the following day it marched off the Plain, and by the middle of the month the last transport reached St. Nazaire, leaving behind in England five unhappy battalions to form the base brigade of the division. These were moved later to Shorncliffe to form the Canadian Training Depot, the nucleus of the Canadian Training Division.

No. I General Hospital being responsible for its patients, could not leave with the division, but remained on the Plain. Figheldean House was closed in the middle of February. At the end of the same month the reinforcements from No. 2 General Hospital were returned to their unit at Lavington Manor. In the first week in March the evacuation of patients from Netheravon was completed. Only upon May $5^{\text {th }}$ was the evacuation for all patients from the unit accomplished, when the last batch of venereal patients in the tent hospital at Bulford was transferred to Shorncliffe, and on May I3th the unit entrained at Amesbury for France.

Shorncliffe now replaced the Plain as the reserve and training camp for Canadian troops, although, for valid reasons, the Director of Medical Services, along with the Pay and Record Departments, established their headquarters in London.

* At their first inspection on November 4th, 1914, Their Majesties had been accompanied by Lord Roberts and Lord Kitchener and the C.A.M.C. units had paraded as a body with a total parade state of 631 of all ranks, Lieutenant-Colonel Murray MacLaren in command. 


\section{CHAPTER IV}

\section{WITH THE B.E.F., FRANCE}

THIs is not the full and final history of the C.A.M.C., with all documents provided and every move of every unit carefully traced and recorded. Rather it is, to employ Lord Beaverbrook's phrase, a " contemporary history," the first object of which is to recall to those interested the good work accomplished by the Army Medical Service, before through the lapse of time their interest has been dulled. It is not the intention, therefore, to note every detail connected with each unit of the C.A.M.C. and its doings. I imagine that to most of us our past lives are not recalled as a steadily moving procession of events, but as a series of vignettes, those events standing out well and sharply which affected us most acutely, whereas the intermediate days and months have left upon us little or no impression. It will serve best in such a contemporary history to dwell upon the great moments of the war, and the participation in them of the Canadian Army Medical Service, taking care at the same time to do justice to those units which, not immediately involved in actual warfare, have done valuable work upon the Lines of Communication, at the "base" in France, Mudros and Salonika, in England and 


\section{WAR STORY OF THE C.A.M.C.}

in Canada. Doing this, more particularly the endeavour will be made to follow the progressive development of the various orders of units and their modification in response to the novel conditions which distinguish this from all previous wars.

This may safely be said, that Salisbury Plain, with all its training and hardships and inconveniences, had converted the Ist Canadian Division, under General Alderson, into well-seasoned soldiery. When, in February, 19I5, it reached Flanders, it was in so good a condition that rapidly it fell into place. Winter, it is true, accompanied it, with snow and sleet and slush; but this was as nothing. At last it was at the seat of war and part of the British forces under the supreme command of Sir John French.

Those forces held at that time a front of less than thirty miles, stretching from Ypres on the north to Givenchy. It was organized into two armies. Of these, the First, or Southern,* covering the ground from Nieppe, near Armentières, to Estaires and Givenchy, was under General Sir Douglas Haig; the northern, $\dagger$ from the Bailleul area to Ypres, was under General Sir H. Smith-Dorrien. The Canadian Division consisted of three brigades $\ddagger$

* Composed of the Ist, $4^{\text {th }}$ and Indian Army Corps.

t Composed of the and, 3rd and 5th British Army Corps.

¥ The Ist Canadian Brigade, under Lieutenant-Colonel Mercer (later Major-General), was formed of : ist Infantry Battalion (Western Ontario Regiment), and Infantry Battalion (Eastern Ontario), 3rd Infantry Battalion (Toronto Regiment) and 4 th Infantry Battalion (Central Ontario).

The and Brigade, under Lieutenant-Colonel A. H. Currie (now Lieutenant-General in command of the Canadian Army Corps, K.C.B. and K.C.M.G.), was formed of : 5 th Infantry Battalion 


\section{WITH THE B.E.F., FRANCE}

(to each of which was attached a Field Ambulance). Colonel G. L. Foster (now Major-General, D.G.M.S., O.M.F.C.) was in command of the Divisional Medical Corps as A.D.M.S.

It was at this point that the first grave administrative difficulty became obvious. There could be no question of running the medical, or any other section of the First Contingent as a body independent of the British authorities; the terms of Canada's offer to Britain precluded that. The Contingent was to be part and parcel of the British Regular troops and the British Army. But the personnel, and to no small extent the medical supplies, of the Canadian Division came from Canadian sources, and to this extent the A.D.M.S. remained dependent upon his Canadian superior, the D.M.S. With this, at the front he was under the D.D.M.S. of the corps to which the division was attached, and of which it formed a part; the Canadian Casualty Clearing Station was under the D.M.S. of the Army, and the Canadian Stationary and General Hospitals under the D.M.S. Lines of Communication, but more directly under the A.D.M.S. or S.M.O. of the district in which they

(Western Canada), 7th Infantry Battalion (rst British Columbia), 8th Infantry Battalion (Winnipeg, 9oth Rifles or "Little Black Devils ") and roth Infantry Battalion (Alberta).

The 3rd Brigade (Colonel, now Lieutenant-General, Sir R. E. W. Turner, V.C., K.C.B., K.C.M.G., D.S.O.) included the I $3^{\text {th }}$ (Royal Highlanders of Canada), 14th (Royal Scots of Montreal), I $5^{\text {th }}$ (48th Highlanders of Canada, from Toronto) and the 16th (Canadian Scottish).

The Artillery of the Division was under the command of Lieutenant-Colonel (now Major-General Sir) H. E. Burstall, K.C.B., and the Divisional Engineers under Lieutenant-Colonel (now Brigadier-General) C. J. Armstrong. 


\section{WAR STORY OF THE C.A.M.C.}

found themselves. For the D.M.S., Canadians, General Carleton Jones, to have become attached to the staff of Sir Arthur Sloggett, D.G.M.S. in France, would have placed him immediately in an anomalous position. By British Army procedure he would have had no right to enter the territories of other D.M.S.s; those officials had complete control over the units in their respective areas; nor could divided authority be countenanced, and yet it was essential that he should keep in close touch with each Canadian medical unit. The Imperial Army regulations, indeed, had never contemplated this state of affairs.

It was equally essential that he should keep in close touch with Canada, with the Reserve and Training Division in England, and with the D.G.A.M.S. in Great Britain, Sir Alfred Keogh, who was in control of medical arrangements there. To carry on in these circumstances needed an intimate knowledge of British Army procedure, an intimate personal acquaintance with the heads of the British Army Medical Service, and tact. And the D.M.S. possessed these attributes.

What has proved a "common sensible" compromise was rapidly reached, and the good spirit and friendliness of all parties concerned has caused it to work without serious friction. It was decided that the D.M.S. Canadians should have his headquarters in London, but that he should be at liberty to cross to the seat of war whenever necessary, under and with the authority of the D.G.M.S. overseas, to visit the Canadian Medical units in the various areas, and, conferring with the D.M.S.S of these areas, through them and through the D.G.M.S. (Sir Arthur Sloggett) to initiate such 


\section{WITH THE B.E.F., FRANCE}

changes in distribution of the units and personnel as should mutually be agreed upon.

After a short stay, mustering and training behind the lines, with the beginning of March, I9I5, the Canadians moved to the front west of Estaires, Sailly and Laventie, and south of Armentières, as part of the first British (Sir Douglas Haigs) Army. And here within a very few days it participated, although only as little more than an onlooker, with but an occasional casualty, in the Battle of Neuve Chapelle. The Canadian trenches, in fact, adjoined those of the British troops to the south concerned in the action of March Ioth. Had the day gone otherwise, our men would have been called upon to take part in the advance, and they were all prepared. But Neuve Chapelle taught us that it is not the first but the second and third lines of the enemy that count; that it is not sufficient for the artillery to prepare the way for entrance into the first line of trenches ; there must be fire of such intensity as to render at least the third line and its communications untenable. And in those days the British artillery and the amount of ammunition at its disposal were inadequate to accomplish this. But here, at a bound, the Canadians saw battle.

The only Canadian unit that actually participated in the Battle of Neuve Chapelle was the Ist Canadian Casualty Clearing Station. On March 8th, two days before the battle, LieutenantColonel W. D. Ford had brought his unit to Aire, some seven miles behind the front. Aire, on the winding Lys, is a delightful little old-world town, possessing one of the finest churches in French Flanders, with a tower curiously reminiscent of 


\section{WAR STORY OF THE C.A.M.C.}

English early Perpendicular architecture.* The town walls, with their bastions and three gates, were razed as late as 1893 .

Like the whole of this countryside, Aire has seen much war. $\dagger$ It was besieged and taken by Philip IV. of Spain in I64I, and certain stately old houses in the town, with their richly decorated fronts, still bear witness to the years of Spanish occupation. Philip it was who built Fort St. Francis, now known as Fort Gassion, $\ddagger$ a quarter of a mile outside the St. Venant Gate, and built it in orthodox seventeenth century fashion, octagonal, with large bastions and a surrounding moat and drawbridge with strong gate and gate-house. Recaptured by the French in 1676 , the fort, nevertheless, in its day, with its twenty-five guns and outworks, was a formidable protection to the town and obstacle to the enemy, as Marlborough found to his cost in the campaign of I7ro. With the able defence of de Guebriant and Fort St. Francis, and the marshes and inundations, the town only capitulated in

* The Perpendicular style is claimed to be characteristically English. It is true that the English still held a considerable part of France at the end of the fourteenth century, when this style developed; but Perpendicular influence is, if I remember aright, little noticeable in the area of English occupation-at Bordeaux, for example, and in Anjou; while here in Flanders, which is outside that area, the towers of St. Bertin at St. Omer, and of St. Pierre at Aire, in their proportions and buttresses might be those of some rich English collegiate church dating from 1400 or thereabouts, and passing a little further south, the panelling of the outer walls of the transepts of the noble mother church of St. Wulfran at Abbeville is pure Perpendicular.

† I am indebted to Colonel Ford for many of the historical data regarding Aire and Fort Gassion.

$\ddagger$ Since the Revolution and in memory of Major Gassion, who put up a brave defence of Aire in $164 \mathrm{I}$. 


\section{WITH THE B.E.F., FRANCE}

November, after a ten-weeks' siege, ${ }^{*}$ too late in the season for its capture to be of service, and at too great a cost ; for the Flanders rain and dysentery caused the loss of many hundreds of the English troops. Those were the days when opposing armies retired to winter quarters.

To-day moat and bastions have followed the fortifications of Aire and are no more; but the thick encircling walls of the fort remain, and the bridge and old-world gateway and gate-houses with the barrack-like buildings within. For years it had been used as a military prison, and here rumour has it Captain Dreyfus was confined for long months.

It was to Fort Gassion that the Ist Casualty Clearing Station was detailed on the Saturday. They found a motor ambulance convoy and a motor transport unit still in occupation. These were given no time to put matters in order, but received orders to leave forthwith. The old prison was, in fact, in a filthy condition, and as warning had been given to prepare for the forthcoming engagement, there ensued a period of feverish activity. The Army Service Corps came to their aid ; equipment was unpacked; the bigger rooms cleaned to act as wards ; and, losing not a minute, on Monday, March roth, the day the battle opened, the unit began admitting patients. That first day they had 50 patients, on Tuesday $15^{\circ}$, and on Wednesday $35^{\circ}$, the great majority of these being stretcher cases. And their work was urgent and necessary. In the spring of I9I5 the First Army possessed altogether six casualty clearing stations; to-day it has

* It is not a little interesting that Sir Douglas Haig, as head of the First Army, occupied the same headquarters that bad been Marlborougin's at the siege of Aire. 


\section{WAR STORY OF THE C.A.M.C.}

sixteen. At the time of the battle there were only two of these nearer to the front-at Merville. The prompt readiness and capacity of the unit received the special commendation of Surgeon-General W. G. Macpherson, D.M.S. First Army, and led in June to the award of the C.M.G. to Lieutenant-Colonel Ford.

The stay of the Canadian First Division with the First Army was of brief duration. Arrangements had been made with the French to extend the British line a few miles to the north, and the Canadians were selected to take over from the Irth French Division-the "Division de Fer"-the trenches protecting the northern sector of the Ypres salient. And so it was that on April $7^{\text {th }}$ the Ist Canadian Division was transferred to the Second Army under Sir H. Smith-Dorrien, marching out of the Estaires region northwards, Colonel Foster, A.D.M.S., moving his quarters from Estaires to Oxelaere. Ten days later the and and 3rd Brigades took over from the French the line north-east of Ypres, the Ist remaining in reserve.

"The French Medical Officers whom we relieved were very courteous, and explained to us how they had carried on while they had been stationed there during the winter months. They explained that each French regiment of three battalions had three M.O.'s and three assistants (who were usually students), and they worked together. The senior officer in this was a major, and was in charge of the medical work for the regiment. This system seems to work out very well and is more congenial for the M.O.'s. . . . The trenches were in very bad shape, and working parties, under guidance of the engineers, were working each night strengthening the parapets, building traverses, deepening the trenches, erecting 


\section{WITH THE B.E.F., FRANCE}

parados and putting out wire entanglements. There were many bodies buried at the bottom of the trenches, so the work was frequently very unpleasant and required a good deal of chloride of lime to keep down the smell of decay. This work, although not completed when the attack was launched, helped very greatly in resisting the assaults of the enemy."

In order to understand the happenings of the following days from a medical point of view, let us at this point describe the disposition of the medical units, so that the organization for the rapid disposal of the wounded as carried out in the British forces at this period may be clearly grasped.

The Regimental Medical Officer accompanies his men into the trenches, and, as against an attack upon those trenches, his duty is to select behind the line some spot well protected from shell fire, and as far as possible equi-distant from each of the companies at the front, there to establish his Regimental Aid Post (R.A.P.). For prompt evacuation of the wounded this should not be too far back. The approaches to it, also, should be screened from shell fire and snipers. He is provided with sixteen well-trained stretcher-bearers whose duty, as their name implies, is to convey the wounded back to the R.A.P. As a matter of fact, and as was discovered at Ypres, they are of greater service remaining in the trenches and affording first aid to the wounded, and as a body they develop into

* From notes afforded by Captain (now Lt.-Col.) G. S. Mothersill, M.O. of the 8th Canadian Battalion, who, after being seriously wounded on April 24th, eventually returned to his own battalion, now A.I.D. Canadian Corps. He was mentioned in Dispatches June 4th, 1917, and has been awarded the D.S.O. 


\section{WAR STORY OF THE C.A.M.C.}

extraordinarily capable and expert dressers. In consequence, it is becoming more and more the habit during any heavy action to retain these men for the more urgent work of dressing the wounded, and to employ other men detailed from the platoons to act as stretcher-bearers. If the R.A.P. is unduly distant from the front line, the return of the wounded is delayed by the length of the carry. The R.A.P. is, in short, the regimental collecting post to which all wounded, whether walking or stretcher cases, make their way. During an action the duty of the Regimental M.O. is not to be in the trenches, but at the R.A.P. There, with his N.C.O. and one or two orderlies, he attends to the wounded as they walk in or are brought back by the stretcher-bearers, and sees that each is given a tag, attached to a button of his tunic, giving his name, number, nature of wound, etc., prior to departure as a walking case, or removal by the bearers of the Field Ambulance.

I. In an action the first object is to remove out of the fire zone all who are no longer of service, and this as rapidly as possible. Thus the R.A.P. is not a surgery: it is at most a casualty ward. First-aid dressings are given, wounds are bandaged temporarily; splints, when urgently needed, are provided for fractured limbs; bleeding is arrested; morphia injected where injuries are painful, or strychnine where there is collapse.

2. From the R.A.P. those of the wounded who can walk make their way on foot to the Advanced Dressing Station (A.D.S.) of a Field Ambulance, which is situated within the fire zone at some roadside point up to which, if not always during the day-time, certainly at night the ambulances (usually horse ambulances) can be brought. The 


\section{WITH THE B.E.F., FRANCE}

more seriously wounded are removed on stretchers from the R.A.P. to the A.D.S. by men of the bearer section of a Field Ambulance. In the course of a heavy action this duty also can only be undertaken in the dark.

3. The next stage of the journey towards the base is, in general, performed in motor ambulances.* The greater number of cases are conveyed to the Main Dressing Station (M.D.S.) of a Field Ambulance. Here they undergo classification. The gravest cases are operated on immediately, and are kept at the M.D.S. until they are fit to be transferred to the Casualty Clearing Station. Mild cases also are given rest and treatment for a few days, until fit to return to duty, or if there be a rest camp in the neighbourhood, they may be sent there to recuperate. Every man saved from proceeding further to the base means a saving of many days' loss to his company. Other cases are sent to railhead with instructions, some for treatment at the Casualty Clearing Station, others for transfer to one or other special hospital (infectious

* It leserves note that even in the spring of I9I 5 the Motor Ambulance Service had not been conpletely established. For motives of economy, when the war broke out, the R.A.M.C. was still unprovided with motor transport, although this had been asked for. In the retreat from Mons the horse ambulances showed themselves to be painfully defective and inadequate for the heavy work they were called upon to perform. In April, 19I5, each Canadian Ambulance unit was provided with three motor ambulances, and these proved themselves to be of inestimable service. They were, however, needed for work between the A.D.S. and, where possible, Regimental Aid Posts, and the M.D.S. For this reason it was that the motor ambulance convoy was at this period in the process of development, this having to undertake the duty of convoying patients back from the M.D.S.'s to the Casualty Clearing Stations at railhead. 


\section{WAR STORY OF THE C.A.M.C.}

cases, eye cases, graver dental cases, etc.). The majority of those admitted leave the M.D.S. within twelve hours, the object being to evacuate as rapidly as possible.

4. In the early part of the war Red Cross ambulances, army transport, motors and motor-omnibuses, as they could be obtained, were employed for the conveyance of patients from the Field Ambulances to the Casualty Clearing Station.' These developed into a well-organized and most efficient motor transport corps, under the Army Service Corps.

5. The Casualty Clearing Hospital or Station is the next relay point. This is always situated in the vicinity of railhead, and, as its name implies, is the great forward clearing depot. Its first function is to accommodate the wounded for a few hours until, after their wounds have been cared for and suitably dressed, they can be placed in an ambulance train and sent to the base. But it is well behind the firing line, only within range, that is, of long distance guns, "Jack Johnsons" and the like. Cases needing both urgent treatment and rest in bed for several days following the operation can be treated here with safety. Thus, gradually this has developed into what may be termed an advanced surgical hospital and operating centre; wounds such that the only chance of saving the patient depends upon early treatment, wounds that would become so gravely infected by the time they reached the base as to be hopeless-wounds, for example, of the brain, chest and abdomenall these, to an increased extent, are dealt with at the C.C.S., and thus it happens that the personnel has been altered. Some of the most brilliant and experienced surgeons have been placed upon the 


\section{WITH THE B.E.F., FRANCE}

staffs of these units, and some of the most brilliant surgical triumphs of the war have here been achieved. Where, as at Bailleul, a good modern institution can be taken over for the purpose, this is utilized for the C.C.S. ; where, as at Remy Siding, near Poperinghe, this is wanting, there hutments are employed. Let me add that nowadays the latter are in more common use, since the principle has been evolved of arranging the C.C.S.'s in couples, so that they can receive patients on alternative days, the staff of the one hospital working at full pressure on its receiving day, operating and dressing the patients, and having a day of comparative rest, at most discharging patients into the ambulance trains and preparing for another succession of ambulance convoys, while the staff of the other hospital is working to its limit. In the early days of the war the C.C.S. had no beds proper, only stretchers raised on trestles off the floor, and hospital orderlies; to-day, when settled for long months in an appropriate building, it possesses cheerful and wellequipped wards for the more serious operation cases. To get into the front area as a C.C.S. Sister is the highest ambition of our Canadian nurses.

6. The ambulance trains have been so often described and pictured that there is little need to do more than mention them with their staff of medical officers, nurses and orderlies, their emergency operation-room and dispensary, their kitchen, dining-rooms for sitting-up cases and for the staff, and berths and other accommodation for the same. It must be kept in mind that in war the first thought has to be for the fighting force and the front line; for the good of the cause they are of first and immediate importance: those who have 


\section{WAR STORY OF THE C.A.M.C.}

fallen out of the ranks and become useless as combatants are a secondary consideration; they have to give way to the needs of the active soldiers. Thus in a country in which the lines of rails are mainly single, the long procession of trains bringing up men, guns, ammunition and other provisions to the front may gravely delay the return of the ambulance trains to the base. Wherever it is possible, traffic is so arranged that incoming trains proceed along one line, outgoing along another; but the ambulance train has to be prepared for all emergencies. It is to-day a marvel of comfort and efficiency.

7. Arrived at what often and incorrectly is termed the base-namely, the French sea-coastthe ambulance train is met by a line of motor ambulances. The number of stretcher cases has been telegraphed on in advance, and all is ready for transferring the patients, both lying-down and sitting, to one or other hospital. Each hospital in the area reports to the A.D.M.S. twice or more daily the exact number of beds that it has vacant, and no excess over that number of new cases is forwarded to it. There is no driving round from hospital to hospital seeking admittance ; everything is arranged with precision.

8. To-day the only distinction between a General and a Stationary "base" Hospital is that the former began by being double the size of the other, with double the number of beds and roughly double the personnel. School buildings, hotels and other institutions may well be utilized for a hospital of from three hundred to six hundred beds, and to such a stationary hospital unit was appointed To accommodate $I, 040$ patients, it was rare to find 


\section{WITH THE B.E.F., FRANCE}

any building large enough; your general hospital, therefore, was at first usually tented, the marquees giving place later and more and more to hutments. The original distinction between the General and the Stationary Hospital was that the former might be anywhere, the latter at some fixed point on the Lines of Communication, where it remained stationary ; whereas the General Hospital was prepared to move according to the needs of the Service. Originally, in South Africa, for example, the Stationary Hospital was situated in some small town well back along the lengthy Lines of Communication. Nowadays both General and Stationary Hospitals are alike situated on the French sea-coast, and they are alike in function, save that the larger body, with its specialists and its well-appointed pathological and X-ray departments, is apt to receive the greater number proportionately of the more serious cases. The mobility which, it is seen, originally characterized the General Hospital has become a function of a third type of unit not developed during the Boer War-namely, the Casualty Clearing Station at railhead, which is moved as the troops advance.

It is difficult for the civilian who has not been overseas to realize the size and extent of these base hospitals.* The smaller unit, the Stationary Hospital, accommodates more patients than any hospital in Canada, with the possible exception of the great new General Hospital in Toronto, more than the imposing Royal Victoria Hospital at Montreal, or the Winnipeg General. A General

- This is a civilian expression: there is no such term as Base Hospital overseas in military nomenclature : all hospitals, indeed, overseas are "Lines of Communication units." 


\section{WAR STORY OF THE C.A.M.C.}

Hospital overseas, with its personnel, orderlies, nursing sisters and officers, reaching into the hundreds, and its patients into the thousands, is a little town in itself. No. 3 Canadian General Hospital has to-day accommodation for well over two thousand patients! And when it is remembered that these are all in tents or huts of a single floor, that operation and other special departments, kitchens, stores, officers and nurses' quarters, mess-rooms for each branch of the personnel, admission tent or hall, patients' dining-room, recreation hut and administrative hutment, have all to be provided, some idea may be gathered as to the extent of such a hospital, and of the high quality of the organization demanded if all is to run smoothly and well, for the greatest benefit of the sick or wounded soldier.

9. But even with all this complete preparation and excellent accommodation, this is by no means the eventual place of treatment and recovery for the soldier patient, or, at least, for the majority. The Army maxim is " keep moving casualties backwards," and the endeavour is made to evacuate these hospitals rapidly. Mild and minor cases likely to recover and be fit for duty may be kept longer; some who have been operated upon must needs be retained until they gather strength and healing of their wounds; but the attempt is made to evacuate as many patients as possible within three days to "Blighty," in order that should a great push be made with many casualties there will be plenty of beds and to spare. Thus, usually every two or three days, the hospital is called upon to provide a batch of patients to be dispatched by next day's boat to England. It is, in truth, the 


\section{WTTH THE B.E.F., FRANCE}

rear Casualty Clearing Station. From a medica point of view, this is distressful ; the surgeon does not see the result of his handiwork; herein lies the great difference between civil and war-time military practice ; from an administrative point of view this is the only possible method.

ro. The hospital ships again are admirably organized. They have been provided with lifts, so that stretcher cases may be conveyed from the main to one of the lower decks. Men are classified into walking, sitting and cot cases, and the cots are swung so that the motion of the boat has a minimal effect. Each patient before leaving hospital has been tagged, so that on arrival on board there is no inquiry and delay, but immediately he is directed to his proper section. Each boat has its medical personnel and nursing sisters. The voyage thus is made with all care for the patient, even including attendant destroyers and dirigible balloon. Whether at the hospital or during the voyage, according to the nature of the case, arrangements are made to classify and tag the men, whether according to the nature of their condition (there being certain special British hospitals for special orders of cases) or the district to which they belong, or to which they desire to be sent; so that again on landing there is no disorder.

II. Under shelter, within a few yards of the hospital ship as she is brought to the moorings, is an ambulance train. A plentiful stream of bearers carry the stretcher patients down the gangway. The more serious cases are given first attention; after them follow the sitting and walking cases. Ambulance train after train, each bound for a particular district, is filled up and leaves quietly and 


\section{WAR STORY OF THE C.A.M.C.}

expeditiously. In a few minutes all the sick and wounded are speeding to different parts of Great Britain.

The medical officer in charge of a train has been afforded by the A.D.M.S. of a particular area information as to the number of beds vacant at each important town or distributing centre in his area. When thus the area is reached, ten patients are discharged here, fifty there, twenty-five at another place. Motor ambulances are waiting for them, and they are rushed off to hospital to find themselves admitted, given the luxury of a hot bath, a comfortable suit of pyjamas and at rest between the sheets-all, it seems, within a few minutes after leaving the train.

I2. And here they remain, it may be only a few days, it may be many weeks, until they can be classified as convalescent, when, if they are Canadian soldiers, they are transferred to a Canadian convalescent hospital. Whatever the nature of the ailment, and wherever they may have passed their period of active treatment, whether in some special hospital, or one of the great Canadian General Hospitals, such as Taplow or Orpington, or in an Imperial Hospital, be it in the north of Scotland or Ireland, all Canadian soldiers for convalescence are collected from the outer world into a convalescent hospital manned by the C.A.M.C. and under Canadian control. Here, from the beginning, they are subjected to a graduated and regular course of physical drill under qualified instructors, until the time comes for them to face full training with their reserve battalion, and return to active military life. 


\section{CHAPTER V}

\section{THE SECOND BATTLE OF YPRES}

THE ONSET : THE POISON GAS

THE deeds of April, I9I5, have written the name of Ypres in letters of blood upon the page of Canadian history, just as that name was already written imperishably in the annals of Great Britain. The first great attack in force of the Germans upon the Ypres salient in October, I9I4, had been made with the utmost determination. But for the quality of the British troops of the "little old Army," the onslaught of the Prussians should have been overwhelming; it was a bloody and desperate combat. Some 600,000 of the enemy were engaged against one quarter that number of British troops. So confident were the Germans of success, that, instead of concentrating on one action, they attempted to break through the thin, scarce-established line of the Allies in Flanders in several places simultaneously -in the far north at Nieuport, to the north and south of the Ypres salient, and at the southern extremity around Arras. While the fierce attack was being nobly repulsed at Arras by Maud'huy and his brave French battalions, and the Belgians protected the northern area by opening the dykes and drowning the oncoming enemy, it was round 


\section{WAR STORY OF THE C.A.M.C.}

Ypres that the British Army held on day after day with no reserves worth mentioning, with cavalrymen and camp orderlies and cooks. in the trenches side by side with the infantry, with a pathetic lack of guns, but with a determination never more grim.

Throughout the winter the city had been shelled from time to time. The Cathedral, the Cloth Hall, one of the finest examples of municipal Gothic architecture in Europe, and the other public buildings, had suffered heavily; but many of the ordinary houses were still untouched and the stores and inns, or estaminets, were not merely open, but thriving, conducting a busy trade with the soldiers billeted in and around the old city.

On April I9th, I9I5, the enemy began the intensive bombardment of the city, and with it the Second Battle of Ypres, pouring in heavy, large calibre shells, which.wrought great havoc upon the buildings, although, considering the size and density of the population of the city (about twelve thousand of the inhabitants still remaining), there were that first day few casualties, some fifteen children being killed in the streets, but no soldiers-and soldiers abounded. On the 2oth began the exodus of the inhabitants. They poured out along the main road to the west through Vlamertinghe, and past our Main Dressing Station of the 3rd Field Ambulance, and along the Furnes road through Brielen, past the headquarters of the A.D.M.S.-old men and women old and young, and little children, with their household possessions in every form of vehicle, down to perambulators and wheel-barrows and little carts drawn by dogs, and with bundles on their backs and in their hands-a piteous procession. 



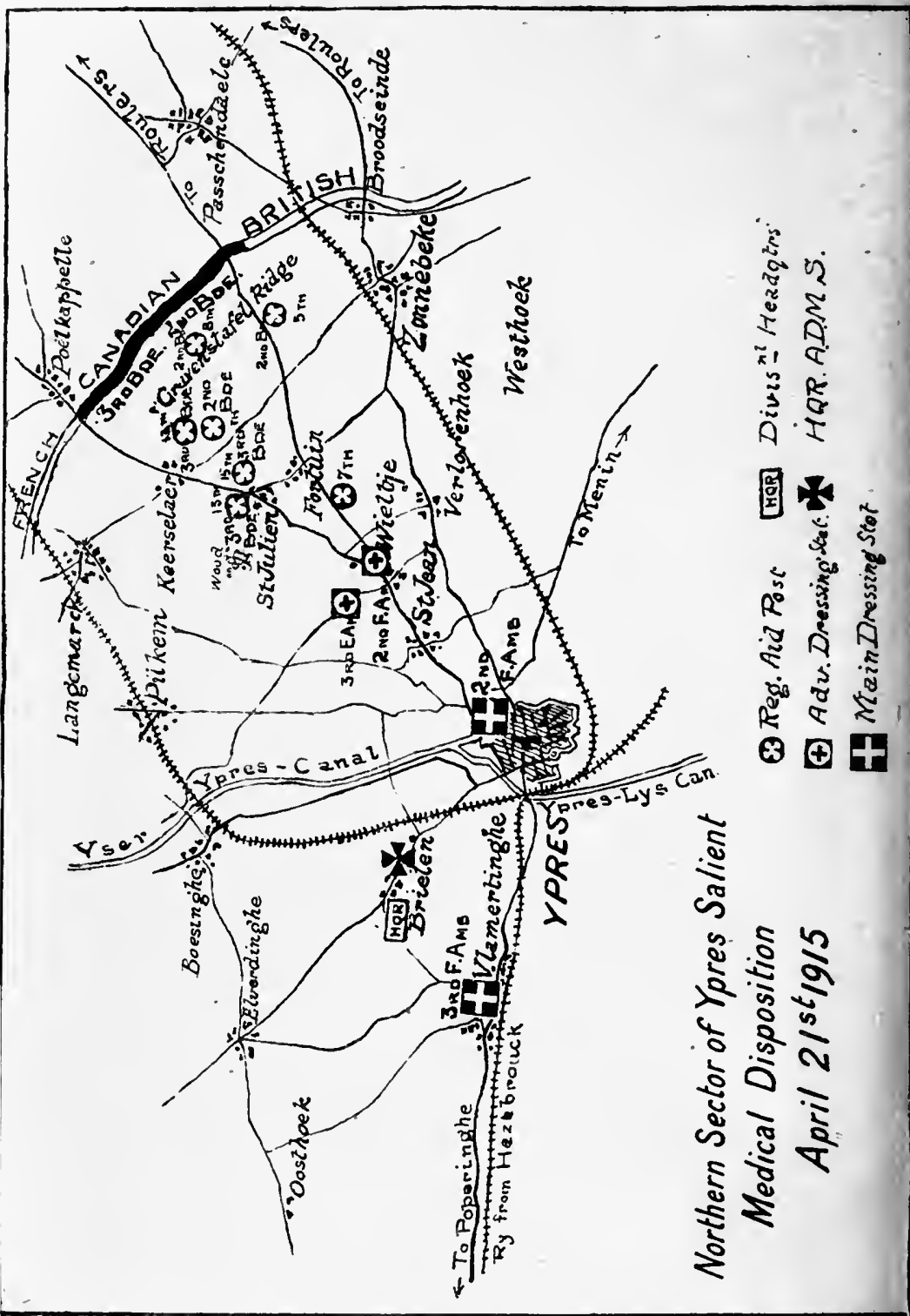




\section{THE SECOND BATTLE OF YPRES}

On the 2Ist the bombardment had reached such an intensity that it was deemed advisable to evacuate all the Main Dressing Stations in the city, and that evening all the British Field. Ambulances moved out. With them went two sections of the 2nd Canadian Field Ambulance from the M.D.S. at the north-eastern edge of Ypres, to the billets previously occupied by the 3 rd Field Ambulance at Oosthoek some ten miles away, one section being left to carry on an Advanced Dressing Station under Major Hardy.*

To those accustomed to map reading, the accompanying plan of the northern Ypres sector should indicate, we trust adequately, the position of the Canadian front and the disposition of the medical posts and stations at the beginning of the battle; nor for them will any further description be necessary. To those unaccustomed to the transla-

* Afterwards Lieutenant-Colonel, D.S.O. and O.C. 2nd Field Ambulance (now on duty in Canada).

Judged from the Diary of the unit the move was timely. The O.C., Colonel D. W. McPherson, writes: "Monday, April I9th.-At I I a.m. shells fell in Ypres, close to our dressing station; shrapnel and pieces of shell fell at irregular intervals. April 2rst.-Heavy shelling all morning; about a dozen casualties among the troops near our Dressing Station; none in our own unit. Men ordered in unless on duty, and to lie down flat when shells heard coming; this undoubtedly saved some of our men. 4.30 p.m. : By order of A.D.M.S. 'B' and ' $C$ ' sections were removed from Ypres, it being almost untenable, and proceeded to Oosthoek and bivouacked there. 'A' section, under Major E. B. Hardy, with Captains J. J. Fraser, D. H. Macdougall and E. G. Doe (Chaplain), remained at the D.S. in Ypres with three motor ambulances and watercart. Friday, April 23rd.-7.45 a.m. : Major Hardy reports from D.S. in Ypres that they were under continuous shell fire all night, and that as soon as he could evacuate all the wounded he was going to move the D.S." 
tion of military maps it will be serviceable to describe these dispositions. Briefly, then, on the evening of the 2Ist the and and 3 rd Canadian Brigades occupied a front of about two and a half miles, some four and a half miles to the north-east of Ypres, the 3rd Brigade (under Colonel R. E. W. Turner) being on the left in touch with a French Colonial Division, the and Brigade (under Lieutenant-Colonel A. W. Currie) on the right, here continuing the British line. Or, as Major Mothersill expresses it: "The trenches ran in front of the Gravenstafel ridge and the right flank was close to the tip of the salient." The nature of this front sloping gently down to the trenches, coupled with the fact that the enemy being on higher ground dominated it, rendered the position of the aid posts a matter of some little difficulty. When the Canadians took over these were all at some little distance from the front. Two of those of the 3 rd Brigade were in St. Julien village almost two miles away, entailing very long carries. While those of the 2nd Brigade were nearer, they were still in the estimation of the regimental medical officers at too great a distance; hence Major Mothersill brought his forward on to the top of the Gravenstafel ridge, and Captain Hart his to a point just on the Ypres side of the slope.* The 's Gravenstafel, or Gravenstafel ridge, rises very gently out of the plain to a height of twenty to twenty-five feet

* It is instructive to note that in this advanced position Major Mothersill, M.O. of the 8 th, was wounded on the second day of the engagement, and that his successor in the post, Lieutenant J. A. Stenhouse, R.A.M.C., of the Durhams, was taken prisoner; and again that, as will be described more fully

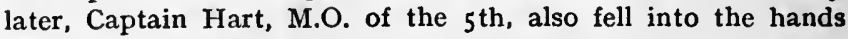
of the enemy. 


\section{THE SECOND BATTLE OF YPRES}

above the general level from Broodseinde to a point some three-quarters of a mile east-north-east of St. Julien. The roth Battalion of the 2nd Brigade and the I6th Battalion of the 3rd Brigade were in reserve. The Advanced Dressing Station of the 2nd Field Ambulance was at the road junction in the little village of Wieltje, that of the 3rd in some farm buildings about three-quarters of a mile to the north-west of the village. The Main Dressing Station of the 2nd Field Ambulance was, as just remarked, until this evening in Ypres itself (at the north-east corner of the city), that of the $3^{\text {rd }}$ Field Ambulance was established in the girls' school at Vlamertinghe, some two miles to the of Ypres on the main Poperinghe-Ypres road. Under normal conditions these would have evacuated their patients by ambulance convoy to the Casualty Clearing Stations at Poperinghe; but Poperinghe itself was within the zone of shell fire, and, indeed, soon received attention from the enemy, so that the Casualty Clearing Stations were moved further back, and evacuation had to be by motor ambulance convoys to Hazebrouck and Bailleul. The First Field Ambulance was not on the scene; it was conducting a Divisional Rest Station at Watou, some eleven miles to the of Ypres.

Thursday, April 22nd, was like a warm day of Indian summer in Canada. It had been absolutely cloudless, with a faint haze and light breeze, which veered round to the north-east. Throughout the day there had been no special activity in the trenches in the matter of shelling, although one after another the big German shells roared over the Canadians there with the sound of a passing train. 


\section{WAR STORY OF THE C.A.M.C.}

The men spoke of them as the "Wypers* Express." As on the two previous days, there had been abundant traffic along the Poperinghe road, old and young continuing to pour out with their household goods, and, as on those two days, there was the dull roar of explosions as shell after shell fell into the near-by city. Throughout the Canadian area the fine weather and the relative inactivity had led to not a little paying of "afternoon calls" in the different dug-outs and quarters.

It was towards seven in the evening that the officers of No. 3 Field Ambulance at Vlamertinghe, called out from an early dinner to witness the shelling of a couple of overhead Taubes, which were dropping star shells, $\uparrow$ noticed an unusual commotion along the road. Refugees were pouring along wildly, and soon, mixed among them, were Algerian soldiers. The Germans, they said, had used some terrible green gas and were following

* I venture to suggest that this is not a modern solecism, but is the old established English rendering of the name of the city. And that because otherwise I fail to see how the word "diaper" came into existence. "Diaper," it may be pointed out, is the outcome and English version of "Toile d'Ypres," the fine (linen) cloth with regularly repeated small and simple geometrical pattern, for which the town was celebrated throughout the Middle Ages. Readers of "Pickwick" will remember Sam Weller's recommendation to the Judge to "Spell it with a 'wee,' my Lord." Now we pronounce the letter " $Y$," as if it were spelt with a preliminary "Wee"-i.e., as "wy," and so did our forebears. "Diaper " cannot have been evolved from "d'eeper" or even " d'yper," but must have developed out of " de Wypers," the "wee," like the Greek lost letter "digamma," fading out, but leaving evidence of its previous existence, in the continuance of the two successive vowels sounded separately.

Chaucer, in his " Prologue," and in the "Wife of Bath's Tale," so introduces "Ypres" as to show that in his time it was pronounced as of two clear syllables.

$\dagger$ To direct the German artillery fire. 


\section{THE SECOND BATTLE OF YPRES}

after it ; they had broken through the line and all the guns were lost-and, as if to confirm the tale, teams of artillery horses came along harnessed, but without guns or wagons. Within an hour Turcos (Algerian troops) were pouring into Brielen, and the M.D.S. at Vlamertinghe, " a motley crew, the greater part not wholly clothed, and all minus their equipment;"* not one of them wounded, but haggard and in agony as the results of having been " gassed."

They staggered in, weak and semi-stuporose, with bloodshot eyes and hacking cough. Some had attacks of vomiting; all had an intense dyspnœa, rapid heart-beat, and the severer cases a ghastly ashy colour of the skin. The acrid odour given off from their clothes was so powerful that it affected the officers and orderlies who attempted to alleviate their distress, bringing tears to the eyes with smarting. $\dagger$

* Captain (now Major) G. G. Greer, now D.A.D.M.S., 4th Division, M.C. M.O. 2nd Battalion.

$\dagger$ Some forty were thus treated at the M.D.S. 3rd Field Ambulance, two hundred at the A.D.M.S. Office at Brielen, and large numbers at the Aid Post of the 14th Canadian Battalion, which was billeted, in reserve, in Vlamertinghe. This Aid Post was in an old convent between the Mill and the Church, which; I learn from Lieutenant-Colonel $\mathrm{R}$. Raikes, had originally been a manor house of the ducal family of de Montmorenci. By nightfall this was crowded with gassed Turcos from the front and wounded civilians from Ypres. The 2nd (Eastern Ontario) Battalion was also in reserve in Vlamertinghe, with a little dressing station on the main street. This also was busily employed. On account of the difficulty in obtaining names and other particulars from the Turcos, they were not entered in the Admission and Discharge Book. The majority left as walking cases; the remainder were sent by ambulance to Poperinghe, where the French had a station for their walking wounded. 
It was another three hours or so-hours marked by the hurried departure of many of the villagersbefore the wounded began to struggle in to Vlamertinghe, they, too, reeking of the gas; from now onwards without a break for many days, the personnel of the ambulance was kept working at the highest pressure. This was the beginning of a week of ceaseless activity in the ambulances, night and day.

The story we know so well was gathered together piece by piece : how, about five o'clock in the afternoon,* in front of the French line to the Canadian left there appeared, rolling along the level ground, a dark-green cloud, yellow where the light caught it, broken here and there by the black of exploding shells. $\uparrow$ In a few minutes Turcos, without weapons or accoutrements, were staggering dazed through out artillery lines behind St. Julien, and with them Belgian hares in large numbers, running in front of the gas and evidently affected by it, as they could be knocked over with scarce an effort on their part to escape. $\ddagger$

* Only thosc who have studied a serics of independent contemporary reports of a given event, made by absolutely conscientious observers-a set of War Diaries, for example-can realize how difficult it is to reconstruct the exact sequence of happenings. The hour of the gas attack is given by different observers as having been from a little after four o'clock to somewhere between five and five-thirty. A little after five o'clock best harmonizes with accounts given from bchind the front.

+ Seen laterally, or obliquely, as by most of the Canadian troops, this appeared to be unbroken ; seen from in front, as by some of our artillery, it was in "blocks" with clear intervals. between.

$\ddagger$ One cook in the Canadian Artillery knocked down our in a few minutes. 


\section{THE SECOND BATTLE OF YPRES}

Lieutenant-Colonel Nasmith was one of the first, if not the first, to advise Headquarters as to the nature of this gas-I quote from the Diary of No. 5 Canadian Mobile Laboratory-which those who know this able sanitarian will recognize as wholly characteristic : "Merville, 22.4.I5. Worked till midday, and then left with Captain Rankin for Ypres to get a man named Bethune, who had been transferred to us from No. 2 Field Ambulance. At Ypres evidence of recent shell fire apparent. Draper's shop where I had dined the previous Saturday had been struck with a $\mathrm{I} 7$-inch shell and had disappeared. No troops about the city. Went to H.Q. at Brielen to find Colonel Foster. . . . Drove back to Ypres and got samples of water from the swimming pool-of dirty water now being used as a source of supply: twenty-five carts waiting to be filled. Drove out to A.D.S. at Wieltje, and was delighted to find Captain Scrimger, M.O. of the Ioth, there. After a chat, got out of the car, which could not go any further towards the trenches, and walked up the road for half a mile to see what it looked like. As we went along we saw to the left of the road, about four miles away,* a long cloud of dense yellowish-green smoke rising and drifting in our direction. This cloud was apparently on a front of at least three miles, and started somewhere in the district where we knew the Canadians were, and covered the line occupied by the French towards Bixschoote. We agreed that it was in all probability the poisonous gas which we had heard that the Germans talked of using. It resembled chlorine in general appearance, but occasionally we could see brownish fumes

* More accurately some 6,000 yards.-J. G. A. 


\section{WAR STORY OF THE C.A.M.C.}

rolling over with it.* The cloud looked at least thirty or forty feet high. A violent artillery duel began in the region occupied by the French and gradually spread along the section occupied by the Canadians. The gas reached us within half an hour, and we diagnosed it as largely chlorine, but with probably some bromine present. Our eyes became bloodshot and ran water, and my throat became sore (subsequently my throat cleared up and a slight bronchitis appeared). There seemed to be another irritating gas present, but we agreed it was probably explosive fumes. .... General Alderson, G.O.C. Canadians, and Brigadier-General Burstall came up the road, the former stopping to shake hands. ... Somewhere about six o'clock the Canadian Artillery all around us began very rapid fire, and we realized the situation was growing more serious. Red Cross French passed up the road from St. Julien, and stopped to complain of the effect of the poison gases on their lungs. The first wounded Canadian came up in a cart from St. Julien, and a Canadian Highlander on foot, and black with powder and grease, said they had been left in a corner when the French retreated; that they had been surrounded by Germans. ... French Algerian soldiers came running across the fields towards us. . . . We decided to move back. Wieltje was crowded with refugees and wounded. We picked up three and brought them along to Ypres.

"All along the road we met Canadians coming

* Major D. A. Clark (now Lieutenant-Colonel and A/D.D.G.M.S. at Ottawa), who was through Ypres as M.O. of the 3 rd Canadian Artillery Brigade, to whom I am indebted for not a little insight into the happenings during the battle, explains these darker "puffs" as due to shells exploding. 


\section{THE SECOND BATTLE OF YPRES}

up and saw them advancing across the fields in skirmishing order, ${ }^{*}$ in one case their captain walking ahead swinging a bamboo cane. ... At No. 2 Field Dressing Station (Wieltje), already smashed by shrapnel, they were patching up one of their men who had been wounded outside in the street. A bursting shrapnel bent in the metal body of the car while we were (at Ypres). The shelling of Ypres was something terrific. (We delivered our three wounded men at the A.D.S. of the 2nd Field Ambulance, receiving in exchange a more seriously wounded man, whom we took on to Vlamertinghe.) Roads blocked with refugees and transports ... transports going up and refugees and French going down. Canadians drawn up all along the road. ... Ypres on fire behind us.

"Stopped at Poperinghe by irate British major, who complained that Canadians (convoys) insisted on going up and down the road-and what should he do ? We told him it was not our business, but advised him to leave them alone, as there was a big battle on, and they knew where to find their units. ... Reached laboratory at midnight and plated samples.

" 23.4.I5. Wrote G.H.Q. direct, to save time, about chlorine and bromine gas which we had diagnosed at Ypres. Suggested the use of a pad soaked in hyposulphite of soda to protect the men, and suggested that the enemy probably already

* This, Lieutenant-Colonel A. Rankin tells me. was near Wieltje ; they were reserve companies of the 2 nd or 3 rd Brigade, which deployed on either side of the road. Sentences between brackets indicate modifications in Colonel Nasmith's account, where that has been amplified by Lieutenant-Colonel Rankin's report. 


\section{WAR STORY OF THE C.A.M.C.}

had one designed that might be obtained if search were made on the field.

" 24.4.I5. . . Was sent for by Sir Henry Rawlinson to tell what I knew about the gas used by the Germans at Ypres on the 22nd. Told him all I knew. Drew a sketch for him of what I thought must have happened, and was surprised to find it was exactly right. 4th Corps Bulletin at night stated that prisoners said gas was contained in long cylinders; that men operating them used special rubber clothes and masks, and that the gas was projected forwards through pipes-the gas was probably chlorine, the Bulletin added. . . .

" 26.4.r5. Were visited by the A.D.M.S. 4th Corps and several medical officers in the morning, all interested in the gas and its effects. In the afternoon General Sir Henry Rawlinson called with General Dallas and staff. The General again went into the question of the poison gas and methods for prevention, and then asked to have the work of the laboratory explained. We showed him everything, and he seemed quite interested. . . .

"28.4.I5. . . Sir William Herringham* came in to ask about poisonous gases. He said, after listening to what we had to say, that Professor Baker had agreed exactly with our findings. . . .

"29.4.I5. . . Have been able to obtain but very, few specimens of mosquitoes and no anophelinæ.

"30.4.I5. Had a lot of samples of water taken in the canals round to test bacteriologically, and see how they would be cleared by alum.

"I.5.I5. . . Took a letter of introduction

* Bart., LL.D.; late Dean of the Medical Faculty of the University of London; Consultant in Medicine at the front. 


\section{THE SECOND BATTLE OF YPRES}

round to laboratory where Professor Watson and his assistant, Mr. Jones, were working. . . . They had concluded that the gas used by the Germans was probably a mixture of chlorine and bromine, and had identified chlorine from the buttons of the coats of gassed soldiers. . . Interested to note that my diagnosis of the gas was correct, and also that the respirator and solution advised was the one being used."

One more note may be added from the diaries regarding the effects of the gas. Describing its employment against the 2nd Brigade on the right flank on the morning of the 24th, Major Mothersill notes: "Fortunately the supply was not unlimited, and after the gas cloud passed over, most of the men soon recovered from its effects. But there were others who lay in a condition of collapse. . . . Once a man falls from the effect of the gas he usually soon collapses, due to the increased concentration at this slight difference of level." This is only what might be expected from the fact that chlorine is so much heavier than air. Lieutenant-Colonel Nasmith makes a similar observation (May 3rd, I9I5): “... At Ypres certain wounded men had been collected into dug-outs and left breathing easily; later on they were found dead, presumably from breathing the residual chlorine left in the trenches."

Lieutenant-Colonel Rankin tells of a dog that came loping past them outside Wieltje in evident distress, with tongue hanging out and a most expressive look, as though to say: "What fools you are to remain when you can get out of this." The heavy nature of the gas, whereby the nearer the ground the greater was its concentration, made 


\section{WAR STORY OF THE C.A.M.C.}

it particularly deadly for small animals. Further experience, indeed, has demonstrated that not merely does it reduce materially the live stock of dug-outs, but it has a-for human beings-beneficial influence in destroying the parasites of that most irritating and most humiliating skin diseasescabies. 


\section{CHAPTER VI}

THE SECOND BATTLE OF YPRES-(continued)

\section{THURSDAY AND FRIDAY}

\section{EPITOME OF MILITARY OPERATIONS}

Thursday, April 22nd.

5 p.m. Gas attack on French lines to left of Canadian lines. Canadian left flank also affected. On extreme left $5_{5}$ th Canadian Battalion gave way temporarily, but recovered its ground; I $3^{\text {th }}$ Battalion next to it held its ground. French Colonial troops gave way. Canadian left " in the air."

to Colonel R. E. W. Turner, commanding 3rd Brigade, extends his left at right angles as far as the wood east of St. Julien. Is attacked by four German Divisions. Enemy attempts to work round Canadian left flank; seizes St. Julien Wood; crosses Canal north of Boesinghè; digs himself in from Boesinghe to north of St. Julien.

$7_{\text {th }}$ and roth Canadians (2nd Brigade) come up Midnight. in support of 3 rd Brigade, as do also 2nd and 3 rd (Ist Brigade) and I6th (3rd Brigade).

Friday, April $23 r d$.

Midnight Ist and 4th Canadians (Ist Brigade) come up out of reserve, advancing across Canal towards to Pilkem. They are joined to Geddes's Detachment (companies of several British battalions)

a.m. As part of Geddes's Detachment they help to fill in breach between the French and the roth and 16 th around St. Julien. 


\section{WAR STORY OF THE C.A.M.C.}

4 a.m. Ioth and I6th counter-attack and retake St. Julien Wood. Gas attack against 2nd Brigade on right flank of 3 rd Brigade. Second advance of Ioth against German trenches being constructed opposite their front. Death of Colonel Boyle.

6 a.m. Attack by $4^{\text {th }}$ Canadians, with ist in support, against German shelter trenches to north of Ypres. Death of Colonel Birchell, of $4^{\text {th. }}$ German trenches seized and occupied. 8th Battalion expelled from trenches by gas attack ; counter-attacked, retaking trenches and bayonetting enemy.

Afternoon. Colonel Hart McHarg, of $7^{\text {th }}$, mortally wounded opposite Keerselaere. 3rd Brigade reinforced by 2nd King's Own Scottish Borderers and Ist Royal West Kents. Retirement of 3rd Brigade to line on this side of St. Julien, leaving there detachments of $13^{\text {th }}$ and 14th Canadian Battalions. Major-General Currie extends his left flank at right angles.

IT is little wonder that those French "native" troops that had not been immediately overcome broke under so novel and terrifying an experience. What happened next is part of Canada's history which for generations to come will be known by every schoolboy : how, seeing the enemy advancing through the gap, Colonel (now Lieutenant-General) Sir R. E. W. Turner, in command of the 3 rd Brigade, finding the Canadian left " in the air," extended his left wing at right angles so as to flank the advancing masses of blue-grey Germans; how the 13th and r4th Battalions (Royal Highlanders of Canada and Royal Montreal Regiment) forming Colonel Turner's left wing, though thinned out by this extension, held their own, despite the furious onslaught of the enemy directed specially at the northern angle; how, in falling back, St. Julien Wood had to be evacuated, leaving four British guns in the posses- 


\section{THE SECOND BATTLE OF YPRES}

sion of the Germans ; how the 7 th (British Columbia) and the roth Battalions of the 2nd Brigade came to the assistance of the $3 \mathrm{rd}$ Brigade, continuing the southerly extension of the left wing until at nine at night reinforcements began to arrive from the Ist Canadian Brigade ;* how, shortly after midnight, instead of retiring before the enemy, the Ioth and r6th Battalions, under Lieutenant-Colonel Boyle (who fell some few hours later) and Lieutenant-Colonel (now Brigadier-General) Leckie, stormed gloriously and drove the Germans out of St. Julien Wood, recovering what remained of the guns; how the fighting continued all through that night and the next day-Friday-and days to come, and how by their fighting qualities the thin line of Canadian troops so mystified the Germans, with all their hordes, as to the strength of the troops opposed to them, that they did not venture to advance in the gap of more than a mile left between Canadians and French, although, had they known it, the only troops which for a day and more intervened between them and Calais was a single scanty line of Canadian artillery. What our artillery, under LieutenantColonel (now Major-General) H. E. Burstall, accomplished at this crisis deserves fuller mention and

* If I am not mistaken, the credit of being the first reserves to arrive belongs to the East Yorkshire Regiment (under Lieutenant-Colonel Seeley, who before the war had been Staff Officer at Toronto); but this, instead of joining on to the Canadian left flank, upon crossing the Canal marched north to drive the Germans out of Pilkem, and preserve the important Pilkem ridge (which again in the great Third Battle of Ypres, beginning on July 31 st, 1917, has been the scene of active fighting). Thanks to the simultaneous and unexpected advance of the Canadians through St. Julien Wood, they succeeded in their object, the Prussians withdrawing from the village. 


\section{WAR STORY OF THE C.A.M.C.}

recognition than has come to them. They certainly held a most deadly breach.

To turn to the medical arrangements.

All through this narrative of the Canadians at Ypres there must constantly be kept in the foreground the fact that we deal with men and with an administration previously untried in actual warfare, with a medical service of whose officers but three out of the fifty-nine belonging to the Ist Canadian Division overseas* belonged to the Permanent Medical Force, all the rest having been in civilian practice before the war, with but three officers (Major J. McCrae, Major D. Donald and Captain G. H. R. Gibson) who had been in action before (in South Africa); and, what is more, with men and an administration exposed to the severest test of all-a surprise attack in an area with which time had not been given for them to become familiar. In later engagements we shall see that the staff have issued operation orders detailing precisely the movements of the different units and the times for the same, the roads to be used, the lines of evacuation of the wounded. Thus for the medical service Ypres was to determine whether it had been developed along the right lines; whether the system which had been evolved in peace time during the last ten years would stand the strain; whether the separate parts-Regimental Medical Officers and Aid Posts, Advanced and Main Dressing Stations of the Field Ambulances, back to the A.D.M.S. and divisional staff-were so co-ordinated that without

* In this enumeration the officers of the rst Casualty Clearing Station are included as serving in the district at the time; the "Princess Pat's," R.C.D. and the K.G.H. are excluded as not belonging to the division. 


\section{THE SECOND BATTLE OF YPRES}

preparation they would carry on like clockwork? And, since system is always secondary to manpower, whether the officers directing the system, the administrative staff and heads of the different medical units, were the right men for their respective places, men who, directing the system, could rise superior to the difficulties encountered, could stand this supreme test. To these questions there can be but one answer: both men and system stood the test and abundantly proved their quality. If in the narrative that follows we have perforce to describe emergencies, it is either to show how these were forthwith overcome, or how through force majeure that happened which could not be guarded against. I do not say that the service is perfect; no human system is. I shall, in future chapters, show how time and again the experience gained at Ypres was utilized to render the Canadian Medical Service more supple, more prompt in its operations and more efficient. But this may confidently be said, that at Ypres, at a bound, that service showed itself completely competent; and, as in matters military the eventual responsibility for every action falls upon the Officer Commanding, so rightly the credit for the success of the Canadian medical operations at Ypres should before all be awarded to the officer who controlled those operations, Colonel G. L. Foster, A.D.M.S.*

* Colonel (now Major-General) Gilbert La Fayette Foster, C.B., D.G.M.S. Canadian Overseas Forces, is a Nova Scotian, the son of Mr. George Foster, of Kingston, N.S. He was born May 29th, 1874, at Kingston; graduated in Medicine at the University of New York in May, 1896; entered into practice at Canning, N.S., and Halifax, N.S. ; Visiting Surgeon, Victoria General Hospital, Halifax, N.S. Joined the Canadian Militia as Surgeon-Lieutenant of the 68th (King's County) Regiment 


\section{WAR STORY OF THE C.A.M.C.}

How, then, during this time was it faring with the medical arrangements? The two Advanced Dressing Stations at Wieltje were well prepared; No. 2, indeed, had all its bearers on the spot, together with three motor and three horse ambulances and a water cart. Its officers were just sitting down to an early dinner, when Turcos came pouring into Wicltje, and from that moment the dressing station was fully occupied. So flat and exposed is this region that, once the action began, it was not possible to push forward to remove wounded from the Regimental Aid Posts until nightfall. And at the R.A.P.'s conditions were strenuous. At the front the regimental stretcherbearers were doing valiant work, administering first aid under heavy fire, and at every opportunity carrying back to the R.A.P.'s. The enemy was shelling the roads so as to destroy communications and prevent reinforcements coming up. But, notwithstanding the shelling, the aid posts became full ; if, with nightfall, the R.S.B.'s could bring in the wounded from the trenches in greater numbers, so, too, the ambulances could advance up to the R.A.P.'s and evacuate them. And the ambulances were kept busy throughout the night. With the retreat of the French Colonial troops from the line between Pilkem and St. Julien, the A.D.S. of the 3rd Field Ambulance, situated some three-

in 1896 (the Hon. Sir Frederick Borden being Surgeon); served two years in Yukon Field Force (during South African Campaign), 1898-1900, and in 1905 joined the Permanent Army Medical Service, becoming A.M.O. 6th Divisional Area, Nova Scotia, I9II ; A.D.M.S. 2nd Divisional Area (Toronto), I913 ; Captain, 1901 ; Major, 1902; Lieutenant-Colonel, 1907; Colonel B.E.F., 1915; D.M.S. and Surgeon-General February, 1917 ; Major-General and D.G.M.S., O.M.F.C. 1918. 


\section{THE SECOND BATTLE OF}

quarters of a mile to the north-west of Wieltje in farm buildings behind the Brigade Headquarters, became not only exposed, but also non-effective. Captain J. D. McQueen* therefore moved without delay into Wieltje, to be in the direct line of communication and to assist the 2nd Field Ambulance in the care of the wounded. He reported many wounded lying in the field, and, employing his bearers, performed notable service in organizing their removal. At dusk Major Templeton $\uparrow$ proceeded with motor and horse ambulances and abundant medical supplies to his assistance. The motor ambulances during the night of the 22nd-23rd made four complete trips from Vlamertinghe to Wieltje and back.

But while thus the wounded poured in from the trenches, the collection of those wounded lying on the field became increasingly difficult. It was a pitch-dark night. Captain E. R. Brown, $\ddagger$ of the I3th Battalion, who had with him the stretcherbearers whom he, as M.O. of the 5th Royal Highlanders (Montreal), had trained for five years and more, of whom he was justly proud, tells of the difficulties of this night. So dark was it that he and his sergeant, Bell, at last took between them the road from their R.A.P. at St. Julien towards Poelcapelle and the front, the one walking on the one side, the other on the other, shouting as they went: "Any wounded here." Nor were they unrewarded, since arriving at the artillery lines they found these on the point of being evacuated,

* Now Lieutenant-Colonel, D.S.O. O.C. King's Canadian Convalescent Hospital, Bushey Park.

$\dagger$ Now Lieutenant-Colonel, D.S.O. Later O.C. No. 3 Field Ambulance, and now D.A.D.M.S. Ist Canadian Division.

‡ Now Lieutenant-Colonel and A.I.D. Etaples area. 


\section{WAR STORY OF THE C.A.M.C.}

and an officer with a shell wound and fracture of the knee, who, conveyed there upon an extemporized stretcher of corrugated iron, was so effectively wedged into a dug-out that his company feared to extricate him. He succeeded in getting him out and back, replacing the corrugated iron sheet by another more portable extemporized stretcher, namely, a wicker hurdle.

By midnight the shelling of Wieltje had become so severe that it was necessary for the A.D.S. of the 3 rd Field Ambulance to move back and occupy an estaminet in St. Jean. We shall, in the course of the narrative, become accustomed to this story of Advanced Dressing Stations being shelled out and forced to find new positions. Of necessity, they are within the zone of abundant shell fire-often at the same level as our artillery lines, so that they are peculiarly liable to be sought out. But they seem to bear a charmed life.

The first night of the battle the casualties were very heavy, nor was there any sleep for any of the Canadian Medical Service. Although well provided with motor and horse ambulances, these were insufficient, and Motor Ambulance and Red Cross convoys helped in evacuating the A.D.S.'s back to Vlamertinghe, where the M.D.S. of the 3 rd Field Ambulance handled most of the cases until early the next morning. Describing this time, LieutenantColonel Watt writes: "One never-ending stream which lasted day and night for seven days without cessation: in all some five thousand two hundred cases passed through our hands. Wounds here, wounds there, wounds everywhere. Legs, feet, hands missing ; bleeding stumps controlled by rough field tourniquets; large portions of the abdominal 


\section{THE SECOND BATTLE OF YPRES}

walls shot away; faces horribly mutilated; bones shattered to pieces; holes that you could put your clenched fist into, filled with dirt, mud, bits of equipment and clothing, until it all became like a hideous nightmare, as. if we were living in the seventh hell of the damned."

But with all this apparent chaos there was underlying order. The Main Dressing Station of the 3rd Field Ambulance at Vlamertinghe was admirably adapted for its work. Provided with a spacious courtyard, ambulances poured in at one of its gates in rapid succession. "Stretcher-bearers detailed for the work rushed up and emptied them, laying the patients carefully in the courtyard, and without confusion the emptied ambulances passed out through the other gate, back to be refilled at the A.D.S. Other stretcher-bearers carried the patients into the operating-room, where four stretcher and eight sitting cases were attended to at the same time by the surgeons in charge. And, after being dressed, they passed into the next ward, where every patient, unless his wounds contra-indicated, received a hot meal and, when able to smoke, a cigarette; thence into the adjoining wards to rest until summoned to begin the next stage of the journey back to the base." . . . " And so the work went on, and when the accommodation would be taxed to the utmost--when the courtyard would be full of those waiting for admission; " when adjoining houses were used up; when even the billets of the men of the unit were requisitioned and it seemed impossible to take another patient, the welcome Red Cross convoy would appear. Ambulance after ambulance would be filled, every man checked as he was evacuated, and as soon as 


\section{WAR STORY OF THE C.A.M.C.}

full, off it would purr to the Clearing Station away in the rear. Thus the work went on hour by hour and day by day, until finally at the end of the seventh day this huge total of wounded had passed through our hands."

The clearing of the wounded was at times so urgent that, as on the 23rd, everything was used for transport-horse-drawn vehicles, motor lorries, London omnibuses, village carts and gun limbers. Regarding the critical times on the 23rd, Colonel Foster, the A.D.M.S., writes: "I cannot speak too highly of the assistance rendered to the Field Ambulances by the Motor Ambulance convoy and Red Cross people. When a large number of sitting cases or slightly wounded are brought in, a motor omnibus can handle these satisfactorily, and is a great saving upon the motor ambulances proper."*

The little Ford car belonging to the 3rd Field Ambulance was pressed into service, and in connection with it occurred a ghastly episode which has burnt itself into the memory of all beholders. Early on the morning of the 23rd it was returning from Wieltje with two slightly wounded officers, when outside Ypres a shell fell immediately behind it. The body of the car was riddled by fragments, and the driver, Sergeant J. G. Kinsell, was badly wounded in the head. He was brought into the M.D.S. suffering from shock. A driver was later sent to retrieve the car, and finding that it could still be run, he brought it on to Vlamertinghe and into the courtyard of the M.D.S., bringing the

* Lieutenant-Colonel F. C. Bell tells me that on one occasion, when the M.D.S. was packed to overflowing, some 440 " sitting cases" were evacuated at one time by the opportune arrival of motor 'buses, which had been used to bring up fresh troops to the front, were returning empty, and were promptly commandeered ! 


\section{THE SECOND BATTLE OF YPRES}

battered car to a standstill at the hospital door. Apparently the force of the explosion had exerted itself just over the top of the car. There sat the two officers, rigid, each in a perfectly natural position, but headless, or, what was yet more awful, the one completely headless, the other with face blown off, the back of the head flapping to and fro with each jolt of the car. There is scarce a campaign but has afforded similar instances of the immediate onset of cadaveric rigidity in those who have undergone hours of intense effort. No one who has seen such a case can ever forget it.

But to continue the orderly chronicle of events. The severity of the attack, once it was developed, and the number of casualties indicated the need of more Main Dressing Stations, and this at the most advanced points possible behind Ypres, namely, at Vlamertinghe and Brielen.

Early upon the morning of Friday, the 23rd, the Ist Field Ambulance, under Lieutenant-Colonel A. E. Ross, was brought into Vlamertinghe, establishing an M.D.S. in a large and roomy house adjoining the girls' school occupied as M.D.S. by the 3 rd, as few of the officers and men as could be spared being left behind at Watou to continue running the Rest Station at the convent.*

It will be recalled that the M.D.S. of the 2nd Field Ambulance at Ypres had been disbanded, leaving but one section there under Major Hardy. That one section stood it out bravely throughout

* Throughout the days immediately preceding that, the greater part of this unit had been marching and countermarching. Thus the unit reached Watou on the 17 th ; on the 2oth two of the three sections were ordered to Oosthoek, near Elvertinghe and on the 2 ist were recalled only to have the Bearers return to Oosthoek on the 22nd. 


\section{WAR STORY OF THE C.A.M.C.}

the night of the 22nd-23rd, when shells were raining upon the doomed city. Big shells fell constantly around the D.S. Nevertheless, although seven of the personnel received wounds, some three hundred patients were dressed and evacuated. The shelling at this northern end of the city appeared to be directed especially upon the road and bridge over the Yser Canal, which formed, as it were, the spout of the funnel draining the northern part of the salient forming the field of battle. Our ambulance men ran the gauntlet each time they passed along this portion of the road and round "The Devil's Corner." By ten o'clock the next morning the Dressing Station in Ypres was no longer tenable. Leaving it, Major Hardy established his section for a few hours at the cross-roads outside Ypres, and in the afternoon was ordered to take it to the Schoolhouse in the east end of the straggling village of Brielen, there to join Major D. B. Bentley, ${ }^{*}$ in charge of B Section, who, during the forenoon of this day, had opened up a Dressing Station here to serve the East Yorkshire Regiment and, other British troops across the Canal. Later this same afternoon Major A. E. Snell, $\uparrow$ with C Section of the ambulance, was directed to establish another Dressing Station at the Red Château to the south-east of Brielen, to serve the Reserve troops in the neighbourhood of the Canal, north of Ypres, and receive the wounded who were being collected by the bearers of the Ist Field Ambulance, under Captain Stone.

To understand what was happening at this period

* Later O.C. Canadian Convalescent Camp, Monks Horton, Kent, and O.C. Base Depôt Medical Stores, Sonthampton. Died April 5th, I9I7.

† Now Colonel, C.M.G., D.S.O.; A.D.M.S. 3rd Division. He has been mentioned in Dispatches five times. 


\section{THE SECOND BATTLE OF YPRES}

on the Canadian left, it is necessary to enter into some little detail. With the hurried retreat of the French Colonial troops a big gap was left upon our left-how big, it would seem that the enemy did not realize. If the Germans could advance through this gap they could turn the Ypres position. To arrest them the Ypres-Yser Canal occupied potentially a very important defensive position. It was all-essential that this should be defended.* The 7th (British Columbia) Battalion, belonging to the 2nd Brigade and in reserve, had first come up to the aid of the 3rd Brigade. Next the Ioth and r6th Battalions of the 3 rd Brigade, also in reserve to the north-east of Ypres, coming up extended the Canadian left still further. At 9 p.m. that Thursday night the Ist Brigade was put in motion, the 2nd Battalion moving out of Vlamertinghe through Brielen, so over a pontoon bridge across the Canal through St. Jean and Wieltje to a position in support of the Ioth and r6th. They were followed by the $3^{\text {rd }}$ Battalion, and these by a force made up out of several regiments and known as Geddes's Detachment, to which was joined the Ist and 4th Canadian Battalions, coming up hurriedly out of reserve. $\uparrow$ And early on Friday morning these Canadian troops, under General Mercer, in association with the rest of Geddes's Detachment, under

* As a matter of fact, further to the north in the French lines from this side of Boesinghe to the other side of Lizerne, the enemy succeeded in crossing it on Friday, bringing up reinforcements; our Allies eventually forced them back during the course of the next seven days.

$f$ As already noted, the $4^{\text {th }}$ (Central Ontario) Battalion had been billeted in Vlamertinghe. They moved out at I.30 a.m., and, marching through Brielen, crossed the Canal there, and at 4 a.m. were in action over against Pilkem. 


\section{WAR STORY OF THE C.A.M.C.}

the cover of the guns of the Ist Canadian Artillery Brigade, began a counter-attack upon the trenches into which the enemy had hastily dug himself to the north of Ypres. The Aid Posts of the Ist and 4th Canadian Battalions were installed in a farmhouse to the west of the Pilkem road, and at 4.30 a.m. the first wounded came in. That attack was made against terrible odds. It will be remembered how the death of their beloved O.C. (Lieutenant-Colonel Birchell) while leading them, led the 4th (Central Ontario) Battalion to avenge that death bloodily, bayoneting the last German who resisted, capturing the trenches and holding them through Saturday and Sunday. But the success was against enormous odds and the casualties were correspondingly great. They came out one quarter the number that went forward from Vlamertinghe in the dark hours of Friday morning.

Here it will be well to note some of the doings of the ist Field Ambulance, and follow the movements of Captain E. L. Stone.* On the Thursday its bearer section had been marched by the O.C., LieutenantColonel Ross, to Oosthoek, near Elverdinghe, there joining the two sections of the and Field Ambulance that had been brought back from Ypres. Early upon Friday the 23rd, Major Duval and Captain McGibbon left with the ambulances to clear from the A.D.S. of the 2nd Field Ambulance at St. Jean. A little later Captain Stone and Captain C. R. Graham $\dagger$ left Oosthoek with all the bearer subdivision and wagons, in all some one hundred men,

* Now Lieutenant-Colonel and O.C. Canadian Special Hospital, Witley, after having been O.C. 15 th Field Ambulance.

† Now Major on the staff of the Granville Canadian Special Hospital. 


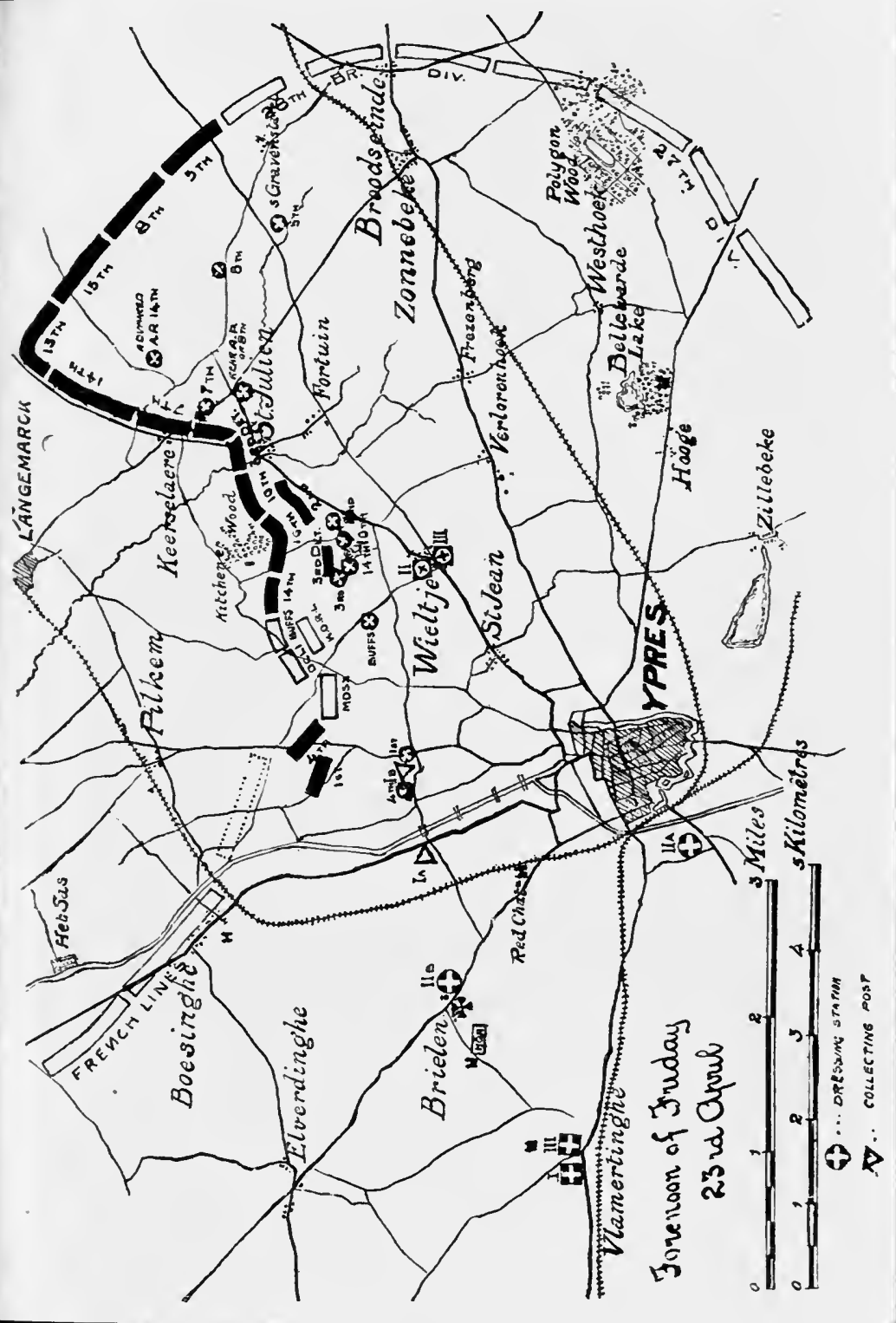





\section{THE SECOND BATTLE OF YPRES}

being directed to clear from the region of the Canal, and more particularly to collect the wounded of the Ist and 4th Canadian Battalions, resulting from the furious engagement then at its height. Marching through Brielen, they found a good road leading to the Canal, and close to the latter they cstablished a Collecting Post, with Captain Graham in charge. Thanks to the pontoon bridges, wounded to the left of our lines could be brought, if necessary, from the A.D.S.'s at St. Jean by a fairly direct route to Brielen. Even if the Germans were shelling all along the line of the Canal and searching out the pontoons, the crossing was better than running the gauntlet at the accurately registered "Devil's Corner." Captain Stone crossed the Canal, taking his bearers with him, and about ro a.m. established a Collecting Post in the farm, already mentioned, near the Pilkem road, where the R.A.P.'s of the Ist and 4th Battalions had been established since early morning. This was already under shell-fire, and just before his arrival a "tear shell " had entered one end of the house. At midday another lachrymatory shell rendered evacuation of the Collecting Post both imperative and hurried.* For a time he

* Major (now Lieutenant-Colonel) Raikes, who was M.O. of the $4^{\text {th }}$ Battalion, tells me that he managed to maintain his R.A.P. in these farm buildings until the middle of the afternoon, when the liveliness of the shelling forced him to evacuate. By that time the farm was as full of wounded as it could hold. No ambulance was able to reach him to evacuate his wounded, and he re-established his Aid Post in a shed on the west side of the Canal, adjoining an estaminet, the Headquarters of the Ist Battalion. This meant a long carry for his bearers. Here through the night he received splendid help from two chaplains, Major Beattie (now Head of the Chaplain Service in Canadal and Captain Gordon (son of the late Principal Gordon, of Queen's University, Kingston). 


\section{WAR STORY OF THE C.A.M.C.}

made his centre at the Collecting Post on the other side of the Canal, his men working up to the farm. By dusk the wounded ceased to come in, and now he heard of a large farm half a mile beyond the earlier farm, and on the other side of the Pilkem road. Advancing to take possession, he found it full of wounded, with no Medical Officer. It was, in fact, in charge of a corporal of an Imperial regiment of Geddes's Detachment, who had under him four or five men from different units. The wounded who filled the farm buildings were equally hetcrogeneous, men from Imperial troops preponderating. Captain Stone made this farm his Collecting Post. It would be improper to call this an Advanced Dressing Station : they were all too busy to do any dressings. There was no time to take notes and make records, they were fully occupied in looking after the creature comforts of the wounded-tagging them and sending them on. Between noon on the $23 \mathrm{rd}$ and 5 a.m.

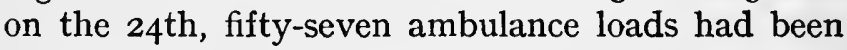
evacuated under his dircction. At Brielen that night, apart from the Red Château, the M.D.S. in the School-house, three estaminets and the nearby church were full of wounded.

Over against the 3 rd Brigade, with its extension leftwards, the fighting throughout all Thursday night was very bitter. It was about midnight, for example, that the and Battalion came into position, and casualties came in all the time. It was too dark to reconnoitre for a suitable Aid Post, and at first the casualties were dressed in the Field and sent to the R.A.P. at 3 rd Brigade Headquarters in what later became known as Shell Trap Farm. Eventually the O.C., Lieutenant-Colonel (now MajorGeneral Sir David) Watson, found Headquarters 


\section{THE SECOND BATTLE OF YPRES}

in a small farm of the usual Flemish type, and here the R.A.P. was established. No sooner was it established than men of the Ioth and I6th came pouring in, this being the Aid Post nearest to their front.*

St. Julien was heavily shelled; how brave a resistance was put up by Major McCuaig and the I 3 th is remembered by all Canadians. During the afternoon of Friday the increased intensity of the artillery fire of the enemy forced the devoted 3 rd Brigade further back, yard by yard, upon and then through St. Julien, leaving there (when the order came for the Brigade to retire) companies of those two brave regiments the I3th (Royal Highlanders of Montreal) and the I4th (Royal Montreal Regiment) to fight to the last, cut off hopelessly.

Through all the shelling of this area conditions at the Advanced Dressing Stations at Wieltje became more and more difficult. At noon on Friday, Major C. P. Templeton, $\uparrow$ of the 3rd Field Ambulance, sent back the message: "Simply unable to collect wounded until dark, as it is hell here. Have been shelled out of A.D.S. Will establish one further back this evening. Require stretchers and bearers." Now, stretchers for the moment were not too numerous, as many had been sent conveying French wounded from Brielen and Vlamertinghe to the French Field Ambulances at Elverdinghe and Poperinghe on the evening of the 22nd, and these were already so crowded that

* Some 150 of the 16 th and 125 of the roth passed through Captain Greer's hands at this post.

$\dagger$ Now Lieutenant-Colonel, D.S.O., D.A.D.M.S. 1st Canadian Division, after having been O.C. No. 3 Canadian Field Ambulance. Twice mentioned in Dispatches. 


\section{WAR STORY OF THE C.A.M.C.}

rather than place the wounded on the bare floor stretchers had to be left, nor could the French pattern stretchers be exchanged, as they were all in use. The lack was, however, remedied in a few hours : that evening there was no lack.

The A.D.S. of the and Field Ambulance maintained itself at Wieltje for some hours longer, until, with the loss of St. Julien and nearer approach of the enemy and his guns, it became folly to run further chances. At five in the afternoon Captain W. A. Burgess* reported thence that he was moving back to St. Jean with two of the unit wounded. The bearers of the and, one and all, manifested splendid skill and personal bravery. As the O.C. (Lieutenant-Colonel D. W. McPherson) writes with pardonable pride, theirs " was the worst section of them all to clear from, when the poisonous gases were first encountered. The men frequently placed the wounded in ditches, lying flat to avoid shells; where there was little protection, the wounded got the first choice. No wounded man received a second wound while in our charge. The three officers of this section, Captains Burgess, P. G. Brown $\dagger$ and McKillip, deserve the greatest of praise for their untiring devotion to duty." In this connection the services of Captain (now Major) McKillip $\ddagger$ were so outstanding, with so complete a

* Later Major 8th Field Ambulance; now on duty in Canada.

$\dagger$ Now Lieutenant-Colonel and O.C. No. 2 Canadian C.C.S.

$\ddagger$ Major G. G. Greer (then Captain and M.O. of the and Battalion), in his notes on the battle, writes : "The and Canadian Field Ambulance was clearing me, and I must say that their work under Captain McKillip and Captain Brown was most excellent. Captain McKillip established himself with his bearers near my post and worked unceasingly till Saturday 


\section{THE SECOND BATTLE OF YPRES}

disregard for his own safety and so great a care for the relief of the wounded, that he was later awarded the D.S.O. There will be occasion to refer to the good work of the other two officers later. What Colonel McPherson testified regarding his bearers might well have been said regarding the whole body.

Turning now to the fortunes of the and Brigade, forming the Canadian right flank, this throughout Thursday evening and night and the early part of Friday had been relatively neglected by the enemy. There was, it is true, a discharge of poison gas at dawn on Friday morning against the whole Canadian front, but from the lie of their trenches and the direction of the wind, this affected more particularly the Highlander regiments of the 3rd Brigade. Major Mothersill, M.O. of the 8th (Winnipeg) Battalion, on the extreme right, describes Friday forenoon as having been strangely quiet, with only an occasional shell dropped into the trenches, and but few casualties. On Friday afternoon, when the increased intensity of the artillery fire of the enemy forced the 3 rd Brigade backwards in the St. Julierı area, fighting every inch, with its withdrawal Colonel Currie had in his turn to repeat Colonel Turner's manœuvre of the

morning." (Major T. H. McKillip, D.S.O., after much service at the front with the 4th Division, is now on the Staff of No. 7 General Hospital.) "The casualties poured in all Thursday night, Friday, Friday night and Saturday morning. At one time on Friday I had over two hundred cases collected in the farmyard" (at his R.A.P.I; " but thanks to the admirable work of the Field Ambulances and the Motor Ambulanoe Convoy, they were all cleared safely. They did not shell me much until after this convoy came, but shelled it all along the road on the way up and going back. Then they commenced to shell my Aid Post with gas and shrapnel." 


\section{WAR' STORY OF THE C.A.M.C.}

previous day, and extend his left flank at an angle in order to keep in touch with the retiring Brigade. It was at this period that the 7 th Battalion (British Columbia) suffered heavily, losing their gallant leader, Colonel Hart McHarg, despite the care of Captain George Gibson, the M.O. of the regiment,* the battalion fighting on until it had been reduced to one hundred men capable of bearing arms. Regarding Captain Gibson, Brigadier-General (now Lieutenant-General Sir) A. W. Currie, in a letter of August I5th, I9I5, states: "I could -write pages of incidents in which he most gallantly participated. At Ypres, before the battle, when it was impossible to visit front trenches in the daytime without the greatest danger, Gibson always went if he heard of a case in urgent need of medical attention. No one ever thought of making the trip except Gibson. Then, during the battle itself he was splendid."

Hearing that his Colonel was wounded, Captain Gibson, under heavy fire, went to his assistance in the "No Man's Land" between the two forces on this side of Keerselaere, within two hundred yards of the enemy, accompanied by Sergeant J. Dryden. Regardless of personal danger, the two moved him out of a shell-hole to the shelter of a ditch, dressed his wound and, exposed, to shell and heavy rifle fire, remained with him from 4.30 p.m. until dark, when stretcher-bearers came up and carried him back to the Battalion Headquarters. He died at Poperinghe the next day.

* Of Vancouver; later A.D.C. to Major-General (now Lieutenant-General Sir) A. W. Currie, Major and Croix de Guerre; now D.A.D.M.S. Canadian Army Corps. Good blood tells : Captain Gibson is the son of a most distinguished and versatile Edinburgh physician, the late Dr. G. A. Gibson. 


\section{THE SECOND BATTLE OF YPRES}

On the evening of the 23 rd the Germans continued to turn their attention to the right half of the front, subjecting the trenches of the and Brigade to heavy shelling. Here, as giving a vivid account of conditions at the front, I cannot do better than quote the description of Captain W. M. Hart, ${ }^{*}$ M.O. of the 5 th Battalion.

"During the next two days-the 2oth and 2Ist -we succeeded in getting the Aid Post pretty well cleaned out, and the worst of the shell holes filled in with sand bags. The central room, which had a large fireplace, I took as a dressing-room. By means of empty sand bags we closely covered the windows and doors, and so were able by means of candles to have the room well lighted up without disclosing our position to the enemy, except for aeroplanes and observation balloons. We were also able to have a fire in the fireplace during the night, when smoke could not be seen, which proved very comforting, not only to the wounded while being dressed and waiting for the ambulance, but also to ourselves, as the nights were still quite cold. . . .

" On the night of the 23rd the enemy commenced to shell our part of the line very heavily with shrapnel and high explosives, in addition to rifle and machine-gun fire, which shelling was destined to continue almost without intermission, and at times reaching a terrific volume, until the 27 th. During the night of the 23rd I had some of the worst cases of shell wounds with which I had to deal, one man being wounded in eleven places. From his

* Now Major (acting Lieutenant-Colonel), M.C. ; late Officer in Charge of Chatham House Annexe, Ramsgate; at present O.C. Canadian Special Hospital, Lenham. Mentioned in Dispatches, January 18th, 1916. 


\section{WAR STORY OF THE C.A.M.C.}

foot I removed a large piece of high explosive casing, which pierced it, projecting both sides, and this was perhaps the least grave of all his wounds, some being of huge extent, and rendering the dressing of them under the difficulties existing no easy matter.

"As the stream of wounded began to increase and stretcher-bearers became in great and greater demand, we took the only remaining door of the house off its hinges, and, as it was thick and heavy, it did excellent duty as a dressing-table, supported on four boxes. During the next two days and nights, the 24th and 25th, the floor of the room, as well as those of the five smaller rooms around it, a small cellar, the loft above it, and a dug-out outside the building, were almost continuously covered with wounded men and officers from my own and half a dozen other Canadian and English units, in spite of the fact that all the wounded able to walk at all, after being dressed, were continually being sent back along the road to Wieltje, as after the night of the 23rd no ambulance succeeded in reaching my dressing-post." From the evening of the 23rd to the morning of the $26 \mathrm{th}$, approximately sixty hours, Captain Hart was scarce ever off his feet, eventually losing track of time, as night and day " brought no change in or respite from the stream of wounded, limping, crawling, or being carried to the Aid Post." 


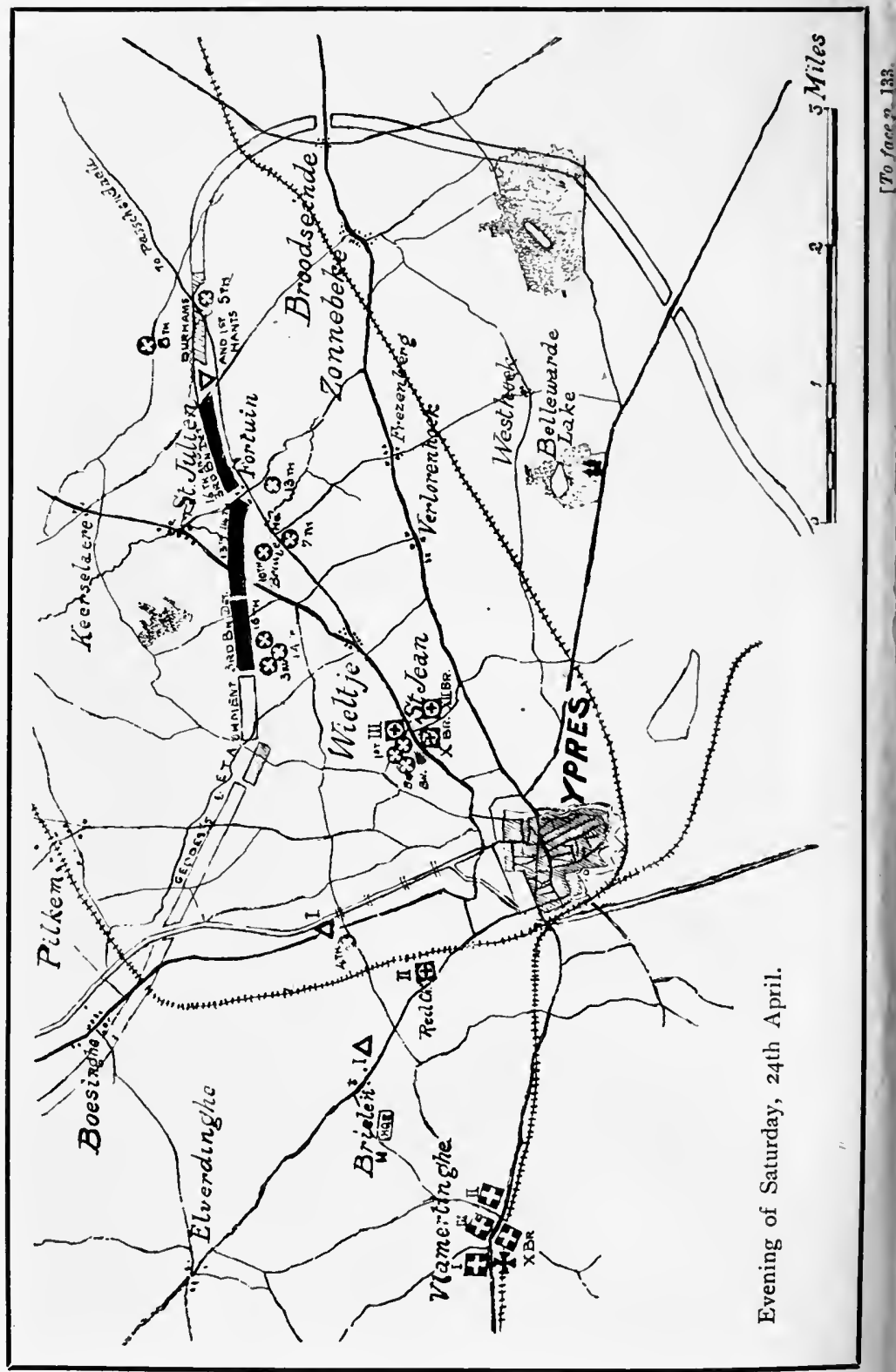




\section{CHAPTER VII.}

THE SECOND BATTLE OF YPRES (continued)

SATURDAY AND SUNDAY

From such an account of one of the Regimental Aid Posts as that given at the end of the last chapter the condition at the Main Dressing Stations can be imagined. During the course of Saturday, the 24th, at No. 3 Field Ambulance, not only the men's billets, but now the Mairie opposite, were also filled with wounded. There was "tremendous congestion." Like conditions prevailed at both the other M.D.S.'s, and the Red Château at Brielen.

A glance at the map will show how close to Brielen were the German lines at this juncture. On Saturday forenoon, bringing up their guns, they shelled the little village with increasing intensity until the and Field Ambulance in the School-house had to make a hurried departure, the ambulances of the 3 rd coming to their assistance, helping to remove patients and equipment to Vlamertinghe. It looked as though the Canadian lines might at any time be driven in, and as though Captain Stone, with the bearers of the Ist Field Ambulance, operating on the other side of the canal, would be cut off. Under the heavy shell fire it did not appear possible to get the wounded 


\section{WAR STORY OF THE C.A.M.C.}

over the Canal to the Brielen Dressing Stations. Nevertheless, a messenger came through from the Captain with the cheery report that he was all right and would hang on till dark, when he hoped to get the wounded out, at which time he asked that transports should be rushed to the Canal.*

Fortunately the advance of the Germans in the northern area was arrested, and, as a matter of fact, when the M.D.S. evacuated the School-house at Brielen, Captain Stone marched some of his bearers over the Canal and took possession, placing a corporal in charge to direct the walking wounded, and a cook to prepare food for his bearer section. Having done this, he returned to the Collecting Post at the farm beyond the Pilkem road. In the evening after dark he evacuated this, carrying back some twenty wounded to the School-house; one of the wounded, he recalls, was conveyed in a wheelbarrow. Next he reopened the Collecting Post on this side of the Canal, and the night of SaturdaySunday was spent clearing to this from the farm beyond the Pilkem road. Despite the fact that the Canal and the roads were being heavily shelled, he did not lose a single one of his bearers : indeed, only one of the hundred or so under him was wounded.

Lieutenant-Colonel Raikes, then M.O. of the $4^{\text {th, }}$ affords a confirmatory account. When the German artillery attack was at its highest this Saturday morning, he was shelled out of his shed by the estaminet on the Canal Road, and retreated over the railway, where he came across a French Aid Post outside Brielen. He was still under shell fire, but, finding a fairly solid brick house to the

* From the private diary of Lieutenant-Colonel (now Colonel) Chisholm, D.S.O., then D.A.D.M.S. Canadian Division. 


\section{THE SECOND BATTLE OF YPRES}

south of this, he converted it into a R.A.P., collecting the wounded here throughout the day. At dusk he returned and occupied the estaminet which had been vacated by the rst Battalion Headquarters Staff. And here he stayed throughout a very busy night. There was no one to evacuate for him, so that the building became " chock full" with some I20 cases, laid in rows upon the floors of the different rooms. $\mathrm{He}$ and all his bearers were by now dead tired. A bearer had but to sit down to fall straightway into a heavy sleep. Happily, wounded men helped each other along to the Aid Post, and so helped to lessen the strain upon his staff of bearers.

By now the very stress of work had taught them all methods of organized labour-saving and economy of effort. Thus, to guard against the back-aching labour of bending over each stretcher case, his bearers devised for him high trestles, upon which the stretcher was placed as each wounded patient in turn had the first aid dressing removed. Several bearers were detailed to form an operating room staff, certain to move the patients, one to remove the dressings, another to superintend the stock of dressings and deliver those needed for each particular case, he himself superintended the treatment of each wound and gave injections of morphine.*

* This, by a very simple and expeditious method: Two bottles, containing the one absolute alcohol, the other a solution of morphine, were each closed by a rubber membrane fastened securely round the neck. The hypodermic needle was sterilized by plunging it through the membrane into the alcohol. For use it was withdrawn, attached to the syringe, and now the required dose obtained by plunging through the rubber into the morphia solution. When the injection had been given, the needle was forthwith plunged through the rubber into the alcohol. 


\section{WAR STORY OF THE C.A.M.C.}

What he will never forget was the quiet that reigned through the crowded estaminet all through that night. No sooner had the wounded man been given his injection, and dressed, and given a cup of hot beef tea, than he went to sleep, and slept like a child. There was no sound save of regular breathing. Among them were a few Turcos who had been out on the field wounded for two days, i.e., since Thursday evening. Their wounds were already putrid and foul-smelling.

Early on Sunday morning some horse ambulances came along and began the removal of his wounded. At ten o'clock he went into Vlamertinghe with one of these, and secured from Colonel Ross, of No. I Field Ambulance, some motor ambulances. $\mathrm{He}$ describes the Colonel as working away like a Trojan, with no tunic and no belt, but attired in an old green sweater-and getting things done.

For a description of conditions at the front that Saturday, further to the right between Wieltje and St. Julien, I am indebted to Captain (now Major) Greer, of the and Battalion. It will be remembered that his R.A.P. was well forward, and that he was busy all Friday and Saturday morning (p. I29). At about three o'clock on Saturday afternoon, orders came for this unit to fall back to what was known as the G.H.Q. line, about 3 rd Brigade Headquarters, which from now onwards came to be in the immediate neighbourhood of, if not actually in, the front line. At the time of the retirement (which necessitated the evacuation of his R.A.P.), he writes: "I had fourteen stretchers (cases) and twenty-two walking cases which had to be cleared. Luckily I had sufficient stretchers and used batmen, etc., to complete the stretcher squads. 


\section{THE SECOND BATTLE OF YPRES}

The route back was well sprayed with machine-gun bullets and shells, but these cases were successfully cleared by my bearers. One of the walking wounded was hit on the thigh and became a stretcher case, and one bearer was hit on the leg on this trip. These cases had to be carried to the Asylum at Ypres, a distance of four miles, approximately, and that by men who had worked continuously for over forty-eight hours, a remarkable feat in my opinion. I went part of the way back with them, dressing the two cases, and my sergeant conducted them the rest of the way. His work and that of all my stretcher-bearers throughout the whole engagement was beyond praise. Later, Sergeant Russell was awarded the Military Medal.

"I retired to the 3 rd Canadian Brigade Headquarters Dressing Station, where Captains Haywood, Glidden and Scrimger were working, and we worked there till about midnight, when I found the remnants of my battalion, who were then in support in front of St. Jean."

By 6 p.m. on Saturday evening, the M.D.S. of the and Field Ambulance was at work in a schoolhouse at Vlamertinghe near to the station. When, next morning, C Section, under Major Snell from the Red Château, joined it, the complete establishment of all three sections was under one roof. The Red Château had by this become an Advanced Dressing Station of the 2nd. On Saturday evening shelling rendered the estaminet at St. Jean untenable, wherefore Captain Burgess moved his men to this point.

From this time onward, as indicated by the map, Vlamertinghe became the one medical centre of the Canadian area. Yet other units were brought 


\section{WAR STORY OF THE C.A.M.C.}

in, and, indeed, came as a great relief, for by now the heavy strain upon the Canadian Field Ambulances was beginning to tell. From O.C. down to ambulance driver, every member of each unit had been working desperately and doggedly without intermission. "Not a soul," says Colonel Chisholm in his notes for this afternoon, "has had any sleep since the action began." The stretcherbearers, in particular, both Regimental and Field Ambulance, with the long and strenuous carries, were becoming worn out. During the course of the $24^{\text {th }}$, the Bearer division of No. ro R.A.M.C. Field Ambulance (O.C. Major F. B. Wingate, R.A.M.C.), belonging to the 4th Imperial Division, came to their aid : its Tent subdivision opened up an A.D.S. at St. Jean, and early on the forenoon of Sunday, the $25^{\text {th }}$, it opened its M.D.S. in Vlamertinghe church hall and church. So, too, on the 24th, the Bearer division of the $\mathrm{x} 2 \mathrm{th}$ British Field Ambulance, under Captain H. Steward, R.A.M.C., Lieutenant A. C. Jebb, S.R., and Lieutenant Paine, were placed under the A.D.M.S. Canadians, and they likewise established an A.D.S. at St. Jean. This unit, it may be added, lost two of its motor ambulances by shell fire.*

Later, when on the 26 th the Indian Division came into action on what had been our right, the 8th Indian Field Ambulance came from Ouderdom and opened its M.D.S. in a school near the Vlamertinghe church, sending its bearer division to St. Jean.

* I am indebted for these details regarding Imperial units to Major F. S. Brcreton, of the War Office, in charge of the medical records of the British Army, who most kindly placed his material regarding the Second Battle of Ypres at my disposal. 


\section{THE SECOND BATTLE OF YPRES}

All through Saturday heavy fighting continued: the wounded poured into Vlamertinghe in every sort of vehicle, and all divisions of the Field Ambulances worked smoothly and effectively. With nightfall, the Dressing Stations began to receive the wounded who had accumulated during the day between the Canal and St. Jean, as again from north of St. Jean, where the Ioth Indian Division had been in action.

Close upon midnight came a message to Headquarters that a Battalion passing through the main square of Ypres (in front of the Cloth Hall) had been heavily shelled, with many casualties. Although he had but just come in from the front after forty-eight hours' hard work without rest, Major J. L. Duval, of the Ist Field Ambulance, volunteered to take cars and bearers into the city, which could be seen from Vlamertinghe to be aflame everywhere and burning vigorously. For the good work he accomplished upon this and the following night, this officer received mention in Dispatches.

The shelling at St. Jean, which had been severe enough during the evening to cause the evacuation of the A.D.S of the 2nd, continued all through this night, so much so that early on Sunday morning the A.D.S of the $3^{\text {rd }}$ Field Ambulance had been destroyed, Major Templeton and the personnel only leaving it when it was burning to the ground. One motor ambulance had been " knocked out." It was impossible to collect wounded during the daytime, so they returned to Vlamertinghe. But at seven in the evening of Sunday, they were back establishing their fourth A.D.S., this time again at Wieltje, where all through the night they worked under heavy shell fire. 
The A.D.M.S., Colonel Foster, spent the night of Saturday and Sunday at the front superintending the evacuation of the wounded. At midnight he telephoned that all was proceeding smoothly, the convoys to St. Jean working steadily and without a break. Despite the difficulty of getting ambulances up, the front had been evacuated by 3.30 a.m., all save some hundred cases beyond Fortuin, where several great elms, which had formed a grove on this side of the village, had been brought down by shell fire and completely blocked the road. A little distance beyond this point Captain Hart, of the 5th Canadian Battalion, had collected some forty-five severely wounded and placed them in the cellar of a farmhouse. Some three-quarters of a mile further on was Captain Hart's R.A.P., and here he had fifty cases which could not walk. It was now exposed, as is indicated by the map. Already that night ambulances had endeavoured to reach him, but had encountered the fallen trees. In the early hours of the morning two cars were sent specially from Vlamertinghe with intent that they should pick up engineers at Brigade Headquarters, and take them to remove the obstruction. Unfortunately, a misdirection or misunderstanding led to a painful double disaster, namely, the cars and their occupants fell into the hands of the enemy, as did, later, the occupants of the R.A.P. which they should have relieved. I cannot do better than quote the account given to me by Private (now Sergeant) A. W. Walsh, of the 3rd Field Ambulance. "At about 2 a.m., April 25th, I9I5, two motor ambulances left our Hospital at Vlamertinghe with orders to proceed to 3 rd Brigade Headquarters, located in a farm- 


\section{THE SECOND BATTLE OF YPRES}

house about one mile south-west of St. Julien. Upon reporting at Headquarters, we were told by an officer, whom I did not know personally, to go on to the I3th Battalion Aid Post at St. Julien and bring out as many wounded as possible. I have since learned that this Aid Post was moved the previous evening. A tree had been reported as having fallen across the road. Two infantry men were sent from Headquarters with us to help remove the obstruction, which our car ran into about a quarter of a mile from St. Julien.

"When the ambulance stopped, two or three of us jumped off. Over on our left two star shells shot up, and immediately a fusillade of bullets riddled our cars. Driver Fox, standing in front of the foremost, was instantly killed. Driver Stevens was shot dead sitting in his seat. Private Nelson received a bullet wound in the head. Private Carr was shot in the thigh. One of the infantry men fell apparently very badly wounded. The second infantry man I did not see after the cars stopped.

"Driver Pickles and I were uninjured, and attempted to turn one of the cars round. A German patrol party appeared out of the darkness and took Private Carr, Driver Pickles and myself prisoners." Only one of the seven men with the two cars-Private Nelson-escaped, and he, when hit, falling off the car as though dead, managed to creep into the roadside ditch and, escaping detection, worked his way back to our lines.*

* Walsh, Carr and Pickles were sent to the prison camp at Giessen. The two former, instead of being freed immediately, remained there eight months, until December 24th, 1915, and then, after detention on the Dutch border for a fortnight, reached England on January 7 th, 19I6. Unfortunately, while 


\section{WAR STORY OF THE C.A.M.C.}

The explanation of this most regrettable misdirection that seems most probable is either that the leading car-driver went by mistake to the Headquarters of the 3 rd instead of the and Brigade, or that both roads, that to St. Julien and that beyond Fortuin, happened to be blocked by fallen trees, and understanding that men had to be supplied to remove an obstruction, the Staff Officer of the 3rd Brigade, being more familiar with conditions in his own area, immediately jumped to the conclusion that the St. Julien obstruction had to be removed, and so directed the cars to proceed to the St. Julien Aid Post without a thought that this had been evacuated twenty-four hours before. This explanation, however, does not absolve the officer for sending the cars into the German lines.

Colonel Foster himself endeavoured to reach the R.A.P. of the 5 th, having visited all the other Aid Posts during the course of the night. He reached the farmhouse just beyond the obstruction, and records in his diary: "I inspected one group of these men, forty-five cases in the farmhouse, and found that their wounds had all been dressed and they were fairly comfortable in a cellar. I detailed Captain Musson, C.A.M.S. (2nd Field Ambulance), with extra dressings and two orderlies, to remain with the wounded until they could be moved the following night under cover of darkness to the Dressing Station. It was reported that fifty cases three-

Driver Pickles had been attached to the 3 rd Field Ambulance since February, and had been definitely transferred from the Motor Transport (Imperial A.S.C.) to the C.A.M.C. a few days before his capture, the change had not been noted in his paybook, nor had he been given a new identity disc. Although representations to this effect have been made to Germany, he still remains a prisoner. 


\section{THE SECOND BATTLE OF -YPRES}

quarters of a mile further on, in charge of Captain Hart, C.A.M.C., were similarly situated. As time would not permit of my proceeding to this latter place before daylight, at which time the road was under fire of the enemy, I gave full instructions to Captain Musson to communicate with Captain Hart that I would arrange for the clearing of the road, and would send sufficient cars to remove all cases that night so soon as darkness would permit."

The condition of these officers and their wounded was parlous. Two or three times during the course of the morning and early evening of Sunday the 25th messages were sent urging the evacuation of every case that could possibly be moved, as retirement of the battalion might be necessary at any moment. As a matter of fact, Captain Musson and all his wounded were retrieved on Sunday night by ambulance cars under direction of Major Chisholm, D.A.D.M.S. Captain Hart and his party were not so fortunate. We shall have to follow their fate later.

But they were not the only Aid Posts that at this period of the engagement were in difficulties. That for the 3rd and I4th Battalions, with Captains Haywood* and Scrimger as Medical Officers, had been established in one of the moated farmhouses which are a feature of this part of Flanders, the farm being at the same time the Headquarters of the 3 rd Brigade, under Colonel R. E. W. Turner. We possess Captain Scrimger's record of the doings at this point, and it gives a vivid picture of the happenings at this part of the line. Captain

* Captain (now Major) A. K. Haywood, M.C., returned to Canada in 1916. 


\section{WAR STORY OF THE C.A.M.C.}

F. A. C. Scrimger* is one of the noteworthy figures of the Second Battle of Ypres. The son of a distinguished minister who for long years had been Principal of the Presbyterian College in affiliation. with McGill University, Montreal, he himself before the war had done good work as assistant surgeon at the Royal Victoria Hospital, and was demonstrator in surgery in the McGill Medical School. He came over with the First Contingent as Medical Officer with the I4th Battalion (the Royal Scots of Montreal, or Royal Montreal Regiment). To his great distress an attack of bronchopneumonia prevented him from crossing overseas to France with his regiment, another being appointed in his place. By quiet persistence he managed -as late as April I5th-to cross to France and become attached to the 2nd Field Ambulance, and the beginning of the fight saw him in charge of the A.D.S. of the 2nd Field Ambulance at Wieltje. It was only the day after the action had begun -at four o'clock on the afternoon of the 23rdthat the welcome instructions reached him to report to the 3 rd Brigade for duty with his old regiment, the I4th Battalion. He had been trying to get back for weeks, and had been with it little more than a day when he did that which brought him the V.C. I cannot do better than give his own words: $\dagger$

"April 24th. We have only six stretchers, two having been lost or broken. It is impossible to get the wounded in. A good deal of ground has been lost, and for the wounded in this area nothing can be done. Am now forty-eight hours without sleep. I don't feel it. There is a pretty vigorous

* Captain Scrimger, V.C., is now Chief Surgeon of No. 3 C.G.H.

†From a "letter diary" written for transmission to his family. 


\section{THE SECOND BATTLE OF YPRES}

shell and rifle fire through the gaps. They. got five men through one gap. Our supplies are none too abundant. Very few wounded can get in, the fire is too hot. I spent the afternoon and up to the present at night in the G.H.Q. lines. It is safe enough except when I have to go along the trench, dressing. I got rapped on the heel by a shrapnel this afternoon, and thought my time had come several times; but was able to dress a number of cases - too many. One a wound through the brachial plexus; during the dressing, shrapnel landed three times in the lee parapet.

"April 25th. This has been a big day. I write in a sort of dug-out while we wait for orders. I got an hour's sleep this afternoon, the first for three days and nights. The fire slackened in the trenches so that men could get out. I returned to the old dressing station at Brigade Headquarters. There was a heavy shelling all morning. We decided that it was no longer tenable. Since my battalion was holding that line and there were thirty or forty of my men and others wounded, I offered to stay. The others moved out. The shell fire grew more and more severe. I decided to send out walking all cases that could walk. Previous to this a stretcher-bearer party had been sent towards St. Jean. It was promptly followed by shrapnel, and, we fear, lost. All wounded who could not walk were collected in what appeared to be the strongest and safest room. About this time, lack of sleep and food, anxiety and the excitement of a vigorous cannonade, had worked me up to such an extent that I did not care what happened. I caught myself once out in the open cursing the Germans and all their works. I first now felt a 


\section{WAR STORY OF THE C.A.M.C.}

personal hatred towards them. I was afraid, too, to speak for fear of breaking down."

But it was at this stage that Captain Scrimger did what won for him the most coveted of all military if not of all worldly honours, and rather than give his own modest account of the occurrence it will be well to combine his own description with the official record attached to the announcement of the award of the Victoria Cross, ${ }^{*}$ and the account given by the officer whom he saved. $\dagger$

About 5 p.m. there was a sudden fierce outburst of shelling, evidently directed upon the Staff quarters at the other end of the farm. Captain E. F. McDonald, Staff Captain of the 3rd Infantry Brigade, was standing in front of the building when he was hit in the face, neck and shoulder. He was promptly dragged into the farm building, where Captain Scrimger dressed his wound. His condition was so grave that he was regarded as "done for."

Up to this point the stable which served as an A.D.S. had not been seriously hit, but now the farm building proper took fire, and as there was a fair store of ammunition in it, Colonel Turner ordered its immediate evacuation. The entrance across the moat was on the exposed side, wherefore all had to jump into the water and swim to safety. $f$ Captain Scrimger carried Captain McDonald out, and when he reached the moat used its bank as a trench. Laying him in this shelter, he coiled

* See the Times, June 24th, I9r 5.

$\dagger$ The Canadian Gazette, July 22nd, I915.

‡ Apparently it is this uncomfortable arrangement which has caused this farm to figure in later history as "Shell Trap Farm" and "Mouse Trap Farm." 


\section{THE SECOND BATTLE OF YPRES}

his body around the wounded officer's head and shoulder to protect him. They were half buried in mud and more than half wallowing in water, and there the two lay while "whizz bangs"high explosive shells-poured into the farm. Over and above this some 200,000 rounds of rifle ammunition caught fire and added their noise to that of the shelling. Five shells fell within a radius of fifteen feet of them. By good luck neither was hit ; fortunately, also, the stable, the R.A.P., had not been set on fire; in it were some twenty seriously wounded who could not be moved in the precipitate evacuation of the other buildings. At length, when the fire slackened, Captain Scrimger gathered a volunteer stretcher squad, which carried Captain McDonald and the score or so other patients to an ambulance which was collecting wounded in the centre of Wieltje, itself no very healthy resort since, as Captain Scrimger reports, here too a fresh shell dropped every five minutes and the place stank with lyddite fumes. It is proper to add the final sentence of the official Victoria Cross record : "During the very heavy fighting between April 22nd and 25th Captain Scrimger displayed continuously day and night the greatest devotion to his duty among the wounded at the front."

To the rest of the C.A.M.C. no award could have given greater pleasure than this to Captain Scrimger -of whom it may truly be said in Canadian phraseology that in matters concerning himself he had ever shown himself wholly devoid of either "push" or "pull," concerned only in doing his duty as an officer and a medical man, and that quietly and conscientiously. While others, it may be, have accomplished deeds of equal bravery and 


\section{WAR STORY OF THE C.A.M.C.}

devotion which have been passed by without recognition, none can grudge, but on the contrary all must rejoice, that recognition came to him. Bene meruit !

For his fine work in the evacuation of the wounded from the burning farm Captain A. K. Haywood, M.O. of the 3 rd Battalion, was awarded the Military Cross. The Headquarters of the 3 rd Brigade and the R.A.P. of the 3 rd Battalion, with H.Q. of the same were moved back to some old French gun emplacements some half-mile further back, between Mouse Trap Farm and Wieltje.

There was at this stage, in fact, nothing for the Canadians but to retire. As Captain Hart expresses it : "The enemy's aeroplanes were continually circling over us and flying low up and down the line of our trenches, while at one time I counted four German observation balloons anchored at the corners of a large square, of which we apparently formed the centre. It was noticeable to all of us that in spite of the terrific shelling we were receiving at the hands of the Germans from all sides of the salient, either our artillery were failing to make any effective reply, or had been withdrawn." We now know that at this stage of the campaign we were woefully deficient both in ammunition and in aeroplanes.* It is only thanks to the stout

* One Medical Officer of the 2nd Brigade, writing of this period, says : "An S.O.S. call was sent to the battery supporting us, and we hoped to see the 'curtain of fire,' as it was at that time called. Only a single round every minute or two was the result. It was one of the most disappointing and depressing sounds that we had ever heard. Our one feeble minute field gun, while the enemy batteries were in salvos with everything up to 5.95 in. I If the contrast had not been so serious, it iwould have been extremely humorons, so great was the contrast. It sounded like a pea-shooter in a foundry." 


\section{THE SECOND BATTLE OF YPRES}

hearts of our men and the superb rifle fire of our infantry that Ypres was not taken and the Canadian First Division wholly annihilated.

The complete obliteration of the trenches under the German shell fire, and the danger of being left in a dangerous salient, brought it about that fighting doggedly along the whole of the front, the and Brigade also, with the Durhams and Hampshires in support, fell back to a line stretching from Fortuin towards Passchendaele.

Again on the night of that Sunday the Main Dressing Stations under the control of the A.D.M.S. First Canadian Division were filled to overflowing. In the twenty-four hours ending at six on the morning of the 26th, thirty-five officers and $x, 694$ of other ranks had passed through the Main Dressing Stations under the control of the A.D.M.S. First Canadian Division. The increasing support being given by the Imperial troops is shown by the fact that of these casualties I,35I were Imperial, 36I Canadian. On Saturday afternoon two British Brigades, the roth and the Northumberland, passing through the Canadian troops, had undertaken the offensive, and despite heavy losses arrested the further progress of the Germans. With this the 3rd Brigade fell back to the reserve trenches. That same evening the Durhams and Hampshires had come up to the support of the and Brigade.

With the retirement of the and Brigade on the Sunday occurred the last of the heavy Canadian casualties in the battle. The Brigade had broken the German onrush through sheer force of manpower : it had held its line unbroken for three whole days, save when on the 23rd the 8th Battalion (goth Winnipeg Rifles) had been gassed and momen- 


\section{WAR STORY OF THE C.A.M.C.}

tarily lost its trenches, to retake them under the gallant leadership of Lieutenant-Colonel Lipsett.

That evening, after the retirement, both Canadian Brigades were relieved and sent into reserve trenches, although, when on Monday the 26th the Germans again pressed forward, our men of the and Brigade, worn out and reduced to one quarter the original strength, marched with stout hearts once again into the fray. 


\section{CHAPTER VIII}

THE SECOND BATTLE OF YPRES (concluded)

BUT, if war-worn and weary the two Canadian Brigades were brought back to reserve, the medical units for several days to come, until the 3othnay, more, were busied to their full limit. Working heroically, it was now that they suffered their heaviest.

In our description of Sunday's fighting we had left Captain Hart with his fifty seriously wounded cases in the R.A.P. of the 5th Battalion. Each message that came from the adjutant during the course of Sunday was followed by the evacuation of every man able to move, who, one supporting the other, made their way under shell fire towards Ypres. But several wounded officers of the $5^{\text {th }}$ were left-Major Sandeman, who was hopelessly mutilated by shrapnel, Captain Allen, with an abdominal wound and paralysis of the right leg, Lieut. Fitzpatrick, with bad shell wound of the head, and later on in the day the adjutant of the

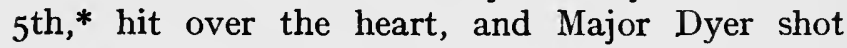
through the lungs. When news was received of the actual retirement of the battalion to take up a position near the bombarded cross-roads, it

* Then Major, now Brigadier-General F. Hilliam of the British Army, to which he was subsequently seconded. 


\section{WAR STORY OF THE C.A.M.C.}

was clear that the Aid Post would be well beyond our lines, between our fire and that of the enemy. Major Edgar, of the 5th, afforded what men he could spare, and these, with Captain Hart's stretcherbearers, reduced the number left to about eighteen. Captain Hart gave his horse to a wounded officer of the 8th, Major Dyer was removed on the stretcher on which he had arrived, Captain Allen on another, Lieut. Llewellyn, of the Monmouths, badly wounded in the leg, gallantly gave up his stretcher to the adjutant of the $5^{\text {th, }}$ offering to get away with the assistance of his batman and one of our men.

The night was passed waiting for ambulances which never came. Although by now the R.A.P. was situated in "No Man's Land," there was still hope, both on the part of the medical headquarters staff and of the M.O. in charge that the occupants would be retrieved. Lieutenant-Colonel Chisholm, D.A.D.M.S. Canadians, proceeded at seven on Sunday evening, with no less than twenty-one ambulance cars, to take charge of all stretcher cases at Wieltje. At St. Jean on the way up they were badly shelled, losing two cars. Taking ten cars with him he succeeded in clearing the Aid Post in the farmhouse near the cross-roads, where it will be remembered the A.D.M.S. on the previous night had left Captain Mussen in charge. The forty stretcher cases here were safely removed. But the obstruction still remained, and he could not on this journey reach Captain Hart's Aid Post further on.

But the above was far from being the only disaster to the Ambulance Service that Sunday night. When the D.A.D.M.S. returned to and 


\section{THE SECOND BATTLE OF YPRES}

Brigade Headquarters at Wieltje at two o'clock he found that the wounded in that immediate neighbourhood had all been collected; he returned, therefore, to St. Jean to supervise the evacuation of wounded there. Not only the Canadian and attached roth British Field Ambulance cars, but those of the 27th (Indian) Division, were converging upon the village, which, with the falling back of the original line, had by now become the Dressing Station for the whole northern half of the salient, not to say its Regimental Aid Post. He found no less than ten Regimental Medical Officers established in the village. Forthwith he proceeded to straighten out the situation, sending several R.M.O.'s to establish Aid Posts a mile nearer to Ypres, and with them sending all the walking cases. The motor ambulances he got under way with about one hundred stretcher cases collected out of the cellars in the village, and finally he arranged that until sunrise six Canadian cars, under Captain P. G. Brown (2nd Field Ambulance), should continue clearing back from Wieltje to St. Jean, the road after dawn being reached by rifle fire; Captain A. S. Donaldson* (3rd Field Ambulance) was placed in charge of the ambulances evacuating back to Vlamertinghe, and Captain Greer, M.O. 2nd Canadian Battalion, left in charge of the Dressing Station at St. Jean.

Just as the situation seemed clear, there occurred a heavy casualty. A motor ambulance convoy was standing on the main road opposite the A.D.S. when a heavy calibre shell fell upon the centre of the road close to a car filled with wounded. It

* Now Lieutenant-Colonel, D.S.O.; O.C. No. 3 Canadian Field Ambulance. Twice mentioned in Dispatches. 


\section{WAR STORY OF THE C.A.M.C.}

wrecked the car, killing sixteen men and wounding twenty. Among these, both seriously wounded, were Major J. L. Duval and Captain R. H. McGibbon, of No. I Canadian Field Ambulance.* A second shell tore away the end of the dressing station, wounding Captain Barrie, R.A.M.C., completing the wreck of the ambulance car and setting it on fire.

Nor did that end Lieutenant-Colonel Chisholm's experiences. Returning to Vlamertinghe just before dawn, his motor-car, which had been hit at St. Jean, "stalled" and came to a standstill at the greatest danger spot on the whole road, namely, at "The Devil's Corner" in Ypres-a spot that since the beginning of the battle had been subjected to continuous shell fire. By great good fortune just then a Red Cross car, bearing the device, "From Friends in Boston," appeared round the corner, and the wounded were transferred to this godsend without mishap. As the D.A.D.M.S. remarks: "That car was the most welcome sight I ever saw. The spot was, indeed, a bit of hell."

Yet one more escape came to him. Arrived at Vlamertinghe, although he had not been in bed since the 22nd, and might well, after his severe night's work, have given himself a thorough rest for some few hours, he did not seek his billet in a cottage, but, instead, slept for two hours upon the office floor at medical headquarters. He had been there about an hour when a large calibre shell dropped into the billet allotted to him, wrecking the house clean through to the cellar! No wonder

* Major Duval died of his wounds three months later. He had received his majority the week preceding the battle. 


\section{THE SECOND BATTLE OF YPRES}

that later, on Monday, he records: "All nerves on edge to-day like one huge toothache."*

Let us return now to the fate of Captain Hart and the wounded at the 5 th Battalion R.A.P.

The night, to repeat, was passed waiting for ambulances which never came. Towards dawn, at about three-thirty, as there was nothing to be done for the wounded, and no Germans could be heard or seen in the immediate neighbourhood, Captain Hart started off with the one orderly he had allowed to stay with him-in private life a close personal friend-to report at Brigade Headquarters, taking with them a bomb-thrower of the 5th, shot through the abdomen, and two other badly wounded men who could just drag themselves along. These they placed in a bomb-proof cellar at the bombarded cross-roads, and then went through what had been the village of Wieltje, now nothing but a heap of ruins with no roofs and but few walls still standing. Dead men and horses were in evidence all along the road. At St. Jean Captain J. M. Glidden, C.A.M.C., $\dagger$ took them to a cellar, to get something to eat and to sleep while he carried the message to headquarters. Captain Hart records how he "fell on sleep" and off his chair three times while eating breakfast, and then, without removing eyeglasses or spurs, slept heavily on a mattress until the late afternoon. At night he went forward with the ambulances. But again fallen trees made it impossible to reach the Aid Post.

* I quote the happenings of this night from Colonel Chisholm's private diary.

† Wounded a few days later by a bomb dropped from an aeroplane, when standing by a dug-out Aid Post near the Canal bank. He died in a hospital at the base. 


\section{WAR STORY OF THE C.A.M.C.}

What with making arrangements to have the obstacle removed and the ambulances sent early the following night, it was broad daylight on Tuesday morning before he found himself on the way to the Aid Post, taking advantage of every ditch and scrap of available cover. The road was too open and near the cross-roads, he was captured by a squad of Germans who rose up on either side. His experiences as a prisoner form another story.

Throughout Monday and Tuesday the field ambulances were as busy as if not busier than ever. Yet another came under the control of the A.D.M.S. Canadian Division, when on Monday the Lahore Division came into this area and into action, and the 8th British Field Ambulance, under Major R. E. Powell, R.A.M.C., attached to it, established a Main Dressing Station in a school on the Ypres road near the railway station. The A.D.M.S. by now had six field ambulance units in the area under his charge.

Reading the various independent accounts afforded in the war diaries, it is not a little interesting to observe how, despite the long continuance of the strain, each day saw the medical organization settling more completely into place, such defects as there were being rapidly remedied. This is well exemplified by the admission records of the Main Dressing Stations. Admissions reached their highest $(\mathrm{r}, 864)$ in the twenty-four hours up to 6 a.m. on Tuesday, the $27^{\text {th, }}$ only beginning to fall seriously (to 838 ) in the returns of the morning of Thursday, the 29th. But whereas on the 23rd, after the gas attack and sudden opening of the battle, we read of wounded still uncollected, from the $24^{\text {th }}$ 


\section{THE SECOND BATTLE OF YPRES}

onwards the front is reported cleared by dawn, and whereas at first the evacuation from the Main Dressing Stations could not keep up with the admission, the condition steadily improves, until on the 26th all the M.D.S.'s are reported cleared (of cases that can be moved) by to a.m., and on the 28 th at 8 a.m.

It must be admitted, however, that there was urgent cause for this rapid evacuation on the $28 \mathrm{th}$. As the Germans, in their advance, brought their heavy guns forward, Vlamertinghe came within easy range, and at five in the evening of the 27 th the village began to be shelled hotly with shrapnel and sixty-pounders. There were several deaths among the civilians, while a few soldiers were also killed; but none of the patients and none of the C.A.M.C. personnel were wounded. No. I M.D.S. was hit by H.E., and the 2nd Field Ambulance lost three of its horses in the garden immediately behind the hospital. Otherwise the dressing stations were untouched. Motor ambulance convoys were soon brought up, and every vehicle possible was pressed into service to assist in the removal of some 350 lying-down wounded from the dressing stations. For rapid evacuation these were taken to a farm outside the fire zone, which for the next two days was employed as a useful annexe. The office of the A.D.M.S. in the main street was shelled, and it was necessary to remove to a better protected house. His billet also was hit. Arrangements were made with the D.D.M.S. for evacuation by motor ambulance convoys as rapidly as the patients could be brought from the Advanced Dressing Stations. A few shells arrived at 4.30 on the morning of the 29 th, and 


\section{WAR STORY OF THE C.A.M.C.}

again at 9, when the billet of the A.D.M.S., at the curé's house, hit yesterday, was now completely wrecked. At I0.30 a.m. the shelling became more severe, so that Colonel Foster removed his office and staff to the basement of the Mairie, across the road, from the M.D.S.'s of the Ist and 3 rd Field Ambulances. Now the shells came nearer to the dressing stations: While a party of engineers were constructing a shell-proof dug-out in the courtyard of No. 3 M.D.S., one of the party was severely wounded by an exploding shell, and both Lieutenant-Colonel Watt, the O.C., and Captain F. Bell* received slight wounds. Finally, at I a.m. the following night both Nos. I and 3 Main Dressing Stations were shelled out. The house occupied by the Ist Field Ambulance was hit many times; by great good fortune the patients had just been removed, when a big shell burst in what had been the main ward, completely demolishing it. So, too, hardly had the No. 3 M.D.S. at the girls' school been emptied, when a shell came through the roof. The bomb-proof shelter proved of service, as a few orderlies and some of the more severely wounded patients were left there to await convoys and direct other cases that might arrive to the farm to which the unit had retired.

After five days of intense and unremitting fighting, the war-worn Canadian Brigades had been withdrawn from the firing line on Monday, the 26th, and, while they remained in reserve, for certain infantry units this day represented the close of active participation in the battle. Not until the $4^{\text {th }}$ and $5^{\text {th }}$ of May was the division withdrawn out

* Now Lieutenant-Colonel and A.D.M.S in charge of Hos pitalization at Medical Headquarters, London. 


\section{THE SECOND BATTLE OF YPRES}

of the area, and attached to the First Army, under Sir Douglas Haig, with General Alderson's Headquarters at Nieppe. During the intervening eight days other units of the division were busily occupied as occasion required. Thus, on this very Monday, the 26 th, to repeat, the sadly shaken and Brigade, under Lieutenant-Colonel Currie, responded to the call, and manned their old trenches between St. Julien and Passchendaele, and again on Wednesday, the 28th, the 2nd Battalion, under LieutenantColonel Watson, did yeoman service in digging a line of trenches to the left of the British position under heavy fire. Again, on the afternoon of May 2nd, a gas attack upon the greater part of the British front, so serious that it threatened to cause a repetition of the events with which the battle began, led to the Ist Brigade being moved up in support of the Ioth and I2th British Brigades now in the trenches.*

The 2nd Canadian Brigade was still in the trenches when, on the night of the $3^{\text {rd }}$ and $4^{\text {th }}$ of May, Lieutenant-General Alderson, to shorten his line, withdrew his troops to a prepared line running from Westhoek through Frezenburg, to a point some two thousand yards south-east of Pilkem, where it joined the trenches occupied by the French.

The preceding chapters will by their narrative have indicated what must have been the strain upon the administration during all these critical days from Thursday afternoon onwards, days so critical that at most but an hour or two's sleep

* Colonel Foster notes that some two hundred cases suffering from the effects of gas were brought into Nos. Io and 12 Field Ambulances, none of them very severe, 


\section{WAR STORY OF THE C.A.M.C.}

could be snatched here and there. The staff of the A.D.M.S. included but one other officer, the D.A.D.M.S., Major Chisholm; in other words, night and day one of the two, the A.D.M.S. or the D.A.D.M.S., had to be in attendance at the office to receive and act upon messages received from

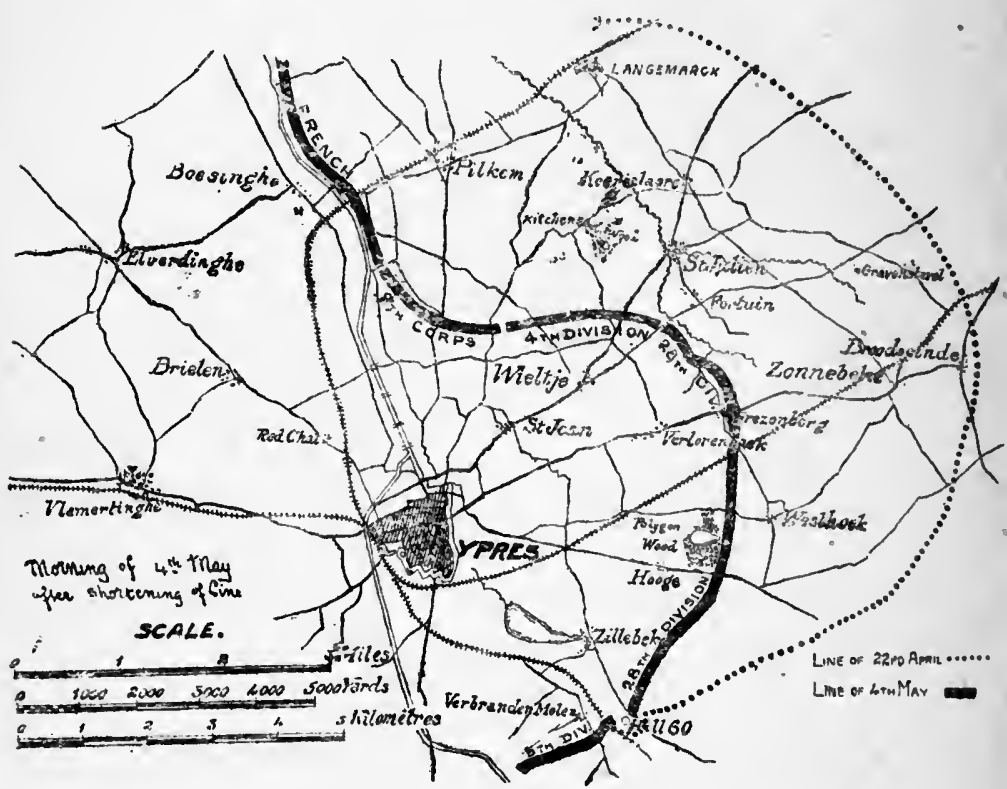

The shortening of the line : position on 22nd April and $4^{\text {th }}$ May.

Headquarters or arriving from one or other section of the front, while the other was in consultation at Headquarters, was supervising arrangements here and there, visiting the Main Dressing Station, or controlling ambulance work nearer to the front. If for the last four days of this period the Canadian troops had been largely withdrawn from the front, and the Canadian ambulance units were no longer 


\section{THE SECOND BATTLE OF YPRES}

active, on the other hand there was the heavy responsibility thrown upon the A.D.M.S. of administering British medical units in an area now largely occupied by British troops, of directing and "making good with" units to : which he was a stranger. Now after ten days of dogged work came the greatest strain of all. That the withdrawal should not be converted into a disastrous rout, it was absolutely essential that it should proceed with clockwork precision and in complete silence during the night hours. The enemy must not know of the movement. With their trenches, as at Broodseinde and Gravenstafel, within ten yards of our line, the difficulties of the situation may be imagined. To quote John Buchan :* "This withdrawal in perfect order, in a very short time and with no losses, was one of the most creditable pieces of Staff work in the war," and (the greater body must here be understood to include the less) "The Royal Army Medical Corps have never done more brilliant work in all their brilliant history." Now the medical arrangements for the larger moiety of the area of withdrawal were carried out by the A.D.M.S. Canadians, acting under the D.M.S. of the Second Army. Upon the A.D.M.S. lay the responsibility of seeing that in this retirement no wounded were left behind in his section to fall into the hands of the enemy. It was the supreme test of his efficiency.

The withdrawal was timed to begin at 8.30 on the evening of Monday, May 3rd. In his full and precise operation orders distributed the previous day, General Alderson had laid down explicitly that east of the canal no movement along the roads

* Nelson's " History of the War," Vol. VII., p. 35. 
in an easterly direction would be permitted between 6 p.m. and 2 a.m. It was essential that the movement of the troops towards Ypres should not be impeded. This, in itself, was a warning to all concerned to see that their wounded were carried back and out of the zone before the evening set in. But there was much else to be undertaken, and too often, and at times unavoidably, the removal of the wounded was put off until the last moment, with the result that through that night the telephone brought frantic appeals to the A.D.M.S. in his office to send forward ambulances, or officers personally besought him to afford help to their units.

It was a trying position. There were the wounded at the front, and at any moment the enemy might discover the movement. It seemed scarce possible that five and a half hours could elapse without their discovering our action. Should they break through, and should the wounded fall into their hands, such is human nature, that he-Colonel Foster-and through him the Canadian Medical Corps, would be held responsible for the loss. This beginning of active service at the front would be the end of his career. And the decision had to be made by a man worn out.

It is to his and to our credit that the soldier was there, and the soldier prevailed. The operation orders were carefully worked out, and to those he must adhere, despite every appeal. No ambulance should proceed eastwards over the canal until the time allotted. But he placed his whole motor and horse ambulance force as close to the line as possible ; instructed them to take a good rest, so as to be thoroughly fit when the time came; went himself 


\section{THE SECOND BATTLE OF YPRES}

before two in the morning to wake them and see that all was in workmanlike order, and told them to rush as though for their lives; to continue carrying, even though with every tyre bust-aye, even if they had to run the cars on their axles.*

Once again the Field Ambulance rose to the occasion : every case was successfully evacuated; not one wounded man was left behind. It was dawn next morning before the enemy discovered what had happened.

At ten o'clock Colonel Foster gave over the area to the D.M.S. of the 5th Army Corps, with, we can imagine, a heartfelt Nunc Dimittis. That afternoon he established his office in the sleepy little country town of Nieppe, some ten miles, as the crow flies, to the south of Ypres. On the night of the 3rd and 4th, the Ist Canadian Brigade marched to billets at Bailleul; the 3rd Brigade was withdrawn on the night of the 4 th, the 2nd on May 5 th.

The Canadian medical units, it will be recalled, had continued to serve until the 3oth, until the shelling out of their Main Dressing Stations gave the signal for withdrawal. That morning and afternoon, still under heavy fire, the stores and equipment were removed from Vlamertinghe, and the units retired to billets and much-needed rest, No. I Field Ambulance returning to Watou, No. 2 being parked at Ouderdom, and No. 3 at Hillhoek, to the south of Poperinghe, with A.D.S. near Busseboom. Nos. Io and I2 R.A.M.C. Field Ambulances remained to collect wounded from the roth British and Northumberland Infantry Brigades,

* I owe some inkling of what happened this night to the D.A.D.M.S., Major (now Colonel) Chisholm, D.S.O. 


\section{WAR STORY OF THE C.A.M.C.}

and No. I2 was transferred to work with the I3th Infantry Brigade.

It is doubtful whether any one unit of the British Expeditionary Force had during the first three years of the war tended, in the course of a week, a greater number of wounded $(5,200)$ than passed through the hands of No. 3 Canadian Field Ambulance during the course of the Second Battle of Ypres.* In all the units under the control of Colonel Foster, according to his report: "During the fighting from April 22nd to May 4th, on which date we were withdrawn from the 5 th Corps, the number of wounded handled by the three Canadian Field Ambulances, and the Ioth and I2th Field Ambulances of the $4^{\text {th }}$ Division, was 304 officers and 9,739 other ranks. Of these, 79 officers and I, 983 other ranks were Canadians." $\dagger$

In Canada we are apt to regard the battle as essentially Canadian. This, as indicated by the above figures, is very far from being the case. The Second Battle of Ypres was truly an Imperial undertaking, and should be so regarded. The undying glory of the Ist Canadian Division rests upon the noble defence and offence which they, untried troops, with no previous experience of war, put up forthwith on the afternoon of Thursday the 22nd, and throughout the terrible hours of the night of the 2and and 23 rd. From the late evening of the 22nd onwards,

* Later we shall have to point out how No. 3 Canadian Stationary Hospital in I9r 8 exceeded this record.

$\dagger$ This refers to the admissions to the Field Ambulances of the Canadian Division alone, and not to cases at the Advanced Dressing Stations, which passed back to British Dressing Stations and Casualty Clearing Stations. 


\section{THE SECOND BATTLE OF YPRES}

Lieutenant-General Alderson poured in continually increasing support until, not to detail the artillery and engineer brigades called into the fight, he directed some thirty-eight British infantry battalions and two cavalry brigades, in addition to the twelve infantry battalions and other units of the rst Canadian Division. The following figures taken from the returns of the A.D.M.S. Ist Canadian Division (Colonel Foster) are not a little illuminating :

\begin{tabular}{|c|c|c|c|c|c|c|c|c|c|}
\hline \multirow[t]{2}{*}{$\begin{array}{l}24 \text { hours up } \\
\text { to } 6 \mathrm{a.m} \text {. }\end{array}$} & \multicolumn{2}{|c|}{$\begin{array}{l}\text { Total Casu- } \\
\text { alties treated } \\
\text { in Field } \\
\text { Ambulances } \\
\text { of Division. }\end{array}$} & \multicolumn{2}{|c|}{ Canadians. } & \multicolumn{2}{|c|}{ Imperials. } & $\begin{array}{l}\text { Indian } \\
\text { Troops. }\end{array}$ & French. & Prisoners. \\
\hline & Officer & O.R. & o. & O.R. & o. & O.R. & O. O.R. & O. O.R. & O.R. \\
\hline 24 th. & 52 & 1372 & $4^{I}$ & 673 & II & 479 & -- & -216 & 4 \\
\hline 27 th. & 60 & $180_{4}$ & 6 & 260 & 54 & 1476 & -33 & - 34 & 4 \\
\hline
\end{tabular}

At Ypres, officers and men, we showed ourselves worthy of our citizenship and our comradeship, and from Ypres onwards the brotherhood in arms and mutual help has persisted and been intensified.

What lessons, it must next be asked, from the point of view of the Army Medical Service, are to be gained from a study of the battle?

In the first place, regarded broadly, the organization built up so carefully in times of peace showed itself efficient in the heaviest stress of war, both as regards its personnel and its methods. As to the personnel, both officers and men proved themselves wholly devoted and thoroughly capable, rising to each occasion, and working with splendid spirit night and day-and this was well recognized in official dispatches. 


\section{WAR STORY OF THE C.A.M.C.}

The following Honours and Awards were published in the London Gazette of June I8th, I9I5. I cannot find that the specific causes which it is usual to publish in connection with the award of the Distinguished Service Order and other honours have so far been announced. By permission of General G. L. Foster, who received the C.B. upon this occasion for his notable service, $I$ therefore publish the recommendations which he, when A.D.M.S., forwarded to the authorities :

C.M.G. : Colonel F. S. L. Ford, O.C. No. I Canadian C.C.S. (I).

V.C. : Captain F. A. C. Scrimger, M.O. I4th Canadian Battalion (I).

D.S.O. : Major H. A. Chisholm, D.A.D.M.S. Canadian Division (2).

D.S.O. : Captain T. H. McKillip, No. 2 Field Ambulance (3).

M.C. : Captain A. K. Haywood, O.C. 3rd Canadian Infantry Battalion (recommended by his O.C.) (4).

D.C.M. : Sergeant-Major (W.O.) A. E. Clifton, H.Q. SubStaff (5).

(1) Already noted in text.

(2) For gallant conduct and conspicuous bravery during the night of April 25th-26th at Wieltje and St. Jean, in taking charge of the clearing of the Advanced Dressing Stations at the above places at a time when they were being heavily shelled, wounding two medical officers and three orderlies and wrecking motor ambulance car.

(3) For gallant conduct and conspicuous bravery under heavy shell and rifle fire in the face of the enemy; with his bearers he removed and attended successfully at St. Julien, Wieltje and St. Jean, from April 22nd to 27th, 1915, until forced to retire from successive dressing stations becoming untenable. $\mathrm{He}$ removed all wounded without losing a case, nor having wounded men again wounded.

(4) Here should be added: Croix de Guerre, Major G. H. R. Gibson, M.O. 7 th Battalion.

(5) For bravery and cool devotion to duty under heavy shell fire in assisting in moving wounded to a place of safety from the church at Vlamertinghe on April 27 th. Subsequently granted a commission. 


\section{THE SECOND BATTLE OF YPRES}

\section{Mentioned in Dispatches}

Colonel G. L. Foster, A.D.M.S.

Lieutenant-Colonel A. E. Ross, O.C. No. 1 Field Ambulance (I).

Lieutenant-Colonel D. W. McPherson, O.C. No. 2 Field Ambulance (2).

Lieutenant-Colonel W. L. Watt, O.C. No. 3 Field Ambulance (3).

Major J. L. Duval, No. I Field Ambulance (4).

Major E. B. Hardy, No. 2 Field Ambulance (5).

Captain E. L. Stone, No. I Field Ambulance (6).

(I) For his unceasing toil throughout the action from April 22nd to April 3oth in caring for the wounded in the Field Ambulance Main Dressing Station, and coolness in removing all wounded on two occasions from his dressing station, which was shelled, to a place of safety.

(2) For his devotion to duty during action from April 22nd to April 28th. On the latter date the Main Dressing Station being shelled, all wounded were removed to a place of safety under the personal supervision of this officer.

(3) For great coolness and splendid ability in caring for large numbers of wounded from April 22nd to May 3rd. On three occasions the dressing station of this unit was shelled, wounding Lieutenant-Colonel Watt and Captain F. C. Bell on the last occasion, when it became necessary to remove all patients and close the dressing station.

(4) For gallant conduct and conspicuous bravery under heavy shell and rifle fire in the face of the enemy. With his bearers, removed and attended successfully at St. Julien, Wieltje and St. Jean, from April 22nd to 27th, 1915, until forced to retire from successive dressing stations becoming untenable. $\mathrm{He}$ removed all wounded without losing a case, nor having wounded men again wounded.

(5) For gallant conduct and conspicuous bravery at great personal danger while in charge of dressing station in Ypres. During the night of April 22nd-23rd, while his dressing station was repeatedly struck, he successfully collected, dressed and removed to a place of safety three hundred soldiers and several civilians. During the night he had seven N.C.O.'s and men of his section wounded.

(6) Showed great coolness and devotion to duty in clearing Advanced Dressing Stations of his area during the action of April 22nd to May 3rd. 


\section{WAR STORY OF THE C.A.M.C.}

Captain R. H. McGibbon, No. I Field Ambulance (7).

Captain J. J. Fraser, No. 2 Field Ambulance (8).

Captain G. P. Brown, No. 2 Field Ambulance (9).

Captain F. C. Bell, No. 3 Field Ambulance (ro).

Captain J. D. McQueen, No. 3 Field Ambulance (I I).

Captain H. H. Burnham, M.O. 2nd Brigade, C.F.A. (12).

Captain A. L. Donaldson, No. 3 Field Ambulance (1 3 ).

1825 Staff-Sergeant H. Butt, H.Q. Sub-Staff (I 4).

33259 Staff-Sergeant A. J. B. Milborne, No. 3 Field Ambulance ( 15 ).

33442 Staff-Sergeant A. E. Rotsey,No. 3 Field Ambulance(I6).

(7) Showed great devotion to the wounded in removing them from the aid posts during April 22nd to April 25th, on which later date he was wounded at St. Jean while bringing in a load of wounded.

(8) For bravery and coolness while in a position of danger, assisting Major Hardy at dressing station in Ypres during night of April 22nd-23rd.

(9) For gallant conduct and great bravery in collecting wounded on the Wieltje-Zonnebeke Road, April 24th to April 26 th.

(ro) For devotion to duty and bravery in assisting patients to a place of safety on night of April 3oth-May ist, on which occasion the dressing station was shelled, Captain Bell receiving a slight wound from a bursting shell.

(II) For devotion to duty and coolness in caring for patients at Advanced Dressing Station during April 22nd to 25th, during which time he was shelled out of three successive positions, and succeeded in moving all cases to a place of safety.

(12) Regimental recommendation.

(13) For devotion to duty and bravery in clearing Advanced Dressing Station at Wieltje during the night of April 24th-25th.

(14) For bravery in compiling returns throughout the action April 22nd to May $4^{\text {th }}$, during which time it became necessary to change the office five times on account of shell fire, to a place of greater safety.

(15) For unceasing and untiring work day and night in compiling records and returns of wounded for the 3 rd Field Ambulance from April 22nd to May 3rd, during which time this unit handled and evacuated some five thousand cases, and on three occasions the dressing station was shelled.

(16) For coolness and devotion to duty in operating room of Main Dressing Station of No. 3 Field Ambulance, April 22nd to May 3rd. 


\section{THE SECOND BATTLE OF YPRES}

32713 Sergeant T. Brown, No. I Field Ambulance (17). 32756 Sergeant W. B. Smith, No. I Field Ambulance (1 8).

32979 Sergt. J. W. Mackay, No. 2 Field Ambulance (19).

032773 Sergt. J. G. Kinsell, A.S.C., attached to No. 3 Field Ambulance (20).

1822 Quartermaster-Sergeant G, S. Cook, H.Q. Sub-Staff (21). 33394 Lance-Corporal W. McDonald, H.Q. Sub-Staff (22). 032744 Lance-Corporal A. Littler, A.S.C., attached to No. I Field Ambulance (23).

33461 Private H. G. Stewart, No. 3 Field Ambulance (24).

33280 Private A. Bartley, No. 3 Field Ambulance (25).

(17) For bravery and devotion to wounded on night of April $23^{2 d-24 t h}$, on being cut off from collecting station by shell fire ; remained with wounded near trenches all day, and brought all in safely to collecting station on night of April 24th.

(18) For bravery and devotion to duty in assisting Sergeant T. Brown in caring for wounded when cut off from collecting station by shell fire on night of April 23rd-24th.

(19) For bravery and devotion to duty on night of April 22nd23rd on duty in dressing station at Ypres, during constant shelling for hours, when three hundred cases were collected and dressed, and removed to a place of safety, receiving wounds from which he died two days later.

(20) For bravery and devotion to duty in charge of motor ambulance wagons of unit. $\mathrm{He}$ voluntarily drove an old motor-car three times into Ypres during an extremely heavy bombardment on April 23rd. He brought back three loads of wounded safely, but on the fourth trip the car was riddled by shrapnel and he was severely wounded.

(21) For unceasing and untiring work day and night in compiling returns of wounded, never quitting even under the heaviest shell fire, April 23rd to May 4th.

(22) For bravery and devotion to duty in conveying dispatches under shell fire from April 22nd to 28th, when he was seriously injured.

(23) He was unceasing in his devotion to duty day and night from April 22nd to 3oth, driving his motor ambulance wagon in answer to every call; volunteering to go into Ypres while the city was burning and under heavy shell fire.

(24) For bravery in collecting wounded April 23rd to $25^{\text {th, }}$ and removing them to Advanced Dressing Station at St. Jean.

(25) For bravery in driving horsed ambulance wagon under shell fire, bringing wounded from Aid Posts to Advanced Dressing Station at Wieltje. 


\section{WAR STORY OF THE C.A.M.C.}

33470 Private C. B. Tompkins, No. 3 Field Ambulance (26). 33358 Private R. L. Head, No. 3 Field Ambulance (27).

33408 Private A. Millen, No. 3 Field Ambulance (28).

33365 Private W. J. Holloway, No. 3 Field Ambulance (29).

33214 Private J. G. Youldon, No. 2 Field Ambulance (30).

33099 Private W. M. Leishman, No. 2 Field Ambulance (3I).

33047 Private J. Dalton, No. 2 Field Ambulance (32).

28722 Private R. W. Chester, No. 2 Field Ambulance (33).

33060 Private C. J. Farr, No. 2 Field Ambulance (34).

32922 Private E. Trotter, No. I Field Ambulance (35).

362 Io Private J. D. Sharman, A.S.C., attached to No. I Field Ambulance (36).

What is yet more to the credit of the organization is the fact, apt to pass unnoticed by the civilian, that the Second Battle of Ypres, unlike the engage-

(26) For bravery and devotion to duty at Advanced Dressing Station at St. Jean on April 22nd and 23rd. He was severely wounded while carrying a wounded man in to the dressing station.

(27) For bravery in collecting wounded and bringing them into Advanced Dressing Station under heavy shell fire at St. Jean on April 22nd, 23rd and 24th.

(28) Fearless, and frequently volunteered at critical times for any duty in collection of wounded at Advanced Dressing Station at Wieltje, April 22nd, 23rd and 24th.

(29) A brave and willing worker at Advanced Dressing Station ; wounded while bringing in a patient at St. Jean on April 23 rd.

(30) For bravery and devotion to duty as an orderly in dressing station at Ypres on night of April 22nd-23rd.

(3I) For bravery and devotion to duty as an orderly in dressing station at Ypres on night of April 22nd-23rd, when he was wounded.

(32) For bravery and devotion to duty as an orderly in dressing station at Ypres on night of April 22nd-23rd, when he was wounded.

(33) For bravery and devotion to duty as an orderly in dressing station at Ypres on night of April 22nd-23rd, when he was wounded.

(34) For bravery and devotion to duty in dressing station at Ypres on night of April 22nd-23rd.

(35) For bravery in rescuing wounded from burning motor ambulance which had been struck by a shell in St. Jean, April 24th.

(36) In bringing cases in from St. Julien he was absolutely fearless, and is a most valuable motor ambulance driver. 


\section{THE SECOND BATTLE OF YPRES}

ments which we shall have to chronicle later, was unforeseen and unprepared for. We shall, in future, have to quote operation orders-orders published by the staff well in advance of an engagement-in which the procedure of each branch of the Service is minutely detailed down to the roads and paths to be employed by the bearer parties of each division in removing the wounded. There were no operation orders for the events of April 22nd. There was, it is true, knowledge on our part that the enemy was about to use some poisonous gas, but no one knew what would be the effects of that gas, nor how he would follow it up. Add to this the Canadians had but just taken over the line and were barely settled in their trenches when the attack came. All this notwithstanding, stretcher-bearers and regimental aid posts, ambulances and advanced and main dressing. stations-one and all fell into line, and by the first night the evacuation of the wounded was proceeding with a rapidity and precision that would have done credit to old Service men.

As for the system, it proved itself elastic and adaptable, and, as already pointed out, such defects as showed themselves under the sudden and intense strain could be remedied, and were, in general, within a few hours. As an indication of the foresight that had been displayed, it deserves note that at all the ambulances the reserve medical and surgical boxes of dressings and drugs did not become exhausted, save in the one instance of the supply of iodine, which at this period of the campaign had not become so widely used, and supplied, as subsequently became the case. In this connection, it is as proper as it is pleasant to quote 


\section{WAR STORY OF THE C.A.M.C.}

from the Diary of Lieutenant-Colonel Chisholm, D.A.D.M.S., under the date April 24th: "One hundred stretchers and five thousand shell dressings arrived from stores. The large supply of Canadian Red Cross dressings on hand saved the situation."

It was by mere chance that the ist Field Ambulance was with the Ist Brigade, the 2nd with the 2nd, and the 3rd with the 3rd. Very rapidly the ambulances' services showed themselves to be not merely divisional, but Army Corps units, collecting and receiving the wounded from the area of operation, rather than from the division, while at the same time, as operating a particular area, the A.D.M.S. had placed under him three additional British ambulance units.

The outstanding weakness revealed lay in the supply of stretchers and stretcher-bearers. By the British system each battalion has sixteen stretcher-bearers, whose duties, as already defined, in addition to affording first aid to the wounded of the companies to which they belong is to convey the seriously wounded to the Regimental Aid Post. Before the end of the first twenty-four hours, it became evident that this number was inadequate. Four men are requisite for each stretcher. With a large number of seriously wounded and a long carry between the trenches and the R.A.P., not only are all the stretcher-bearers engaged in stretcherbearer work proper, to the exclusion of useful first-aid work, but they become thoroughly worn out by the heavy trudging to and fro. The Service stretcher, while soundly built and serviceable, is for this very reason a somewhat cumbrous load even when empty. It will be seen, by reference to map, that at the beginning of the action several 


\section{THE SECOND BATTLE OF YPRES}

R.A.P.'s were a mile distant from the trenches, the furthest two miles.

How were these difficulties to be met and obviated?

I. In later engagements we will see that there has been a steady tendency to shorten the distance of the hand-carry by bringing the R.A.P. nearer and nearer to the firing line. At Ypres, it will be remembered, not a few of the R.A.P.'s were attached to battalion headquarters. Now, where the enemy aeroplanes are flying overhead, there is more likelihood of the R.A.P. situated in this locality being shelled than in any position between it and the front line. There is, in fact, greater safety further forward. Nor is the regimental M.O. exposed to a more vital danger in this advanced position. His duty, while an action is in progress, is not to leave the Post;* he is the sole medical man in his zone, and must remain to treat the wounded as they pour in. The one admitted danger is that, as at Ypres, where a battalion has to retire, the seriously wounded and the R.M.O. may fall into the hands of the enemy. This admittedly is a grave disadvantage. It would be minimal were the Hague Convention respected, were wearers of the Geneva Cross, as non-combatants, promptly returned; were prisoners promptly exchanged who, on convalescence, were found of no further use, and were other prisoners afforded decent treatment. The agreement between British and German delegates meeting on Dutch soil recently, if ratified, should materially ameliorate conditions. In passing, it deserves note that

* This duty, however, was not emphasized in orders until some months after the Second Battle of Ypres. 


\section{WAR STORY OF THE C.A.M.C.}

Captain W. M. Hart, of the 5th Canadian Battalion, was released after eight weeks' detention.*

It is evident that the advantages of shorter carry, more rapid treatment and lessened strain on the bearers, all make for the good of the wounded, and outweigh the one disadvantage of placing the R.A.P.'s well forward; so that even when we do not deal with an advance, this should still be adopted.

2. As above noted, the squad for each stretcher is four men, and for a long carry this number is absolutely essential. Nay, more ; in addition, there should be two for relief. For a short carry two suffice. Our French Allies employ a light wheeled stretcher, with a pair of relatively high bicycle wheels, which is ingeniously underhung, so that a single man, after placing the wounded and his belongings on the stretcher while on the ground, can bring the pair of wheels over him, and by raising one end of the stretcher, hitch it on to the wheels and trundle him away. On a shell-pitted ground it is advisable to have a pair of bearers. But even then the number of stretcher-bearers is halved and the strain upon them very considerably reduced. In his report of operations, Colonel Foster offered as one of his suggestions, "that wheeled stretchers" be kept at the Advanced Dressing Stations of Field Ambulances, ready to push

* In his account of his detention Captain Hart reports that the General in command at Passchendaele assured him that he regretted that as a Medical Officer he had been made a prisoner; but that as he had been brought through his trenches and had seen behind the German lines, it became necessary to send him back to Germany, whence he would be returned to England. But what respect the enemy paid to the Hague Convention underwent rapid deterioration. Thus Captain F. Park, C.A.M.C., taken prisoner in June, 1916, was only released at the end of February, 1918. 


\section{THE SECOND BATTLE OF YPRES}

forward to Regimental Aid Posts, and, if necessary, to hand them over to R.A.P.'s, as they may be required, for their use."

3. But this does not wholly solve the difficulty. In wet weather-and in Flanders mud-with shell holes everywhere, the wheeled stretcher is useless. Yet another expedient has to be employed-that, namely, of increasing the number of stretcherbearers in each battalion, by training sixteen or thirty-two men selected by the O.C. as reserve stretcher-bearers, who, in emergency, may be called upon by the M.O., in sets of four as needed, to convey the seriously wounded back to the R.A.P. This demands that when proceeding into the trenches these sets of reserve stretcher-bearers carry with them additional stretchers. We will discuss this development further on.

4. It was suggested by the A.D.M.S., in his report, that each regimental stretcher-bearer be provided with a haversack containing first field dressings, a tourniquet (to control bleeding) and scissors.

5. Another valuable suggestion by Colonel Foster, which also has to a large extent been acted upon, was that each field ambulance be provided with a field kitchen. During the battle he had been afforded a very real proof of its great value. In the words of Major G. Garnet Greer, C.A.M.C.,

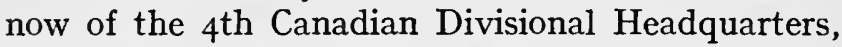
late R.M.O. of the 2nd Battalion: "Though not in the medical arrangements, there was a motor soup kitchen, operated by the Honourable Mrs. Massey, assisted by Miss Shillington and Miss Perry, all English ladies (unofficially attached to the 2nd Canadian Battalion), which did admirable work. These three ladies worked steadily day and night 


\section{WAR STORY OF THE C.A.M.C.}

during the battle, and, I am told, in one day fed with hot soup and cocoa over two thousand weary soldiers returning to their billets. Their kitchen was damaged by shell fire at this time, while it was situated in the northern outskirts of Vlamertinghe. This kitchen was the first I remember to do this very necessary work." Thanks to the generosity of Major Leonard, of St. Catherines, Ontario, three field kitchens were shortly after this supplied to the First Division. Placed at the A.D.S., and operating day and night, these supply to each man, wounded or sick, as he comes from the front a most welcome cup of hot broth, tea or cocoa, together with a biscuit. It is difficult to estimate what help and comfort these have brought to our men.

As I complete this chapter it is the end of October, I9I7, two years and a half after the events here recorded. Again the Canadians find themselves at Ypres; the old familiar names appear in the reports. Once again there are R.A.P.'s on Gravenstafel Ridge, collecting posts at St. Jean, and Main Dressing Stations at Vlamertinghe. But though by now the Canadians are war hardened, that Ypres country-side is for them no less sinister. On the contrary. "Never was it fair to look upon, this land of dykes and ditches, of mud and water, of miserable farms and miserable people, of flat acres bordered by straight trees, of dreary villages and squalid towns. To-day it is as if the curse of God had fallen there. To desolation is added the stench of death."* If this held true in I9I5, in

* A quotation from an article by "Sub" in the English Review, which I abstract from the private diary of Captain (now t,ieutenant-Colonel) P. G. Bell for June 5th, 1915. 


\section{THE SECOND BATTLE OF YPRES}

I9I7 the Ypres salient is more appalling, more hideously naked than ever. Under the incessant shelling of all these months no scrap of cover is left; everything is churned up until the roads are indistinguishable from the surrounding fields. Autumn days, perfect in themselves, yet of treacherous if presaging clearness, have alternated with spells of chill and heavy driving rain. The sodden ground has not been given time to dry, nor the floods to drain from the low-lying ground. There is mud unutterable everywhere-mud in which a man may sink, not merely to his knees, but to his shoulders; mud in which the badly wounded sink helplessly and add to the roll of "Missing" ; mud that makes movement so slow and difficult as-with six men to each stretcher carrying one wounded man-to demand six hours for the one journey from the front to the nearest collecting post and back, and shell holes filled with water so abundant as to preclude movement in the dark. But, notwithstanding, the Canadians are forging forward day by day, so that on the eve of this the anniversary of the critical day of the First Battle of Ypres they have grasped and hold the highest and culminating point of the ridge dominating Passchendaele-and the C.A.M.C. has shared in the credit, evacuating with a precision and expedition never before equalled. The name of Ypres is being hammered into the history of Canada.

Such are the difficulties surrounding publication in these war days that it is August, I9I8, when these pages reach me in proof for correction. And since last October for strategic reasons the 


\section{WAR STORY OF THE C.A.M.C.}

ground so hardly won by us at Passchendaele has been yielded again to the enemy. But Ypres and its more immediate neighbourhood we still hold and, what is more, now at the beginning of this fifth year of the war, hold with renewed spirit and determination. With the repulse of the enemy from the Marne to the Vesle and our advance in front of and below Amiens almost we hear the marching of our men forwards over those Flanders fields where lie so many whose blood makes the country around Ypres for all time a part of Canada.

Listen! dear dead who lie in Flanders fields, around St. Julien Wood, in Gravenstafel Ridge, at Wieltje and at Fortuin. Your brothers have not forgotten. We have not broken faith.* All Canada carries on the torch. And, comforted, give yourselves to sleep.

* "If ye break faith with us who die,

We shall not sleep, though poppies grow In Flanders ficlds."

It was an officer of the C.A.M.C. who wrote these well-known lines, now, alas, dead, one who went through the Second Battle of Ypres as Medical Officer of the Ist Canadian Artillery Brigade. As an old friend of Colonel John McCrae, as one to whom had been given the great good fortune of possessing him as colleague and fellow-worker for the past eighteen years, I may be partial. But for me, in all the outpouring of verse which has characterized these years of war, there has appeared no more perfect poem, no more flawless piece of artistry, than the fifteen brief lines of his Rondeau first published in Punch of December 8th, 1915. 


\section{CHAPTER IX}

\section{FESTUBERT}

ENGAGEMENTS so notable and so historic as the Second Battle of Ypres do not, as a rule, occur in rapid succession. Nor again, after men have received their baptism of fire, do subsequent experiences leave the same vivid impression. It is not unnatural, therefore, both that following the Second Battle of Ypres there was a period characterized by events which, in comparison, appear to be of minor interest, and that the documents in the case, the War Diaries, both official and private, become more commonplace, detailing routine movements and little beyond. Matters bearing upon the fortunes of the different units, in themselves of high interest, fail to be recorded, because, in the opinion of the writer of the diary, compared with the events at Ypres, they are not out of the ordinary, or, again, they have become everyday experiences and so pass without note. It is not, therefore, the fault of the historian if his narrative fails from time to time to maintain the same level of interest. Unlike the novelist, he cannot manufacture incidents out of his head : his record depends upon the material provided.

As already noted, on May 4th the 5th Army Corps took over the medical administration of the 


\section{WAR STORY OF THE C.A.M.C.}

Ypres area, and now a bare fortnight elapsed before the Canadian Division was again in action, strengthened by much needed drafts from the reserves left behind in Shorncliffe. This fortnight of mitigated rest was intensely appreciated by all in the medical service. The Ist Field Ambulance moved back to Watou, where throughout the battle one section, or a portion of the same, had carried on a Divisional Rest Station in the admirably appointed convent. Now for a week the whole unit ran the Rest Station, and though the work was easy, yet the position was not a sinecure. On May Ist there were 212 patients being treated. But on the 8th the whole unit moved to Bailleul.* The and bivouacked at Hillhoek, south of Poperinghe, for five days, but, doing this, it ran a Dressing Station for sick Canadians, and on May 2nd "C" Section established an A.D.S. a few hundred yards to the west of Vlamertinghe. The whole unit moved southward by night march on the 6 th. The 3 rd likewise moved to bivouac to the west of Poperinghe, but next day, May 7 th, " $C$ " Section moved to Bailleul, to join the Ist Canadian Infantry Battalion there, and opened hospital in the school building. But four days later all sections of this unit marched by night to Steenwercke, there taking over the hospital from the I2th British Field Ambulance.

But if thus their rest was mitigated, and a fair number of cases needed attention in the different hospitals, work in general was "pretty well over by noon." There was perfect May weather, and

* We shall have more to say regarding the Bailleul and Nieppe district at a later period; hence description will be deferred until then. 


\section{FESTUBERT}

the countryside was " becoming very beautifulfruit trees in blossom, lilacs and peonies. With the grain coming up and the whole countryside green, it is a vastly different scene from what it was in the winter."* And the roads about Bailleul and Steenwercke were good, winding and picturesque, with church spires rising here and there above the trees and forming a notable feature in the landscape.

Nor was the time without its events. On the afternoon of the I2th, General Porter, D.M.S. of the and Army, inspected each Field Ambulance, and at each, addressing all ranks, conveyed to them the message of appreciation of their services, which he had been charged to give by the Field Marshal Commanding-in-Chief. And his cordial words were as balm.

"He said that the work by the field units of the medical services during the Second Battle of Ypres was the finest ever done yet in any war. Twenty-seven thousand wounded were evacuated, and there were very few instances of the wounded being left out for many hours." $\dagger$ This acknowledgment of the work of the field units was over and

* I quote from the private diary of Captain (now LieutenantColonel) P. G. Bell, which at this juncture is redolent of the spirit of Major Sir Andrew Macphail's delightful essay upon "An Ambulance at Rest," which appeared in the British Medical Journal of September Ist, 1917. He writes of flowers and trees, warm days and winding roads, of the lovely garden at his billet and rides on "Ginger," of lying lazily in the sun, the deep unharried sleep of nights, a game of tennis at the Château and tea there, and evenings " strong on competitive solitaire. This evening we had the girls, our three old ladies and Madame from the Château to tea, and had an exceedingly merry time. Played solitaire until quite late." The blessed relief of it all !

$\dagger$ From the private diary of ${ }_{L}^{7}$ Lieutenant-Colonel P. G. Bell. 


\section{WAR STORY OF THE C.A.M.C.}

above a message received from Medical General Headquarters on the night of April 24-25th, complimenting the A.D.M.S. on the excellent manner in which the medical situation was being handled.*

Then there was preparation against gas attacks of the future. The immediate need for protection against the German gas was fully realized at Headquarters and by the War Office, and once the nature of the gas was determined, and the means of neutralizing its effects, an immediate effort was made to supply adequate masks. As early as Sunday, May 2nd, the men in the front-line trenches around Ypres were provided with masks, which, if not yet of the best type, nevertheless sufficed to save our men during the gas attack on that day against the $4^{\text {th }}$ British Division in the neighbourhood of Fortuin. It was close upon a fortnight after April 22nd, however, before these were ready for distribution in this area, and then only in quantities sufficient to supply those actually in the trenches along the British front, instructions being given that troops at rest should prepare their own masks. The A.D.M.S. records that in taking up this question with the Mayor of Nieppe, his wife very kindly offered to place her house at our disposal, she engaging some fifty sewing women and installing twenty-five sewing machines, we supplying the material. Needless to say, her offer was most gratefully accepted. Four days later, thanks to her whole-hearted co-operation, three thousand masks had been completed, and were delivered to the Ist Field Ambulance for distribution to the Ist Infantry and 2nd Artillery Brigades.

* With soldierly modesty, Colonel Foster does not report this in his official War Diary. I gather the fact from the private War Diary of Lieutenant-Colonel Chisholm, D.S.O., D.A.D.M.S. 


\section{FESTUBERT}

Following upon this respite, the Canadian Division took part in the series of engagements which are generally known as the Battle of Festubert. From a military point of view, it has to be confessed that the succession of actions extending from the 9 th to the 3 oth of May, while valuable, were not all that had been planned, even if, as Sir John French pointed out in his official report, we drove the enemy from a strongly entrenched position, and won ground on a front of four miles to an average depth of six hundred yards, capturing the entire first-line system of trenches on a front of 3,200 yards, and both first and second lines over the remainder. As compared with the Battle of Ypres of the preceding month, this was a turn of the tide from the defensive to the offensive. But, admittedly, we were out to win more, if possible to convert the previous failure in the same neighbourhood (at Neuve Chapelle) into a success, and secure the ridge which dominates Lille. Tactically, our offensive was undertaken in order to divert the Germans, and thereby aid our Allies in their advance upon Lens and other important actions in Artois, while the activity on the Western Front as a whole had the yet larger object of preventing further German troops being sent to the Eastern Front, where Von Mackensen was driving the Russians under Dmitrieff to the San.

As shown by the map, when the Canadians came on the scene, the British forces* had in the preceding nine days succeeded in reducing the projecting German salient, and in pushing back the enemy along a front of some four thousand yards, stretching from below Richebourg l'Avoué to

* Consisting of the Ist and the Indian Corps. 


\section{WAR STORY OF THE C.A.M.C.}

above Givenchy-lez-La Bassée. When the 3 rd Brigade was called upon to take part in the attack of May I8th, it ended the day by occupying the trenches in the central region, where the enemy had been pushed back furthest, occupying a narrow front which extended a bare half-mile between the Wiltshires on the right and the Coldstream Guards on the left-trenches which were from four hundred to six hundred yards in front of what had been our line at the beginning of the attack. To this attack we shall again refer. When upon the following day the Canadian Division formally took over the area, this front, as shown upon the map, was more than doubled. That map shows the disposition at midday on the Igth. In this more advanced position the ground in front of them was not as thoroughly known as this and other hard experiences during this first year of the war taught us was essential for complete success.

With regard to the medical dispositions, the point of foremost interest is the arrangement of the Main Dressing Stations. It will be recalled that eventually in the Second Battle of Ypres the A.D.M.S. had congregated all the M.D.S.'s at one centre, namely, in Vlamertinghe. We now find a test made of increased unity in action along the same lines, the first of many which we shall subsequently see culminating in the dispositions at Arras and the operations on the Somme. Namely, it was arranged that the tent sections and Main Dressing Stations of the three Field Ambulances should operate as a single unit. As the number of troops increases, with it increases the need for simplification of orders. From an administrative point of view, it is better, wherever possible, to 


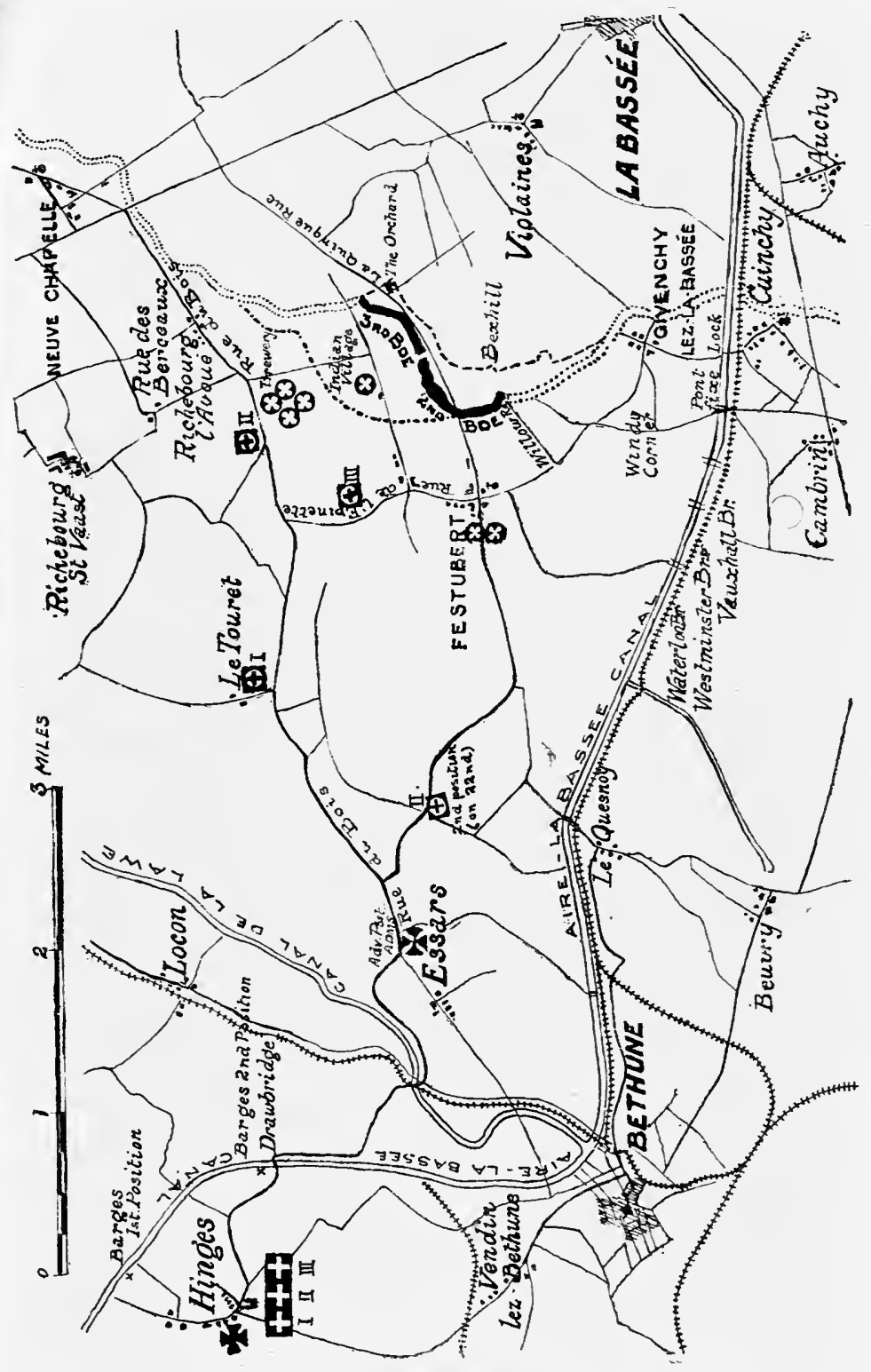





\section{FESTUBERT}

issue one order applicable to three brigades, than to make out diverse orders for each. It is better, for example, wherever this can be done, to direct all the wounded from the three brigades of a division to converge eventually upon one spot; it is both simpler and more effective to direct the motor ambulance convoy to work from one rather than from three localities back to the Casualty Clearing Stations, or, if they are needed to augment the work of the cars of the Field Ambulances, to have one rather than three M.D.S.'s to which they deliver the wounded. Even up to IgIo this could scarce have been contemplated; it would have entailed an undue length of haul by the horse ambulances. Now with the motor ambulance come into its own, this had become from every point of view the proper policy. It was these considerations that led the A.D.M.S. Canadians to initiate this change in the operations from May 18th to 29th inclusive: "Arrangements were made with the D.M.S. First Army to open the Tent Divisions of Nos. I, 2 and 3 Field Ambulances in the Château grounds at Hinges, our tentage being supplemented by tents taken over from the 7 th Division. This arrangement was very satisfactory." On the 22nd, the A.D.M.S. notes: "The Field Ambulances are handling their wounded easily in the tents and grounds, which lend themselves to the work most admirably. D.M.S. First Army* called this afternoon and seemed very well pleased with our arrangements."

* General Sir W. G. Macpherson, A.M.S., familiarly-and respectfully-known to the First Army as "Tiger Mac." There was no keener officer on the medical staff overseas than General Macpherson, and commendation from him was praise indeed. 


\section{WAR STORY OF THE C.A.M.C.}

It may be asked, did not difficulties arise in regard to this new disposition ? With three Commanding Officers, none of them before or after the other, who would assume supreme command? This difficulty was overcome with ease by so arranging that no one man had supreme command. The tents borrowed from the 7 th Division permitted the tent hospital in the Château grounds to be arranged on a threefold plan, so that the Field Ambulance units worked side by side, with an operating tent for serious cases in common, and another for walking cases. The motor ambulances delivered the wounded to each in sequence. There was thus no confusion and no question of relative authority. Another move in the same direction was made by placing the R.A.P.'s of the battalions of the 3 rd Brigade (which with the and was in the trenches) all together at "The Brewery." But this was dictated, in the main, not by considerations of policy so much as by the excellent accommodation afforded in the cellars of the old brewery. Nevertheless, the same idea was at work here also, as is shown by the fact that two of the three R.A.P.'s of the 2nd Brigade also occupied a site in common.

As regards the medical dispositions immediately behind the front, the three Field Ambulances took over the Advanced Dressing Stations from the 8th Division. These were situated at Le Touret, a little hamlet along the Rue du Bois, and by the side of Rue de l'Epinette, and served R.A.P.'s in the farm known as Indian Village, and others to the west of Festubert.

One further innovation is to be noted, namely, the introduction of hospital barges for the con- 


\section{FESTUBERT}

veyance of seriously wounded cases. It will be seen from the map that the Main Dressing Station at Hinges was within a mile of the Aire-La Bassée Canal. From the 24th onwards excellently appointed barges replaced motor ambulance cars for the conveyance of bad head, chest and abdominal cases. These did not, as might on first thought be expected, convey the cases back to the Casualty Clearing Stations at Aire, but took them the whole way down to the coast at Dunkirk or Calais, a three-days' journey. This voyage was made in the greatest comfort. Each barge had thirty beds, with a medical officer, four nurses and ward orderlies. It was further well equipped with electric lights and fans. At first all these cases were taken to the M.D.S. ; later, by making the mooringplace close to the drawbridge, patients were taken by ambulance from the front direct to the canal, and so were saved the extra two miles of motor carriage, their wounds being treated on the barge.

Some 250 yards in front of what became the centre of the Canadian right flank was an orchard, surrounded by a thick hedge, held by the Germans in considerable force. This from the first determined the activities of our men. As already noted, the British troops attacked this on the afternoon of May $\mathrm{x} 8 \mathrm{th}$, and the 3rd Canadian Brigade, which was still in reserve trenches, was asked to afford support. To this end the 16 th Battalion (Canadian Scottish) and the I4th (Royal Montreals) were directed to make simultaneously a flanking movement, advancing upon La Quinque Rue to the north of the orchard. Under a severe shell fire the frontal attack upon the orchard failed to materialize, but the Canadians gained some five hundred yards, and 


\section{WAR STORY OF THE C.A.M.C.}

proceeded to dig themselves in, in touch with the Coldstream Guards on their left flank,* whom they had joined in the advance. Upon the following day, the Igth, the Canadian Division took over the area from the 2nd Division, occupying front-line trenches that had been captured by the 2Ist Brigade, along with a section of trenches previously in possession of the $47^{\text {th }}$ Division. The map shows the extent of the Canadian front line on the evening of the Igth, with the 3rd Brigade to the north, the and to the south.

These two days were miserable with rain and cold. The resultant mud rendered the work of the stretcher-bearers very heavy. Each badly wounded man had to be carried back through the thick mud for more than a mile. But, as at Ypres, the regimental stretcher-bearers worked valiantly, well seconded by the Field Ambulance stretcher-bearers from the Advanced Dressing Stations. The Officers in charge, Captains J. G. Boyce (Ist Field Ambulance), McKillip and H. B. Jeffs (2nd Field Ambulance) and P. G. Bell (3rd Field Ambulance), who were largely responsible for keeping the Aid Posts clear, made frequent trips through the shell-swept zone, and by their coolness kept up the courage of the bearers, overcoming all difficulties during these first two days of the engagement. One and all were subsequently mentioned in dispatches. At night horse ambulances could be driven between

* The Coldstream Guards had fought over this country more than two centuries ago. La Bassée had been the Headquarters of Marshal Villars in his campaign against Marlborough in 1709, when his lines stretched from the Douai Canal at Annay, near Habourdain, by La Basseee, to the west of Bethune, and the Coldstreams were with Marlborough wlien he captured Bethune in 1710. 
Festubert and the R.A.P.'s at Indian Village, but, on account of the mud, only at a slow pace. From Festubert motor ambulances could be employed. Happily the weather improved on the 20 th and the roads dried rapidly; that night motor ambulances could be brought right up to the R.A.P.'s, save to that at Indian Village, which still could not be reached on account of the condition of the roads, and as the combined Main Dressing Stations in the Château grounds at Hinges were now in full working order, from this time onwards the evacuation and treatment of the wounded proceeded with the greatest smoothness. The wounded were evacuated by motor ambulance direct from the Aid Posts back to Hinges, those requiring re-dressing or adjustment of dressings being very few. This facilitated the work of clearing the front. The Advanced Dressing Stations received thus only the walking wounded, and were at no time crowded.

Late upon the 2oth, as the evening was closing in, after a lively bombardment by our artillery, which had continued all through the afternoon, a second and this time a successful attack was made upon the Orchard. To the I6th Battalion (Canadian Scottish), who had already distinguished themselves at Kitchener Wood, belongs the credit for the direct frontal attack, the I5th Battalion (48th Highlanders) being also engaged, and simultaneously assaulting a position some hundreds of yards to the south, while at the same time the roth Battalion (Manitoba) made an attack upon "Bexhill" at the southern extremity of our line. But the Bexhill redoubt was too powerful for us, and our troops there received terrible punishment from the German machine guns. The capture of the 


\section{WAR STORY OF THE C.A.M.C.}

Orchard, indeed, was by no means an easy matter. The rush forward of the Canadian Scottish was halted by the discovery of a wide ditch or small canal not noted on the maps, which disclosed itself unexpectedly, running between the attacking force and its objective.* The attacking companies had to plunge through this and scramble through a thick hedge, all the time under the fire of machine guns planted in the Orchard itself. But the impetuous rush of the I6th soon caused the guns to cease firing, and the whole position became and remained ours, despite a vigorous counter-attack by the enemy.

Following upon the attack on the Orchard the large number of casualties led to an appeal from the staff to the A.D.S. of the 3rd Field Ambulance for assistance in collecting wounded. Captain S. Alwyn Smitht (of Winnipeg), along with eight bearers, volunteered for this duty. Arriving, they found the Orchard still under heavy fire, so heavy that while removing the wounded four of the eight stretcher-bearers were wounded, two of them (Privates Ellis and Little) subsequently dying of their wounds. Captain Smith had done good, consistent work at Ypres; now, although only just behind our first line, and well in advance of the R.A.P.'s, he dressed each case personally and remained until all the cases had been collected by his own and other regimental stretcher-bearers.

* The country was of the Sedgmoor type, absolutely flat, with abundant watercourses. On the $I 7$ th inst. the $4^{\text {th }}$ Cameron Highlanders, on their advance, had similarly found themselves faced by a deep ditch which they had to swim.

$\uparrow$ Later Major and Chief Surgeon at the Granville Canadian Special Hospital; now seconded to the R.A.M.C. as Surgeon in Charge at the Military (Orthopædic) Hospital at Cardiff. 
For these services Captain Smith was subsequently awarded the D.S.O., while Acting Corporal H. T. Cameron, the Post Office orderly of the 3rd Field Ambulance, who was the first of the eight to volunteer their services on this occasion, received the D.C.M.

From a medical point of view there is little need to record in detail the succeeding ten days of the struggle at Festubert, and beyond the fact that the Orchard was retained in our possession, and that the Bexhill position, after intense resistance, was taken on the $24^{\text {th }}$, there was little of importance to note from a military point of view. Casualties there continued to be, but as compared with Ypres, on a moderate scale. The enemy made several counter-attacks, but these were all failures. Gradually the firing quieted down, and on the 26th Sir John French regarded the battle as closed. The Canadian Division was withdrawn and moved further south on the 3Ist.

As giving the impressions of a new arrival, of a regimental Medical Officer who had not previously been in action, there is a certain freshness in the following abstracts from the private diary of Captain G. M. Davis, * who was attached to the $5_{\text {th }}$ Battalion, to replace Captain Hart, taken prisoner.

* This cheery diary, indeed, with its paradoxical, yet not uncommon mixture of stoicism and epicureanism, of loyal performance of duty under all odds, coupled with a yearning for creature comforts and the good things of this life, has an added pathos. For its writer was one of the staff of the Hospital Ship Llandovery Castle, and as such a victim of Hunnish infamy in the last week of July, 1918. Born in 1874, he graduated M.B. Toronto, Igor. Practising at Welland, Ontario, he had volunteered in the first weeks of the war, being granted a commission in the befinning of September, 1914, and after 
"May 2oth (night of, after reporting to the A.D.M.S. at Vendin-lez-Bethune, and being consigned to the 5th). Went up six or seven miles in an ambulance. ... We passed over some high ground, and in front of us in an immense arc could see the shells bursting and the star shells like immense Roman candles being sent up from the trenches. . . . Reported to General Currie, and on to Headquarters 5 th Battalion. Found there was an attack being carried on. Helped at the Field Dressing Station (A.D.S. 2nd Field Ambulance) and then Captain Jeffs* and I went over to another Field Dressing Station, and found they were very busy. A regular stream of wounded coming in ; saw that they got the dressing they required and were sent back to the rear in ambulances. It was some night for my first experience. Got back about 3 a.m. . . Jeffs did not get back until 5 a.m. I relieve Jeffs and was very glad to see him again.

service on Salisbury Plain and elsewhere he went overseas to France in May, 1915. There he remained until invalided to England on sick leave in June, 1916. Here, after being attached to the office of the D.M.S. Canadians and of the A.D.M.S. London area in connection with the Standing Medical Board, he obtained his majority in January, 1917, and in March the same year was appointed to the Hospital Ship Service. He and Captain H. B. Jeffs were again associated on the H.M.H.S. Letitia, and both rendered distinguished service in the care and rescue of patients when that ship was wrecked on the coast of Nova Scotia in August, 1917. In the absence of any military decoration which could be applied in recognition of their conduct on this occasion, the Secretary of War directed that they be informed that he and the General Officer Commanding were fully sensible of the excellence of their service.

* Captain (now Major) H. B. Jeffs, of the 2nd Field Ambu-

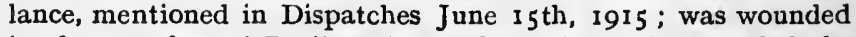
in the trenches of Pozières September 7th, 1916; awarded the Military Cross November I4th, I9I6. 


\section{FESTUBERT}

Many men had very bad wounds. Had no blankets, so went to bed in my British warm on some straw in a stable.

"2I.5.15. Behind the trenches about half a mile to a mile. . . . All day the artillery have been firing both shrapnel and high explosives. Last night two stretcher-bearers were killed and six or eight injured. It is a weird thing to see the shells bursting at night.

“22.5.I5. Time, 6.45 a.m. In a bomb-proof shelter and glad to be there. Five C.A.M.C. men and one other wounded in both arms by shrapnel. We have been smartly shelled since 6 a.m. Captain Jeffs and I worked all through last night. Had over eighty casualties. Have not had my clothes off since I came to the 5th Battalion. At 5.I5 last night Jeffs and I went out behind our D.S. and watched the fierce artillery bombardment of the German trenches, and it was a sight I'll never forget. The artillery had been bombarding steadily from noon till 8.30. Then they stopped and the infantry attack began. And then stray bullets began to whine by us and we went to our D.S. About 9 p.m. the wounded began to arrive, and we were busy till daylight. Had about an hour's sleep-then breakfast-and then they began to shell us and we were quite uncomfortable. It seems so odd, during the lulls of shell fire, to hear the birds singing just the same as usual.

"Well, I have had my bellyful of war all right. This morning's story runs like this: About 7 a.m. the Germans commenced to shell us with increased intensity up till noon-now and then a short lull, and our artillery for some reason was absolutely mum. Made us sore. In a short time we began to 


\section{WAR STORY OF THE C.A.M.C.}

get men wounded by shell fire with shrapnel and H.E. No ambulance would be allowed to come down the road during such a shelling; Jeffs had to go away and I only had my Medical Sergeant to help, and patients kept coming in. All told, between last night and this noon we treated ninety-five. Many were killed this morning. Amputated a leg, very nearly self-amputated, and I thought our house would collapse due to the H.E. shells. They are devilish. You hear the whine or shriek growing louder and louder, till at last it bursts with an earsplitting explosion, digs a hole three feet deep in the ground and about ten feet in diameter, and throws dirt, stones, etc. about one hundred feet into the air. This kind of stuff got closer and closer. Went up the road about four hundred yards to see Crozier* and his bunch, and found them in almost as bad a case as ours. Fortunately no shells hit near the road as I went up. But I lost no time getting over the ground, and I ducked for cover numbers of times. Came back and decided to stay where I was till forced to move. And this happened between twelve and one o'clock, when three H.E. shells exploded less than fifty yards away. Then we lit out quick-could take no equipment. We had to go about half a mile, and the first four hundred yards . were pretty dangerous. Splinters of shell were flying around. We had to lie down a couple of times, but fortunately not one round of shrapnel was fired, and our fourteen cases, including six stretchers and attendants, got away and not one was touched. Went up to the 7 th, 8th and Ioth First

* Captain J. A. Crozier, M.O. 8th Canadian Battalion. Resigned commission April, 1916. Mentioned in Dispatche June, 1916، 


\section{FESTUBERT}

Aid Dressing Stations, and some stayed there, but the rest went west for about five hundred yards, and I started up another First Aid Post, but didn't get many cases during the afternoon, as the stretcherbearers can't get at the wounded during the day, unless under exceptional conditions. Five lots of wounded were sent up by the F.A. Post run by Crozier, Gibson and Geggie, ${ }^{*} 7$ th, 8 th and roth, and mine, 5th. At one time during the p.m. I must have had forty stretcher cases and twenty-five or thirty sitting cases. The 6th London Ambulance took them to Bethune for us, and by 7.30 p.m. we had every case cleared out. No cases came in during this night. Slept in the cellar of what once was a fine brick house, now completely gutted; but all its walls nearly intact. Had a heavy thunderstorm during the night-rained very hard. The thunder plus the cannons made some combination. Rain leaked through the brick roof of cellar and I thought we were in for a soaking, but it only leaked in one place.

" 23.5.I5. A fine bright morning. Got up at 4 a.m. and moved back to close to Headquarters of 2nd Brigade about two miles away. My orderly got my horse on the way and I rode him the rest of the way. I did not like the way he acted. Had a sleep, breakfast, and a shave under difficulties. Went over and saw the battery near us. Had sick parade at 2 p.m.-about forty. Asked Colonel Luxford to let me have another horse, 'Pills.' He used to be Dr. Hart's, M.O. 5th Battalion, who was captured. The C.O. was quite agreeable, and so Foyle, my orderly, brought him up after sick

Captain R. C. G. Geggie, M.O. Ioth Battalion. Invalided to England, August, Igr 5. 


\section{WAR STORY OF THE C.A.M.C.}

parade, and I went for a ride of about six miles. Was pretty awkward, I guess. Entered at I2 p.m. in a dug-out covered with wheat straw. Got word that we are to attack at 2 a.m., and I got to the first line of trenches to establish a First Aid Post. Took the medical cart and the water cart. Distance is about three miles. Rode down. Was guided by Ptolemy, as I had to go into the trenches and look up Colonel Macdonell, L.S.H. Left the carts about half a mile from trenches. It was a beautiful, still, semi-moonlight night. As we went along we passed a great bunch of troops drawn up and standing alongside the road, waiting orders to march. It was quite a new sensation going along with an attacking party in real earnest. We were not fired on as we entered our trenches, though one shell broke near us. Was to report to Colonel Macdonell, but though I chased around the trenches for nearly an hour (and it is some job) I could not find him-so sent word to Major Edgar that our station was about seventy-five yards to the left of the Wieltje Road. Was awfully hot chasing through the trenches, dodging the obstacles, etc. I don't see that we can do effective work here, but will know for sure very soon.

"24.5.I5. Written in the second line of trenches. Attack started around 3 a.m. and was very quiet. I mean it was not preceded by the usual heavy cannonade, but the rifle fire and maxim guns were there right enough. Foyle and Hosie put the horses in as safe a place as possible, and then they hunt cover and await our return-in this case twenty hours or thereabouts. Was not very busy, but did quite a bit all the same. After the attack was over the cannonade started and it 


\section{FESTUBERT}

was pretty hot. The H.E. shells are terrific. The parapet of this trench, made of sand bags, was hit four or five times by H.E. shells. About Io a.m. we shifted our position about I50 yards, as our quarter was being shelled severely. It was a beautiful day, but not enjoyable. Gets quite cool as soon as the sun sets. You are redhot one minute, and glad of a heavy coat a little while after. It is fascinating to watch the H.E. shells burst, and a little of the thrill is in the fact that the next one might hit you.

"25.5.I5. A beautiful morning and a typical summer's day. Not a cloud in the sky. An aeroplane was sailing overhead at an immense height, and was being shelled by shrapnel. It was quite a sight. At least a hundred shells were fired, but as far as I could see it was not touched. The smoke made by these shells often makes rings and the smoke looks like fleecy white clouds, and stays visible for half an hour or more. The $5^{\text {th }}$ Battalion is very badly cut up. At present, I don't know what is the result of yesterday's attack. Had a quiet day. Wrote home. Had dinner about 7.30 p.m. Went to see a battery of howitzers near by, and had a talk and a cigar with their Major. It is a perfect night.

"26.5.I5. Another beautiful day. Had a wash in a tin biscuit-box and had breakfast about 9.30. The Germans are shelling heavily a place about two hundred to three hundred yards directly back of us with high explosive; and as I write this, about every half minute you hear the whistle of the shell overhead and the explosion about two seconds later. We go into billets to-day, and our billeting party has gone out to locate them for us. ... 


\section{WAR STORY OF THE C.A.M.C.}

We waited round till 9.35 p.m. before our Brigade pulled out. It was then fine and cool: rode my horse behind the 5th, but never got off a walk. Got a room for sick parade, and after getting something to eat about II.30, slept on a tiled floor: was very hard, but slept well. It was a very warm afternoon, and I'd have felt sorry for any troops that had to march during this heat.

"27.5.I5. Quite a change in the weather, and is now so cool that a raincoat feels comfortable. Not much doing this a.m. as all the men are going to the baths. In the p.m. I inspected the billets and found them so-so. Decided to try and locate a better sleeping-place, and found a dandy right across the road. Colonel Rogers, 2nd Battalion, had it, but is away. Got a feather bed! Hope I can manage to keep it. Have not been able to get into Bethune to get a bath. I don't need a bath so badly as I need a change of clothes."

The total number of wounded handled in the combined Field Ambulances was 996 Canadians of all ranks, and III British. Some of the wounds were very severe-were, in fact, the worst seen by our Medical Officers up to this point. The extensive laceration and the huge size of the wound of exit indicated that the enemy in certain of his battalions employed illicit projectiles; and this suspicion was verified by the discovery in the captured trenches of clips in which all the bullets had been reversed in their cases.

Lieutenant-Colonel D. W. MacPherson, O.C. 2nd Canadian Field Ambulance, reports in his War Diary : 
“ 22.5.15. 6.30 p.m. . . . Germans using ${ }^{7}$ gas again in this section, and rumours that dum-dum bullets are being used. ...."

"24.5.I5. . . . Attacking the Germans, who are using gas and dum-dum bullets, or bullets reversed in cartridge. A clip was brought into our Dressing Station to-day and I examined it, and

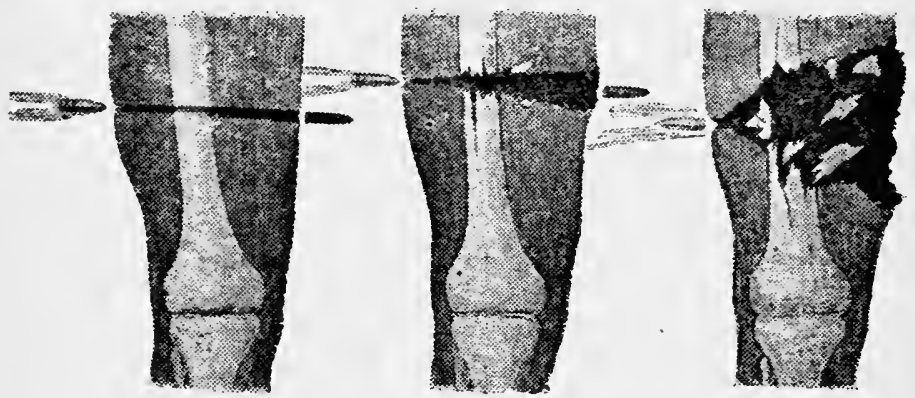

1. Nickel-pointed bullet with high velocity penetrates bone; small wound of entrance; very little destruction of tissue; wound of exit almost as small as wound of entrance.

2. Nickel-fointed bullet with less velocity fractures bone, and forcing fragments forwards causes destruction of tissue; wound of exit in consequence considerably larger than wound of entrance.

3. Reversed bullet; fair-sized wound of entrance; the soft metal of body of bullet mushrooms against the bone (as shown at $x$ ), causes great shattering of bone, and as the metal spreads it brings about great laceration and destruction of the soft parts, with gaping wound of exit.

confirmed it. ... Wounded coming in have very nasty wounds, the worst I have seen yet."

The effect of this reversal is obvious. The normal conical nickel-coated bullet penetrates and pierces the tissues in a wedge-like manner. If fired at close range it may not even fracture, but merely perforate, a large bone, and the fracture where it occurs tends to be simple, while the wound 


\section{WAR STORY OF THE C.A.M.C.}

of exit is relatively small. The reversed bullet, on the contrary, mushrooms out immediately it encounters resistance, and as a result there is terrible laceration of the tissues, with the production of a gaping, gruesome wound of exit.

Through the direct transport by motor ambulance from the R.A.P.'s to the M.D.S. the Advanced Dressing Stations received few serious cases; they became naturally what in later engagements were known as Collecting Posts for walking wounded. At first well forward, experience during this action showed that it would be well to have one or more of them further back. Thus the A.D.S. of No. 2 Field Ambulance, close upon a mile to the north of Indian Village, was so exposed that by the orders of the A.D.M.S. it was evacuated on the 22nd. And none too soon, for scarce had it been left when a shell completely demolished it. It was moved back some four miles to a point halfway between the front and Hinges, to a point easily reached from both the main roads leading from the Canadian front (consult the map). Here in addition it served as an advanced motor ambulance station, from which the ambulances could expeditiously move forward to clear the R.A.P.'s.

One other innovation deserves note. The endeavour to hasten up the evacuation of the wounded from the front, which led to the direct transport of the seriously wounded just noted from R.A.P.'s to M.D.S. without intervention of the A.D.S., was hampered by the distance at which the A.D.M.S. found himself from the front in his office at Hinges. It was important to have the office at the point upon which all the wounded converged, important also to be within easy reach of Divisional Head- 


\section{FESTUBERT}

quarters at Bethune, but it was equally important that the A.D.M.S. or his second in command, the D.A.D.M.S., should be sufficiently far forward to supervise the movement of the ambulance cars, and removal of the wounded to and from the front. This difficulty was overcome by establishing an advanced A.D.M.S. office at Essars, close to the junction of the two main routes of evacuation. In his report upon the operations at Ypres, Colonel Foster had called attention to the need that there should for effective work be a third officer on the staff of the A.D.M.S., and in response to his request, on 3 rd May, just before leaving Vlamertinghe, Major Snell, P.A.M.C., of the Second Field Ambulance, had been attached to his staff. It was this addition that made it possible to establish the advanced office, placing it in charge either of the D.A.D.M.S. or of Major Snell.

In his report on the operations at Festubert, Colonel Foster called attention to another administrative advance based upon the Ypres experience, namely, to the great assistance rendered by the Regimental Medical Officers in reporting to the Advanced Dressing Stations the conditions as to the number of wounded in their respective areas, and to the fact that by placing a senior officer at each A.D.S. to direct the ambulance service proper, the removal of the wounded had been greatly facilitated.

At the same time he again called attention to the need for wheeled stretchers. The long carry over the marshy ground was unduly hard upon the regimental stretcher-bearers : wheeled stretchers could have been used in this area with great advantage; throughout the action there had been 


\section{WAR STORY OF THE C.A.M.C.}

only three at his disposal. He recommended that the number authorized as at the disposal of each Field Ambulance be increased from three to five, these to be sent forward to the A.D.S. as considered necessary; as also that each regiment at the front be provided with one more wheeled stretcher.

These may to the ordinary reader appear to be matters of minor importance : they deserve record as indicating the constant attempt to secure increased efficiency on the part of the medical service, that is to say, the increased well-being of the men at the front.

As evidence of a rapidly vanishing state of affairs, one small contretemps may be given a passing notice. By the old pre-war system each Field Ambulance was associated with and was supposed to care for the wounded of its Brigade; it was, as a matter of fact, under the control of the Brigade Commander. It has already been pointed out that from the start this could not be the case with the Canadians overseas: we have seen how from the beginning of the action at Ypres the Canadian ambulance units received casualties of all orders, Zouave, Canadian and Imperial, until the Canadian admissions to the Main Dressing Stations of the Canadian Field Ambulances were, as it were, swamped by the admissions of British wounded. Now, at Festubert, with extension of the Canadian front southwards, it advanced across the front of the adjoining Imperial Division and the area occupied by the Field Ambulances of that Division, and this to such an extent that the Imperial troops to get into their trenches had to pass through the trench lines of the Canadian right flank (vide map). Thus, as the A.D.M.S. Canadians had not been 


\section{FESTUBERT}

permitted to move his Advanced Dressing Stations correspondingly southwards into the area of the adjoining Division, it was but natural that the walking wounded of the Canadian right flank made their way along the nearest road (Willow Road, which led away from the Canadian area) to the nearest A.D.S., which inevitably was that of the Imperials, and so to an Imperial Field Ambulance. This was the subject of a complaint to the D.M.S., the objection being made that the Canadian wounded were not being handled by the Field Ambulances of their Division. The case, it is true, differs from that at Ypres, inasmuch as technically all the casualties handled by the Canadian Field Ambulances occurred within what was still the Canadian Divisional area. It complicates Divisional returns if casualties from other Divisions have to be reported separately and accounted for. Nevertheless, wherever two Divisions come into touch with each other this interchange is bound to happen. As already noted, the Canadian Field Ambulances treated more than a hundred Imperial casualties during the Festubert engagement. The solution, as Colonel Foster pointed out, was simple, namely, to extend the Canadian ambulance area further southwards. But arrangements were already being made at this date to withdraw the Canadian Division in the course of a day or two, and the D.M.S., therefore, advised no change in dispositions. This is the solitary case on record of such a complaint. 


\section{CHAPTER $\mathrm{X}$}

\section{GIVENCHY}

ON the evening of Tuesday, the I5th of June, I9I5, the Ist Canadian Brigade found itself involved in one of the bloodiest engagements of the whole war. Over against its left flank was a German " "fortin," known to us as Stony Mountain, bristling with machine guns, guns which later did terrible execution. Before it, some 250 yards more to the south, was another strongly entrenched post known as "Dorchester." The operation orders directed that the 7th British Division on the Canadian left (with the East Yorks next to us) should make a frontal attack on Stony Mountain. The Ist Canadian Battalion (Ontario Regiment), under General Mercer, was to attack in support and secure the two lines of enemy trenches between Stony Mountain and Dorchester. Working parties of the and and 3rd Canadian Battalions were to secure and connect the trenches taken by the Ist, or, if necessary, assume the defensive.

The outstanding features of this engagement, namely, General Burstall's introduction of two eighteen-pounder guns into the infantry trenches as a surprise to the enemy; our too impartial mine in No Man's Land which injured friend and foe alike ; the deeds of individual heroism which over- 


\section{GIVENCHY}

lapped each other in the three crowded hours of strenuous fight: these, unfortunately for the reader, form no part of a medical history. They are mentioned to recall what a proud fight it was, even if it accomplished little, and even if it brought mourning to many. Suffice it to say that, with inadequate artillery preparation, Stony Mountain proved too strong a position for the 7 th Division : that the Ontario Regiment with the preliminary most effective work of the eighteen-pounders was not to be gainsaid, and swept irresistibly into possession of Dorchester and the German front trench. But the failure to reduce Stony Mountain rendered the Canadian position impossible. Exposed on the left, and with the captured trenches enfiladed by deadly machine gun fire from the German fortin, the Ontario men held on with constantly diminished numbers until, with scarce an officer left*, the survivors were forced to evacuate. The original trenches were now held for several days under heavy fire, until at the end of the month the Division was moved north.

From the point of view of the Army Medical Service, Givenchy is of interest mainly on account of the curiously narrow front served by the Canadian Division, and the changes that this entailed in the disposition of medical posts and medical units.

As indicated by the map (page I84), the area is but a few miles to the south of Festubert, and when at the end of May the Canadians were withdrawn from the latter district, they were given a front stretch of little more than one thousand yards

* Lord Beaverbrook points out that out of twenty-three combatant officers who went into this action, only three missed death or wounding. 


\section{WAR STORY OF THE C.A.M.C.}

north of the Aire-La Bassé Canal, a front so narrow that but one Brigade was needed to fill the trenches. That Brigade needed but one Field Ambulance to deal with its sick and wounded, and just as there was rotation in battalions manning the trenches, so now arrangements were made whereby each Field Ambulance in turn undertook work towards the front, week by week. Meantime the other two ambulance units undertook in turn the running of a Divisional Rest Depôt and care of the sick of one Infantry Brigade at Busnettes, some four miles west of Hinges as the crow flies, or went into somewhat incommodious billets at Gonnehem, some two and a half miles behind Hinges, tending the sick in that area.

The A.D.M.S. opened his office in an intermediate position, at Vendin on the outskirts of Bethune. Here at Vendin was subsequently established a Dressing Station for troops in that vicinity, served by the same Field Ambulance as was at Gonnehem.

With regard to the disposition of the Field Ambulance Stations, it is to be observed that the M.D.S. was considerably nearer to the front than was the case during the Festubert action. Its tents and marquees were pitched in a sand-pit at Le Quesnoy, south of the canal, two miles east of Bethune, in a country studded with hillocks rising out of the plain, with here and there small copses. It was, in consequence, completely screened from hostile observation, save from the air. Too well sheltered some thought, since in those June days the sand-pit took on the character of a Dutch oven, becoming painfully hot. But one cannot have everything. It evacuated to a British Casualty Clearing Station at Chocques, three miles to the west of Bethune. 


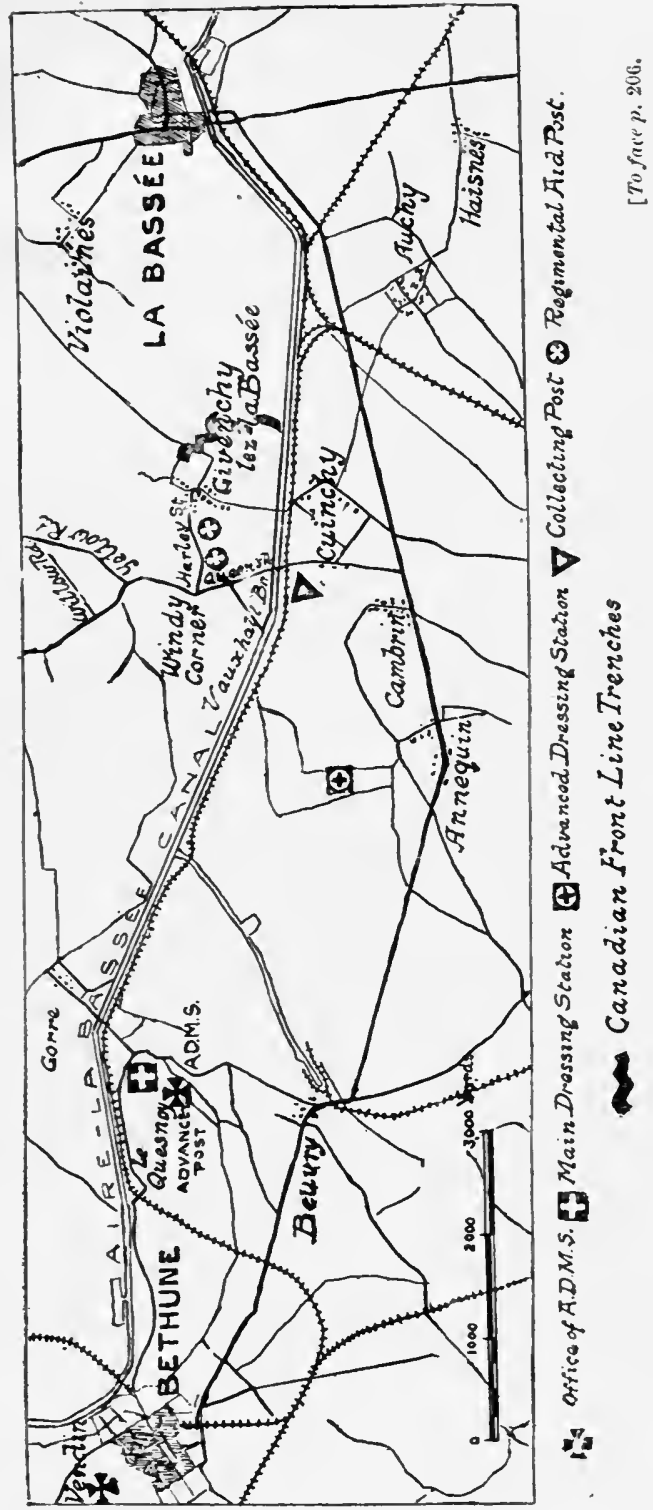





\section{GIVENCHY}

On the morning of the 5 th the A.D.M.S. inspected the M.D.S. of the Ist Field Ambulance at Le Quesnoy, and completed arrangements for handling the wounded at the front. Briefly these arrangements were the following:

The two Regimental Aid Posts were in houses on what, from their presence there, had come to be known as Harley Street, at a point some five hundred yards on this side of what had been the flourishing little town of Givenchy. This afforded a shorter carry for the regimental stretcher-bearers than at Festubert, and, with but one Brigade in action, abundant regimental stretcher-bearers were obtained by calling upon the different battalions in reserve and support to detail parties for the work. On the other hand, ambulance cars could not reach Harley Street : the canal bank at Vauxhall Bridge was the furthest point to which they could safely venture in the daytime. Sixty men of the Bearer Section of the Ist Field Ambulance, with wheeled stretchers, were therefore detailed to carry down the Queen's Road between the R.A.P.'s and the Bridge. Here an officer and party were posted to supervise the movements of the wounded, who, according to the nature of their wounds, either as walking wounded or in horsed ambulances, were directed to the A.D.S. at Annequin, where Major C. P. Wright* was stationed, charged with control of the wheeled stretchers and horsed ambulances, not of his own unit only, but also of the 2nd Field

* Major Wright, later O.C. Ist Field Ambulance and D.S.O., now Colonel, A.D.M.S. 1st Canadian Division, had only joined the Ist Field Ambulance at Festubert. He had a record of several years' good work in Canada, where he had been O.C the 7 th Field Ambulance at Quebec.] 


\section{WAR STORY OF THE C.A.M.C.}

Ambulance, from which additional transport had been detailed. More seriously wounded cases were taken by motor ambulance direct to the M.D.S. at Le Quesnoy. (After the first day of the engagement most of the ambulance cases were taken direct from Vauxhall Bridge by the CambrinBeuvry road to Le Quesnoy, and the A.D.S. again, as at Festubert, served mainly as a Collecting (and Dressing) Station for the walking wounded.)

With this, as a further means of controlling the situation, on the morning of the engagement an Advanced Medical Report centre (Advance A.D.M.S. Office) was established at Le Quesnoy under the D.A.D.M.S., and Colonel Foster himself came here in the afternoon.

These arrangements worked out excellently: at no time was there any delay in removing the wounded, once they had been collected by the R.S.B.'s, and the bearers worked up to within a few yards of the German trenches. The evacuation was most speedy and without a hitch. Indeed, from a medical point of view the arrangements made by the A.D.M.S. worked so smoothly that there is little to record save the nature of the same. From 6 p.m. on the I5th, when the action began, to midday on the I6th, II officers and 350 other ranks had been treated at Le Quesnoy. At Io a.m. on the I6th the R.A.P.'s were reported all clear.

Throughout the I6th there was considerable artillery and other activity, and the wounded continued to come in steadily. Three officers and I45 Canadians of other ranks, and seventy British O.R.'s passed through the M.D.S. Although the firing was heavy, the casualties were moderate during the following fortnight. 


\section{GIVENCHY}

For good services in this action Colonel Foster specially recommended the following: LieutenantColonel A. E. Ross, * Ist Canadian Field Ambulance; Major R. P. Wright, $\dagger$ Ist Canadian Field Ambulance; Captain J. C. Fyshe, ${ }^{*}$ Ist Canadian Field Ambulance; Major R. Raikes, $\uparrow$ M.O. 4th Canadian Battalion; Captain D. E. Robertson, ${ }^{2}$ M.O. Ist Canadian Battalion; Captain R. J. Gardiner, 3 M.O. 2nd Canadian Battalion; Captain J. H. Wood,4 M.O. 3rd Canadian Battalion; Captain C. E. Fortin, $*_{5}$ M.O. Lord Strathcona's Horse ; Captain J. H. Todd,* M.O. Royal Canadian Dragoons ; Lieutenant A. P. Reynolds,* R.A.M.C., M.O. 2nd King Edward's Horse.

In addition to those above noted, the following Officers and N.C.O.'s obtained recognition for their services : Captain P. G. Brown, ${ }^{*}$ 2nd Canadian Field Ambulance; Captain P. Poisson,* M.O. Divisional Engineers, and Sergeant O. Stenstrud, No. I Canadian Field Ambulance.

From the nature of the engagement the Regimental Medical Officers and those near the front bore the brunt of the fray, and this is reflected in

1 Now Major on the Staff of No. I4 Canadian General Hospital, Eastbourne.

2 Later Major, and in Canada. Mentioned in Dispatches, January, 1917.

3 Now Major on the Staff of No. I Field Ambulance. Awarded Military Cross, January, 1918.

4 Now Major, and Acting Lieutenant-Colonel on the Staff of No. 2 Canadian Field Ambulance. 19r4 Star and Croix de Guerre (Belgian).

3 After returning for duty to Canada he served with No. I Field Ambulance in 1916, and in 1917 was recalled to Canada for duty.

* Mentioned in Dispatches. t Awarded the D.S.O. 


\section{WAR STORY OF THE C.A.M.C.}

these lists. Here, as at Ypres and Festubert, the O.C. the Ist Field Ambulance showed himself absolutely devoid of fear and devoted to his duty. To co-ordinate the work of his unit with that of the Regimental Medical Services, Colonel Ross "made frequent visits to the A.D.S. and even to the R.A.P.'s, and materially aided the prompt evacuation of the wounded." And Major R. P. Wright well seconded him. Not satisfied with remaining at the A.D.S. at Annequin, he superintended the removal of the wounded across the canal at Vauxhall Bridge, "working unceasingly for forty-eight hours in a position which was under the enemy's fire, besides making frequent visits to Regimental Aid Posts "- -keeping these cleared. His work at the A.D.S. at Annequin, also under fire, was taken over by Captain J. Fyshe. Captain P. G. Brown, of the 2nd Field Ambulance, was of notable assistance in "removing his wounded from Harley Street to ambulance wagons at Vauxhall Bridge." Once before, at Ypres, his good work caused him to be mentioned in Dispatches. As at Ypres, Captain Poisson* of the Divisional Engineers, "was at all times ready and frequently volunteered to assist at Aid Posts which were under fire." Now he was mentioned in Dispatches. In this connection the A.D.M.S. gives high praise to Sergeant Stenstrud, $\dagger$ who was in charge of the stretcher-bearers of his ambulance unit. "He showed clear judgment in removing the wounded from the R.A.P.'s to Vauxhall Bridge, and over the canal to the ambulance

* Awarded Military Cross, January, I9r8.

$\dagger$ Now Quartermaster and Hon. Lieutenant, having been given a commission in November, 1917, and awarded the Military Cross, January, 1918. 


\section{GIVENCHY}

wagons, a very exposed and at times dangerous, area. The prevention of congestion and further wounding of the wounded was largely due to his vigilance and courage. He had displayed the same courage in his work at Festubert and Ypres."

The others mentioned are Regimental Medical Officers. Among these Major Raikes* stands preeminent, receiving the D.S.O. along with Major Wright. Before the war, Colonel Raikes had been a practitioner, known the whole countryside around, at Midland, on Georgian Bay, Ontario. When the war opened he was already a man of fifty-four years of age, but keen, alert, with clear eye and powerful constitution, a lover of open air, who could give the "go by" to men fifteen years his junior-a man who knew men. $\dagger$ For long years he had been M.O. of the local militia regiment, the $35^{\text {th }}$, obtaining his majority in 1908 , and in $\mathrm{IgI}_{4}$ he promptly volunteered for active service. Cheery and tireless, he exercised a remarkable influence over his brother officers and men. At Ypres, at Festubert, and at Givenchy, the greater the shelling the higher appeared to be his spirits, the further forward he found himself, so that he kept all around him full of courage and goodwill. This is the account that I, as historian, have received from all who came in contact with him, though from him personally I

* Now Lieutenant-Colonel, seconded for duty with Board of Pension Commissioners for Canada (British Branch) without pay and allowances.

$\dagger$ At Festubert, for example, one morning there appeared on sick parade no less than sixty-seven men of the $4^{\text {th }}$ Battalion, This would never do. He therefore instructed his batman, himself a character, to give out the rumour that they were to go into rest billets for a month. The sick parade next morning consisted of two men. 


\section{WAR STORY OF THE C.A.M.C.}

have been able to obtain no information regarding the doings which brought him the D.S.O., save that the trenches at Givenchy were excellent and deep, so good that they were the show trenches round which to conduct Members of Parliament and suchlike. That, he pointed out, explains why he so frequently accompanied his O.C. through them! 


\section{CHAPTER XI}

" PLUGSTREET"

Picture to yourself a district some ten miles across from north to south, in its southern half almost flat, and, if I may so express it, Flanderish, in its northern half more undulating, with a succession of knolls overlooking the flattish land held by the enemy.* Those knolls may, some of them, be justly dignified with the name of hills, although in Flanders elevations of inferior virtue are granted this name. Any elevation thirty feet or more above the surrounding country may be of high military value. An elevation of three hundred feet and more above the general level, like Kemmel mountain, or even of some two hundred feet, like that of La Hutte (Hill 63), over against Messines, is a great asset. These overlook the enemy; they dominate for several miles the plain which stretches to the south, and so render that reasonably secure from invasion. Our possession of this higher land explains why for long months nothing particular happened in this district. Near and tempting as Messines $\dagger$ looked, with its roofs and church spire,

* Consult map at end of this volume, under the cover.

$\dagger$ Was it not for Uncle Toby's siege of Messines that Corporal Trim appropriated the ancestral Shandean jack-boots to convert. them into mortars? Sterne, it is true, writes it "Messina," but the siege of Messina was largely a naval affair, and had nothing to do with Uncle Toby's Flanders experiences. 


\section{WAR STORY OF THE C.A.M.C.}

when seen from Hill 63, or even from the Plugstreet trenches, we were not prepared to take the offensive and break through along the front; we knew that Messines, upon its rise of ground, was strongly defended. The Germans, on their part, were not prepared to make an attack uphill on our strong points. Thus it was that after Givenchy, when at the end of June the Canadian Division was transferred from the $4^{\text {th }}$ Corps of the Ist Army to the 3rd Corps of the 2nd Army, and took over what for convenience we may term the Plugstreet area, there ensued a protracted period of trench warfare, a period of close upon nine months characterized by no serious engagement, by sniping, by surprise raids (and it was the Ist Canadian Division that carried out the first of these), by each infantry battalion in succession coming up at night through the communication trenches in Indian file to relieve another battalion, remaining in the trenches for several days (the time varying according to the season), to be relieved in its turn one welcome night by a fresh battalion, and to plod its way back to billets, there not so much to rest as to be bathed, and given a change of underclothing, and steady daily exercise, not to mention fatigues of various orders. This until in March the division was replaced and sent north. It was a period characterized further by the expansion of the original single Canadian Division into three divisions, and the development of a Canadian Army Corps, with all that this necessitated in the matter of altered and extended administration. But of this more anon in another volume.

The centre of the new Canadian area was Bailleul, a thriving little old-world country town of some 
ten thousand inhabitants, just over the border in French Flanders, with its streets radiating irregularly from a large roughly-paved central square, or, more accurately, long oblong, the scene of the weekly open-air market for all the country round; with the Hôtel de Ville on one side, uninteresting save for its campanile dating from the time of the Spanish possession, the old-fashioned and not particularly interesting hotel on the other, and the chief notarial and other offices and shops all around. Just behind the Hôtel de Ville is-or was-the Church of St. Vaast, with the triple nave characteristic of church architecture in Southern Flanders." The front was some seven and a half miles distant.*

* Bailleul, according to $\mathbf{M}$. de Coussemaker, was sacked by the Normans in 882, and by the English in 1434. Sir Anthony Bowlby, I learn, has suggested that we of British blood are very directly interested in Bailleul, in that from it came the founder of Balliol College, Oxford (the said founder's father, in expiation for his misdeeds, had been publicly whipped by the Bishop of Durham before the cathedral door, and therewith promised moneys for the support of certain poor scholars at Oxford), not to mention John and Edward Balliol, the successfnl competitors, as against Robert and David Bruce respectively, for the crown of Scotland.

Without doubt, the Balliols were descended from Guy de Baillenl, who came over with the Conqueror, but unfortunately there are some thirteen towns and villages of the name of Bailleul, and the ancestral lands of the Balliols in France, to which King John of Scotland was permitted to retire after the Hammer of the Scots, Edward I., had imprisoned him in the Tower, were at Bailleul en-Vimeu in lower Picardy, six miles south of Abbeville.

Nevertheless, it is just possible that the Balliol family came originally from our Bailleul in the Pas de Calais, and gave that name to the Picardy estate. Bailleul (Nord) has been an important place since the ninth century, and was the seat of a powerful family. In 1064 Regnault de Bailleul of this family 


\section{WAR STORY OF THE C.A.M.C.}

In order to be nearer to that front, both General Alderson, in command of the Division, and Lieutenant-Colonel Foster, the A.D.M.S., were established at Nieppe, another and smaller country town or large village on the road to Armentières, the one feature of which is a moated late eighteenth-century Château, which was converted into the Headquarters of the Division.* Other places of some importance in the area were Steenwerck, behind Bailleul, and Neuve Eglise, a good-sized village, with a fine church with triple aisle like that at Nieppe, but finer, which, while not so important, occupied on the Canadian side somewhat the position that Messines occupied on the German. It was so near to the trenches that the enemy could see and shell anyone venturing along the middle of the main street. Locre, Dranoutre and Westoutre were villages

married Emerie, niece of Roger de Montgomery, one of the foremost of the Norman nobility, who led the centre at the Battle of Hastings ; thus the family had Norman affiliations.

Later, Baldwyn de Bailleul was Marischal of Flanders under Count Guy. It is at least suggestive that a coat-of-arms, which is that of the Balliols, was during our occupation of the town still to be seen on the front of the Hôtel de Ville at Bailleul. Certain families of Bayley also claim origin from Bailleul.B. J. Scot, " The Norman Balliols in England."

* Canadian Headquarters were established at Nieppe only by courtesy, this town being outside the Canadian military area. Nieppe had been in possession of the Prussians for a few hours in September, 1914, this being the limit of their westerly advance. The Uhlans had collected all the cattle from the surrounding country into the town square, and then. had broached the cellar at the Château, and there indulged, as all the evidence showed, in a hideous drunken orgy. They were not so drunken, however, as to be unable to mount horse and ride away hurriedly when the immediate presence of the British was announced. But they left the cattle behind, and had no time to do any damage to the town, save to the Château wine cellar. 
further back. To the north was Kemmel, with its mountain (four hundred feet) and the range of hills passing in a westerly direction, with Mont Rouge (over three hundred feet), Mont des Cats (close upon five hundred feet), etc.

The trenches took their name from Ploegstaert, a country village, whose church, with a fine spire, some 2,500 yards back from the trenches, was a notable object for miles around. This village inevitably became "Plugstreet." Stretching to the north as far as the outskirts of Messines was the Plugstreet Wood. Previous divisions which had held the area had christened and placarded the various roads and communication trenches with familiar names: Hyde Park Corner, Piccadilly, and so on, down to Mud Lane.

When they first took over, the Canadians occupied the trenches between the WulverghemMessines road and the most easterly extremity of Plugstreet Wood, a distance of some three miles. Later, towards the end of September, when the and Division joined, the line was extended north to a point half-way on the road between Wytschaete and Vierstraat, and south for another half-mile or so down to the road running from Ploegstaert to Warneton. [Consult the map at the end of this volume.] The original trenches were overlooked somewhat by the high ground at Messines, and were reached from the wood by deep communication trenches. Back of the main trench each battalion had a dug-out for surgical repairs, and, in addition and further back, an Aid Post.

The medical care of the area was at first distributed between the $e_{2}$ three Field Ambulances of the 


\section{WAR STORY OF THE C.A.M.C.}

Division in rotation, one being given charge of the front area, another of the Divisional Rest Station, while the third ran a Corps Convalescent Depôt in a commodious old house and tents at Bailleul.

In the front area the A.D.S. was situated off the road one hundred yards or so from Hyde Park Corner, and just within the wood clothing the side of "Hill 63." Of all medical posts at the front, this most recalled Canada. There, sheltered by the hill and beneath fine upstanding trees, was a long, low log hut of three rooms. Curiously enough, it had been built, not by Canadians, but by a British north-country unit. Although well forward, indeed within fifteen hundred yards of the first-line trenches, it was well sheltered by the hill, and while shells repeatedly fell into the meadow in front of it, killing occasional horses, only once during all the months it was occupied did a shell fall into it, and then into the central room when this was unoccupied, injuring no one.

The Main Dressing Station occupied a farm, at Romarin, using tents as well as an estaminet at the cross-roads. In the garden behind the estaminet there grew slowly but surely a carefully-tended Canadian cemetery.

The Divisional Rest Station was opened up in tents at a farm two miles south of Bailleul, but soon was removed to near Steenwerck. It accommodated $5_{50}$ patients-patients with ailments not sufficiently serious or long-continued to necessitate transportation to the base and consequent loss to their battalions.

At the Corps Convalescent Depost in Bailleul were treated conditions of a somewhat similar order but 
milder, not only Canadians, but men belonging to the Ist Army Corps suffering from P.U.O. (slight fever of undetermined origin), trench feet, etc., needing but a few days' care and supervision. Here was accommodation for 250 patients in what must in its time have harboured one of the first families of Bailleul, one of those well-built, comfortable and roomy eighteenth or early nineteenth century houses, such as one meets with in French country towns, with courtyard and out-houses. The patients here, as being mild cases, were given not beds, but stretchers on trestles with army blankets.

When in the middle of July the Canadians were transferred to the and Army Corps, the Divisional Rest Station was given up, and now two Field Ambulances participated in the work at the front; the 2nd Field Ambulance moving up from Steenwerck to establish a Main Dressing Station in tents off the main road between Bailleul and Messines, to the south of Neuve Eglise, in what came to be known as Aldershot Camp, establishing an A.D.S. about half-way between the A.D.S. at Hyde Park Corner and Neuve Eglise. With this the other Field Ambulance unit in Bailleul ran a combined Divisional Rest Station and Corps Convalescent Depôt.

These summer months in the Plugstreet area were a time of comparative rest. Although in the rains of the winter months the soil melts, and the mud in the trenches is unutterable, in summer the soil is easily worked, and our men lived in clean, deep trenches fairly safe from snipers. Indeed, up to the end, until Messines was blown up and the Germans withdrew further westwards, such was its configuration that this had always been 


\section{WAR STORY OF THE C.A.M.C.}

a relatively quiet area. When in our possesșion the front line and communication trenches were deepened and greatly improved, board walks were put down, drainage pits dug, and stringent regulations enforced regarding the use and cleanliness of the latrines and removal of waste.

There is a strong temptation when down in a trench to throw empty meat and fruit cans and remains of food over the parapet in front or parados behind, where " out of sight is out of mind," and to provide thus abundant food and breeding-ground for flies. Acts of this nature were strenuously prohibited. Garbage was carefully and regularly collected, and, as a result, the plague of flies was kept down to a remarkable degree.

To get rid of rats was a more difficult matter. From the deserted farms and all the countryside rats were attracted to the trenches in extraordinary numbers, and their calm boldness was beyond belief. The better the removal of the garbage the greater their depredations in the dugouts. No foodstuffs were safe from them unless firmly covered over.* Traps were of little use : the rats rapidly educated themselves to understand their meaning. The introduction of dogs and cats was without avail ; these became sleek, surfeited and lazy, and the number of rats showed no serious diminution. Indeed, so far as we can learn, the problem how to exterminate these pests still awaits a satisfactory solution, and there have developed trench philosophers who hold that as scavengers they are a positive advantage! The

* One humorist was so impressed by their pertinacity as to declare that they soon learnt to know the better brands of canned goods, and eventually carried off the unopened tins. 
pathologists accuse them with not a little force of being through their parasites the carriers to man of trench fever and infectious jaundice.

The water-supply came in for unremitting attention. We have by now come to treat as a commonplace the marvellous fact that in a country of stagnant water and shallow wells, a country that should be the ideal home of enteric fever, one in which, as a matter of fact, the civil inhabitants at the time became victims to enteric fever by the thousand, this disease was curiously infrequent among the Canadian forces. The total number of cases of typhoid during the year I9I5 among the Canadian troops in France was ninety-nine, with three deaths; of Paratyphoid A, thirty-nine, with one death; of Paratyphoid B, one with recovery; and it is worthy of note that the unit which supplied the greater number of typhoid cases was that which had been the first to leave Canada, and this before inoculation had been made compulsory, namely, the gallant "Princess Pat's."

It might be urged that these results were due entirely to the antityphoid inoculation; that the inoculations which the majority had undergone, against enteric alone, protected them against paratyphoid conditions also. Now there is a certain amount of evidence that inoculation against one of this group of diseases protects against, or mitigates the severity of the attacks due to the other members of the group. But simultaneously summer diarrhœea was extraordinarily rare. These latter facts can only be ascribed to one cause which must have been an adjuvant factor in the suppression of the typhoidal conditions, and that one cause 


\section{WAR STORY OF THE C.A.M.C.}

is the chlorination of the water-supply of all troops.

In Canada, in the years immediately preceding the war, we had learnt the value of the process. So excellent is the sanitation in Great Britain, so great the care taken of the water-supplies, that there typhoid or enteric fever has during our generation been almost exterminated. It is rare to encounter cases in the wards of a civilian British hospital. In Canada, as a young and still developing country, this cannot be said. The disease had been always with us. Regularly each autumn the disease showed itself, and since I 900 there had been a succession of grave epidemics affecting thousands in Winnipeg, Ottawa, Toronto and Montreal (to mention only the larger cities), always traceable to defects in the water-supply. By the process of chlorination these, since I9Io, have been controlled in a most striking way. With the treatment of the water-supply, epidemics had been suddenly. cut short, and for the first time in their history hospitals in cities like Montreal had only cases that came from outside, or that had exposed themselves to infection outside the city limits. And we had learnt that the process needs the strictest care; that anything like rule-of-thumb addition of the hypochlorite is followed by disaster; that the amount of organic matter in a water-supply may vary from day to day-indeed within the course of a few hours, thus necessitating periodic tests by experts, both chemical and bacteriological, and demanding variation in the amount of hypochlorite to be added.

This experience prepared our sanitary officers to put into operation a most rigorous control of all 
possible water-supplies. The first duty of the sanitary section attached to the division came to be to obtain samples from all wells, pumps, streams and other sources of water; the main work of the mobile laboratories established at the front to examine and report upon these samples, both chemically and bacteriologically. According to the results of these examinations, certain sources are declared unfit for drinking purposes, and are so labelled, sentries being placed over them to prevent their use. Others are declared fit for use, and then daily samples are taken, by a rapid and simple method the amount of organic matter is estimated upon the spot, and hypochlorite added to the water in the water-carts in accordance with the findings.

But apart from the quality, the quantity of the water was a matter at times of grave concern. To-day the engineers think as little of running a line of water-pipes up to near the front as the Army Signal Corps thinks of running electric wires, and if a chance shell breaks the line and interrupts the supply, the pipes are relaid and the supply re-established with almost the same expedition as the surface telegraph wires are mended. We had not reached this perfection in 1915 , and as the summer advanced, the shortage of serviceable water on the Plugstreet front was a source of grave anxiety. The War Diary of the A.D.M.S. contains repeated reference to this matter. The supply at Bulford and Aldershot camps in particular was perilously low. The only wells in the neighbour. hood were at Neuve Eglise. Here, at first, hand pumps were-installed and the water piped along the roadside. But as Neuve Eglise was being 
WAR STORY OF THE C.A.M.C.

steadily shelled, the supply, when at length the pumps were installed, was what might be termed spasmodic.

In July the situation was serious; in September it had become acute. Major Amyot,* O.C. Sanitary Section, reported then to the A.D.M.S. Ist Canadian Division that many of the wells were dry or drying up, and of those still effective few were in good condition. "Chlorination," he remarks, "may make a drinkable water safe, but it cannot make a drinking water out of sewage, and many of the wells about here have more sewage in them than can be made safe." Thus the water-carts had to go miles afield for their supplies, to Pont de Nieppe, Steenwerck, Nieppe, Bailleul, and into the area of the rath Division, to get even a modicum of what was needed. The men were suffering from want of water for washing, and the horses equally from the sewage-contaminated ditch and swamphole water they were forced to drink.

The pity was that all this was unnecessary. There was, as the O.C. Sanitary Section pointed out, abundant water to be had by sinking wells, but the division did not possess an American drilling outfit. And now, when the situation was most acute, abundant good water was found running to waste within a few yards of Bulford Camp. A week after writing the report above quoted Major Amyot records in his official diary that a plentiful supply of good water had been found. It had

* A leading Canadian sanitarian, in civil life Professor of Hygiene in the University of Toronto, and for long years connected with the Board of Health of the Province of Ontario; now Sanitary Adviser to the D.M.S. at London Headquarters, Lieutenant-Colonel and C.M.G. 
been noticed that all through the summer, when other ditches and ponds were drying up, the brook which ran round the base of a hill on the other side of the road from the camp, while little more than a meagre trickle above the camp, remained a considerable stream below. And it was discovered that the lower strata of this hill formed the natural collecting pit of the countryside, and that clear good water was constantly escaping from them and supplying the stream. All that had to be done was to dig a collecting trench along the base of the hill, between this and the brook, puddle the further side, fill in with gravel, etc., and with a tile drain lead off to a reservoir, install a pump leading to a distributing tank, and from now on the water difficulty was at an end. But while it lasted it was a source of constant anxiety.

This matter of drinking water leads naturally to the consideration of water for ablution purposes and personal cleanliness, and that inevitably, when dealing with troops in the trenches, to the big but most unpleasant problem of body lice and their extermination. Lice, to employ the expression of the present Vice-Chancellor of Cambridge University, have been foremost among the " minor horrors" of all campaigns; given conditions in which removal of underclothing can only take place at long intervals, and a succession of men to occupy the same dug-outs and sleeping berths after the manner of Box and Cox, and these wretched parasites pass from one to the other until whole battalions are involved and made irritably self-conscious.

An important problem of the first years of the 


\section{WAR STORY OF THE C.A.M.C.}

war was, therefore, how to circumvent these miseries. Now, though we speak of body-lice, doing so we employ a misnomer. Unlike the itch parasite (of scabies), the habitat and breeding-ground of these lice is not the body but the clothing. It is to the clothes they cling, even when they take their two meals a day of their host's blood, and in the clothes and particularly along the seams that they lay their eggs. Strip off the clothing and forthwith the man is free from the pests. These facts in natural history were rapidly acquired by our troops, and of a warm summer morning those first two years of the war numerous Murillo-like figures were to be observed behind the lines making a practical application of their knowledge. From an administrative point of view, it became essential to install divisional bath-houses, in which battalions could be given hot baths by fifties and hundreds, and to combine with these distributing centres for complete changes of underclothing. Thus all along the British front disused breweries and other industrial establishments were converted into bath-houses, filled from morning till night with successive squads from battalion after battalion. Rapidly all along the British front the divisional bath-house developed a common ritual: the squad of fifty or so men are ushered into Room I, where they strip, place their underclothing in one pile, their boots, trousers and tunic in the other. From here they pass to Room 2, where are the baths, whether individual tubs, or metal baths large enough to hold two at a time, or mash tubs that will hold a dozen, all provided with abundant hot water, and after the joyous luxury of soap and water, they make their way to Room 3, where 


\section{"PLUGSTREET"}

they dry themselves and receive a complete change of underclothing. The discarded underclothing is first steeped in a solution of creolin, or other coaltar disinfectant, for some hours, and then passes through the hands of a staff of women of the country, who wash and laundry it, passing it on to another staff of darners and menders.

This periodic change of underclothing does much to keep the plague of body-lice within moderate limits. It does not, however, eradicate it. Various schemes of spraying and fumigating the dug-outs have been tried, in addition, and this with varying success. A grave source of continued infection has been discovered in the overclothing, the lice haunting the seams of tunic and trousers. Methods have been employed of spreading vermigel and. other disinfecting preparations along the seams, but these are messy and dirt-collecting. On general principles, the cleanest and most direct method for the destruction of both the parasites and their eggs should be by heat; but it is remarkable how long it has taken for the proper application of that heat to be generally recognized. What may be termed the official method at the beginning of the war was by that, in most respects, excellent instrument, the Thresh disinfector, a sterilizing chamber mounted on a truck, with an engine that, according to need, supplies steam for propulsion or for superheating the chamber. But for practical purposes the chamber is too small; it cannot deal with the clothing with sufficient rapidity. If packed full of clothing, the heat penetrates but slowly, necessitating hours for sure destruction of the vermin. This is out of the question. 


\section{WAR STORY OF THE C.A.M.C.}

Some years ago (1902-3) the Sanitary Adviser to the D.M.S. Canadians and Colonel Hodgetts had to deal with an epidemic of small-pox at Sudbury, Ontario, and had to disinfect clothing and bedding. on a large scale, with apparatus developed upon the spot. It was then that Dr. Amyot, expanding the suggestion of Dr. Hodgetts and employing two neighbouring wooden sheds and a portable steam engine, produced what it is right to speak of as the Amyot disinfector. The principle is very simple: a chamber is built or selected sufficiently large to permit the outer clothing of from fifty to one hundred men to be hung in it. Round the walls circulate steam pipes, whereby the temperature of the air and clothing is brought up to seventy or eighty degrees; when this has been accomplished, steam under pressure is sprayed from pipes running along the ceiling, and the clothes are subjected to its action for fifteen to twenty minutes. Then it is turned off, and in five minutes the door is opened and the clothes removed in a perfectly dry condition ready for use. Experimental tests have shown that by this means the lice and their eggs are completely destroyed. The essential features of the process, it will be seen, are (I) free access of the steam to each individual article of clothing; (2) the preliminary heating of the clothes so that the steam does not deposit as moisture; and (3) rapidity of action. By this means men can be given their baths in batches of fifty or one hundred, give up their overclothes on entrance and receive the same prior to their departure. The disinfecting chamber is in duplicate, so that one can be filled while the other is working, thus saving delay. The engine of a portable Thresh disinfector, or a loco- 
motive engine, may be employed to generate the steam.*

These Amyot disinfecting chambers proved so useful in the Ist Division that each succeeding Canadian Division had adopted them, and they came into extensive use also along the British front. $\dagger$

Prior to the arrival of that and Division, there had been a considerable amount of trouble regarding the quality of the drafts sent over from England to reinforce the depleted ranks of the battalions of

* The Australian Division has still further simplified the process by taking a box car-the regulation Continental freight car, with its familiar label, "For eight horses or forty men," with its door in the middle on either side, partitioning off the two ends, leaving a passage from door to door, furnishing each chamber with the two orders of steam pipes after the Amyot method, and employing the locomotive to afford the steam.

$\dagger$ As I may have no special occasion to revert to this subject in a later volume, I may here note that a fuller study of pediculosis demonstrates that both the louse and nit are destroyed by a temperature of $5 \mathrm{I}^{\circ} \mathrm{C}$., and, what is more, that dry heat affects them more rapidly at this temperature than does moist (Nuttall).

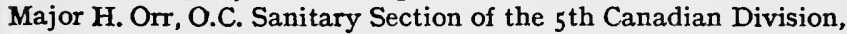
has applied this knowledge for the production of a still simpler and more economical "Disinfestor," in which a brazier filled with live coke, sunk in the floor of a fair-sized chamber, raises the temperature of that chamber to $65^{\circ} \mathrm{C}$., and a simple fan of the Punkha type circulates the air so that the temperature becomes uniform throughout the chamber, two small windows being inserted at high and low level respectively, through which the thermometer can be read. The clothes are hung on rails in this room, and ten minutes after the temperature has risen to $65^{\circ}$ they can be removed completely free from living parasites or living eggs. As with Colonel Amyot's device, the chamber can be duplicated for rapid use, and, as Major Orr points out, in emergency a closed tent will afford all that is needed. This is an expansion of the old-established country method of placing infested clothing in an oven from which the fire has been withdrawn. It has the advantage that boots and leather articles are unharmed. "Orr's huts" are now used throughout the B.F.F. 


\section{WAR STORY OF THE C.A.M.C.}

the Ist Division. It is, let me say, only natural that the "old guard " should look down upon the newcomers, with their lamentable ignorance of the finer points of trench warfare and discipline, their obvious softness as compared with themselves, hardened by months of life in the open and of marching and counter-marching, and that those in command, when they see the newcomers falling behind and straggling raggedly at the tail of the battalion, should, in very pride for the good name of their regiment, complain bitterly of the trash which the authorities overseas have seen fit to send them. The newcomers have to undergo travail and heavy labour before they reach the standard of those who have borne the burden for months at the front. Then, too, under the system adopted, it may be of necessity, by the late Minister of Militia, men were not enlisted in Canada or transferred to England into Reserve Battalions of those already at the front, but were drafted out of another set of battalions which had been left behind in England when the Ist Division was sent over the Channel. Not merely were the men composing these drafts lacking largely in esprit de corps and unfamiliar with the traditions already established of the battalions into which they were drafted, but from the very fact that their original battalions had been left behind when the others went forward, they had been for some months in surroundings which did not make for high martial spirit. For many reasons, therefore, the authorities at the base had to be prepared for unfavourable criticism of the reinforcements they sent over. Apparently, however, there was more than this. Judging from the considerable number of men who, upon medical 
examination at the front, were found unfit and returned to the base, it seems evident that not a few who should not have been passed into the Service had managed to become enlisted in Canada. In our next volume we shall have to enter more fully into this matter. 


\section{CHAPTER XII}

HOSPITAL UNITS AND THEIR ESTABLISHMENT IN FRANCE : THE GENERAL HOSPITALS

Thus far we have accompanied the Divisions, and doing this, save for a reference to No. I Casualty Clearing Station, just behind the front, have made no reference to the Hospitals on the Lines of Communication, to the Canadian Stationary and General Hospitals on the French seaboard, nor again to the Base Hospitals proper in England. This silence has not been due to any lack of recognition of the importance of these units, but to the fact that their history forms a separate story. Undoubtedly, from a soldiering point of view, the officer who goes to the Front, whether as a Regimental Medical Officer or attached to a Field Ambulance or Sanitary Section, is apt to receive greater recognition; nay, let us admit that, taking his life in his hand, he deserves greater recognition than he who, miles behind the line, works away, however busily, in the security of a well-appointed hospital. Nevertheless, if the spirit animating men of the two groups-those at the front and those behind-be taken into account, most often it will be found that there is no difference, that the good soldier works with as stout a heart in hospital as in the field. Pure chance, it may be, determined whether the 


\section{THE HOSPITAL UNITS}

practitioner became enrolled in a Hospital unit or a Field Ambulance. In one city the former was raised, and the medical man volunteered to join it, thus becoming stamped as being a Hospital man; in another city a Field Ambulance, and joining this he went to the Front. Or, again, from the very first, from his recognized position as a practising surgeon, or physician, or specialist, a man has realized that his first duty lay in taking up the work in which his training would render him of greatest service. Such men, whether in Hospital, or chained month after month and year after year in London offices, at Shorncliffe or at Witley, may be, nay, many of them are, eating out their hearts with longing to be at the Front and in the thick of it. England and the French shore abound with Canadian officers of this type. Their part in this war is not with them a matter of valour, but of sheer duty and loyal service. There is for them no greater bitterness than to be grouped, whether explicitly or implicitly, with those who out of precaution choose the hinder post. Thank God! in the Canadian Medical Service the latter are few and far between. Hence, if in this volume the Hospital units are relegated to the end, and if the administrative staff in England is left over for a later volume, it is not that they are held, or are to be held, in less esteem or less worthy of consideration.

General and Stationary Hospitals and Casualty Clearing Stations are no part of an Army Division; they constitute Lines of Communication units, and as such might have proceeded overseas to France so soon as their equipment was complete. It will be remembered, however, that the First Contingent reached England at a very critical period, just 


\section{WAR STORY OF THE C.A.M.C.}

after the First Battle of Ypres. Hospitals were, it is true, needed overseas, more Hospitals to serve the Flanders front, where the casualties had been, and continued to be, very heavy. But how long would the British be able to retain that Flanders front ? Another push like the last, and the Germans might burst through, seize Calais and Boulogne, and overcome the whole north of France. Already, before the Contingent's arrival at Plymouth, the British base, as a precautionary measure, had been transferred from Havre to the Bay of Biscay. Some British Hospitals had been established at the mouth of the Loire, at Orleans and other points in France well to the south of our line. But this meant a painfully long and tedious crosscountry run for the Ambulance trains and their wounded. It was this uncertainty about the future, this difficulty in deciding as to locations, that explains why the Hospital units in general did not go to France before March.

The British authorities contented themselves with asking for one Canadian Stationary Hospital to be placed at the disposal of the Royal Army Medical Service. No. I Stationary at the time had been transferred to London, to take charge of and inaugurate the St. Vincent's Hospital at Hampstead. This explains why its mate, No. 2, was selected, and this unit therefore proceeded to France within three weeks of its landing in England. Alone of the C.A.M.C., the personnel of this one unit and the Nursing Sisters who accompanied it are, as a consequence, included in the "original British Expeditionary Force" and are qualified to receive the " I9r4 Star."

I say " the Nursing Sisters who accompanied 


\section{THE HOSPITAL UNITS}

it," not the Nursing Sisters " of." When the Contingent left Canada no Nursing Sisters were included upon the establishment of a Stationary Hospital. All the Nursing Sisters who came over with the First Contingent were attached to the two General Hospitals. During October, I9I4, it was realized that nurses were as necessary in the smaller as in the larger Hospital units, just as in lesser numbers they were for Casualty Clearing Stations. The forty-five Nursing Sisters who accompanied No. 2 Stationary Hospital to France were thus drawn from the personnel of No. I and No. 2 Canadian General Hospitals.

The unit had responded so promptly that when it arrived in France the authorities there were not ready to locate it. Thus some three weeks were spent, partly at Havre, partly in Boulogne, before the unit found itself established in the Golf Hotel at Le Touquet. It was three months before the next unit, No. 2 General Hospital, crossed to France. But towards the end of November, I9I4, Colonel Bridges, O.C., and a party of officers belonging to No. 2 Canadian General Hospital, accompanied the D.M.S. Canadians to France. General Wodehouse was then in charge of the Medical Services of the Expeditionary Forces, although very soon Sir Arthur Sloggett, D.G.M.S., arrived and opened up quarters at G.H.Q. The D.M.S. proceeded to G.H.Q. and was courteously shown the work of the Casualty Clearing Stations, Field Ambulances and Regimental Medical Services in the Field. For some weeks Colonel Bridges studied the Hospitals at Havre and Boulogne, where he proceeded with the other officers, who now became attached for duty to several British Hospitals in the Bou- 


\section{WAR STORY OF THE C.A.M.C.}

logne area, remaining there until their own unit arrived in France and was fairly well established further down the coast.

Until the departure from Salisbury Plain, the Hospital units, as being of the Ist Canadian Contingent, had been under the one administration. So soon as they crossed overseas they parted company with the Ist Division. That went to the Front, under the medical control of the A.D.M.S. Ist Canadian Division; they became Lines of Communication units, and as such under the D.M.S. Lines of Communication, and more immediately under the (Imperial) A.D.M.S. of the area in which they found themselves. All medical formations overseas are, it is true, under the Imperial authorities, under the Commander-in-Chief, but by this procedure the Hospital units came thus more directly under the British authorities than did, for example, the Field Ambulances and Sanitary Sections.

As we are describing the happenings of three years ago, and as with scarce an exception the units have since then been moved to other areas, it is permissible to indicate the localities of the Canadian Hospital units in I9I5.

For orderly treatment it will be better to trace in regular sequence the fortunes of the General and Stationary Hospitals, the Mobile Laboratory and Depôts of Medical Stores. A little difficulty arises with regard to the presentation of these Hospital matters, in that certain units, like Nos. 3 and 4 General Hospitals, which may be regarded as part of the Second Contingent, were sent overseas within a few days of their arrival in England, and thus set to work within a very short time after the"General 


\section{THE HOSPITAL UNITS}

and Stationary Hospitals of the First Contingent had become established in France. These later Hospitals presented many novel points, and after full consideration it is thought better to detail their history in the next volume. For convenience the story of each of these units will be carried to the end of the year I9I5.

\section{No. I Canadian General Hospital}

This unit, with its thirty Officers, seventy Nursing Sisters and two hundred odd of other ranks, reached the site set apart for it a little distance outside Etaples on May I7th, IgI5, and on the Igth had tents up and beds ready for one hundred patients.

Etaples, the Portus of the Romans, the Quentawic or plain "Wic" of the Franks, the "Eatables" of the British Tommy, was before the war a very fishy fishing village, as sluggish as the little Canche which, wandering through the marshes, formed its harbour and gave it its raison d'être. But with the old church of St. Michael, old water front, its fishing boats, the marshes and grazing cattle, it was beloved of artists.

It has a notable history associating it with Julius Cæsar, St. Boniface, Charlemagne, Louis XI., Francis I., in fact with all the more select figures in French history up to and including the great Napoleon. Its position is such that it was the great and flourishing port for trade with England in the early medieval period; its rise and decline are curiously parallel with those of the Cinque Ports over against it on the Kentish coast, with which the men of the C.E.F. have become so well acquainted. As might be expected, it was duly looted by the 


\section{WAR STORY OF THE C.A.M.C.}

Normans and English; by the last just after the Battle of Crécy.

The Hospital was given ground which the patriotic Frenchman holds as almost sacred. Here it was that Julius Cæsar collected his troops for the invasion of Britain in B.C. 55. Indeed, according to the learned Père Le Sueur, curé of the neighbouring village of Camiers, the Hospital occupied the site of the old burial ground of Cæsar's Tenth Legion. Here, too, it was that in 1804 Napoleon collected and reviewed the troops destined for the invasion of England, the flotilla of four hundred flat-bottomed boats to convey them being collected, secure against observation from the high seas, in the estuary of the Canche.

Thus it was that France gave over to Canadian use ground of her most historic, and here in the plain between the dunes and the sea a village of tents sprang up, ready, if need be, to receive patients within three days, although a week elapsed before the nursing sisters were all assembled, and a fortnight before the D.M.S. Lines of Communication, Colonel Wodehouse, inspected it, and the first convoy of fifty-one patients was admitted. On its staff was a collection of well-known Canadian medical men. The Commandant, Colonel Murray MacLaren,* a leading physician in New Brunswick, was at the opening of the war President of the Canadian Medical Association. The annual meeting of that Association at St. John had concluded scarce three weeks when war was declared. The head of the medical section, Lieutenant-Colonel F. G. Finley, $\dagger$

* C.M.G. ; later D.D.M.S. at Canadian Medical Headquarters in London; now O.C. Granville Canadian Special Hospital.

$\uparrow$ Now Colonel and C.B. ; on the Canadian Consultant Staff in London until recalled to Canada, October, 1918. 


\section{THE HOSPITAL UNITS}

was a leading physician of Montreal, a Professor of Medicine and Clinical Medicine in McGill University, just as the head of the surgical section, LieutenantColonel Kenneth Cameron,* Surgeon to the Montreal General Hospital, was on the surgical staff of that University. The officers and personnel were, in fact, mainly from Montreal and Eastern Canada, the nucleus of the unit being the $5^{\text {th }}$ (Montreal) Field Ambulance brought to Valcartier by Major R. P. Campbell. $\dagger$

It began as a tent Hospital, provided with Indian pattern hospital tents, spacious and comfortable in the summer weather. By placing these end to end in series of eleven, five on either side of a central service tent, spacious and roomy wards resulted, the beds being ranged half along one side, half along the other, each lateral ward holding thirty-two beds. In comfort and spaciousness these were a great improvement upon the official Canadian Hubert tent with which the unit was originally supplied. These only housed six beds, and that uncomfortably, four on one side, reaching almost to the tent poles, and two on the other lengthwise, affording but a narrow passage-way. Substantial and well-built as were the Hubert tents, it was soon discovered that they were designed for Canadian conditions and not European : the side walls of the outer tenting did not reach the ground by many inches. This is a convenience in summer as helping to keep the tents cool, but a decided inconvenience in the winter when warmth is a first consideration.

* C.M.G. ; later O.C. No. 2 Canadian General Hospital, and A.D.M.S. Bramshott.

$\uparrow$ Later Lieut.-Colonel, O.C. No. 6 Field Ambulance; this distinguished surgeon and brilliant soldier was killed in action. 


\section{WAR STORY OF THE C.A.M.C.}

In Canada snow can be piled up around the tent, and the outer tenting tucked into this. Flanders mud, or French sand, are not precisely ideal substitutes during the winter rains.

Nevertheless, the Indian Hospital tents had also their disadvantages. The first to make itself evident was the difficulty in creating a water-tight junction between the tents in series. Heavy rain storms were not infrequent, and the rain naturally poured down the sloping ends of the tents and used the junction as a gutter. No perfect method was elaborated to counteract the leakage. Then, too, the cotton ropes with which the tents were provided did not take kindly to wet weather, swelling and shortening, dragging out their pegs, and needing constant supervision. And as the months progressed and winter approached the canvas made for the Tropics showed itself not stout enough for the gusty weather of the French coast. It became obvious that, healthy and admirable as are tents for hospital purposes in summer, they are, if not impossible, at least unadapted for winter conditions in northern France. One after another at the British Hospitals the tents were replaced by hutments.

Thanks to the energy of the O.C. and the generosity of his friends in St. John, N.B., what was the finest and most attractive of these hutments along the French coast was provided at No. I, in the spacious "New Brunswick" hut, completed on November 3oth, rgr5.

"7.I5 p.m. The Company paraded in front of the hut with the Nursing Sisters grouped in the anteroom, to receive General Alderson and Colonel Graham Thompson, C.B. There were also present Colonel Carr, A.D.M.S. Etaples area, Colonel Foster, 


\section{THE HOSPITAL UNITS}

D.D.M.S. Canadian Corps, Colonel Sir James Clark, Lieutenant-Colonel W. T. Christie, A.A. and Q.M.G., E.A.D., Lieutenant-Colonel A. MacDonnell, Lieutenant-Colonel R. P. Campbell, Major Cooper, R.E., Captain Towse, Captain Stuart Gordon, and other officers. On behalf of the patriotic citizens of New Brunswick who had supplied the funds for the building of the hut, authority having been given by the I.Q.C., General Alderson stated that the building was now ready for the reception of the sick and wounded, and asked Colonel Thompson (O.C. Etaples area) to take the hut over and declare it open. In doing so he spoke very highly of the work done by the C.A.M.C. in France. Colonel Thompson accepted the building, declared it open, and expressed his approval of the facilities afforded in the wards. The building was then inspected by the company present."

We quote this in its entirety, since ceremonies of this nature are as infrequent overseas as are official banquets. Colonel Murray MacLaren, as a loyal Scot, had chosen St. Andrew's Day for the ceremony, and the glories of the St. Andrew's Day dinner which followed, at which all the above visitors were present as guests, with yet others, are still remembered and talked about by the beati participantes.*

* The cost of this first New Brunswick hut was $£ 994$ 9s. 9d., and was provided by a free-will offering, unsolicited, from the friends of the O.C. That offering was in the neighbourhood of $\$ 10, \infty 00$, and the surplus permitted the subsequent erection of an Admission and Discharge hut in August, 1916. at a cost of $t 4786$ s. 8d., and in June, 1917, of a second New Brunswick hut ("N Ward "), largely used for fracture cases, at a cost of E704 I9s. This last is 160 feet long by 20 feet broad, with Sisters' room, scullery, lavatory and room for special cases.See Sem Weekly Telegraph, St. John, N.B., November 3rd, 1917. 


\section{WAR STORY OF THE C.A.M.C.}

Two days earlier the fine Durbar tent erected for Church services was used for the first time. It contained a memorial to the late Captain Ingles, the manly chaplain to the unit, who, in the course of his duties at Salisbury Plain, had contracted and had succumbed to cerebro-spinal fever. This was in the form of a portable oak altar, with Bible, vases and frontal for the lectern, presented by his father, the Very Reverend Archdeacon Ingles, of Toronto.

But this first winter in France the "New Brunswick" and the administrative block were the only hutments. Save for these, through gales and frost, No. I somehow pulled through the autumn and winter of $1915-16$ in tents, the officers and nursing sisters having Alwyn huts, i.e., small detached cubical apartments of light wooden framework, each some twelve by ten feet, over which canvas is stretched, with wooden floors and windows of celluloid-and a stove. These are more comfortable than the description implies : in fact they were retained after the patients were transferred to hutments.

And so, from May 3Ist, when the first patient, a B.C. man of the $4^{\text {th }}$ Canadian Battalion, was admitted, the Hospital was in full working order, and busy.

From May 3Ist to December 3Ist, I9I5, there were ro,62I admissions, a daily average of close upon fifty, although, as can be readily understood, the number varied greatly from day to day. Thus the War Diary notes that July gth was a very busy day, with I35 admissions and II7 evacuations. Another very busy season was at the time of the September offensive, when, subsidiary to the great French effort in Champagne, there was great activity along 


\section{THE HOSPITAL UNITS}

the British front, culminating in the battle and capture of Hooge. As the O.C. says in his War Diary: "The good news of our successes on the Western Front has so cheered everyone that no one seems to mind how hard he works." For that good work and "for the prompt and thorough manner displayed by them in the reception and evacuation of wounded," the A.D.M.S. Etaples area expressed his appreciation to the Staff of No. I Canadian General in Orders (27.9.15). In that week, or more exactly from September 26th to the 29th inclusive, 156 operations were performed under anæsthesia. On the 27 th alone there were 73 .

At such periods the strain on all the personnel is very heavy. An establishment of 235 officers, N.C.O.'s and men may seem large, even for a Hospital of over one thousand beds. As a matter of fact there is in it very little margin. It is sufficient for routine work, but when there is a succession of large evacuations and large admissions, and when bearer parties have to be found at all hours, a very different condition exists. During a "push " Ambulance trains arrive at any hour day and night ; not infrequently they arrive late, an hour or more after their arrival has been advised, and if any considerable proportion of the personnel-a dozen or more-be laid up, it is only the good spirit of the remainder that keeps the ball rolling.

One is apt to regard a General Hospital as a very stable unit, yet reading over the records of this first year in France, it is impossible not to be impressed with the constant flux.

At Salisbury Plain, Lieutenant-Colonel Vaux left the unit to become A.D.M.S. at Tidworth, returning in May, and in January Major R. P. Campbell was 


\section{WAR STORY OF THE C.A.M.C.}

called to Canada to assume command of No. 6 Canadian Field Ambulance, while the two pathologists of the unit, Major Rankin and Captain Ellis, were detached in March, along with four assistants and two batmen, to form No. 5 Canadian Mobile Laboratory, which, with Lieutenant-Colonel Nasmith, did excellent work behind the front. The unit was scarce established in France when Colonel C. Wylde and Major Doherty were recalled to London to be appointed A.D.M.S.'s on the staff of Surgeon-General Jones, D.M.S., being given charge of personnel and stores respectively. In August, Major E. A. Le Bel, who had been seriously ill, left on sick leave and did not return. After convalescence he became attached to the French Canadian Medical Unit as second in command (becoming later O.C.). This eventually became No. 8 General Hospital on the outskirts of Paris. In October, Major E. R. Brown and Captain J, F. Creighton left for work with the Ist and 2nd Canadian Divisions respectively. In December, Captain W. $\mathrm{J}$. Herringer was transferred to the and Canadian Reserve Park, Captain A. B. Chapman to the Ist Division, Captain W. H. Eager to England for duty, and Captain T. L. Butters to the 2nd Division, while Major Mackenzie Forbes, having received orders to proceed to Canada, was struck off the strength.

To replace these there were at various periods corresponding attachments to the unit: Captain G. C. Draeseke, Major L. R. Brown, Captains W. A. Burgess, W. P. Walker, F. C. Bell, C. P. Howlett, G. Musson, W. H. Eager, W. H. Scott, J. J. Ower, W. L. Maclean, L. G. Hodder, C. L. Cock, and F. A. C. Scrimger, V.C., along with Honorary 


\section{THE HOSPITAL UNITS}

Lieutenant and Quartermaster W. McLeod Moore. These lists give some idea of the fluctuating condition of a General Hospital Staff.

\section{No. 2 Canadian General Hospital}

In Chapter III. has been described how, by a wholly innocent error committed in the dead of night, No. 2 was deprived of its right of berth on Salisbury Plain.- As a result there ensued a period of dismemberment. While a small nucleus under the O.C., Lieutenant-Colonel Bridges, P.A.M.C., as it were to preserve its face, was given charge of a Hospital of some thirty beds at Lavington Manor, the majority of the personnel were temporarily attached to one or other of the hospital sections conducted by No. I General Hospital, while officers were temporarily transferred here and there, some becoming attached to No. I, while in November a baker's dozen accompanied the O.C. to France just too late to receive the I9I4 Star, LieutenantColonel Bridges to study for a short time the workings of General Hospitals already established there, the rest to be attached to British Hospitals in the Boulogne area, until in March the unit was reassembled and established at Le Tréport.

Like Etaples, Le Tréport has a history, and one associated with England, for it was in the old church of the town that William the Conqueror was married. It is a cheerful little seaport town, situated in a cleft of the chalk rampart which here forms the coast, a cleft through which the river Bresle has eaten its way to the sea. Prior to the war, it had been a popular French watering-place, beloved of the Parisian, and the fashionable, or 


\section{WAR STORY OF THE C.A.M.C.}

hotel, boarding house, and casino area was crushed in narrow streets between the chalk cliffs and the sea, the old town stretching inland along either side of the harbour basin. So popular was it, and in consequence so crushed, that shortly before the war plans had been made for the establishment of a new town on the plateau on the top of the cliffs to the south of the harbour, some hundreds of feet above the town proper. A funicular or inclined railway, such as Canadians are familiar with at Quebec and on Mount Royal at Montreal, had been in operation for some little time, and a large up-to-date hotel, built, rumour said, by German capital, dominated the town at the edge of the plateau. It had just been completed, and made an excellent hospital for British officers. It was close to this that No. 2 was located, on land already marked out into avenues, round points, and radiating and curving roadways, according to approved city planning and prospective town site devices, so that to Western Canadians more especially the ground had quite a homely aspect. The unit shared the camp ground with No. I6 British General Hospital.

It was on the I4th March early in the morning that the unit arrived at Havre, and, getting the right tide, docked at 9 a.m. and began unloading. Within thirty-six hours the equipment had been loaded on fifty-seven cars, a most creditable performance that received commendation. The Commandant and A.D.M.S. Havre, offered to supply any deficiencies of kit, but found the unit complete. At 3 a.m. on the r6th, one train left Havre, another five hours later. Two days were spent unloading and moving the equipment up the hill to the camp 


\section{THE HOSPITAL UNITS}

ground, and then followed a busy week of tent pitching. On the Igth, the matron and fifty-seven nursing sisters reported; on the 27 th, the thirteen officers who had been working in British hospitals in France rejoined the unit. On the 3Ist, the hospital furnishing was complete and the unit ready to receive five hundred patients. On the 8th April the first admission of twenty wounded took place.

The Indian tents were joined together in threes to make wards for twenty patients, and in the frequent rains the junctions were found to leak badly.

By the middle of the month there were two hundred patients in hospital. On the 2oth a new operating-room was opened up. On the 24th, rumours reached the hospital of heavy fighting at Ypres, and all arrangements were made to receive large convoys. The first of these, I64 cases, arrived at II p.m. on the 25th, followed by eighty-five at eight the next morning, and ninety-nine more wounded at six in the evening; altogether 348 in nineteen hours. Everything worked smoothly, but at midnight on the 26th many departments were still busy, there being a number of urgent operations.

The unit was brought up to full strength at the end of April by the arrival of nine officers and eighty men. But scarcely had it been completed when it was deprived of two of its leading officers.

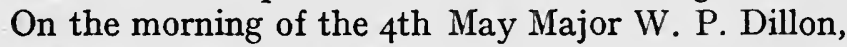
a leading member of the surgical staff, slipped and fell when attempting a short cut down the steep incline leading from the plateau to the lower town. Falling some twenty feet, he was picked up un- 


\section{WAR STORY OF THE C.A.M.C.}

conscious, with symptoms of fracture of the base, and despite operation he died in the course of a few hours.* Another,senior member of the staff, Major R. L. Gardner, was thrown from his horse, and on the IIth May was transferred to England with synovitis of the knee. This incapacitated him for so long a period that he did not rejoin, but was eventually invalided to Canada, there undertaking work in Ottawa.

A second rush of patients came upon the I8th May (the Festubert engagement), when 537 patients were admitted before breakfast, making over a thousand in hospital-r25 were evacuated. While the convoys for admission detrained at Le Tréport, men for discharge to "Blighty" were taken by the motor ambulances to Dieppe, some ten miles distant. Here was no case of patients being brought by the train directly into the hospital grounds as at No. I. It necessitated the existence of a motor ambulance unit of some twenty cars.

On the 22nd was another convoy of IIo, including forty-eight Canadians, many very badly wounded, but all cheerful, together with three German prisoners who were segregated in order to be watched for typhus, which was said to be present among the German troops. Two days later 160 were admitted, mostly Canadians, who told of continual successes in spite of the terrible hammering by the German artillery.

On the 29th May there was a convoy of 201 patients admitted at II p.m. All were admitted smoothly and without confusion. By now the procedure in the admission tent had been developed

* Major Dillon had been a member of the staff of No 2 C.G.H. from its first days at Valcartier. 


\section{THE HOSPITAL UNITS}

whereby admissions were conducted with the greatest promptness. As this method was first adopted at No. 2 and was subsequently adopted at all Canadian General Hospitals, it deserves description.

The British Army Regulations demand that on admission the name and other necessary particulars regarding the patient be entered into the Admission and Discharge Book. This "A. and D. Book" is the old-established basis of all British military hospital records. It is, or was, the one official record of the patient's stay in hospital, the basis of all military hospital statistics, the official evidence of the length of stay of the individual patient in hospital, of the diagnosis of the case, of the disposal of the patient. According to Regulations, the admissions for the day should be entered in sequence in one book. It can be pictured what delay would occur when a convoy of fifty to a hundred patients reaches the hospital in the middle of the night, were each in his turn to wait for the particulars to be written down in the one book before passing to the wards, or, again, what a task would be thrown upon the Registrar were he to admit the patients haphazard, without entry, and then proceed round the various wards to enter the particulars regarding each newcomer in the $\mathrm{A}$ and D. book which he carried with him.

With the approval of his O.C., Major T. J. Clarke,* P.A.M.C., the Registrar, had printed locally an index card, six by four inches, giving the data

* Now Colonel. Later O.C. No. I Canadian Stationary Hospital and O.C. Granville Canadian Special Hospital; lately appointed A.D.M.S. to the Canadian Expeditionary Force to Siberia. 


\section{WAR STORY OF THE C.A.M.C.}

demanded in the A. and D book, and with space on the back for an epitome of the clinical history and other remarks.

As the stretchers with patients, or the walking wounded, enter the admission tent, they are directed in order to one of four tables. At each is stationed a Sergeant with two orderlies. The Sergeant obtains the necessary particulars from the man when he can speak, or, if too ill to speak, from the card with which he had been tagged at the Dressing Station or Casualty Clearing Station-

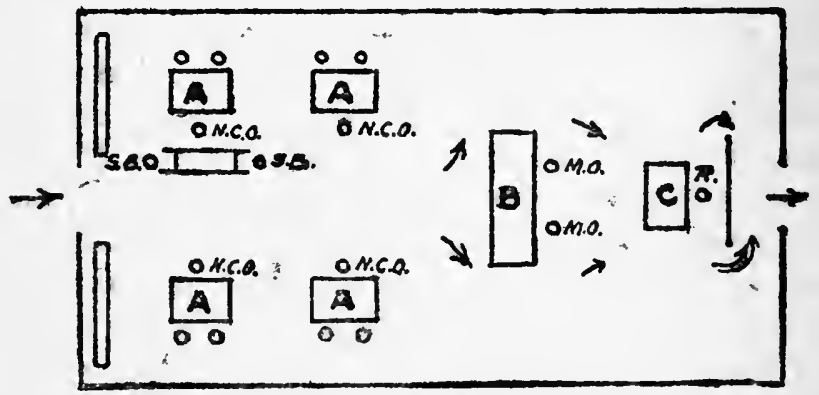

A. and D. Tent arranged for the admission of a convoy.

A.A. Tables for entry of personal details.

B. Diagnosis table. C. Registrar's and allotment table.

regimental number, name, age, unit, religion, and so on-and as each answer is obtained, he dictates it to the two orderlies. One inserts the particulars on the Hospital card, destined for the Registrar's Office, the other upon the Diet Sheet which accompanies the patient to the ward. These two documents accompany the patient to the diagnosis table, B, where are two or more Medical Officers, who make the provisional diagnosis which determines whether the patient is to be treated as a medical, surgical or special case. So soon as this 


\section{THE HOSPITAL UNITS}

has been made and entered on the documents, the patient passes to the final table, $\mathrm{C}$, that of the Registrar, who has before him a plan or list of beds vacant in the different wards, and promptly assigns him to his particular bed in a particular ward. The Hospital card is left here, the Diet Sheet accompanies the man to the ward. Without delay the man is carried or led to the ward. There he finds waiting in a bundle pyjamas, dressinggown, and all necessary belongings. Whenever possible, the next phase is that these are carried by him to the bath. There the Service clothes are left, and, clean and in hospital attire, the man is ready to enjoy his rest between sheets. Stretcher cases are without delay undressed by orderlies and put to bed.

The Registrar collects the Hospital cards, and first enters them in alphabetical order in the A. and D. book, then distributes them into a series of pigeon-holes, one for each ward. When men are listed for discharge, their cards are removed from the pigeon-holes and sorted in alphabetical order in the "Discharged" case.

By this simple system at any given moment the number of patients in any given ward can be determined, and the number of beds vacant, the location of patients in hospital, and all the essential particulars regarding any discharged man. Inquiries reach the Registrar's Office by the score every day regarding present and past patients. Under the old system this demanded an interminable search through the A. and D. books, with their haphazard entries. Now all the necessary particulars are at hand in a minute. By this system men can be admitted with a business-like expedition that is 


\section{WAR STORY OF THE C.A.M.C.}

a delight to see. The O.C. records, under date 18.6.15, "Took in convoy of 236 in record time of fifty-five minutes." And again on Ist August, "Took in a convoy of 263 just after midnight, registering the whole lot, giving them all soup, and getting them all in bed in one hour and ten minutes."

We have given this detail, since the Hospital card, although unofficial, was rapidly adopted in all Canadian hospitals in France, being found indispensable. It showed itself of such proved utility that after a year it was adopted and made official by the British authorities there, although mistakenly, if we may venture to criticize, the instruction was given that it was to accompany the man to the wards, thereby depriving it of its greatest utility, that, namely, of aiding the Registrar in the compilation of his abundant returns re patients, admissions and evacuations. As used in the wards it becomes a Medical History Sheet in brief.

On August 5th occurs the record: "Began to move our tents preparatory to the erection of winter huts. It is a difficult undertaking as we are very busy in Hospital." Yet at Le Tréport the move was very necessary. Situated on a plateau at the top of the sea cliff, it would be difficult to imagine a more windy site than is that of No. 2 during the winter months. Already in July there had been heavy winds and rain storms, and twice during the month tents had been blown down. But despite these preparations, a fortnight later no hutments had been started, the contractors being very tardy. By night on September 3rd, the wind had become so strong that a great many tents went down in spite of the men working all night 


\section{THE HOSPITAL UNITS}

to try to keep them up. "The ropes have become rotten and kept breaking in all directions." On the following day there is the same story: "Wind and rain all day. All ranks worked to save canvas, but while some were being replaced with great difficulty, other rows would break loose and go down. We are in a great mess, but rapidly getting straightened out." From now on, the building of hutments proceeded with more dispatch, so that on September $25^{\text {th }}$ Lieutenant-Colonel Bridges reports with some confidence: "Orders received to increase accommodation by fifty per cent. This was easily arranged, as we had already drawn the extra bedding, and sufficient huts are far enough advanced to furnish good shelter. All our original tent accommodation is still standing, though much of it has been removed to new sites to permit the building of huts."

27.9.I5. "Sixty-eight more cases sent to England. News arrives of very substantial British advances at Loos and Hulluch, with the usual large number of casualties. Took in another convoy of 338, nearly all serious cases." 29.9.I5. "Weather turned to gales with rain, and our canvas is under very heavy strain. A few tents have gone down. One ward had to be evacuated. Another convoy of 306 stretcher cases landed in on us at II a.m. Some of these we had to put on mattresses on the floors of the new huts. The weather is too bad for Hospital ship to cross, so we cannot get rid of any. Our accommodation will soon be all gone. We have now 1,306 , and hardly a slight case in the lot. It was a hard day's work for all ranks in the wind and rain and mud, but all dressings had been done by about Io p.m. Besides dressings, we did thirty-six major operations 


\section{WAR STORY OF THE C.A.M.C.}

in the operating-rooms. Three tables were running most of the day. The weather moderated at end of September."

The storms, however, began again in November. The War Diary of the O.C. on November 13th records : " Gales all last night, and about five o'clock in the morning they developed into a regular hurricane which tore large numbers of tents into ribbons, the rain soaking the equipment. The patients were crowded into the few available huts. The fine weather of last month was wasted by the contractor in doing practically nothing with our huts, and now the weather is so bad he cannot get his men to work, and our patients and personnel have to suffer. We are compelled to reduce our accommodation to 560 beds-temporarily we hope. The wind is so strong that it carries huge pieces of galvanized iron roofing through the sky like sparrows. Wind moderated toward evening, but it rained practically all night."

Routine Order 298 of Lieutenant-General Sir F. T. Clayton, K.C.M.G., C.B., I.G.C., of November 3rd, ran as follows: "Act of courage. The Inspector-General of Communications wishes to express his appreciation of the prompt and courageous conduct of No. 50973 Private D. McEwen, C.A.M.C., at Le Tréport, on August 29th, 1915. A French soldier had been bathing, and owing to the rough state of the sea was at the point of being drowned when Pte. McEwen dashed into the sea, fully dressed, and succeeded in bringing the unconscious man safely to land."

Otherwise to the end of the year matters progressed uneventfully. By November 2oth the number of admissions since opening up in France 


\section{THE HOSPITAL UNITS}

seven months previously had reached ten thousand, with 1,077 operations performed under anæsthesia, 2,360 X-ray plates taken, 1,5 Io dental cases, and a percentage of deaths of 0.6 , or so low as threefifths of one per cent., a very remarkable demonstration of the quality of the treatment afforded. 


\section{CHAPTER XIII}

HOSPITAL UNITS : THE STATIONARY HOSPITALS

\section{No. I Canadian Stationary Hospital}

Formed at Valcartier on September I3th, I9r4, by details from various military units, No. I Canadian Stationary Hospital drew its officers and men from all parts of Canada. Its first Commanding Officer, Lieutenant-Colonel Lorne Drum,* P.A.M.C., had been stationed for some years at Headquarters in Ottawa, where he had been D.D.G.M.S. ; the second in command, Major Hanford McKee, was a well known ophthalmologist from Montreal. The other officers hailed from Saskatoon, Sask., Windsor, N.S., Quebec, Halifax, Calgary, Alta., and Pictou County, N.S. There was a similar wide selection exercised in the case of the men, although a fair proportion had belonged either to the Ist or the 4 th Field Ambulance, both Nova Scotia units.

But a short stay of little over three weeks was made at Salisbury Plain, and then the unit was ordered to London to take over what had been the Mount Vernon Hospital for Chest Diseases, ad-

- Now Colonel. Later D.D.M.S. at Headquarters in London and A.D.M.S. 5th Canadian Division; now O.C. No. 3 (McGill) Canadian General Hospital. 


\section{THE STATIONARY HOSPITALS}

mirably situated on the high ground at Hampstead, close to the Heath. There was no idea that any of the base Hospital units should become permanently established in Great Britain, but the taking over and training in the organization and interior economy of a Military Hospital was regarded as a valuable experience. Well built and well appointed, Mount Vernon Hospital had already had a somewhat chequered career. The Medical Research Committee had practically taken it over just before the opening of the war to serve as a Hospital for special cases under observation. Then the War Office stepped in and claimed it for conversion into a Military Hospital, giving it over to the Canadians. To fit it for the new purpose it required extensive equipment, with overhauling of the plumbing and certain structural alterations, provision of an operating-room, etc. These kept the unit fully employed for the next two months, until upon January 28th the Hospital was declared fully equipped and ready for patients. Upon the very next day the unit received orders to proceed overseas ; on the last day of January it embarked for overseas at Southampton, along with No. I Canadian Casualty Clearing Station. Following upon this evacuation by the Canadians there were again, we are informed, negotiations on the part of the Medical Research Committee to utilize the building. Eventually it became famous as the Hampstead Heath Hospital for the study of what is known as "Soldier's Heart," under a group of distinguished consultants, namely Sir William Osler, Bart., Regius Professor of Medicine at Oxford, Sir T. Clifford Allbutt, K.C.B., Regius Professor of Medicine at Cambridge, and Sir James Mackenzie, 


\section{WAR STORY OF THE C.A.M.C.}

the renowned specialist upon heart disease. As such it still retained Canadian affiliations, since two of the leading members of the active staff were Major J. C. Meakins, * C.A.M.C., and Captain T. F. Cotton, C.A.M.C., both of whom had already distinguished themselves by their studies upon cardiac affections. The Hospital buildings eventually proved too small for the number of patients presenting themselves, and now the staff has been transferred to a larger Military Hospital at Colchester, the Mount Vernon building being transformed into an Officers' Hospital for the Royal Flying Corps.

Arrived in France, the unit was encamped for twenty days on the outskirts of Le Havre. At the end of the first fortnight there the O.C., LieutenantColonel Lorne Drum, was called back to London to assume the duties of D.D.M.S., leaving Major S. H. McKee as Acting O.C. Later this appointment was confirmed with promotion of the Major to the rank of Lieutenant-Colonel. Another seventeen days was spent in billets at Boulogne. Only on March I3th, I9I5, were definite orders received to erect a three-hundred bed tent hospital at Wimereux, on the outskirts of Boulogne. In eleven days this was erected, equipped and ready to receive patients, the first convoy arriving on April 3rd. From now on the unit was fully engaged. In the month of May 2,450 patients were admitted with an average of eight operations per diem requiring general anæsthesia. On June 6th came the order to increase the capacity to four hundred

- Previously on the Staff of No. 3 (McGill) Canadian General Hospital, later Lieutenant-Colonel and head of the medical section of No. I5 Canadian General (Duchess of Connaught's Canadian Red Cross) Hospital at Taplow ; now recalled to Canada. 


\section{THE STATIONARY HOSPITALS}

beds, with authority to add four more officers, three sergeants, two corporals, and five men to the personnel.

During the month of June the work became lighter, the cases admitted (635) being of a less serious nature, and towards the end of the month preparations were made to reduce admissions and prepare to move elsewhere. These preparations were suspended on July Ist, when a new German offensive was threatened ; on the 22nd came orders to pack up equipment preparatory to moving to Abbeville; on the 28th, however, a cable was received from the War Office ordering the unit to store its equipment in Bolougne and embark without delay for the Mediterranean. Two days later the personnel embarked for Dover ; in four days from receiving the order the unit found itself on the Hospital Ship Asturias, in the company of two other Canadian Stationary Hospitals, Nos. 3 and 5, which had come overseas from Canada as part of the Second Contingent. The history of these other two will be dealt with in a later volume. They arrived off Malta at dawn on August 8th, to find that no instructions had been received there concerning their future movements. A cable to the War Office, however, received a prompt answer, and before midday orders came to proceed to Alexandria. Their arrival there had also not been advised, but after a day of contradictory orders instructions came to proceed to Lemnos. This necessitated transhipment of the officers, men, and equipment to a transport, the Nursing Sisters being transferred to the Hospital Ship Delta. The change from the well-appointed Asturias to a ship which had been used as a horse transport and had not 


\section{WAR STORY OF THE C.A.M.C.}

since been cleaned, was an introduction to the hardships of the Gallipoli campaign. They sailed from Alexandria at dawn of the day (August I4th) upon which the Royal George-a boat well known to Canadians-was torpedoed, and that in the very seas they were about to cross.

For those who still remembered their Greek dramatists, the glamour that enhaloed the isle of Lemnos, that halting-place in the journey to Troy, was rapidly dissipated. Everything associated with the brave but ill-fated Gallipoli expedition had in it an element of unpreparedness, and was as the untimely fruit of the womb. And this is as true of the medical as of the military arrangements. It is impossible to write an honest history without reference to those six first weeks of the work of the Canadian medical units upon the island, during which the administration was unable to cope with the urgent needs of those units. We freely admit that the situation was most difficult. Conditions which on the Flanders front could be remedied from the base or Great Britain in two or three days, needed in the Levant four to six weeks, and that through seas infested with German and Austrian submarines. Admittedly, also, it was desirable to have Hospital units as near as possible to the war zone, and Lemnos was the nearest island that could be utilized.

But even if in Greek fable the island was famous for its race of Amazons and their Lemnean deeds, it proved itself scarcely a fit place to which to send Nursing Sisters charged with healing and not with extirpating their men-folk. The greater part of the island is mountainous, with fertile valleys, but treeless ; but this healthier part, in the absence of roads and means of transportation, was too far removed 


\section{THE STATIONARY HOSPITALS}

from the one available port, Mudros, to be chosen for Hospital sites. A mile from West Mudros was a wide sandy plain, and this was selected as the place whereon the Hospital units should pitch their tents. Whoever was responsible for the choice, no heed seems to have been taken of the fact that this had been only recently vacated by a camp of some thousands of Egyptian labourers, not possessed of the most elementary ideas of camp sanitation. Nor when No. I arrived at the selected site had any sanitary provisions been taken. This bore

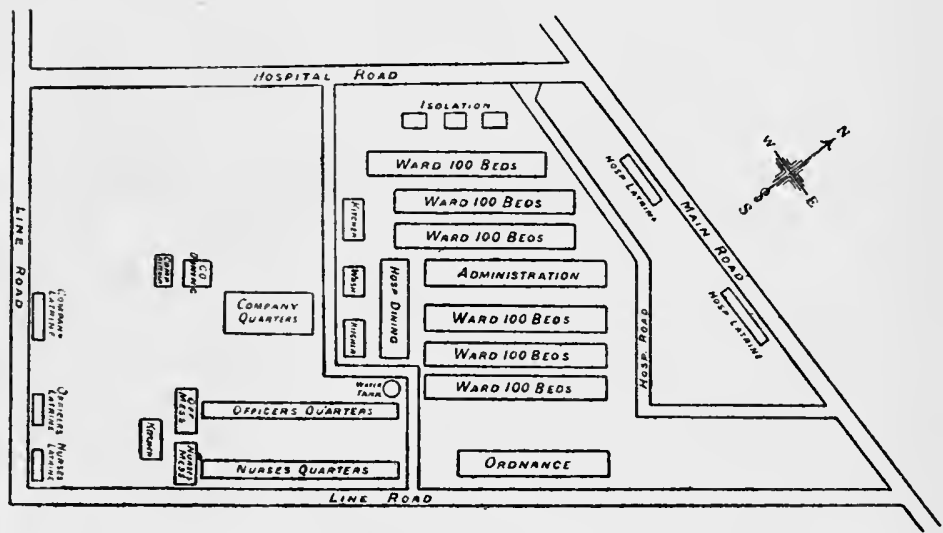

Scole 100 fael lo lineh

with peculiar hardness upon the Nursing Sisters, when, in the course of a few days, they rejoined the unit, on the 23rd. Their quarters also were small, translucent bell tents, two nurses to a tent.

There was no deep water and no wharf at West Mudros, wherefore the equipment had to be taken ashore in lighters. On August Igth the personnel, except the sisters, were at the camp ; on the 20 th the erection of the Hospital was begun, the tents, 


\section{WAR STORY OF THE C.A.M.C.}

Indian pattern hospital marquees, 35 by $I 7$ feet, being joined in sets of six to form wards, each line affording capacity for one hundred beds. Three days later the Nursing Sisters rejoined the unit, and almost simultaneously arrived the first convoy of 125 patients, mostly medical and dysenteric. Five days later there were over five hundred patients in hospital.

Scarcely had the Hospital opened before the members of the personnel began to be brought down with that Egyptian plague, amœbic dysentery.* From the classical period up to the present time a particular earth from Lemnos, the terra sigillata, $\uparrow$ has been renowned for its curative properties; such were not possessed by the contaminated sand of Mudros plain!

From the first there was difficulty in obtaining supplies ; no latrine pails were available ; the water supply was inadequate, and, what is more, there was no water-cart in the equipment. This defect, we learn, was remedied at the expense of a British camp in the neighbourhood, none being obtainable by requisition from ordnance; the food was scanty and of poor quality, and what was particularly serious in a hospital filled with dysenteric patients, there were no supplies at ordnance for sanitary purposes. The main Ordnance Depôt was rendered

* This disease is extraordinarily common in Egypt, and it was Kartulis of Alexandria who first recognized this particular form of dysentery and discovered the causative parasite.

$\uparrow$ So called because it is sold in blocks or cakes, each of which is stamped. It was considered a cure for festering wounds. There is nothing new under the sun! The antiphlogistin of to-day is an adaptation of the terra sigillata in use since the dawn of history. 


\section{THE STATIONARY HOSPITALS}

largely inaєcessible by being upon a ship in the roadway with no regular means of communication. The flies and the dust caused intense discomfort.

When the D.M.S. of the Mediterranean Forces visited the Hospital on September Ist, dysentery was already prevalent among the Officers, Nursing Sisters and personnel. By now six hundred cots were equipped and filled, and the strain on those members of the personnel who were still unaffected was very heavy. There was still but one watercart, and the well was running dry. On September 8th the O.C. records in his War Diary: "Sickness among Officers, Nursing Sisters and men becoming prevalent. Admission to Hospital of dysentery cases increasing daily. The fly menace is very great, also the dust, and poor food supply very trying."

From now on, conditions as regards supplies improved materially, but still only the bare necessities of existence could in general be obtained. The Hospital had reached Mudros with equipment for four hundred patients ; the outbreak of dysentery at Gallipoli was so serious that it was ordered to expand to six hundred beds, and this with the staff itself largely laid up, not with a transient summer diarrhœa but a gravely disabling illness, which should have incapacitated the individual for two or three weeks where it did not permanently invalid him. But the staff fought on, even when they were so weakened that they could scarce drag themselves along. The Nursing Sisters worked like heroes; they were indeed the backbone of the unit at this crisis. At one time-I have this on the authority of their late O.C., Lieutenant-Colonel Williams-no less than seventeen out of the twenty- 


\section{WAR STORY OF THE C.A.M.C.}

eight were suffering from the disease. In fact, while at Mudros, ninety-five per cent. of the personnelnineteen out of every twenty-developed acute enteritis, mostly of the amœbic variety. When things were at their worst, and there seemed no hope of obtaining invalid supplies and aid for the sick nurses, when the A.D.M.S. could afford no aid, the Navy gallantly came to the rescue, and Captain Pitts, R.N., in charge of the mother ship for the Torpedo section, which was stationed in Mudros harbour, with great kindliness kept the nurses supplied with good food, and what by now had become delicacies, oatmeal, good flour and the like. His help will never be forgotten by the unit. The Nursing Sisters, it need scarce be said, employed much of it for feeding their patients, and rapidly the condition of the more serious cases was ameliorated.

In her report for October, Matron Charleson writes: "The food question is still a difficult one ; these gastro-intestinal cases need farinaceous food, and this is evidently most difficult to procure. Consequently their convalescence is slow, but, like all the Tommies, they never complain, and thoroughly appreciate the Sisters, whose every effort is on their behalf, even to the extent of buying 'Rolled Oats' at exorbitant prices from local dealers, so that Tommy may have porridge for breakfast. The Australians are wonderful fellows, such physique and so unconquerable. ... The last breath of one of these brave lads was a loud order: 'Fall in!'-and then followed the awful silence of death."

With the beginning of autumn there were occasional serious storms. Thus, on September I5th, the plain, or shallow valley, became suddenly a 264 


\section{THE STATIONARY HOSPITALS}

watercourse, a flood some ten inches in depth pouring through many of the tents, to the serious damage of the light and low bamboo Egyptian cots with which they were equipped. On October 8th, during the night, another severe storm brought about the collapse of four of the Sisters' tents. Certain huts of the Alwyn type were in the course of erection by the engineers near by ; these were commandeered, and for the rest of their stay in Mudros -and, in fact, during the remainder of their stay in the East-the Nursing Sisters of this unit were comfortably and properly housed.

With the beginning of October there was an increase in the number of cases of dysentery admitted from Gallipoli, and this of a more resistant type, eighty per cent. being of the amœbic variety; as the month wore on, the bacillary form of the disease became more prominent.

Lieutenant-Colonel McKee* had carried on to the last moment, and when he took to bed his condition was so grave that his life was despaired of. On October I8th he was invalided to England on board the Aquitania. It was the better part of a year before he recovered sound health. Major E. J. Williams assumed command in his place. Yet other officers were invalided to England: Major H. S. Munroe, Captains G. M. Foster and Creighton.

By now the sanitary condition of the camp was greatly improved. Impressed by the strain upon the staff caused by the carriage of each bedpan to the latrines at the outer boundary of the Hospital, Major Williams had devised a practical method of

* For his services Lientenant-Colonel McKee was awarded the C.M.G. He is now O.C. the Canadian Special Hospital for Eye, Ear, Nose and Throat cases at Westcliffe, Folkestone. 


\section{WAR STORY OF THE C.A.M.C.}

dealing with this matter in the form of a "sanitary box latrine," with cover to keep away the flies. These boxes were placed at the end of each row of tents or wards, and were so arranged that both the dejecta and the bedpans were thoroughly disinfected.* This proved itself so useful that it came subsequently into general employment in the hospitals at Salonika.

In November, with the absence of vegetables and continued employment of canned and preserved foods, scurvy began to show itself among the troops at Gallipoli, and so to be admitted into Hospital, and with this there appeared occasional cases of the closely allied condition, beriberi. At the end of this month there was a period of intense cold, with snow and rain. As a result, in one week some four hundred cases of frost-bite were admitted from the peninsula, twelve cases so severe as to demand amputation of the foot, while about three hundred toes needed amputation.

Orders were received to expand to one thousand beds, pending the evacuation of Suvla Bay. Happily that evacuation was so thoroughly organized that no casualties occurred. The same satisfactory note is recorded in connection with the evacuation of the peninsula some four weeks later. The unit itself evacuated Lemnos on January 3Ist, I9r6. To sum up its activities during the stay at Mudros, it may be said that in addition to a very large out-patient clinic, some 6,300 cases were treated in the Hospital wards between August 23rd and January 3ist. Save for the frost-bite cases the work of the unit had been almost wholly medical. It speaks volumes for the efficiency of the unit

* See Journal of the R.A.M.C., 29: 1917: 117. 


\section{THE STATIONARY HOSPITALS}

that, despite the fact that most of the patients arrived as physical wrecks, and, as Matron Charleson expresses it, "very, very ill," the death-rate was singularly low. During the month of October it is reported as being 0.07 per cent. !

\section{2nd Canadian Stationąy Hospital}

When Major D. Bentley brought the I5th Field Ambulance from Sarnia, Ontario, to Valcartier, it there was utilized in the first place to staff No. 2 Camp Hospital, collecting the sick of the Camp and evacuating them to hospitals in Quebec city. When next the order came to attach General and Stationary Hospitals to the First Contingent, the other ranks of this Camp Hospital became the other ranks of No. 2 Canadian Stationary Hospital, under officers also drawn from Ontario, but in the main from the Ottawa district. The O.C., Lieutenant-Colonel A. T. Shillington, and Major F. McK. Bell had both of them been on the staff of St. Luke's Hospital in that city; the Adjutant, Captain C. A. Young, on the staff of the Ottawa General Hospital. Two of the nine officers came from Toronto, one, Major H. C. S. Elliott, from Coburg. The only officer not an Ontario man was the Quartermaster, Captain T. S. Walker, from Prince Edward Island.

It was this unit that was given the honour of being the first unit of the First Contingent to reach French soil, and that eventually found itself becoming established at Le Touquet, the O.C. having been given the choice of this and three other sites by the Boulogne Base.

Le Touquet, some few miles beyond Etaples and on the outskirts of the small but very fashionable 


\section{WAR STORY OF THE C.A.M.C.}

watering-place, Paris Plage, had before the war been well known to golf enthusiasts as possessing on its sand dunes the finest and best laid out golf course on the Continent of Europe, with a spacious Golf Club House, and in its immediate neighbourhood a small and cheerful Hôtel $d u$ Golf and several villas occupied season after season by enthusiasts of the game. The owner of the hotel, Mr. Stoneham, gave it over with great goodwill, and, what is more, donated an operating table for the purposes of the unit. The Royal Engineers made the necessary structural alterations to the hotel; the Officers were installed in " Robinson Villa," the Nursing Sisters billeted in a most luxurious villa belonging to a Roumanian noble, the orderlies in the Golf Club. By this means accommodation was secured for four hundred patients. The unit arrived on 27 th November, I9I4. The furniture had been removed and stored by the proprietor, but bedding, sheets and kitchen utensils were left in the building for the use of the Hospital, which in a few days was ready to take in patients, receiving a first convoy of II5 on $4^{\text {th }}$ December, the majority suffering from "trench feet," the others with slight wounds. Other convoys followed in rapid succession, and in three weeks the Hospital was operating at full capacity, under the administration of the A.D.M.S. Boulogne. Later, in r9r5, when the Etaples district was made into a district Hospital area, it came under Colonel Carr, A.D.M.S. Etaples.

Friends of the Hospital had provided money and gifts of various orders. Red Cross supplies came from friends in the United States; the New Brunswick Daughters of the Empire afforded a fund 


\section{THE STATIONARY HOSPITALS}

through which additional technical equipment was secured; other gifts of money permitted the- O.C. to build an operating-room and rooms for the $\mathrm{X}$-ray Department, and to obtain operating-room furniture and electric heaters for the wards, whereby the food might be served warm.

For the admission and evacuation of patients fourteen motor ambulances from the British Red Cross Society were attached to the unit, the patients detraining at Étaples, some four miles away.

Besides receiving convoys, the Hospital also received sick from the local area. In this connection special note must be made of the Dental Department, under Captain (now Major) W. Bentley.

Whether the teeth of those in the old country are stronger and need less attention, or, what from their appearance seems more probable, whether even when badly decayed they give less pain, the nervous organization of their possessors being less highly strung ; or whether, again, the freer, more democratic life in America has endowed the dentist with a better social position, and so, in general, a more capable set of men take up dentistry for their life work-whatever the cause this is very obvious, both that the Canadian Hospital units arrived overseas far better equipped both in dental officers and apparatus than did the British units, and also that wherever they were stationed, whether like Captain Neely with a Casualty Clearing Station, like Captain Bentley with a Stationary Hospital, or Captain Stevenson and LieutenantColonel Gow with a General Hospital, whether in France, Egypt or Salonika the Canadian dental officers immediately obtained an enormous vogue. Patients flocked to them from surrounding units. 


\section{WAR STORY OF THE C.A.M.C.}

The Canadian dentists were the only ones in the Salonika area, and to them came all ranks, from Generals on the Staff downwards. The King of Serbia placed himself in the hands of LieutenantColonel G. Gow, of the 4th General Hospital, decorated him with the Order of the "White Eagle," gave the anæsthetist, Captain H. J. Shields, C.A.M.C., the Order of St. Sava, and the hospital orderlies, T. O. and A. W. Jones, C.A.D.C., and Corporal A. W. Smith, C.A.M.C., medals of the Crown Prince's Household.

Thus it was that Captain Bentley, of No. 2 Stationary Hospital, rapidly developed a large outdoor clinic, patients coming to him from regimental and other units stationed at Étaples, four miles away.

From the military point of view, the deficiency of the Dental Service in the British Army is closely associated with the painfully imperfect organization of the dental profession in Great Britain. In Canada, with a population of a little over $7,000,000$, at the I9II census there were over 2,000 dentists registered, or one dentist to 3,300 of the population. This, it is true, is behind the United States, which at the I9I2 census had one dentist to every 2,365 of the population.* Great Britain possesses only 5,600 registered dentists. Admitting that

* For these figures $I$ am indebted to a paper by Wallace Seccombe, D.D.S. in Oral Health, Toronto, $7: 1917: 402$, to which Colonel J. A. Armstrong, Director of Dental Service, Canadian Overseas Forces, was so good as to direct my attention. In this paper Dr. Seccombe gives the results of a census of dentists and dental students of the Dominion, which he was directed to make by the National Service Board of Canada. Ontario in 1912, with a population of 2,000,000, had one dentist to each 2,238 ; Quebec, with a population of $2,000,000$, only one dentist to every 6,126 . 


\section{THE STATIONARY HOSPITALS}

there are many thousand unregistered members of the profession, the British Army cannot call upon these unlicensed members and give them official recognition and promotion. As a result, there is not a sufficiency of qualified dentists in Great Britain for civil and military needs. The British soldier suffers from the lack of proper organization of the profession. 


\section{CHAPTER XIV}

OTHER MEDICAL UNITS ON THE LINES OF COMMUNICATION

\section{No. I Casualty Clearing Station}

IN Chapter IV. we described the establishment of No. I Canadian Casualty Clearing Station in Fort Gassion on the outskirts of Aire. Here this unit remained from March, I9I5, until January, I9I6.

To quote Lieutenant-Colonel S. L. Ford, C.M.G., its Commanding Officer: "Before the present war the most advanced medical unit in the evacuation zone was called a Clearing Hospital, but it was soon seen that the name was hardly appropriate. The immense number of sick and wounded which it was called upon to handle in a very limited time seemed to take away from it the character of a hospital, and the name 'Casualty Clearing Station' came into use; and although the stationary phase of operations... has (from time to time) somewhat developed the hospital idea in the Clearing Station, still its chief function remains the rapid evacuation of cases." It was originally a Line of Communications unit, under the I.G.C. ; but, as the war progressed, it was seen to occupy a more advanced position than had been anticipated, and was, for convenience of administration, placed under the direct control of the D.M.S. of the Army as Army Troops. 


\section{OTHER MEDICAL UNITS}

At the beginning of the war the C.C.S. had no transport attached to it, if we except one riding horse per officer. Later, these were withdrawn, and three three-ton motor lorries were detailed for duty with six Army Service Corps drivers. The establishment was further strengthened, first, by the allotment of from seven to nine nursing sisters, whose advent added greatly to the efficiency of the unit; next, by the attachment of an interpreter, three chaplains and a dental surgeon with assistant. Throughout I9I5 the dental officer at No. I Canadian C.C.S. was the most sought after of all its officers, serving all the British units around Aire.

It has to be admitted that the unit found itself at Aire further removed from the Front than it would have liked; nor did its historic housing in Fort Gassion compensate for this relative remoteness. The result was that the Clearing Stations further forward obtained the greater number of cases, and that, save at periods of stress, few of the graver conditions of wounds were admitted to No. I.

After Neuve Chapelle and the Second Battle of Ypres there ensued a quiet period, devoted to placing the old fortress prison in apple-pie order. Rooms and passages that had been dingy glowed under whitewash, paint and active scrubbing, and the unit made a reputation for itself for thoroughness and efficiency.

All associated with No. I Canadian C.C.S. took it as a personal honour when suddenly one afternoon, at the end of October, Surgeon-General W. G. Macpherson, D.D.G.M.S., appeared at the Clearing Station and selected one of the brightest of its nursing sisters, Sister V. A. Tremaine, for 


\section{WAR STORY OF THE C.A.M.C.}

immediate personal attendance upon His Majesty. In the course of a detailed inspection of the Imperial troops along the Flanders Front, His Majesty was conducting a review of the battalions and other units of one of the armies in the neighbourhood of Bethune, when, his horse slipping upon the soil rendered greasy by autumnal rains, fell, and, falling, rolled over heavily upon His Majesty. But for the softness of the ground the results would have been fatal. As it was, His Majesty was seriously crushed. $\mathrm{He}$ was without delay conveyed by motor to a château a little distance out of Aire, where His Majesty had already been staying during his tour, there being no adequate accommodation in the region where he had been injured. A second nursing sister was also selected by Surgeon-General W. G. Macpherson, Sister E. K. Ward, Q.A.I.M.N.S. Territorials, who at the time was doing transport duty on a hospital barge which was passing through Aire at the time of the King's accident. At the château the King was given all the care that the foremost members of the profession overseas, medical and surgical, could afford, with the result that in four days His Majesty was so far recovered as to be able to stand the journey to London.

The two nurses were in attendance upon His Majesty through the journey, and remained in nursing charge of the Royal patient at Buckingham Palace until his convalescence was so far advanced that their services were no longer necessary. Of those quiet days of His Majesty's recovery, this may without indiscretion be said: that Sister Tremaine's most vivid memories are those of the simple happy life of Their Majesties and their 


\section{OTHER MEDICAL UNITS}

children. She found herself in a pleasant English home.

On the day upon which Sister Tremaine relinquished her charge, His Majesty personally presented her with the M.V.O. Badge, together with a further personal gift of an exquisite brooch in gold and enamel, set with diamonds, while $\mathrm{Her}$ Majesty the Queen gave her autograph copies of the Royal photographs. In the New Year's Honours List in I916 Sister Tremaine received the Royal Red Cross.*

\section{No. 5 (Canadian) Mobile Laboratory}

The primary idea of the Mobile Laboratory was, as its name implies, that it should be so equipped that its apparatus could without difficulty be packed up and transported, following the advance of the Army, the laboratory to serve the bacteriological and sanitary needs of an Army Corps at the Front. Events, however, were stronger than plans laid in advance. During the earlier years of the war our troops were on the defensive. It is true that the different Army Corps changed their places along the line not infrequently, and that the mobile laboratories might have remained attached to their respective corps and have moved with them. But this was not to the advantage of the Service. Rapidly these laboratories became of first importance with respect to the bacteriological and chemical

* Nursing Sister Tremaine comes from an English family settled for long years in Quebec City, at least two members of which are officers in the C.E.F. She joined the Army Nursing Service in the spring of 1914 ; in 1916 she was appointed matron of the I.O.D.E. Hospital for Officers in London, and in 1917 matron of Granville Canadian Special Hospital, Buxton. 


\section{WAR STORY OF THE C.A.M.C.}

study of the water-supply of the areas in which they found themselves, and the epidemiology and general sanitation of those areas. It made for efficiency to maintain in the different districts a nucleus of trained men, experts familiar with the special conditions there, rather than to move such officers to other districts and introduce another set of experts, who would take months to attain the same intimate knowledge of local conditions. This argument might not have appealed to everyone, but when, to crown all, the travelling motor laboratories which had been most ingeniously devised to carry out the idea of mobility, proved themselves incapable of withstanding the stresses and strains of the pave roads of Flanders, and the mud of those roads which were not pavés, their springs giving way and their axles breaking on account of the excessive overlay, then all recognized the virtue of making the mobile laboratories as stationary as possible. It was thus that No. 5 (Canadian) Mobile Laboratory was stationed for long months, first at Merville and then at Bailleul, largely irrespective of the movements of the Canadian Ist Division or Army Corps.

The need for sanitary and bacteriological experts at the Front is very great. Not merely has the health of the troops in the trenches to be controlled, and some centre has to be established where rapid bacteriological diagnoses can be made of suspect cases and suspect carriers of epidemic disease, butand this is of even greater importance-the health conditions of the broad belt of country immediately behind the lines have to be controlled. A greater number of men are in this belt than are in the trenches: they are billeted in the towns, 


\section{OTHER MEDICAL UNITS}

villages, isolated farmhouses and hutments scattered through the belt. The civic life of the belt is largely disorganized : most of the inhabitants have left, particularly the wealthier leaders of the community; the usual civic activities are arrested. The Army has to take upon itself civic duties, and becomes responsible for the sanitation of the district, assuming control of such matters as roadmending, water-supply, sewage disposal, even down to notification and quarantine of cases of infectious disease in the civil population that remains. It cannot depend upon municipal laboratories to make analyses and reports: all this work has to be taken over by its mobile laboratories. To run these laboratories it needs expert hygienists, analysts and bacteriologists. Now experts possessing the proper qualifications are at all times few and far between. The Imperial authorities, therefore, gladly seized the opportunity to ask the Canadians to afford such a unit out of the personnel of the Ist Division, and realizing fully the duties before them, the D.M.S. chose for this unit three thoroughly competent officers.

At the very beginning of the war the Minister of Militia determined to avail himself at Valcartier of the services of one who, while not a medical graduate, had made a name for himself as a sanitarian at Toronto, more particularly in connection with the purification of the water-supply of that city. Not being a medical man, there were difficulties in attaching Mr. G. G. Nasmith to the Army Medical Service. The Minister surmounted these by creating a new service, the "Canadian Army Hydrological Corps and Advisers on Sanitation". (September Ioth, IgI4), and in this Mr. 


\section{WAR STORY OF THE C.A.M.C.}

Nasmith was enrolled as Lieutenant-Colonel and Dr. R. E. Wodehouse,* of Port Arthur, as Major. In the later months of IgI4 Captains F. B. Bowman, $\uparrow$ A. M. Cleghorn and F. A. Wallyn were added to the corps. When, therefore, the British authorities asked for the establishment of this new unit at the Front, indicating that the laboratory would have to deal with matters of hygiene and water-supply, as well as with matters epidemiological and bacteriological, this appeared to be the position in which Lieutenant-Colonel Nasmith's special knowledge could be utilized to the best advantage. $\mathrm{He}$, therefore, was placed in command of No. 5 (Canadian) Mobile Laboratory, and to his staff were appointed Captain A. Rankin, Professor of Pathology in the University of Alberta, a trained epidemiologist, who had spent some years as adviser in hygiene and epidemiology at Bangkok, Siam, and Captain A. W. M. Ellis, one of the most brilliant of the younger graduates of Toronto University, and at the beginning of the war a member of the staff of the Hospital of the Rockefeller Institute, New York. Both were on the staff of No. I General Hospital, and had been actively engaged upon the study of the outbreak of cerebrospinal fever at Salisbury Plain.

It was an interesting and thoroughly expert combination, and rapidly it made its influence felt at the Front. These officers, with three N.C.O.'s

* Who became O.C. Sanitary Section, Ist Canadian Division. Now Lieutenant-Colonel, O.C. Canadian Convalescent Hospital at Bear Wood Park, Wokingham.

$\dagger$ Now Major, late O.C. Canadian General Laboratory, Folkestone; later attached to the Italian Expeditionary Force as O.C. a Mobile Laboratory, now Pathologist attached to.D.M.S., L. of C., France. 


\section{OTHER MEDICAL UNITS}

and seven men, left Southampton for France on March 2Ist, I9I5, and on the 26th found themselves located outside the Canadian area at Merville, a bright little country town lying between Aire and St. Estaire, some eight and a half miles to the south-west of Bailleul. Here they were given excellent quarters in the Hotel de Ville, a spacious room, twenty-seven by forty-seven feet, well lighted, with seven large windows, provided with gas and water-a spacious eighteenth-century room which might have been built for laboratory purposes. From the D.M.S. Ist Army (General Macpherson) downwards, everybody helped them. The O.C. records in his War Diary: "Could not say too much for the courteous and kind way in which all the British officers have treated us."

On the 3oth their equipment arrived; on the 3Ist they were ready for work, and cerebro-spinal contacts were being attended to bacteriologically, and suspected diphtheria throats were swabbed. At first they served the $4^{\text {th }}$ Army Corps and the Canadian Division; soon they were given the hygienic and bacteriological work of the Ist Army, and before the end of June that of the area north of the Aire-La Bassée Canal was turned over to them,* together with the general bacteriological work of the Indian Corps. $\dagger$

Their work had a wide scope. Besides the routine work of a clinical laboratory-analyses and reports upon blood, sputa, and other body fluids, and dejecta, and examinations for the detection of causative agents of various infectious diseases-

* Circular Memorandum No. 4, D.M.S. ist Army, of June 23rd, 19r5.

$\dagger$ Circular Memorandum No. I, D.M.S. Ist Army, of June 7 th, 1915 . 


\section{WAR STORY OF THE C.A.M.C.}

and of a pathological laboratory, with the performance of autopsies when needed for neighbouring Casualty Clearing Stations and reports upon surgical material, they were responsible for reports upon the identification and strength of chemicals supplied to the troops in the area, on materials in connection with cases of suspected poisoning, on the efficacy of gas masks and helmets, on poison gases, on the chemical and bacteriological analysis of milk and water. They became, in fact, a general utility laboratory.

We have already, in Chapter IV., referred to the part played by Lieutenant-Colonel Nasmith in the detection of the first poison gas. A more constant study was that of the water-supply of the area. That supply was almost all from wells, and in this low-lying Flanders country almost all the wells are contaminated. Of forty-four sources examined during June, I9I5, ninety-three per cent. showed the presence of B. coli in one cc. of water. Now Bacillus coli inhabits the internal tract of cattle as well as of man, but when in a farmyard the privy is as near to the shallow well as is the dung heap, it is not exactly safe to suppose that these and other contaminating microbes are derived only from harmless cattle. Such water had to be sterilized. There had been an extensive outbreak of typhoid among the civilian population in Flanders in the autumn of I9I4. Lieutenant-Colonel Amyot tells me that there were some eight thousand cases, with two thousand deaths. With widespread inoculation the epidemic had come to an end, and in the spring and summer of I9I5 the disease had become relatively uncommon. But that the water might be responsible for summer diarrhœa is shown 


\section{OTHER MEDICAL UNITS}

by the following :* "In the Division the unit was supplied with boiling water, which was allowed to cool in biscuit tins. On the return of the men from the trenches one day recently the water was found to be still hot, and more water was therefore drawn from the well used as a source of supply, and added to the hot water to cool it. Twenty-five men used this water, and next day thirteen developed diarrhœa. This is a concrete case of what must be happening daily." The method of chlorination employed $\dagger$ was found, as already noted (p. 222), to be quite efficacious-when employed. The diary of the laboratory during I9I5 notes repeatedly that not a few of the watei-carts in that area, judging from the bacteriological results, escaped chlorination.

When the Indian Corps came into the area Captain Rankin was given charge of an investigation of the malarial cases. By far the larger number of positive cases were found to be of the ordinary tertian variety, less than four per cent. were of the more severe æstivo-autumnal form. A century ago malaria was rife in Flanders. It is generally held that the main cause of the failure of the ill-fated Walcheren Expedition in 1809 was the wholesale infection of our troops with ague. The question arose as to whether the same conditions prevailed as, for example, in the Fen districts of Cambridgeshire. This was another region, once intensely malarial, from which the disease

* Report of O.C. No. 5 Canadian Mobile Laboratory to D.M.S. Canadians for June, 1915.

$\uparrow$ In the Journal of the Royal Army Medical Corps for 1910 Nasmith and Graham had described a method of chlorination of water for army purposes which was the basis of that in use. 


\section{WAR STORY OF THE C.A.M.C.}

had vanished, and this, as Professor Nuttall had pointed out, notwithstanding the fact that the mosquito, Anopheles maculipennis, which is the most frequent cause of conveyance of the disease from one individual to another, is still present in fair abundance. As a matter of fact, Captain Rankin, aided by Lieutenant-Colonel Swale Evans, I.M.S., and other Indian Medical Officers, determined the continued presence in Flanders of at least two anopheline mosquitoes and potential malaria carriers, A. maculipennis and $A$. bifurcatus. And in July the first case of malaria was reported occurring in a private of a Scottish regiment who had not been out of Scotland before the war. Malaria is unknown in Scotland. By the end of the year Captain Rankin had collected thirteen similar cases. Malaria in the Tropics occupies the same position as does tuberculosis in the temperate zones. The question, therefore, arose as to whether the presence of the Indian troops, having among them numerous men actively infected with the malarial organism, in an anopheles infested region would lead to a wholesale spread of the disease among the British and Dominion troops, and so, later, to Great Britain, Canada and Australia. Captain Rankin answered this in the negative, and the experience of the last two years has shown that he was fully justified.*

Another special research conducted by this officer $\dagger$ was in combination with Captain G. H. Hunt, of the Imperial Service, upon the new disease which has come to be known as Trench fever.

* See Lancet, 1916 : I. : 1079.

$\dagger$ Intermittent fever of obscure origin occurring among British soldiers in France._Lancet, November 20th, 1915. 


\section{OTHER MEDICAL UNITS}

Save as recognizing that here was a very definite disease entity, like the many other observers who have spent long months studing the condition by bacteriological methods, these officers " drew blank." After three years of careful study and the employment of every known method of research, we are still in the dark as to the cause of Trench fever, save that it is clearly a louse-borne disease.

Simultaneously Captain Ellis carried forward the investigation begun at Salisbury Plain upon the micro-organism of cerebro-spinal fever. Cases of this most dangerous disease occurred from time to time among the troops in the area; but by immediate removal of the cases and rigorous isolation of contacts, the disease was prevented from spreading, and was kept under thorough control, so that despite the many thousands of men living in close contact in the area from April to January Ist, only seventeen cases were diagnosed, in fourteen of which the meningococcus was isolated and grown, while of I3I contacts examined, all save four were found negative. As a matter of fact, it was found that so open and healthy was their life, that men in the trenches did not develop the disease. The few cases occurred in billets behind the lines, and there, as at Salisbury Plain, it was evidently a matter not of house or hutment infection, but of conveyance through the intermediation of drinking vessels in refreshment booths and estaminets.

The failure of Flexner's and other anti-meningococcus serum to arrest the disease at Salisbury and elsewhere in England since the beginning of the war, had been very striking. In previous epidemics the use of this serum had materially 


\section{WAR STORY OF THE C.A.M.C.}

reduced the death-rate. There were the alternatives either that the cultures of meningococci used to produce the serum had in the course of years lost their virulence and other properties, so that when inoculated into animals they set up no adequate reaction, and no adequate discharge of protective substances into the blood, so that the blood serum gained from the inoculated animals was no longer capable of destroying the meningococci when injected into the patient suffering from the disease; or, on the other hand, it might be that in the Army cases we dealt with another order or strain of meningococcus, which was not influenced by the serum produced by inoculating animals with the original New York or other meningococci of previous epidemics. Recent observations at the Rockefeller Institute had con= clusively shown that there exist at least four strains of the organism (pneumococcus) associated with acute lobar pneumonia. Did the same condition of affairs obtain in association with cerebrospinal fever? It was this problem that Captain Ellis set himself to answer. The work required the exact study of as many cultures from different cases and laboratories in England and France as he could obtain, and a long series of delicate observations upon guinea-pigs and animals of the laboratory. To carry on such work just behind the Front within the radius of heavy gun activity, with bombs dropping from time to time from overhead and disturbing the laboratory, with laboratory supplies uncertain, and routine work a first consideration, all this increased the difficulty of the task. It is to the credit of Captain Ellis that notwithstanding all these hindrances, he was able, in December, 


\section{OTHER MEDICAL UNITS}

I9I5, to publish an important paper,* establishing the existence of two main types or strains of meningococci. All of the sixty-four organisms isolated from as many different cases of the disease occurring among the troops in England and France fell into one or the other of his two classes. Almost simultaneously appeared a paper by Lieutenant-Colonel Gordon, R.A.M.C., in which from a similar study of thirty-two growths from the cerebro-spinal fluid of those affected with the disease he was able to differentiate four types. Of these, eighty-four per cent. belong to Types I. and II., corresponding with Captain Ellis's two types. It has been found that by recognizing the particular type or-strain of meningococcus present in a case, and then using the serum gained from animals inoculated with that particular strain, or, more practically, by using a polyvalent serum-i.e., a serum obtained from an animal inoculated with all four strainsthe number of recoveries has been materially increased.

I have dealt with these matters in some little detail in order to demonstrate that the C.A.M.C. has not merely been content to accomplish thoroughly the routine care and treatment of the sick and wounded, but has realized its duty in contributing to medical advance. There are, I know, those inclined to the idea that the only duty of Medical Officers in a great war like the present is to care for the immediate needs of the invalid soldier. There is no time, say they, for the refinements of research, of research which (as in the

* A classification of meningococci based on group agglutination with monovalent immune serum.-British Medical Journal, 1915, ii., 881 , December 15th, and Journal of the R.A.M.C., 26: 1916: 64 . 
case of Trench fever here quoted) may, as well as not, lead-nowhere. Where, it may be answered, would the Imperial Army have been but for the laboratory workers of the last quarter of a century ? The research upon enteric fever and the typhoid bacillus alone has saved to Britain and Canada thousands and tens of thousands of soldiers. Each one of the investigations here described has been accomplished by men engaged in routine work, has been over and above their regulation duties, has dealt with the actual problems of the .war and war medicine, has been designed in order to afford greater knowledge of, and greater mastery over, the diseases affecting the troops, for the greater well-being of the soldier. Research is essential for the successful conduct of the war against disease.

\section{The Sanitary Section}

Here, properly, the good work of the Sanitary Section of the rst Canadian Division should be recorded; but, upon second thoughts, it is seen more appropriate to deal with it in the next volume, for I9I6, and that because the advances made, while begun in I9I5, did not bear their full fruit until the following year. As a matter of fact, some of the more important accomplishments of the section have already been referred to in Chapter XI. 


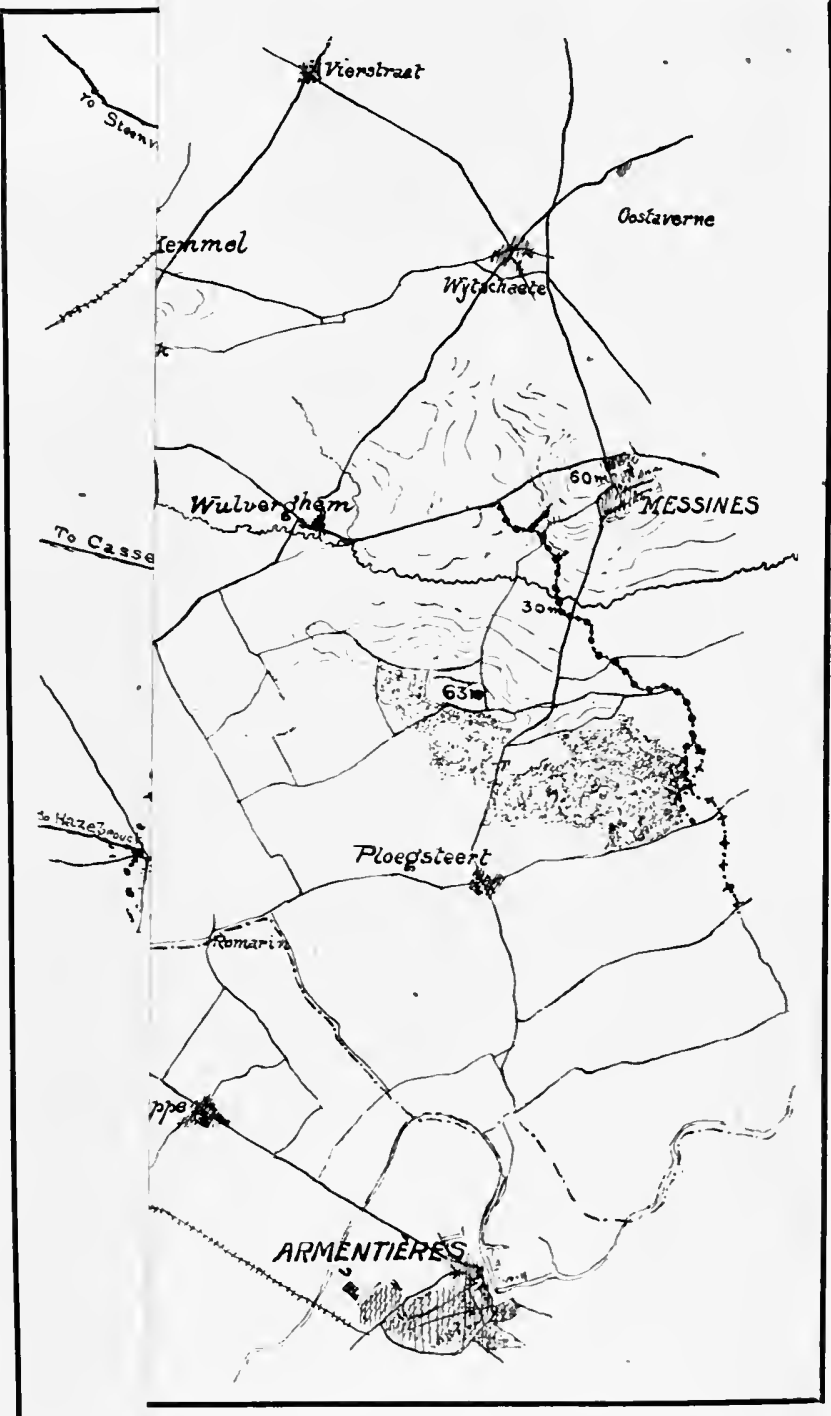

[ To face p. 288. 

PRINTED AT

TIR OHAPEL RIVER PRASS, KINGSTON, SURREY. 

. 



\section{PLEASE do NOT REMOVE \\ CARDS OR SLIPS FROM THIS POCKET}

\section{UNIVERSITY OF TORONTO LIBRARY}


